GRACIONE PICANÇO RIBEIRO

OPERAÇÃO OTIMIZADA DO SISTEMA ADUTOR METROPOLITANO
UTILIZANDO ALGORITMOS GENÉTICOS.
ESTUDO DE CASO:

SAM LESTE DA REGIÃO METROPOLITANA DE SÃO PAULO (R.M.S.P.)

Tese apresentada à Escola Politécnica da Universidade de São Paulo, para obtenção do Título de Doutor em Engenharia Civil. 
GRACIONE PICANÇO RIBEIRO

\section{OPERAÇÃO OTIMIZADA DO SISTEMA ADUTOR METROPOLITANO UTILIZANDO ALGORITMOS GENÉTICOS. \\ ESTUDO DE CASO: SAM LESTE DA REGIÃO METROPOLITANA DE SÃO \\ PAULO (R.M.S.P.)}

Tese apresentada à Escola Politécnica da Universidade de São Paulo, para obtenção do Título de Doutor em Engenharia Civil.

Área de concentração: Engenharia Hidráulica.

Orientador: Prof. ${ }^{0}$ Dr. Kamel Zahed Filho 
Este exemplar foi revisado e alterado em relação à versão original, sob responsabilidade única do autor e com a anuência de seu orientador.

São Paulo, de novembro de 2005.

Assinatura do autor

Assinatura do orientador

Ribeiro, Gracione Picanço

Operação otimizada do sistema adutor metropolitano utilizando algoritmos genéticos: estudo de caso: SAM Leste da Região Metropolitana de São Paulo / G.P. Ribeiro. -- ed.rev. -São Paulo, 2005.

$239 \mathrm{p}$.

Tese (Doutorado) - Escola Politécnica da Universidade de São Paulo. Departamento de Engenharia Hidráulica e Sanitária.

1.Adutoras (Operação; Otimização) - São Paulo (SP) 2.Algoritmos genéticos I.Universidade de São Paulo. Escola

Politécnica. Departamento de Engenharia Hidráulica e Sanitária II.t. 
Ao meu esposo Kildare e à nossa filha Sabrina, pelos momentos de abdicação, apoio, compreensão e amor. 


\section{AGRADECIMENTOS}

À Deus e Nossa Senhora, por tudo e pela realização deste trabalho.

Ao meu querido Kildare, esposo amoroso, presente e grande fortaleza nos momentos difíceis e companheiro nas alegrias, com nossa pequena Sabrina.

Aos meus pais, irmãos por todo o apoio, em particular minha mãe D.Graciete, pelas orações e todo amor e meus primos Hudson e Nilson, pela ajuda nas simulações.

Aos meus sogros e cunhados, pela compreensão e apoio.

Ao Prof. ${ }^{\circ}$ Dr. Kamel Zahed Filho, orientador, amigo, conselheiro e grande professor, pelos anos de convivência, ensinamentos e paciência, que muito contribuiu para meu crescimento pessoal e intelectual.

À Prof. ${ }^{\mathrm{a}}$ Dr ${ }^{\mathrm{a}}$. Luisa Fernanda Ribeiro Reis, pelas muitas dúvidas solucionadas na concepção do código-fonte do modelo otimizador e pela amizade.

Ao Prof. ${ }^{o}$ Dr. Rubem La Laina Porto e Prof. ${ }^{a}$ Dr $^{a}$. Mônica Porto, pela grande ajuda e apoio durante todo curso.

Ao Prof. Dr. Dragan Savic, da Exeter University, pelos pelas dúvidas solucionadas via e-mail.

Ao colega André Schardong, pela amizade e inestimável ajuda da edição do código-fonte.

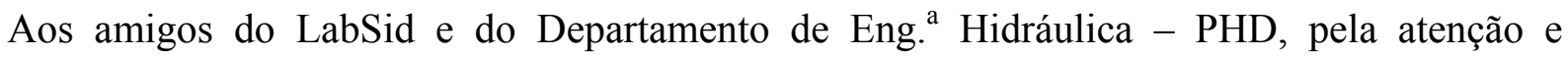
amizade dispensados.

Ao Tecnólogo Luiz Henrique do Nascimento, encarregado do Centro de Controle Operacional da Sabesp, pela atenção dispensada em todas as visitas técnicas e informações sobre o Sistema Adutor Metropolitano.

Ao Eng. ${ }^{0}$ Celso Haguiuda da Divisão de Consumo de Energia e Automação da Sabesp, pelas diversas informações sobre os equipamentos de bombeamento da área de estudo.

À colega M.Sc.Eng. ${ }^{\text {a }}$ Viviana Borges, do Departamento de Desenvolvimento Operacional da Produção e Divisão de Processos da Sabesp, pelas muitas informações sobre a área de estudo e o modelo Epanet.

À colega M.Sc. Eng. ${ }^{\text {a }}$ Sissy Elker Abe Iamasaki, pela ajuda na correção do abstract e pela amizade. 
À Companhia de Saneamento Básico do Estado de São Paulo (SABESP), na pessoa do Eng. ${ }^{\circ}$ Alexandre Tassoni, por permitir o acesso aos dados operacionais e ao Centro de Controle Operacional.

À Escola Politécnica da Universidade de São Paulo, por toda a infra-estrutura e conhecimentos fornecidos.

À Coordenação de Aperfeiçoamento de Pessoal de Nível Superior (CAPES), pelo fornecimento da bolsa de estudos durante a vigência do curso.

Aos demais professores e colegas, pelos conhecimentos divididos e ajuda durante todo o trabalho.

A todos aqueles que direta ou indiretamente contribuíram para o desenvolvimento desta tese, o meu muito obrigada. 
"Toda verdade é fácil de entender uma vez descoberta. O ponto é descobri-la". 


\section{RESUMO}

RIBEIRO, G.P. Operação otimizada do sistema adutor metropolitano utilizando algoritmos genéticos. estudo de caso: SAM Leste da Região Metropolitana de São Paulo (R.M.S.P.). 2005. 239p. Tese (Doutorado) - Escola Politécnica, Universidade de São Paulo, São Paulo, 2005.

O presente trabalho apresenta um algoritmo de otimização que utiliza a técnica dos Algoritmos Genéticos (AG's), associado a um sistema SCADA (Supervisory Control and Data Acquisition), ao simulador de rede Epanet 2.0 (ROSSMAN, 2000) e a registros históricos de demandas, considerados como previsão perfeita. $\mathrm{O}$ algoritmo foi aplicado para otimizar em tempo real, a operação dos reservatórios, minimizando os custos de consumo de energia elétrica pelos boosters e estações elevatórias do sistema SAM Leste, pertencente ao Sistema Adutor Metropolitano (SAM) da Região Metropolitana de São Paulo (RMSP). Foram analisados seis cenários otimizados, representativos das diversas combinações de coeficientes aplicados à função de fitness, tamanhos da população, número de gerações, probabilidades de cruzamento e mutação verificadas, apresentando cenários eficientes de esquemas de acionamento de bombas e estratégias de operação dos reservatórios pelo modelo otimizador. Para utilização em tempo real, os parâmetros dos AG's, devem ser definidos cautelosamente, conferindo aos AG's maior eficiência e rapidez na obtenção das soluções ótimas. Os AG's apresentaram bom desempenho com relação à qualidade das soluções operacionais propostas, considerando que o SAM Leste é um sistema grande, complexo e com muitas limitações e restrições operacionais.

Palavras-chave: Otimização. Operação de redes de água. Algoritmos genéticos. 


\begin{abstract}
RIBEIRO, G.P. Optimized operation of metropolitan mains system using genetic algorithms. Case study: East Metropolitan Mains System of Metropolitan Region of São Paulo (M.R.S.P.). 2005. 239p. Thesis (Doctoral) - Escola Politécnica, Universidade de São Paulo, São Paulo, 2005.
\end{abstract}

This work proposes an optimization algorithm, using the Genetic Algorithms (GA's) method, associated at SCOA, the Sabesp's monitoring system, hydraulics simulator Epanet 2.0 (ROSSMAN, 2000) and a water demand records, considered as perfect forecasting, verified the GA's application to optimize in real-time, the reservoirs operation and to minimize electrical energy consumption costs by East Metropolitan Mains System of Metropolitan Region of São Paulo (M.R.S.P.) boosters. Were examined six optimized representatives options of several weights combinations applied of fitness function, population sizes, generations number, crossover and mutation probabilities investigated, proposing pump schedules and reservoirs operations strategies efficient scenery's, by optimization model. To be used in real-time, GA's parameters must be carefully defined, to let more effective and fast to obtain optimal solutions. The GA's presented good performance about operational solutions quality proposed, considering the large size, complexity and operational limitation of East Metropolitan Mains System.

Keywords: Optimization. Water networks. Genetic Algorithms. 


\section{LISTAS DE ILUSTRAÇÕES}

Figura 2.1 - Esquema de Definição de Políticas Operacionais.............................................. 49

Figura 2.2 - Diagrama de uma função ou processo que é otimizado..................................... 60

Figura 2.3 - Categorias de algoritmos de otimização ........................................................ 61

Figura 3.1 - Representação Gráfica do Ambiente de AG's .................................................. 83

Figura 3.2 - Representação codificada de um cromossomo ou solução ................................. 83

Figura 3.3 - Espaços de Codificação e de Solução.................................................................. 85

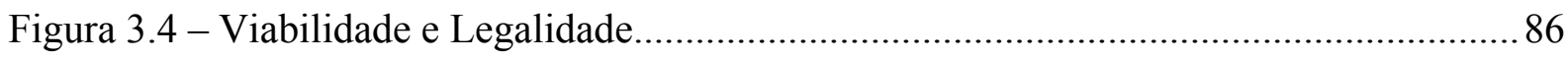

Figura 3.5 - Mapeamento de cromossomos para possíveis soluções ..................................... 87

Figura 3.6 - Funcionamento de Algoritmo Genético Básico ............................................... 90

Figura 3.7 - Seleção em um espaço regular de amostragem após cruzamento e mutação .......98

Figura 3.8 - Espaço aumentado de amostragem ................................................................ 99

Figura 3.9 - Esquema ilustrativo de cruzamento de um ponto ........................................ 105

Figura 3.10 - Esquema ilustrativo de cruzamento de dois pontos ..................................... 106

Figura 3.11 - Esquema ilustrativo de mutação uniforme .................................................... 109

Figura 3.12 - Ilustração da localização dos descendentes gerados pelas combinações linear, relacionada (affine) e convexa, em um espaço bidimensional. ........................ 115

Figura 3.13 - Mutação tipo creep ............................................................................. 118

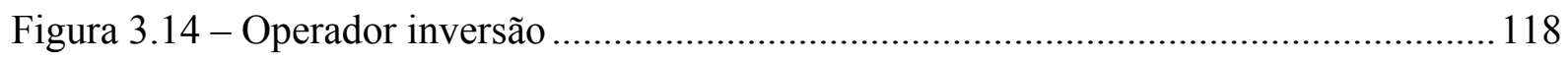

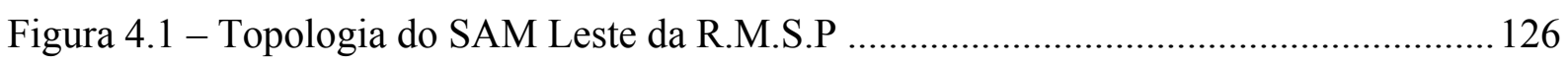

Figura 4.2 - Topologia do SAM Leste no modelo Epanet 2.0 .......................................... 127

Figura 4.3 - Fluxograma do Programa Otimizador.......................................................... 147

Figura 4.4 - Curvas de Consumo dos reservatórios e pontos de controle adotados............... 155

Figura 5.1 - Níveis operacionais dos reservatórios setoriais............................................ 163 
Figura 5.2 - Escala de desempenho dos reservatórios

Figura 5.3 - Evolução de FitnessMax, Fitmedio e FitnessMin

Figura 5.4 - Evolução da função de FitnessMin x CustoEE

Figura 5.5 - Comportamento das penalidades PenaNivMax, PenaNivMin e PenaNivIF ...... 176

Figura 5.6 - Comportamento das penalidades PenaMan e PenaNivIF 178

Figura 5.7 - Operação otimizada do Reservatório Guaianazes 180

Figura 5.8 - Operação otimizada do Reservatório Brás Cubas 182

Figura 5.9 - Operação otimizada do Reservatório Suzano 184

Figura 5.10 - Operação otimizada do Reservatório Itaquera . 186

Figura 5.11 - Operação otimizada do Reservatório Ferraz de Vasconcelos. 188

Figura 5.12 - Operação otimizada do Reservatório Poá. 190

Figura 5.13 - Operação otimizada do Reservatório Itaim 192

Figura 5.14 - Operação otimizada do Reservatório Itaquaquecetuba. 194

Figura 5.15 - Operação otimizada do Reservatório São Miguel. 196

Figura 5.16 - Gradientes hidráulicos horários dos cenários de otimização. 198

Figura 5.17 - Percentual de operação dos boosters e estações elevatórias dos cenários otimizados. 200

Figura 5.18 - Esquema de operação da Estação Elevatória Santa Etelvina dos cenários otimizados. 203

Figura 5.19 - Esquema de operação do Booster Passagem Funda Zona Baixa dos cenários otimizados. 204

Figura 5.20 - Esquema de operação do Booster SAM Leste dos cenários otimizados. 205

Figura 5.21 - Esquema de operação do Booster Brás Cubas dos cenários otimizados 208 


\section{LISTAS DE TABELAS}

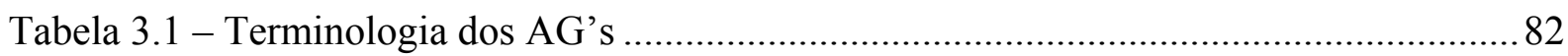

Tabela 4.1 - Resumo das dimensões das adutoras do SAM Leste...................................... 130

Tabela 4.2 - Características Físicas dos Reservatórios do SAM Leste.................................. 131

Tabela 4.3 - Pontos de demanda de água na representação do SAM Leste............................ 131

Tabela 4.4 - Dados cadastrais das válvulas telecomandadas nas entradas dos reservatórios de parte do SAM Leste.

Tabela 4.5 - Dados das curvas características das bombas dos Boosters e Estações Elevatórias 132

Tabela 4.6 - Cotas dos medidores de pressão secundários 133

Tabela 4.7 - Descrição das variáveis de decisão. 145

Tabela 4.8 - Parâmetros dos AG's utilizados no programa .............................................. 148

Tabela 5.1 - Características operacionais dos reservatórios utilizadas nos modelos ............. 165

Tabela 5.2 - Combinação de pesos aplicados à função de fitness ......................................... 167

Tabela 5.3 - Cenários otimizados do SAM Leste pelos AG's ............................................... 169

Tabela 5.4 - Cenários representativos da otimização com AG's ….................................... 170

Tabela 5.5 - Resumo final da otimização via AG's do SAM Leste......................................209 


\section{LISTAS DE SIGLAS E SÍMBOLOS}

AG's = Algoritmos Genéticos;

$\mathrm{AMT}_{i}=$ altura manométrica de cada conjunto moto-bomba $i$, em metros;

AQUANET = modelo de suporte a decisão (PORTO, 2003).

ART* Enterprise $=$ software comercial da Brightware Corporation;

CADIUS = Comitê de Projetos de Sistemas de Distribuição de Água por Computador ;

$\mathrm{CADOP}=$ Cadastro de Dados Operacionais;

CALSIM II = Califórnia Department of Water Resources;

CALVIN = California Value Integrated Network;

$\mathrm{CCO}=$ Centro de Controle Operacional da Sabesp;

$\mathrm{CD}-\mathrm{ROM}=$ compact disk digital para gravação de dados;

consumomed $_{k}=$ consumo médio do reservatório $k$;

CustoEE $=$ Custo normalizado de energia elétrica, adimensional;

CustoMáx $=$ Custo fixo máximo de energia elétrica em unidades monetárias $/ \mathrm{kW} \cdot \mathrm{h}$

CustoReal $=$ Custo real de energia elétrica fornecido pela decisão operacional otimizada pelos AG's;

EBMUD = East Bay Municipal Utilities District;

EPANET 2.0 = modelo simulador público (ROSSMAN, 2000);

ETA's = Estações de Tratamento de Água ;

EXPLORE = modelo híbrido (LEÓN et al., 2000);

FORM = First Order Reliability Method;

GRASP $=$ técnica de otimização

$h=$ horas de simulação;

HEC - PRM = modelo simulador comercial da Hydrologic Engineering Center;

HEC-RESSIM = modelo simulador comercial da Hydrologic Engineering Center; 
Iger = número de gerações a desenvolver;

$i$ = variáveis de decisão do problema;

KYPIPE = modelo simulador $($ WOOD, 1980);

LIMS = Laboratory Information Management System;

ManobraDesej = 3 manobras x número total de válvulas;

ManobraMax = 24 manobras x número total de válvulas;

Manobra $_{i}(h)=$ manobra na válvula com vazão $i$ na hora $h$ igual a 1 se maior que $20 \%$, e zero se menor que $20 \%$;

MSD = modelos de suporte a decisão;

MODSIM = modelo de suporte a decisão (LABADIE et al., 2000);

$\mathrm{N}_{k}(1)=$ nível do reservatório $k$ na primeira hora de simulação, em metros;

$\mathrm{N}_{k}(24)$ = nível do reservatório $k$ no final do período de 24 horas de operação, em metros;

$\mathrm{N}_{k \text { min }}=$ limite baixo operacional do reservatório, em metros;

$\mathrm{N}_{k \max }=$ limite alto operacional do reservatório $k$, em metros;

OASIS = modelo de suporte a decisão da Hydrologics, Inc.);

PI = Programação Inteira;

PL = Programação Linear;

PNL = Programação Não-Linear;

PCRUZ = probabilidade de cruzamento $(\%)$;

PESOS $=$ valores numéricos aplicados às penalidades PenaNivIF, PenaNivMin, PenaNivMax e PenaMan, respectivamente;

PopSize $=$ tamanho da população;

POWERSIM = modelo simulador comercial da Powersim Inc.;

Programação Dinâmica (PD) 
PMUT = probabilidade de mutação $(\%)$;

$\mathrm{Q}_{\mathrm{i}}(h)=$ vazão $i$ aduzida ao reservatório na hora $h, \mathrm{em} \mathrm{l} / \mathrm{s}$;

SABESP = Companhia de Saneamento Básico do Estado de São Paulo;

SCADA = Supervisory Control and Data Acquisition;

SCOA = modelo de monitoramento e aquisição de dados do tipo SCADA;

somademan $(h)=$ soma das manobras de todas as válvulas na hora $h$;

SPU = Seattle Public Utilities;

STELLA = modelo simulador comercial da High Performance Systems;

tarifaP $=$ tarifa no horário de ponta em unidades monetárias $/ \mathrm{kW}$.h do conjunto moto-bomba $i$ pertencente a cada booster ou estação elevatória na hora $h$;

tarifaFP $=$ tarifa no horário fora de ponta em unidades monetárias $/ \mathrm{kW} . \mathrm{h}$ do conjunto motobomba $i$ pertencente a cada booster ou estação elevatória na hora $h$;

$\operatorname{VazRec}_{i}=$ vazão recalcada de cada conjunto moto-bomba $i$ acionado, na hora $h$, em 1/s;

VENSIM = modelo simulador commercial da Ventana Systems, Inc.;

$\phi=$ conjunto dos boosters e estações elevatórias, ligados na hora $h$;

$\phi_{2}=$ conjunto dos reservatórios do sistema;

$\phi_{3}=$ conjunto das vazões nas válvulas de controle de vazão do sistema; 


\section{SUMÁRIO}

RESUMO …

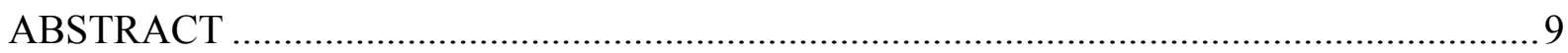

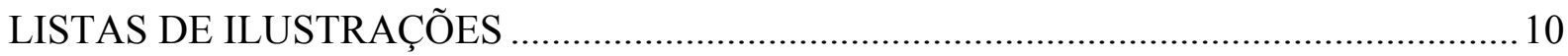

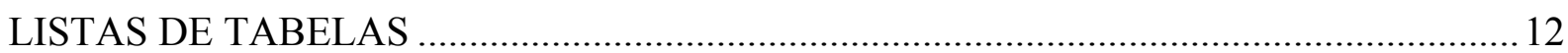

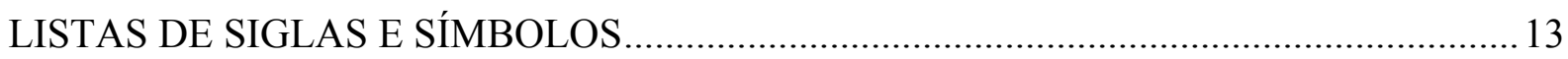

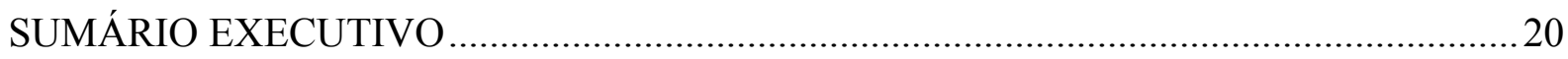

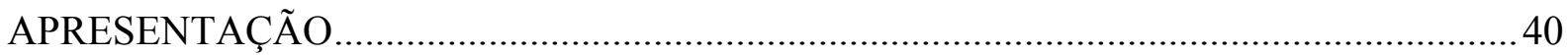

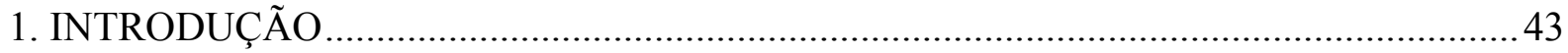

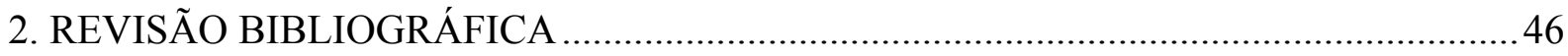

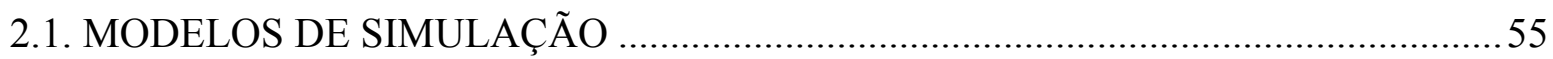

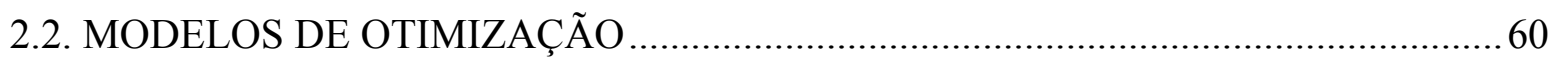

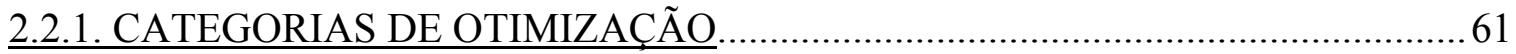

2.3. MODELOS DE PREVISÃO DE DEMANDA ………………………………….......

3. INTRODUÇÃO AOS ALGORITMOS GENÉTICOS ………………………………......... 81

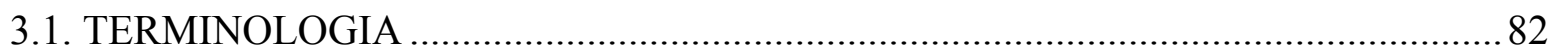

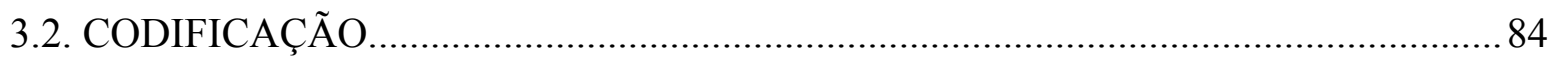

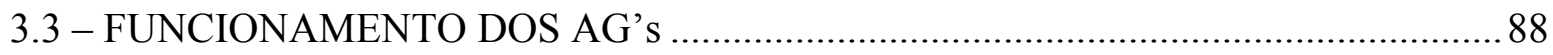

3.4. DIFERENÇAS DOS AG'S EM RELAÇÃO A OUTRAS TÉCNICAS DE

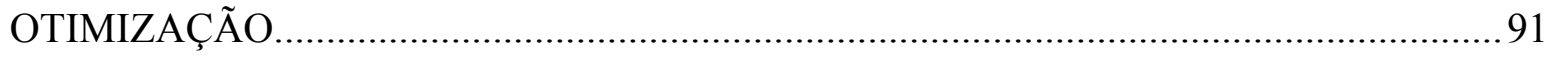

3.5. MAIORES VANTAGENS DOS AG'S EM RELAÇÃO A OUTRAS TÉCNICAS DE

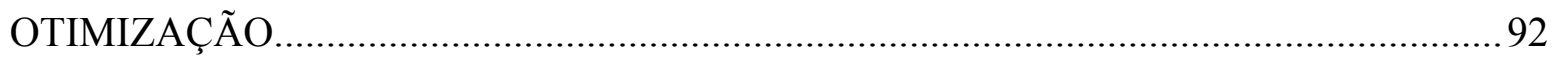

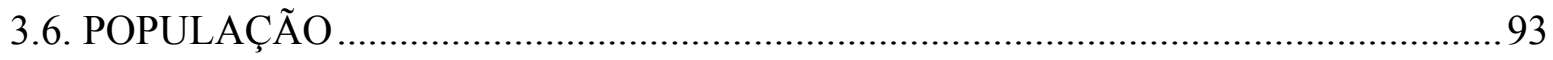

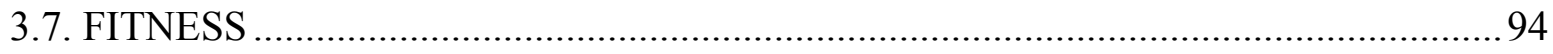

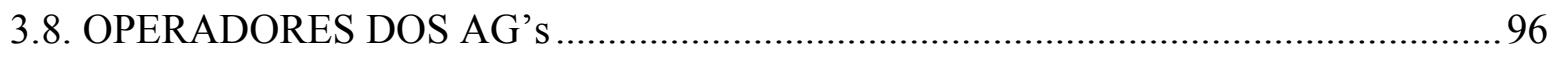




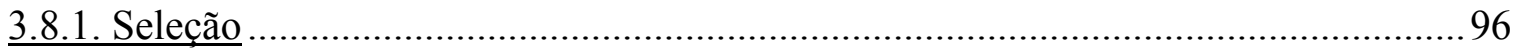

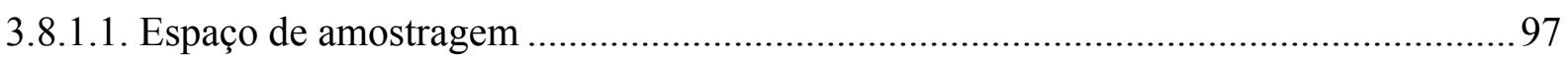

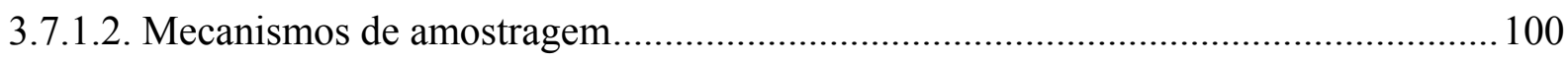

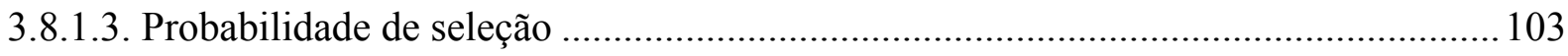

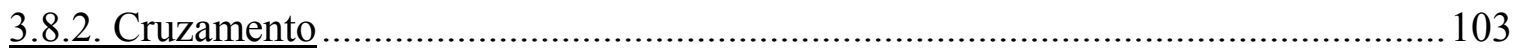

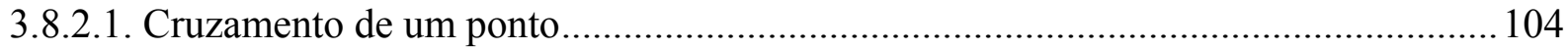

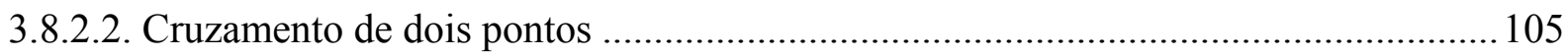

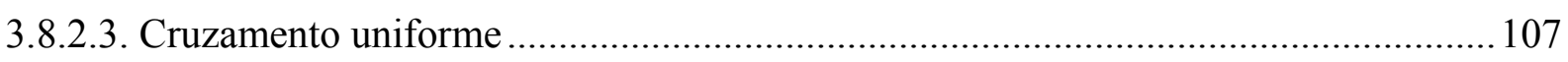

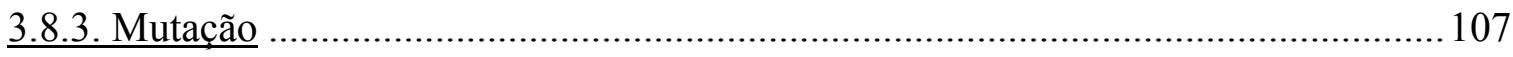

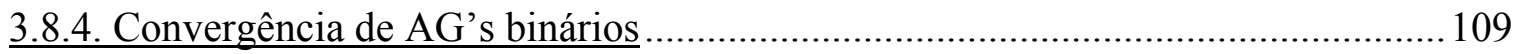

3.9. VARIAÇÕES DOS AG's ……………………………………………………110

3.9.1. Codificação de parâmetros contínuos …………………………………………...... 110

3.9.2. Operadores convencionais para AG's de parâmetros contínuos .....................................112

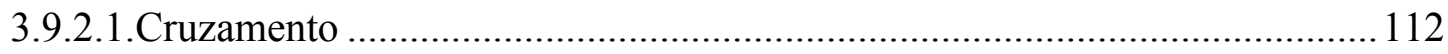

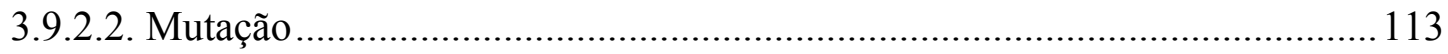

3.9.3. Operadores aritméticos para parâmetros contínuos ........................................................ 114

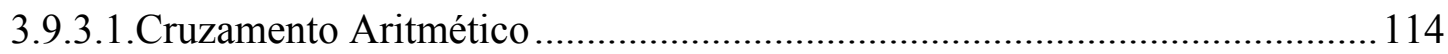

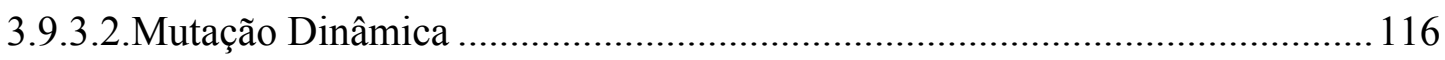

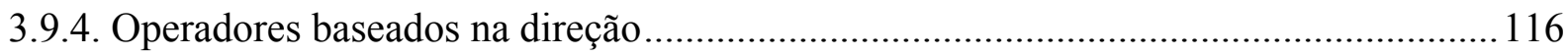

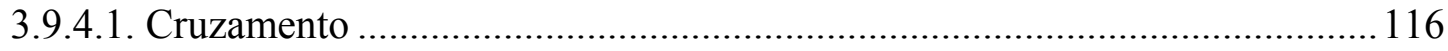

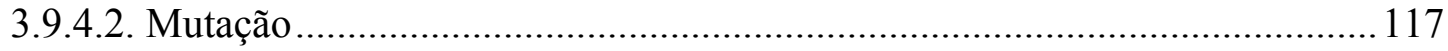

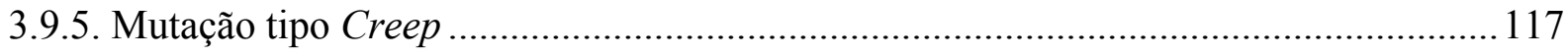

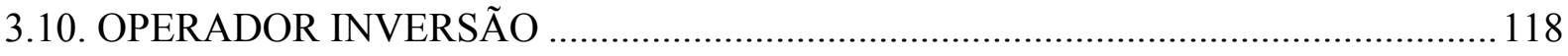

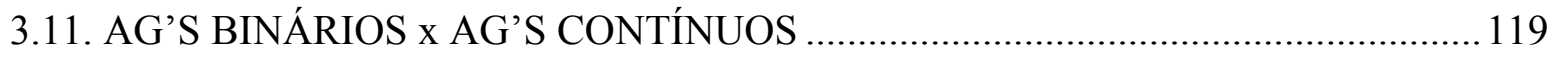

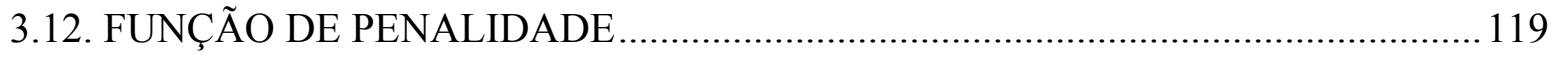


3.12.1. Classificação da função de penalidade 120

3.13. PARÂMETROS DOS AG's 121

4. MATERIAL E MÉTODOS

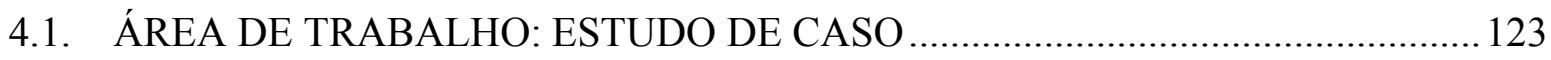

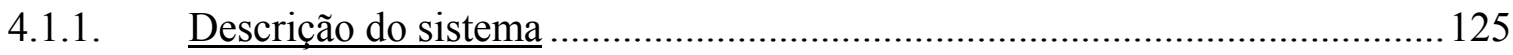

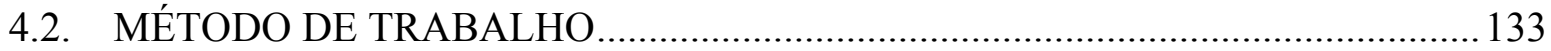

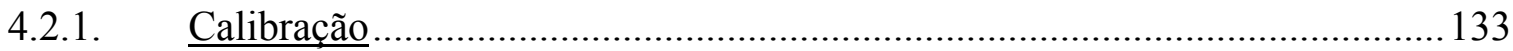

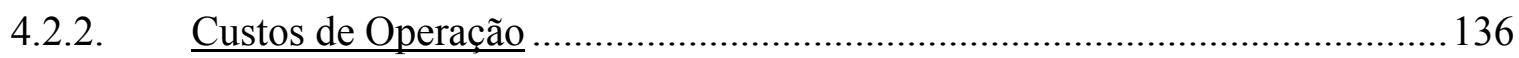

4.2.2.1. Implementação de AG's ao problema de operação do SAM Leste ........................ 136

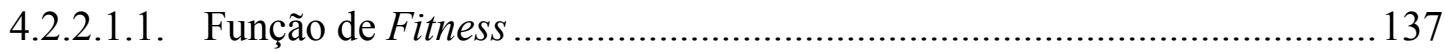

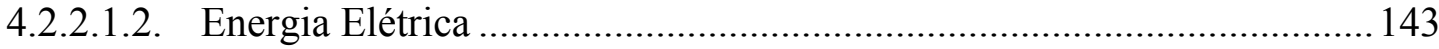

4.2.2.1.3. Variáveis de Decisão ............................................................................... 144

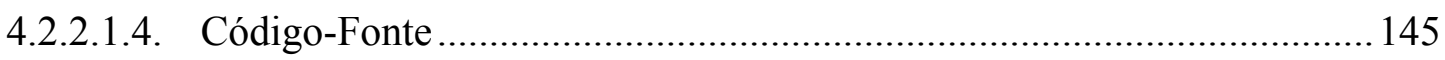

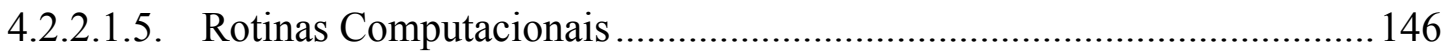

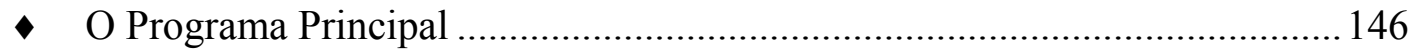

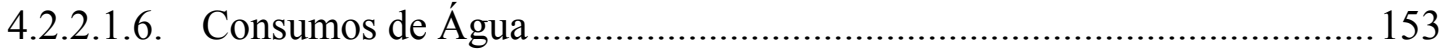

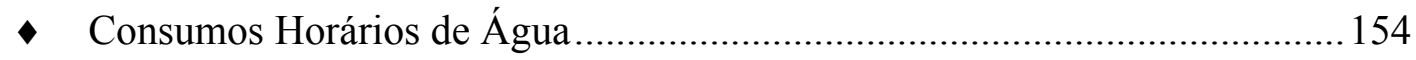

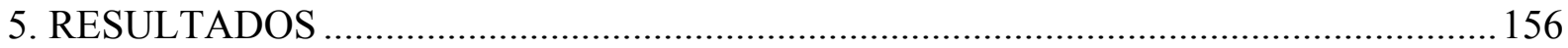

5.1. RESULTADOS DA CALIBRAÇÃO DO MODELO HIDRÁULICO ......................... 156

5.2. ANÁLISE DE SENSIBILIDADE E ÍNDICES UTILIZADOS NO MODELO

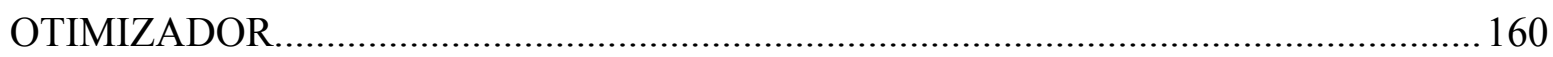

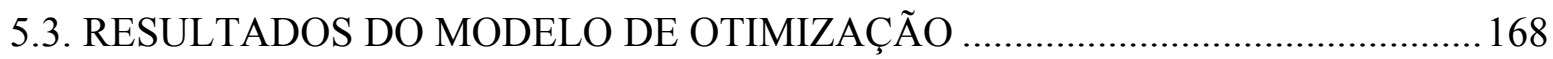

5.3.1. Estratégias ótimas de operação dos reservatórios ................................................. 179

5.3.2. Esquemas otimizados de operação dos boosters e estações elevatórias ................. 199 
5.4. TEMPO DE PROCESSAMENTO COMPUTACIONAL DOS CENÁRIOS DE OTIMIZAÇÃO

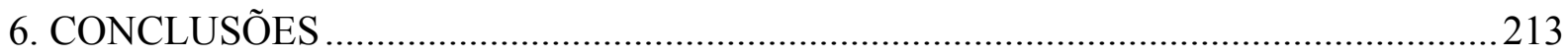

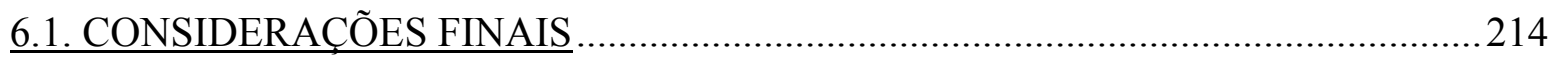

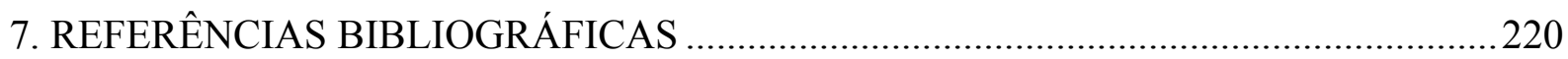

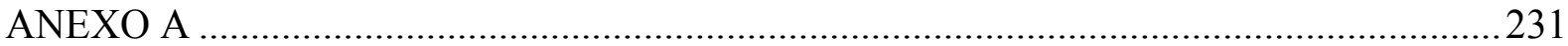

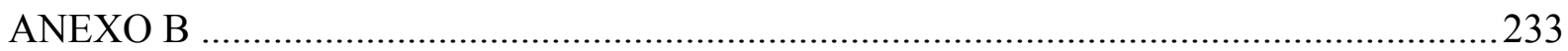


SUMÁRIO EXECUTIVO 


\title{
OPERAÇÃO OTIMIZADA DO SISTEMA ADUTOR METROPOLITANO UTILIZANDO ALGORITMOS GENÉTICOS. ESTUDO DE CASO: SAM LESTE DA REGIÃO METROPOLITANA DE SÃO PAULO (R.M.S.P.)
}

\author{
Gracione Picanço Ribeiro \\ Departamento de Engenharia Hidráulica/ POLI-USP \\ CEP 05508-900 - São Paulo, S.P. - fone: (011)3091-5529 - gracione.ribeiro@poli.usp.br
}

Kamel Zahed Filho

Departamento de Engenharia Hidráulica/ POLI-USP

CEP 05508-900 - São Paulo, S.P. - fone: (011)3091-5168 - kamel@,usp.br

\begin{abstract}
RESUMO
O presente trabalho apresenta um algoritmo de otimização que utiliza a técnica dos Algoritmos Genéticos (AG's), associado a um sistema SCADA (Supervisory Control and Data Acquisition), ao simulador de rede Epanet 2.0 (Rossman, 2000) e a registros históricos de demandas, considerados como previsão perfeita. O algoritmo foi aplicado para otimizar em tempo real, a operação dos reservatórios, minimizando os custos de consumo de energia elétrica pelos boosters e estações elevatórias do sistema SAM Leste, pertencente ao Sistema Adutor Metropolitano (SAM) da Região Metropolitana de São Paulo (RMSP). Foram analisados seis cenários otimizados, representativos das diversas combinações de coeficientes aplicados à função de fitness, tamanho da população, número de gerações, probabilidades de cruzamento e mutação verificadas nas simulações, apresentando cenários eficientes de esquemas de acionamento de bombas e estratégias de operação dos reservatórios pelo modelo otimizador. Para utilização em tempo real, os parâmetros dos AG's, devem ser definidos cautelosamente, conferindo aos AG's maior eficiência e rapidez na obtenção das soluções ótimas. Os AG's apresentaram bom desempenho com relação à qualidade das soluções operacionais propostas, considerando que o SAM Leste é um sistema grande, complexo e com muitas limitações e restrições operacionais.
\end{abstract}

Palavras-chave: Otimização. Operação de redes de água. Algoritmos genéticos.

\section{INTRODUÇÃO}

Atualmente, os sistemas de adução de água das grandes metrópoles, são progressivamente ampliados e submetidos a aumento de demanda, e vêm desta forma, se constituindo em um problema cada vez mais crítico para os gerenciadores que operam esses sistemas. Com o crescimento populacional e a ampliação das áreas a abastecer, a complexidade e dimensões dos sistemas tende a crescer. Considerando seus elementos de adução, reservação, bombeamento, manobras e distribuição, torna-se ainda mais complexo o controle operacional, face às decisões tomadas pelos operadores baseadas na experiência, às situações em que tais decisões são necessárias e à sua repercussão operacional no sistema.
Um exemplo bastante crítico é o da RMSP, que vem apresentando demandas superiores ou muito próximas à oferta, implicando na necessidade de uma operação otimizada para redução de déficits, atendimento à demanda e para adução de água de forma mais racional, uma vez que a capacidade de investimento em obras é limitada, conforme análises de Zahed Filho (1990); Cipparrone (1995); Gambale (2000) e Borges (2003).

A não-linearidade e a complexidade destes cenários fazem com que tecnologias tradicionais disponíveis para o tratamento analítico, como Programação Linear e Não-linear, Programação Dinâmica (Brion e Mays (1991); Pezeshk et al. (1994); Diba (1995); Cipparrone (1995); Watkins e Mckinney (1998), Labadie, (2004)), apresentem 
dificuldades de convergência, com grande tempo de processamento e sem a garantia do ótimo global quando aplicadas.

Dentre as técnicas de otimização disponíveis atualmente, os Algoritmos Genéticos (AG's) têm sido amplamente utilizados desde a sua criação por Holland (1975) nas mais diversas áreas do conhecimento, apresentando-se como uma meta-heurística robusta e poderosa de busca adaptativa, flexível e de fácil implementação, baseada na Teoria da Evolução de Darwin, com resultados significativos, inclusive aplicáveis para esse tipo de problema, dada a complexidade e dimensão do sistema e também, como ferramenta para tomada de decisões inerentes às situações e ambientes de um cenário desse porte.

Resta ainda a dúvida quanto à velocidade dos AG's na convergência e na definição da solução ótima, para avaliar sua adequação à operação em tempo real.

Assim, face ao cenário descrito, a presente pesquisa faz-se necessária, com a criação de algoritmo adequado às dimensões $e$ complexidades de uma situação real.

Para a avaliação dos Algoritmos Genéticos (AG's) como ferramenta de otimização de sistemas de abastecimento em tempo real, esta pesquisa tem como objetivo a criação de um programa de computador que otimize a operação do SAM Leste do SAM.

\section{REVISÃO BIBLIOGRÁFICA}

Muitos pesquisadores têm se voltado para a otimização da operação de reservatórios em sistemas de abastecimento público, considerando inclusive os problemas relativos à otimização dos custos de projeto e às tecnologias e modelos de otimização de objetivo único e multiobjetivo, disponíveis no meio científico.

De acordo com Zahed Filho (1990), a operação de sistemas em tempo real, é uma tarefa bastante complexa, que vêm recebendo atenção especial já há algum tempo, face à necessidade de garantir confiabilidade no atendimento dos serviços, economia no uso de equipamentos (energia elétrica e manutenção) e retardamento de investimento para expansão do sistema, mesmo que ainda seja pouco pesquisada.

Mais recentemente, Francato (2002) comenta que com a possibilidade de execução de modelos matemáticos complexos em computadores pessoais, os profissionais podem detalhar os sistemas de maneira mais precisa, ficando mais próximo o equacionamento matemático da situação física real. Desse modo, pode-se dedicar mais tempo à análise da consistência dos resultados, estudos de novas formulações, rearranjo dos sistemas, medidas de reabilitação, etc.

Yeh (1985) e Wurbs (1993) têm notado um "vazio" contínuo entre as implementações desenvolvidas teoricamente e o mundo real. As possíveis disparidades, para Labadie (2004), são de que muitos operadores de sistemas são céticos quanto a modelos que proponham a substituição de seus julgamentos e prescrição de estratégias e sensibilidade "mais confortável" com o uso de modelos de simulação existentes. Limitações computacionais de software e hardware no passado, requereram simplificações e aproximações que operadores são indispostos a aceitar.

$\mathrm{Na}$ literatura, é possível observar uma quantidade considerável de experiências bem sucedidas com modelos de simulação em recursos hídricos (Goulter e Coals, 1986; Goulter e Bouchart, 1990; Fujiwara e Tung, 1991; Pezeshk et al., 1994; Ormsbee e Lansey, 1994; Diba et al., 1995; Luvizzoto Júnior, 1995; Wagner et al., 1998; Sakarya e Mays, 1998; Meier e Barkdoll, 2000; Draper et al., 2003; Labadie, 2004).

Dentre os modelos de simulação podem ser citados o HEC-RESSIM (Hydrologic Engineering Center), STELLA (High Performance Systems), POWERSIM (Powersim Inc.), VENSIM (Ventana Systems, Inc.), KYPIPE (Wood, 1980) e EPANET (Rossman, 2000), os quais têm sido rotineiramente aplicados por muitos anos em agências de desenvolvimento e planejamento de recursos hídricos.

Da mesma forma que os modelos de simulação, os modelos de otimização vêm sendo incorporados de maneira progressiva, juntamente com as técnicas mais utilizadas, a análises de sistemas de abastecimento de água, seja em sua fase de projeto, seja na sua operação diária.

Os trabalhos de otimização em redes hidráulicas, têm diversas aplicações como a minimização de custos de bombeamento de adução a reservatórios (Wardlaw e Sharif, 1999; Ribeiro, G., 2000), minimização das perdas por vazamento em redes de água (Reis, Porto e Chaudhry, 1997), estratégias operacionais para sistemas de reservatórios (Reis e Akutsu, 2002), e principalmente, a operação ótima dos sistemas adutores e de distribuição de água (Simpson et al, 1994; Oliveira e Loucks, 1997; Cui e Kuczera, 2003; Van Zyl, Savic e Walters, 2004).

$\mathrm{Na}$ opinião de Labadie (2004), a situação dos modelos de otimização em relação a sua 
aplicação na solução dos problemas operacionais dos sistemas de abastecimento, na atualidade é:

- Os modelos de otimização são mais complexos matematicamente que modelos de simulação e por isso, mais difíceis de se compreender;

-Os modelos de otimização não incorporam riscos e incertezas;

-A enorme variedade de modelos de otimização criam confusão sobre qual selecionar para uma aplicação em particular; -Alguns métodos de otimização como, por exemplo, a programação dinâmica, freqüentemente necessitam de desenvolvimento de código-fonte customizado e,

-Muitos métodos de otimização podem produzir somente soluções ótimas em vez de produzir regras úteis de operação condicional.

Os modelos de simulação são limitados a descrever o desempenho de um dado sistema (natureza descritiva) e os modelos de otimização procuram automaticamente pela solução ótima (natureza otimizante).

As técnicas de otimização mais utilizadas são as heurísticas e as meta-heurísticas. Segundo Barr et al. (1995), os métodos heurísticos (também chamados algoritmos de aproximação, procedimentos inexatos ou simplesmente heurísticas), vêm do grego "heuriskein" que significa descobrir, é um conjunto de passos bem definidos para identificar rapidamente uma solução de alta qualidade para um problema, onde a solução é um conjunto de valores desconhecidos para o problema e a "qualidade" é definida por um critério ou avaliação métrica padrão.

$\mathrm{Na}$ década de 80 , surgem as metaheurísticas, como a Busca Tabu, Algoritmos Genéticos, Redes Neurais, Simulated Annealing, e GRASP. São exemplos de algoritmos mais complexos, sendo aplicados a problemas com comportamento não-linear e de grandes dimensões.

Labadie (2004) comenta que existem poucas áreas da aplicação de modelos de otimização de história tão rica ou mais diversa quanto a otimização de sistemas de reservatórios. Embora oportunidades para aplicações ao mundo real sejam enormes, atuais implementações permanecem limitadas. $O$ referido autor está convencido que as chaves para o sucesso na implementação de sistemas de reservatórios são: (a) aumentar os níveis de confiança para um envolvimento mais interativo dos decisores no desenvolvimento destes sistemas; (b) pacotes computacionais com melhor desempenho; (c) interface melhorada com os modelos de simulação, os quais os operadores aceitam mais prontamente e, (d) a aplicação das meta-heurísticas é particularmente importante, amplamente adotadas devido sua forte fundamentação científica.

A habilidade dos AG's, analisa Labadie (2004), de ser conectados diretamente a modelos de simulação é uma grande vantagem.

Para Van Zyl, Savic e Walters (2004), o problema de encontrar a estratégia ótima de operação está longe de ser trivial: ambos os custos de eletricidade e demandas da rede podem variar grandemente através de um ciclo típico de operação; níveis mínimos de água devem ser mantidos nos reservatórios para garantir confiabilidade do abastecimento e o número de acionamentos deve ser limitado, no sentido de limitar os custos de manutenção excessivos. Os autores comentam ainda que além dos fatores acima expostos, está 0 fato de que 0 comportamento hidráulico dos sistemas de abastecimento de água é altamente não-linear, tornando a modelagem computacional um processo complexo e de grande consumo de tempo.

Com relação aos modelos previsionais de demanda, houve no Brasil, em 1986, uma tentativa de desenvolvimento de modelo pela Companhia de Saneamento Básico do Estado de São Paulo (SABESP), com apoio de empresa de consultoria, comenta Zahed Filho (1990).

Dentre as tentativas de obter-se um modelo previsor de consumos em tempo real foi a de apresentar uma solução simples e eficaz, baseada no princípio de obtenção de um desvio mínimo entre a vazão de consumo estimada e a observada. Entretanto, face à dificuldade na aquisição de dados, não se obtiveram resultados conclusivos utilizáveis na operação em tempo real.

Francato (2002) comenta que a previsão de demanda é um passo fundamental para que se possa obter uma política operacional do sistema de abastecimento, principalmente para operações em tempo real.

Zahed Filho (1990) propôs um modelo que tinha por objetivo o atendimento dos seguintes requisitos básicos: (a) previsão de resultados compatíveis com desvios aceitáveis de operação, (b) simplicidade de processamento e (c) flexibilidade de implementação de correções. De acordo com o referido autor, é muito mais interessante, atualmente, definir uma regra (hoje subjetiva do operador) do que se alcançar a previsão "perfeita". É necessário que o tempo de processamento de operação do modelo previsor 
seja compatível com intervalos, exigindo modelos simples e rápidos.

$\mathrm{Na}$ análise de Ormesbee e Lansey (1994), a previsão de demanda deve empregar 3 (três) passos: (a) a previsão diária de demanda; (b) a demanda distribuída espacialmente associada aos nós da rede e (c) a distribuição de demanda durante o horizonte de planejamento.

León et. al. (2000) desenvolveram um sistema especialista híbrido chamado EXPLORE para gerenciar o sistema de abastecimento de água de Sevilha, Espanha. No protótipo, utilizou-se o software especialista para aquisição de dados e gerenciamento de regras operacionais $A R T^{*}$ Enterprise (Brightware Corp.). Dentre as dificuldades encontradas, observa-se a dependência das demandas de água, que segundo os autores, é o maior fator incontrolável.

Assim, face ao cenário de escassez crescente dos recursos hídricos e ao acima descrito, mais e mais esforços devem ser feitos no sentido de se obterem subsídios e técnicas, capazes de auxiliar os engenheiros na sua tarefa diária, de utilizar de maneira ótima os recursos hídricos para atendimento das demandas de água, operar os sistemas de abastecimentos de água, e conciliar a disponibilidade do insumo básico, que é a água, com baixos custos e eficiência destes sistemas adutores e seus componentes.

\section{OS ALGORITMOS GENÉTICOS (AG'S)}

Dentre as meta-heurísticas mais consagradas estão os Algoritmos Evolucionários, que são sistemas computacionais de solução de problemas baseados na evolução natural (Holland, 1975; Goldberg, 1987; Gen e Cheng, 1997). A variedade dos Algoritmos Evolucionários desenvolvidos (Programação Evolutiva, Programação Genética, Classificadores Genéticos e Algoritmos Genéticos) oferece uma característica conceitual comum, de simular a evolução de estruturas individuais, através de processos de seleção, mutação e recombinação (cruzamento).

O processo depende do desempenho apresentado pelas estruturas individuais definidas pelo ambiente. Os Algoritmos Genéticos (AG's) são os mais populares dos Algoritmos Evolucionários.

Savic et al. (1997) afirmam que os principais campos de aplicação dos AG's incluem problemas com alto grau de complexidade, propriedades e comportamento não-lineares, mostrando se uma técnica extremamente eficiente quando implementada em problemas de otimização com dimensões significativas, além das características acima ressaltadas, como é o caso da operação dos sistemas adutores de água.

De fato, os AG's têm demonstrado sua capacidade em tratar um grande número de estudos empíricos e analíticos, como por exemplo, aplicações incluindo programação e seqüenciamento, projetos de confiabilidade, programação e rotas de frotas, tecnologia de grupo, organização de layouts e locações, finanças, operação de sistemas de abastecimento elétrico (Miranda et al. 1998), sistemas produtivos e tratamento de resíduos líquidos e sólidos (Chang e Wei, 2000).

Os AG's derivam seu comportamento de uma metáfora de alguns mecanismos da evolução natural, e em essência, consistem em uma população de strings de bits transformada pelos três operadores genéticos: seleção, cruzamento e mutação, durante o processo evolutivo.

Cada cromossomo representa uma solução possível para o problema que está sendo otimizado formado por bits. Cada bit ou grupo de bits, representam o valor de uma variável do problema (gene).

Essas soluções são classificadas em uma função de avaliação, função objetivo ou ainda, função de aptidão (fitness), produzindo os melhores valores ou cenário das melhores soluções. Cada solução é avaliada pela função de aptidão (havendo uma regra para o ambiente) para produzir um valor.

Os AG's operam num processo muito simples: primeiro é gerada aleatoriamente a população inicial, sendo avaliada pela função de aptidão. A seqüência é feita com a criação de uma nova população, aplicando-se o operador evolutivo seleção, com posterior aplicação dos operadores genéticos cruzamento e mutação, até que um critério de parada estabelecido seja atingido.

\section{Seleção de pais}

O operador seleção cria uma nova população (ou geração de indivíduos), pela seleção dos indivíduos mais adaptados da população anterior para a melhor solução. A seleção pode ser estocástica (roleta), determinística (elitismo) e mista, que contém características estocásticas e determinísticas (torneio).

\section{Cruzamento}

A recombinação ou cruzamento é o mecanismo de criação de indivíduos (novas soluções) filhos através da recombinação de indivíduos pais (soluções atuais). É o operador que 
torna os AG's diferentes dos outros algoritmos evolucionários. Geralmente é realizada através da simples permuta ou da combinação de características correspondentes entre soluções pais, sendo que o esquema de permuta mostra-se adequado ao caso de soluções representadas através de código binário, enquanto que 0 da combinação é mais utilizado quando a representação de soluções é do tipo real. É executado com freqüência controlada por uma probabilidade de cruzamento (PCRUZ). Michalewicz (1992) descreve três tipos de cruzamento mais usuais: de um ponto, de dois pontos e uniforme.

\section{Mutação}

A mutação é a sistemática que possibilita a introdução de características genéticas novas às soluções existentes, através da eventual substituição de genes dos indivíduos. Geralmente é realizada bit por bit (no caso de código binário) ou gene por gene (código real), possibilitando que cada bit ou gene seja alterado com uma pequena probabilidade ou taxa $p_{m}$ entre 0.001 e 0.1 , geralmente constante, ou variáveis de acordo com técnicas avançadas de ajuste dinâmico (Reis e Akustu, 2002).

\section{Critérios de parada ou convergência}

Não existe prova matemática de convergência ou qualquer garantia que AG's achem o mínimo global. Após a aplicação dos operadores de recombinação e mutação, a nova população está pronta para a próxima avaliação, e o ciclo se repete até que a condição de finalização seja considerada satisfeita. O critério de finalização mais simples é realizar um determinado número de iterações. Entretanto não se conhece a priori o número de gerações mais apropriado a determinado tipo de problema. Podem ser usados critérios alternativos de convergência baseados no fato de que ou a maioria dos cromossomos é idêntica ou nenhuma melhora significativa no valor da função de aptidão ocorreu para um determinado número de gerações (Reis e Akutsu, 2002).

\section{Configurações dos AGs e escolha dos parâmetros de controle}

A literatura oferece inúmeras possibilidades e configurações para a implementação dos AG's. Deve-se avaliar os objetivos a serem atingidos, de forma a escolher a codificação (binária ou real) mais adequada ao problema, assim como o tamanho da população, o tamanho do string, tipo de operadores de seleção, cruzamento e mutação a serem utilizados, assim como suas probabilidades.

\section{Vantagens associadas aos AGs}

-AG's não necessitam de exigências matemáticas de implementação em relação aos problemas de otimização. Devido à sua natureza evolutiva, irão buscar por soluções sem levar em consideração as características do problema, externas às soluções a serem obtidas.

-AG's podem manipular qualquer tipo de função de aptidão e restrições (linear ou não linear), definidas em espaços de busca de parâmetros discretos, contínuos ou mistos; -AG's fornecem flexibilidade para hibridização com heurísticas dependentes de domínio para fazer uma implementação eficiente para um problema específico;

-Tratam com grande número de parâmetros a serem determinados, podendo ser aplicados a problemas de grande dimensão numérica;

-São bem ajustados para processamento paralelo, ou seja, microprocessadores que buscam as soluções ótimas paralelamente e simultaneamente e, -Otimizam funções com superfícies complexas, podendo saltar de um mínimo local (característica de uma meta-heurística) para outra região de soluções viáveis.

\section{ÁREA DE TRABALHO: Estudo de caso}

A Companhia de Saneamento Básico do Estado de São Paulo (SABESP), opera o Sistema Adutor Metropolitano de São Paulo (SAM), controlando a partir do Centro de Controle da Operação (CCO), com sistema SCOA (do tipo SCADA), a adução dos oito sistemas produtores com 8 (oito) ETA's que produzem aproximadamente $63 \mathrm{~m}^{3} / \mathrm{s}$ de água, para cerca de 19 milhões de habitantes em uma área de $8.500 \mathrm{Km}^{2}$. Possui 125 reservatórios setoriais e pontos de entrega, atendendo a demanda de consumos de água de $2,12 \times 10^{6} \mathrm{~m}^{3} / \mathrm{dia}$.

\section{Descrição do sistema}

A pesquisa proposta foi aplicada a uma alça de adução de água tratada, o SAM Leste, cuja metodologia possa ser aplicável para todo SAM. O sistema em estudo possui 10 reservatórios (incluindo o Reservatório de Distribuição na saída 
da ETA Taiaçupeba, abastecida pelo Sistema Alto Tietê), $75.6 \mathrm{~km}$ de adutoras, 1 estação elevatória, 3 boosters e 6 válvulas de controle de pressão e 9 de controle de vazão, com uma demanda total de 6.439 litros/s, para o dia típico estudado. A topologia do SAM Leste pode ser visualizada pela Figura 1.

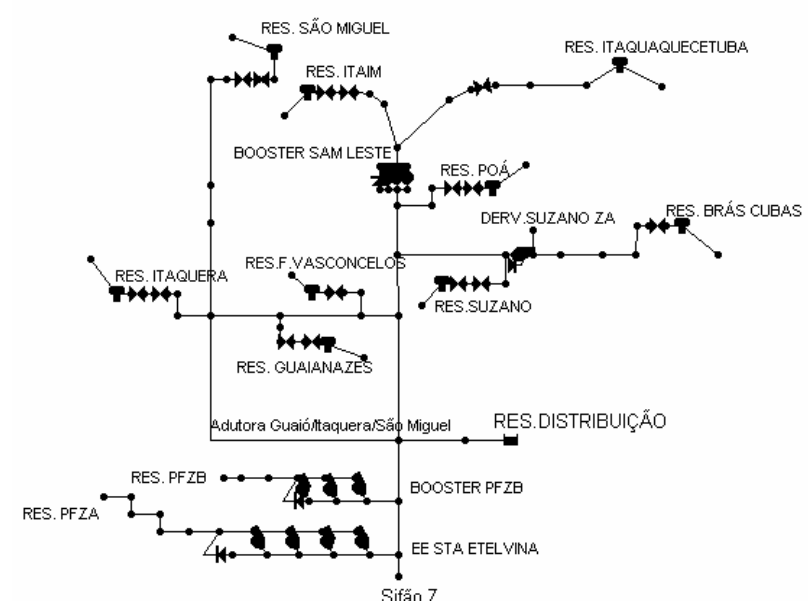

Fig.1 SAM Leste da RMSP

Legenda:

W = válvula de controle de vazão ou de pressão;

- = nó de demanda ou conexão;

$\boldsymbol{\Gamma}=$ reservatório setorial;

$\sqcup=$ reservatório de distribuição;

$\bullet$ = adutora ou derivação;

to = by-pass;

= grupo moto-bomba com sucção à esquerda e recalque à direita.

De acordo com Borges (2003), o SAM Leste tem como limites físicos definidos: os Reservatórios Brás Cubas, Itaquaquecetuba, São Miguel, Itaim e Itaquera. Além destes reservatórios, foram considerados como limites os nós de demanda para os Reservatórios Passagem Funda Zona e Zona Baixa, o nó do Sifão 7. Estes nós de demanda além da derivação do Reservatório Suzano para a Zona Alta, foram considerados desta forma por insuficiência de dados cadastrais. A topologia do SAM Leste considerada neste estudo, conforme apresentada na Figura 1, é composta por:
-Reservatórios Guaianazes, Suzano, Itaquera, Poá, Itaim e São Miguel com tubulação de entrada por cima;

- Reservatórios Brás Cubas, Ferraz de Vasconcelos e Itaquaquecetuba com entrada por baixo;

- Reservatório de Distribuição (RD) da Estação de Tratamento de Água Taiaçupeba, que alimenta todo o sistema; -Pontos de demandas sem reservação: Sifão 7, Reservatórios Passagem Funda Zona Alta, Passagem Funda Zona Baixa e Derivação do Reservatório Suzano para Zona Alta;

-Boosters e estações elevatórias, com velocidade de rotação constante: Santa Etelvina com quatro grupos moto-bombas ( 3 operando $x 1$ reserva), Passagem Funda Zona Baixa com três grupos moto-bombas (2 operando $x 1$ reserva), SAM Leste com três grupos moto-bombas (2 operando $x 1$ reserva) e Brás Cubas com um conjunto moto-bomba.

\section{CALIBRAÇÃO}

No desenvolvimento do modelo simulador, optou-se por aplicar, para efeito de calibração do modelo, o simulador hidráulico Epanet 2.0, (Rossman, 2000). Em virtude da opção por considerar como mais significativo em termos de investigação, o período de 24 horas entre as 6:00h da manhã até as 6:00h do dia seguinte, que é quando efetivamente a rede começa a ser solicitada, escolheu-se o período das 6:00h do dia $05 / 05 / 2002$ até às $6: 00 \mathrm{~h}$ do dia 06/05/2002, como dia típico da calibração e otimização.

$\mathrm{Na}$ fase inicial de calibração do modelo simulador hidráulico, foram primeiramente simulados com base nos dados levantados previamente, estados e características dos componentes da rede: os coeficientes de rugosidade, perdas de energia das tubulações, capacidade dos reservatórios e seus níveis mínimos e máximos, status dos equipamentos de bombeamento e suas especificações técnicas, assim como das válvulas, vazões de entrada nos reservatórios, pressões nos nós e curvas de consumos horários.

Nesta fase, a idéia da calibração é reproduzir em regime permanente, a operação do SAM Leste instantaneamente. Para tanto, definiuse como pontos de controle da calibração, os nós imediatamente a montante das válvulas de controle de vazão dos reservatórios, os nós de demanda 
em marcha do Sifão 7 e derivação do Reservatório Suzano para Zona Alta do setor, o nó a montante da sucção do Booster Passagem Funda Zona Baixa e nó de jusante do recalque da Estação Elevatória Santa Etelvina. Nos pontos de controle, são comparadas as pressões instantâneas calculadas pelo simulador hidráulico, com as registradas pelo SCOA.

No segundo momento, em regime estendido, atribuiu-se as demandas médias para cada válvula de controle de vazão, para os trechos com adução por gravidade, até os reservatórios.

No caso dos trechos que são aduzidos com auxílio de bombeamento, majorou-se a demanda média do setor na razão de $24 \mathrm{~h} / 21 \mathrm{~h}$, devido ao fato de ter sido imposto ao modelo através de regras de controle, o desligamento dessas bombas no horário de pico de 3 horas de duração consecutivas, considerado das 17:00 às 20:00h. Este ensaio serviu para verificar se o sistema é perfeitamente otimizável, isto é, se a regra "simples" funcionasse, não haveria necessidade do modelo otimizador.

Após essa fase, verificou-se a possibilidade da área estudada ser controlável e otimizável e que ainda, fosse possível melhorar o desempenho da operação feita pelo CCO da Sabesp, da seguinte forma: após as simulações feitas, a idéia é observar se os reservatórios extravasavam ou esvaziavam e se atendiam ou não às demandas da rede ao longo das horas, impondo-se regras de controle no formato padrão do Epanet 2.0 (Rossman, 2000) acima descritas.

Criou-se então, com base na topologia de estudo já calibrada e validada, um modelo utópico, isto é, um modelo com as dimensões majoradas de seus componentes, mas com vazões derivadas para consumo mantidas, de forma que fosse verificado o comportamento do modelo, caso a capacidade de adução e de reservação fosse superdimensionada.

Como modelo de previsão de demandas, utilizou-se os registros históricos desde 1997, de forma que esses dados foram considerados como uma previsão exata das demandas requeridas pela rede do setor estudado.

Após a validação do modelo real e a criação do modelo utópico, estes foram submetidos à otimização operacional através dos AG's, verificando-se tanto a possibilidade de uma melhoria operacional referente àquela praticada na Sabesp quanto o comportamento dos AG's diante de um modelo real e um modelo com "folga" em seu sistema adutor. Para a otimização da operação, foi mantido o período de $24 \mathrm{~h}$ do dia $05 / 05 / 2002$ às $6: 00 h$ até o dia 06/05/2002, às $6: 00 h$ da manhã.

\section{IMPLEMENTAÇÃO DE AG'S AO PROBLEMA DE OPERAÇÃO DO SAM LESTE}

O modelo de otimização tem interface com o modelo Epanet 2.0 via En2toolkit (Rossman, 2000) e com banco de dados Access do SCOA. Os dados fornecidos pelo modelo de simulação Epanet 2.0 (Rossman, 2000) via toolkit e os registros históricos operacionais do SCOA da Sabesp (registros considerados como previsão perfeita), foram utilizados como dados de entrada para o algoritmo de otimização via técnica dos AG's, para que o próprio algoritmo forneça, pela aplicação dos operadores genéticos e evolucionários: a)Os melhores cenários e regras operacionais, em termos de atendimento de demanda horária, vazão de adução e reservação ótima; b)A estratégia ótima de funcionamento dos equipamentos de bombeamento em relação às tarifas de energia elétrica e ao horário de operação e, c)Quantidade de manobras de abertura/fechamento das válvulas.

\section{Função de Fitness}

Como os AG's são ferramentas aplicáveis à otimização como de busca direta e assim a problemas de otimização combinatoriais, tanto as restrições como os limites operacionais descritos a seguir, serão tratados como penalidades aplicadas à função aptidão (fitness).

No método proposto por Deb (2000), as restrições são manipuladas, utilizando função de fitness ajustável, que depende da população corrente. Assim, desde que as soluções não sejam comparadas em termos tanto do valor da função objetivo quanto da informação da violação da restrição, não há necessidade de qualquer parâmetro de peso explícito. Entretanto, para evitar qualquer tendência de uma restrição em particular, todas são normalizadas.

$\mathrm{Na}$ presente pesquisa, o método proposto por Deb (2000) foi adaptado da seguinte forma:

- Como há a necessidade da informação da violação da restrição, foram utilizados parâmetros de peso explícitos;

- Devido à disparidade de ordem de grandeza do valor das violações entre si, as restrições e inclusive o valor do custo de energia elétrica a ser minimizado, foram normalizados de forma que variassem de 0 a 1 .

Assim, a função de fitness que otimizará a operação do SAM Leste fica estabelecida como a de minimização do custo de energia elétrica e das penalidades de violações, conforme as seguintes expressões: 
O custo do consumo de energia elétrica das bombas ou custo real, em unidades monetárias/h, é expresso pela equação (1):

$$
\begin{aligned}
\text { Custo } \operatorname{Re} a l= & \sum_{h=1}^{24}\left[\sum_{i \in \phi}\left(\text { tarifaP } * \operatorname{Vaz} \operatorname{Re} c^{*} A M T_{i}\right)+\right. \\
& \left.\sum_{i \in \phi}\left(\text { tarifaFP } * \operatorname{Vaz} \operatorname{Re} c_{i} * A M T_{i}\right)\right]
\end{aligned}
$$

Para $\mathrm{h}=1, \ldots, 24$ horas e $\mathrm{i}=1, \ldots, 20$ variáveis. Sendo i = variáveis de decisão do problema; tarifaP = tarifa no horário de ponta em unidades monetárias/kW.h do conjunto moto-bomba $i$ pertencente a cada booster ou estação elevatória na hora $\mathrm{h}$; tarifaFP = tarifa no horário fora de ponta em unidades monetárias/kW.h do conjunto motobomba $i$ pertencente a cada booster ou estação elevatória na hora $h$; $\operatorname{VazRec}_{i}=$ vazão recalcada de cada conjunto moto-bomba $i$ acionado, na hora $h$, em $\mathrm{I} / \mathrm{s} ; \mathrm{AMT}_{\mathrm{i}}=$ altura manométrica de cada conjunto moto-bomba $i$, em metros e $\phi_{1}=$ conjunto dos boosters e estações elevatórias, ligados na hora h;

Para normalizar o custo de energia elétrica, definiu-se ainda o custo mínimo de operação dos boosters como sendo aquele em que todos os conjuntos moto-bombas estivessem desligados no período simulado, com os reservatórios sendo abastecidos por gravidade:

$$
\text { CustoMin }=0
$$

Também foi definido o custo máximo do consumo de energia elétrica destes equipamentos, para efeito de normalização do custo de energia elétrica, como sendo o custo de todas as bombas estarem operando nas 24 horas do dia, com uma vazão recalcada igual ao consumo médio de água. Assim, o custo máximo ficou definido pela equação (3):

\section{CustoMax $=\left(3^{*} \mathrm{AMT}_{\mathrm{i}}{ }^{*}\right.$ consumomed ${ }_{\mathrm{k}}{ }^{*}$ tarifaP $)+$ $\left(21^{*} \mathrm{AMT}_{\mathrm{i}}{ }^{*}\right.$ consumomed ${ }_{\mathrm{k}}{ }^{*}$ tarifaFP $)$}

Onde consumomed $_{\mathrm{k}}=$ consumo médio do reservatório k;

O custo de energia elétrica normalizado é então expresso pela equação (4):
CustoEE $=1-\frac{(\text { CustoMáx }- \text { Custo Re } a l)}{(\text { CustoMáx })}$

onde CustoEE = custo normalizado de energia elétrica, adimensional; CustoMáx = custo fixo máximo de energia elétrica em unidades monetárias/kw.h; CustoReal = custo real de energia elétrica fornecido pela decisão operacional otimizada pelos AG's.

Para que a otimização seja eficiente, as restrições normalizadas impostas na forma de penalidades devem atender às seguintes condições, para que a função de aptidão atinja o mínimo:

(a) atender à demanda horária aduzida para abastecimento do setor mantendo o nível de reservação flutuando entre os limites alto e baixo de operação;

(b) respeitar os limites alto e baixo dos reservatórios durante o período de simulação de 24 horas, estando intrínsecos respeitar os limites de extravasamento e esvaziamento dos reservatórios e,

(c) considerar que o nível final dos reservatórios não pode estar abaixo do nível inicial ao final do período de simulação de 24 horas.

A formulação adotada das restrições é:

-Penalidade de nível final do reservatório k estar abaixo do nível inicial (PenaNivIF):

PenaNivIF $=\sum_{k \in \phi 2}\left[\frac{N_{k}(1)-N_{k}(24)}{N_{k}(1)}\right]$

se $\mathrm{N}_{\mathrm{k}}(24)<\mathrm{N}_{\mathrm{k}}(1)$ ou

PenaNivIF $=0$ se $N_{k}(24) \geq N_{k}(1)$

Onde $\phi_{2}=$ conjunto dos reservatórios do sistema; $\mathrm{N}_{\mathrm{k}}$ $(1)=$ nível do reservatório $k$ na primeira hora de simulação, em metros; $\mathrm{N}_{\mathrm{k}}(24)=$ nível do reservatório $\mathrm{k}$ no final do período de 24 horas de operação, em metros;

- Penalidade de nível do reservatório $\mathrm{k}$ na hora $\mathrm{h}$ estar abaixo do nível mínimo ou limite baixo (PenaNivMin):

$$
\text { PenaNivMin }\left\{\begin{array}{l}
=1 \text { se } N_{k}(h) \leq N_{k} \min \\
=0 \text { se } N k(h)>N k \min
\end{array}\right.
$$


Onde $\mathrm{N}_{\mathrm{k}} \min =$ limite baixo operacional do reservatório k, em metros;

- Penalidade de nível do reservatório $\mathrm{k}$ na hora $\mathrm{h}$ estar acima do nível máximo ou limite alto PenaNivMax):

PenaNivMax $\begin{aligned} & =1 \text { se } N k(h) \geq N k \text { máx } \\ & =0 \text { se } N k(h)<N k \text { máx }\end{aligned}$

Onde $\mathrm{N}_{\mathrm{k}} \max =$ limite alto do reservatório $\mathrm{k}$, em metros;

-Número de manobras nas válvulas que resultem em alterações das vazões aduzidas superiores a 20\%: número de manobras mínimo definido como desejável, é de 3 manobras em $24 \mathrm{~h}$ por cada válvula ( 3 manobras $\times 9$ válvulas $=27$ manobras no total). O número máximo é de 24 manobras por cada válvula (24 manobras x 9 válvulas $=216$ ). Assim, a equação (8) fica:

$$
\text { PENAMAN }=\left[\frac{(\text { somademan }(h)-\text { ManobraDesej })}{(\text { ManobraMax }- \text { ManobraDesej })}\right]
$$

Para

$$
\begin{gathered}
\left\{\begin{array}{l}
\operatorname{Manobra}_{k}(h)=1, \text { se }\left|\frac{\left(Q_{i}(h)-Q_{i}(h-1)\right)}{\text { consumomed }_{k}}\right| \geq 0,2 \\
\operatorname{Manobra}_{k}(h)=1 \text {, se }\left|\frac{\left(Q_{i}(h)-Q_{i}(h-1)\right)}{\text { consumomed }_{k}}\right| \geq 0,2
\end{array}\right. \\
\operatorname{somademan}(h)=\sum_{i \in \phi 3} \sum_{h=1}^{24} \operatorname{Manobra}_{i}(h)
\end{gathered}
$$

Onde ManobraDesej = 3 manobras $\mathrm{x}$ número total de válvulas; ManobraMax $=24$ manobras $x$ número total de válvulas; Manobra $a_{i}(h)=$ manobra na válvula com vazão $i$ na hora $h$ igual a 1 se maior que 20\%, e zero se menor que $20 \%$; somademan $(h)=$ soma das manobras de todas as válvulas na hora $h$; $Q_{i}(h)=$ vazão $i$ aduzida ao reservatório na hora $h$, em I/s; $\phi_{3}=$ conjunto das vazões nas válvulas de controle de vazão do sistema;

Assim, a função objetivo a ser minimizada é expressa detalhadamente pela equação que definirá o fitness das soluções, a função de fitness, conforme a equação (12):
Fitness $=$ Min $($ CustoEE + PenaNivIF + PenaNivMin + PenaNivMax+PenaMan)

Os custos otimizados do sistema serão expressos como o somatório dos custos normalizados de consumo de energia elétrica e das penalidades, para o período de simulação de 24 horas.

\section{Energia Elétrica}

A demanda de energia elétrica corresponde à parcela fixa contratada de potência (em kW), que no caso do SAM Leste é igual à capacidade total instalada em cada estação elevatória ou booster disponibilizada na rede elétrica pela concessionária e desta forma, o seu custo foi desconsiderado na função objetivo por independer das variáveis de decisão.Todas as instalações dos grupos moto-bombas se enquadram na Tarifa Horosazonal Azul, sub-grupo A4, conforme praticado pela empresa Bandeirante, concessionária local. Pelo fato de estarem sendo utilizados os registros dos dias 05 e 06/05/2002, as tarifas de consumo de energia elétrica, consideradas são as do período seco do ano, de Maio a Novembro. Considerou-se como horário de ponta o período das 17:00h às 20:00h, e o fora de ponta, as demais horas do dia. Para o horário de ponta, a tarifa unitária praticada e aplicada no modelo é de $\mathrm{R} \$ 0.186 / \mathrm{kW}$.h e para o horário fora de ponta, R\$ 0.090/kW.h.

\section{Variáveis de decisão}

As variáveis de decisão são as soluções a serem investigadas no modelo de otimização via AG's, que compõem o string de 20 genes (variáveis) das soluções, totalizando 480 características em 24 horas de simulação, sendo 264 variáveis binárias do tipo 0/1 e 216 do tipo real.

\section{Código Fonte}

O código-fonte foi desenvolvido na linguagem Visual Basic versão $6.0 \mathrm{com}$ interfaces para planilhas eletrônicas, banco de dados e gráficos em tempo de execução (programa em execução). O programa principal lê: o módulo de interface para o banco de dados tipo Access, o módulo com a definição dos parâmetros POPSIZE, IGER, PCRUZ e PMUT, a serem utilizados pelos operadores genéticos (cruzamento e mutação), operador evolutivo (seleção) e nas avaliações da função de fitness (os respectivos valores são 
apresentados na Tabela 1). Lê também o módulo da biblioteca de funções (epanet2.dll) da toolkit do simulador Epanet 2.0 (Rossman, 2000).

Tabela 1. Parâmetros dos AG's

\begin{tabular}{|l|c|}
\hline \multicolumn{1}{|c|}{ Parâmetro } & Valores \\
\hline PopSize & 10,200 \\
\hline Iger & $20,40,400$ \\
\hline PCRUZ & $30 \%, 50 \%, 80 \%$ \\
\hline PMUT & $0.2 \%, 0.5 \%, 1.0 \%$ e $10 \%$ \\
\hline \multicolumn{1}{|c|}{ Penalidades } & Pesos \\
\hline PenaNivIF & $0.05,0.10,0.60$ \\
\hline PenaNivMin & $0.10,0.20,0.30$ \\
\hline PenaNivMax & $0.05,0.10$ \\
\hline PenaMan & $0.05,0.10,0.20,0.30$ \\
\hline
\end{tabular}

Os valores dos parâmetros dos AG's utilizados de acordo com a Tabela 1, foram estabelecidos segundo análise de sensibilidade preliminar de utilização do algoritmo. São eles: PopSize = tamanho da população; Iger = número de gerações a desenvolver; $P C R U Z=$ probabilidade de cruzamento (\%); PMUT=probabilidade de mutação (\%); PESOS=valores numéricos aplicados às penalidades PenaNivIF, PenaNivMin, PenaNivMax e PenaMan, respectivamente. Os pesos aplicados às penalidades poderiam ter assumido outros valores conforme opção de investigação. Os valores apresentados na Tabela 1 foram os efetivamente simulados.

\section{Resultados e Discussão Calibração}

Na primeira fase de calibração do modelo Epanet 2.0 (Rossman, 2000), verificou-se com sucesso a reprodução instantânea da operação do CCO da Sabesp em regime permanente, às 18:30h do dia 06/05/2002.

A simulação em período estendido mostrou que no SAM Leste, somente os Reservatórios Guaianazes e Itaquera não atendem às demandas no horário de pico de consumo. O Booster Passagem Funda Zona Baixa e Estação Elevatória Santa Etelvina necessitam de pelo menos um e dois equipamentos operando, respectivamente, para atender às demandas, isto é, quando da imposição da regra de não operação dos grupos moto-bombas no horário de ponta, ocorreu o não atendimento das demandas, já que não é possível vencer o desnível geométrico sem bombeamento. Os demais boosters e reservatórios locais não apresentaram problemas operacionais.
Portanto, o sistema apresenta alguns pontos críticos em sua operação que podem ter melhor desempenho operacional, como é o caso da adutora que abastece os Reservatórios Ferraz de Vasconcelos, Guaianazes e Itaquera com uma regra mais ajustada.

Outro ponto de difícil operação é a adutora que abastece os Reservatórios Itaim e Itaquaquecetuba. Mas neste caso, os reservatórios atendem às demandas setoriais sem extravasar ou esvaziar. A rede restante do sistema SAM Leste apresenta-se na simulação sem problemas de não atendimento às demandas locais.

Pode-se então dizer, com base nos resultados acima comentados, que o sistema é controlável, pois, pequenas alterações operacionais são impactantes na rede como todo.

A simulação do modelo utópico mostrou ainda, que com condições mais favoráveis de reservação, adução e topologia, o SAM Leste é um sistema otimizável, que atende com folga às demandas setoriais, sem que os reservatórios esvaziem ou extravasem. Quer dizer então, que operado de maneira otimizada, a rede pode ter melhor desempenho em condições reais de operação.

Foram encontradas dificuldades na utilização da toolkit com relação às funções prontas disponíveis. Algumas não apresentavam de forma clara, a sua tarefa ou que tipo de resultado forneceria se comparando com o software Epanet 2.0 (Rossman, 2000) propriamente dito, dificultando a automatização e a eficiência desta interface.

\section{Análise de sensibilidade e índices utilizados no modelo otimizador}

A análise de sensibilidade mostrou que os melhores resultados são fornecidos considerando a carga inicial igual a $90 \%$ da carga máxima dos reservatórios, sendo esta então a condição inicial de operação mais investigada. Foram definidos para efeito de análise de desempenho do otimizador os seguintes índices, dados em percentual (\%):

- O índice de potência total utilizada por todos os equipamentos segundo os AG's em relação ao praticado pelo CCO da Sabesp (INDICEPOT), em função do acionamento das bombas no período simulado de $24 \mathrm{~h}$, do melhor indivíduo;

-O índice de manobras (INDICEMANOBRA), definido como a razão entre a quantidade de manobras ou acionamento de todas as válvulas pelo praticado pelo Centro de 
Controle Operacional (CCO) da SABESP, do melhor indivíduo;

-O índice de oscilação de nível (ION) nos reservatórios, na razão da diferença entre o nível máximo e o nível mínimo observados na otimização, dividida pela diferença entre os limites máximo operacional (limite alto) e mínimo operacional (limite baixo), de cada reservatório da solução ótima e,

- O de amplitude entre as vazões aduzidas a cada reservatório, na razão da diferença entre as vazões máxima e mínima, dividida pela vazão média, da solução ótima.

Segundo Sabesp (1999), o diagnóstico da reservação do SAM foi elaborado em função da determinação dos valores de volume nominal, útil e necessário dos reservatórios, e da determinação do Rendimento da Reservação (RR) e da Ocupação do Reservatório (OR). Para melhor entendimento dos termos utilizados, são apresentadas a seguir algumas definições referentes aos reservatórios e condições de operação dos mesmos, de acordo com a Figura 2, conforme Sabesp (1999).

-Volume nominal (Vnom.): É o volume total do reservatório, compreendido entre a laje de fundo do reservatório e o limite de extravasamento.

-Volume útil (Vútil): É o volume compreendido entre o limite alto e o maior valor entre o limite baixo e o limite de falta d'água. Representa o volume efetivamente disponível para regularizar as demandas de consumo setoriais.

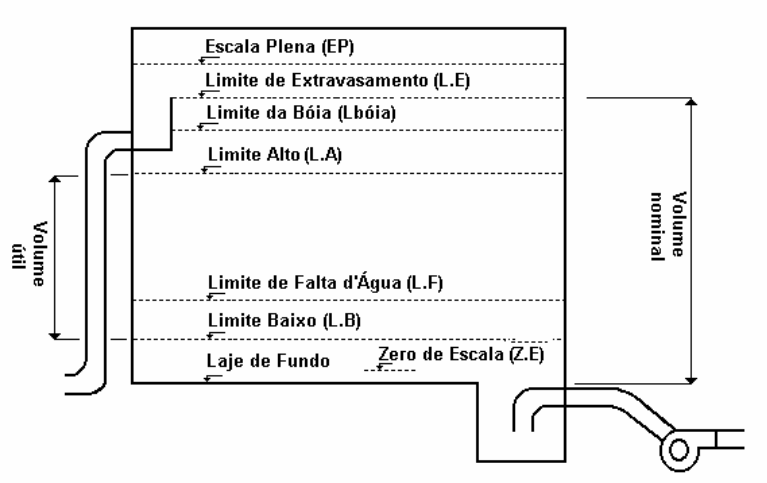

Figura 2- Níveis operacionais dos reservatórios setoriais

- Volume necessário (Vnec.): É o volume necessário para regularizar as demandas diárias de consumo, admitindo-se uma vazão de adução constante, igual ao consumo médio diário.

-Rendimento do Reservatório (RR): É a relação entre os volumes útil e nominal do reservatório, dada pela equação (13), abaixo:

$$
R R(\%)=\text { Vútil/Vnom }
$$

Esse parâmetro é um bom indicador da eficiência da utilização do reservatório.

-Ocupação do Reservatório (OR): É a relação entre os volumes necessário e útil do reservatório, dada pela equação (14):

$$
O R(\%)=\text { Vnec/Vútil }
$$

Segundo informações do referido relatório, para o índice de rendimento de reservação $(R R) \circ$ valor mínimo aceitável é $70 \%$. Assim, o Reservatório Itaquera possui rendimento de reservação aquém do limite mínimo aceitável.

No caso do índice de ocupação dos reservatórios $(\mathrm{OR})$, o máximo valor aceitável de ocupação é de $70 \%$. Analisando o índice OR da Tabela 2, os Reservatórios Itaquera, Ferraz de Vasconcelos, Poá e Itaim, operam com condições críticas de reservação indicando déficits de capacidade em 4 (quatro) de um total de 9 (nove) reservatórios do SAM Leste. Vale ressaltar que os volumes nominais dos Reservatórios Ferraz de Vasconcelos e Itaim utilizados no modelo de simulação e de otimização são diferentes aos utilizados no relatório Sabesp (1999) e por isso o volume útil, RR e OR foram recalculados, para se adequarem aos volumes nominais utilizados nesta tese.

Os comentários referentes ao índice OR valem para estes valores recalculados.

Tabela 2 - Características operacionais dos reservatórios utilizadas nos modelos

\begin{tabular}{|l|l|l|l|l|l|l|}
\hline Reservatórios & $\begin{array}{c}\text { Vol. } \\
\text { Nom. } \\
\text { Real } \\
\left(\mathrm{m}^{3}\right)\end{array}$ & $\begin{array}{l}\text { Vol. } \\
\text { Nom. } \\
\text { Ideal } \\
\left(\mathrm{m}^{3}\right)\end{array}$ & $\begin{array}{l}\text { Vol. } \\
\text { Útil } \\
\left(\mathrm{m}^{3}\right)\end{array}$ & $\begin{array}{l}\text { Vol. } \\
\text { Nec. } \\
\left(\mathrm{m}^{3}\right)\end{array}$ & $\begin{array}{l}\text { RR } \\
(\%)\end{array}$ & $\begin{array}{l}\text { OR } \\
(\%)\end{array}$ \\
\hline Guaianazes & 5.000 & 11.000 & 4.365 & 2.696 & 87.30 & 61.76 \\
\hline Brás Cubas & 20.000 & 10.000 & 15.062 & 5.770 & 75.31 & 38.31 \\
\hline Suzano & 10.000 & 11.000 & 7.833 & 3.079 & 78.33 & 39.31 \\
\hline Itaquera & 24.000 & 20.000 & 14.857 & 13.709 & 61.90 & 92.27 \\
\hline F.Vasconcelos & 2.000 & 5.000 & 1.531 & 4.506 & 76.55 & 294.33 \\
\hline Poá & 5.000 & 5.000 & 3.607 & 2.968 & 72.14 & 82.28 \\
\hline Itaim & 15.000 & 19.000 & 12.475 & 13.738 & 83.17 & 110.12 \\
\hline Itaquaquecetuba & 15.000 & 8.000 & 12.301 & 5.406 & 82.01 & 43.95 \\
\hline
\end{tabular}


Observa-se ainda, que a maioria dos reservatórios da área estudada possui volume nominal real aquém do ideal, isto é, menor ou igual a $1 / 5$ da demanda diária $\left(\mathrm{m}^{3}\right)$, de acordo com a Tabela 2.

Por esse motivo, grande é a dificuldade encontrada pelo algoritmo de operar esses reservatórios de maneira tal, que as vazões de adução sendo variáveis de decisão, se mantenham em patamares de variação razoáveis (20\%), e assim atender às restrições impostas na função de fitness.

Para melhor descrição do desempenho dos reservatórios do SAM Leste, conforme os níveis máximos e mínimos observados na operação otimizada, adotou-se neste estudo, o índice de oscilação de nível em relação ao índice OR. ION_OR é:

A formulação deste novo índice chamado

$$
I O N_{-} O R(\%)=I O N / O R
$$

Para uma melhor visualização do desempenho dos reservatórios quanto ao índice de oscilação de nível (ION), em relação ao índice ocupação dos reservatórios (ION_OR), criou-se uma escala em percentual, que qualifica $\mathrm{O}$ desempenho do reservatório em ruim, razoável, satisfatório e bom, ilustrada na Figura 3:

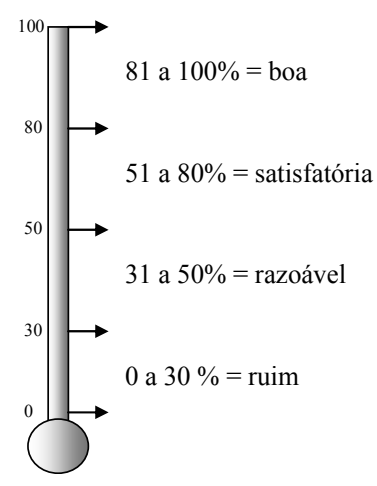

Figura 3 - Escala de desempenho dos reservatórios

A combinação de pesos aplicada à função de fitness e a nomenclatura utilizada foi a seguinte, de acordo com a Tabela 3:
Tabela 3 - Combinação de pesos aplicados à função de fitness

\begin{tabular}{|c|c|c|c|c|c|}
\hline Nome & $\begin{array}{c}\text { Custo } \\
\text { EE }\end{array}$ & $\begin{array}{c}\text { PenaNiv } \\
\text { Min }\end{array}$ & $\begin{array}{c}\text { PenaNiv } \\
\text { Max }\end{array}$ & $\begin{array}{c}\text { Pena } \\
\text { Man }\end{array}$ & $\begin{array}{c}\text { Pena } \\
\text { NivIF }\end{array}$ \\
\hline Não & - & - & - & - & - \\
\hline Tipo 1 & 0.10 & 0.10 & 0.10 & 0.10 & 0.60 \\
\hline Tipo 2 & 0.40 & 0.30 & 0.10 & 0.10 & 0.10 \\
\hline Tipo 3 & 0.60 & 0.20 & 0.05 & 0.10 & 0.05 \\
\hline
\end{tabular}

\section{Resultados do modelo de otimização}

Foram otimizados 33 cenários com diversas variações entre os níveis iniciais de operação, combinações de pesos, parâmetros de AG's de população, número de gerações, probabilidades de cruzamento e de mutação e que resultaram em diferentes custos de energia elétrica, de potência consumida ( $\mathrm{kW}$.dia) na regra dos AG's em relação à do CCO (INDICEPOT), quantidade de manobras totais variadas propostas pelos AG's em relação ao CCO e oscilação de nível dos reservatórios em relação ao seu rendimento e ocupação.

Os cenários $03,07,11,18,28$ e 30, foram escolhidos para serem comentados com mais detalhes, por serem mais representativos da sensibilidade dos AG's aos diversos parâmetros escolhidos para cada cenário otimizado, dentre todos simulados. Assim estes cenários foram resumidos na Tabela 4 .

Tabela 4 - Resumo final da otimização via AG's do SAM Leste

\begin{tabular}{|c|c|c|c|c|c|c|c|c|c|c|c|}
\hline \multicolumn{12}{|c|}{ CENÁRIOS OTIMIZADOS DA OPERAÇÃO DO SAM LESTE VIA AG'S } \\
\hline cenário & PESO & \begin{tabular}{|c} 
Nivel \\
inicial de \\
operaço \\
\%\%)
\end{tabular} & $\begin{array}{c}P C R U Z \\
(\%)\end{array}$ & $\begin{array}{l}\text { PMUT } \\
(\%)\end{array}$ & PopSize & Iger & $\begin{array}{c}\begin{array}{c}\text { CustoEE } \\
\text { (adim.) }\end{array} \\
\text { (adim. }\end{array}$ & $\begin{array}{l}\text { IndicePot } \\
\text { AG/CCO } \\
\text { (\%) }\end{array}$ & $\begin{array}{l}\begin{array}{l}\text { Indice de } \\
\text { Amplitude } \\
\text { de vazo } \\
\text { (\%) }\end{array} \\
\text { (\%) }\end{array}$ & \begin{tabular}{|c|} 
Indice \\
Manabobra \\
Aalcho \\
$(\%)$
\end{tabular} & $\begin{array}{c}\text { I.O.N_OR } \\
\text { MEDDO } \\
(\%)\end{array}$ \\
\hline 3 & TIPO 2 & 90 & 30 & 0,2 & 10 & 20 & 0,17 & 83 & 54 & 195 & 102 \\
\hline 7 & TIPO 3 & 90 & 30 & 10 & 10 & 400 & 0,24 & 79 & 63 & 202 & 88 \\
\hline 11 & TIPO 3 & 90 & 30 & 0,5 & 200 & 40 & 0,21 & 71 & 41 & 59 & 89 \\
\hline 18 & TIPO 1 & 90 & 50 & 10 & 10 & 20 & 0,047 & 90 & 57 & 172 & 103 \\
\hline 28 & $\mathrm{TIPO}_{2}$ & 70 & 80 & 1 & 200 & 40 & 0,14 & 72 & 45 & 65 & 100 \\
\hline 30 & NÃO & 100 & 80 & 0,2 & 200 & 400 & 0,35 & 71 & 41 & 61 & 89 \\
\hline \multicolumn{7}{|c|}{ MÉDIA } & 0,19 & 78 & 50 & 126 & 95 \\
\hline
\end{tabular}

Na Tabela 5 , são apresentados os valores médios dos custos adimensionais, índices ION_OR, INDICEPOT, INDICEMANOBRA e amplitude máxima de vazões, considerando os seis cenários analisados neste item. O CustoEE, custo adimensional de energia elétrica é de $0.20 \mathrm{em}$ média, significando que a operação proposta pelos AG's para o SAM Leste está em um patamar próximo da realidade operacional da área de estudo, pela quantidade de bombas acionadas na 
estratégia dos AG's em relação ao praticado pelo CCO. Quanto mais bombas acionadas, o custo real é mais próximo do custo máximo, obtendo-se então da equação (5), valores mais próximos de zero (1 menos este percentual) e quanto menos acionamentos, menor o custo real. Assim, o CustoEE distancia-se de zero mostrando que, se o modelo fornecesse uma operação de maior custo, este valor estaria próximo de zero, mas como está em 0.20 , a otimização proposta pelos AG's contempla uma operação otimizada e viável, para o SAM Leste. O consumo de energia em termos de potência é em média, de $78 \%$ daquela consumida na operação feita pelo $\mathrm{CCO}$, indicando que as estratégias operacionais praticadas pelo CCO devem ser revistas, de forma a melhorar o desempenho do SAM Leste, em termos de economia de energia elétrica consumida pelos boosters e estações elevatórias.

As estratégias propostas nos seis cenários levaram a um índice de manobra médio de $126 \%$, isto é $26 \%$ a mais em média, em relação às regras de manobras praticadas pelo $\mathrm{CCO}$. Isto ocorreu pelo fato de que nos cenários com PMUT de $10 \%$, ocorreram muitos acionamentos das válvulas, decorrentes da variabilidade das vazões de entrada dos reservatórios. Ë uma desvantagem das altas probabilidades de mutação, que introduz muita perturbação aleatória nas soluções, levando o AG a ter maior dificuldade de buscar por boas soluções. As vazões de entrada nos reservatórios, fornecidas pelos AG's como variáveis de decisão real, têm seu índice médio de amplitude da ordem de $50 \%$. Este valor é considerado aceitável, visto toda a dinâmica envolvida na operação dos reservatórios e os efeitos que, obviamente, a decisão do modelo acerca destas variáveis impacta, na sustentabilidade da rede no atendimento às suas demandas.

De todo SAM Leste, observa-se que, na média, os reservatórios oscilam seus níveis com ION_OR de 95\%, valor este considerado bom, já que é um valor médio entre nove reservatórios, das mais diversas características e limitações, físicas e operacionais, que não violam seus limites operacionais e atendem às suas demandas setoriais.

Dentre os cenários analisados, o modelo otimizador propõe o cenário 11 , como o de melhor cenário de otimização pelos ag's, dentre os cenários analisados. Os parâmetros de ag's de $30 \%$ de pcruz, $0.5 \%$ de pmut, $90 \%$ de nível inicial de operação e utilização de pesos tipo 3 , em uma população de 200 indivíduos para 40 gerações, corroboraram para seu desempenho. A figura 4 mostra a evolução de fitness para os vários cenários da tabela 5 .

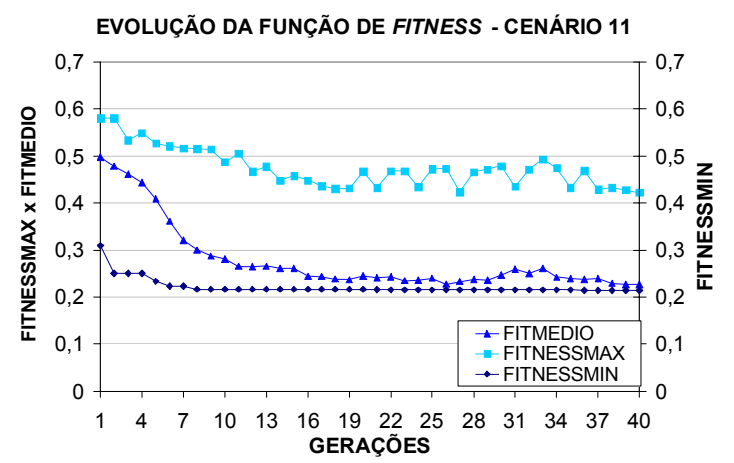

Figura 4 - Evolução de FitnessMax, Fitmedio e FitnessMin do cenário 11

No cenário 11, observa-se então uma evolução estável da função de FitnessMax, FitMedio (fitness médio da população) e FitnessMin. Mesmo que com pouca evolução genética em 40 gerações, os valores de FitnessMin e FitMedio apresentam tendência de aproximação, mostrando que na média, os indivíduos da população estão melhores por se aproximar dos melhores valores de fitness. Em termos de evolução de fitness em relação ao custo do consumo de energia elétrica, das estratégias ótimas propostas (CustoEE), os diferentes comportamentos estão apresentados na Figura 5.

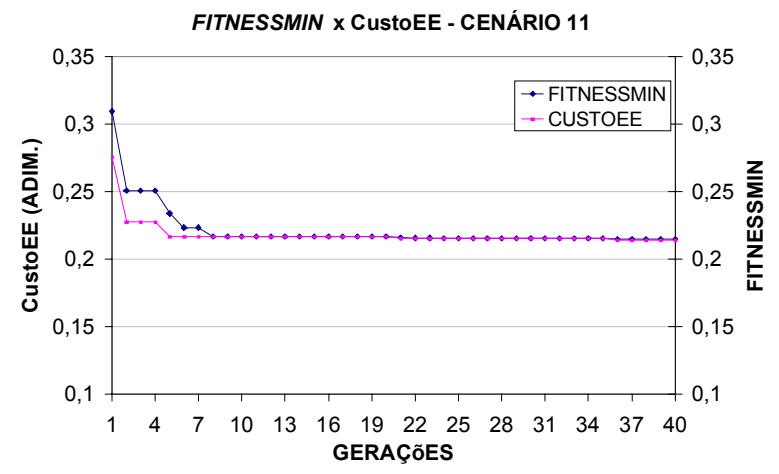

Figura 5 - Evolução da função de FitnessMin versus CustoEE

Observa-se que o comportamento das curvas de CustoEE e FitnessMin, são semelhantes a menos da escala, onde se nota a coincidência das duas curvas na maior parte das gerações. Com relação aos valores de custos de energia e potência utilizada, observa-se que neste cenário, onde a dimensão da população oferece 
diversidade para busca ótima com menos mutações, tem-se os menores valores de INDICEPOT, ou seja, menos bombas acionadas (Tabela 5).

Os custos adimensionais (CustoEE), são influenciados pela combinação de pesos aplicados (tipo). Nos cenários que fazem uso de pesos, seus custos adimensionais são maiores se a quantidade de bombas acionadas (mais potência consumida) é menor. Explicando melhor. Pela equação (5), o CustoEE seria igual à unidade se o custo máximo (todas as bombas operando $24 \mathrm{~h}$ ) fosse igual ao custo real (proposto pelo AG), ou seja, a operação máxima e a mais indesejada. Quando o custo real é menor que o custo máximo como se deseja, esta relação é um percentual do custo máximo. Quanto mais bombas acionadas, o custo real é mais próximo do custo máximo, obtém-se então da equação (5), valores mais próximos de zero (1 menos este percentual) e quanto menos acionamentos menor o custo real, o CustoEE distancia-se de zero.

Os valores apresentados na Tabela 5 ilustram bem essa variabilidade com e sem pesos.

A análise do comportamento das penalidades de violação do nível mínimo (PenaNivMin), de violação do nível máximo (PenaNivMax) e de nível inicial de operação maior que o nível final (PenaNiviF), é apresentada no gráfico da Figura 6:

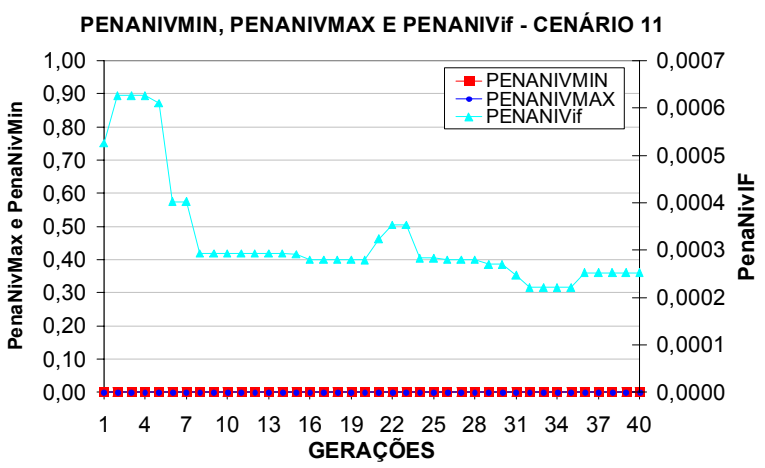

Figura 6 - Comportamento das penalidades PenaNivMax, PenaNivMin e PenaNiviF

Observa-se na Figura 6 que as penalidades de nível mínimo e máximo, não foram violadas na solução proposta. A penalidade de nível inicial maior que o final tem grande influência das características e limitações da rede em termos de topologia e da operação. O cenário $11 \mathrm{com}$ peso aplicado de 0.05 , minimiza suas violações, mas mostra certa dificuldade do AG, em encontrar soluções com boa finalização na operação dos reservatórios.

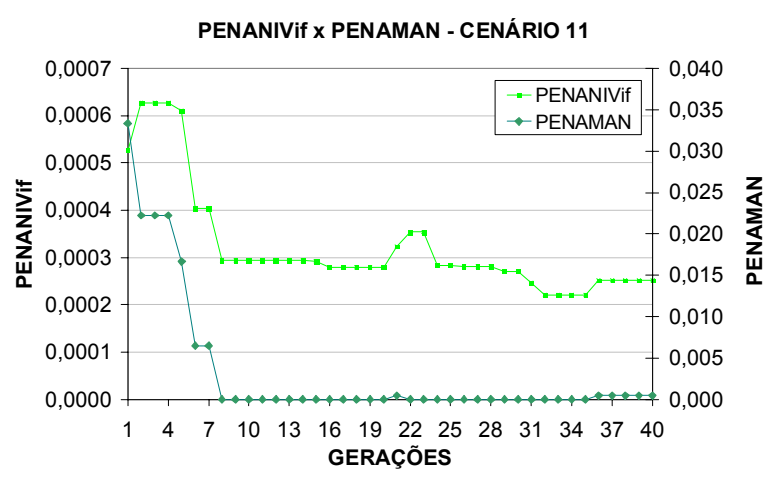

Figura 7 - Comportamento das penalidades PenaMan e PenaNivIF

No gráfico da Figura 7, nota-se que a quantidade de manobras nas válvulas influencia na maneira como os reservatórios finalizam sua operação. Observa-se que, quando o número de manobras é reduzido ou tende a redução, os reservatórios tendem a operar de forma mais acertada, e os níveis finais de operação tendem a voltar para o nível inicial de operação ou estar próximo dele, violando menos a penalidade PenaNiviF. O cenário 11 , é o que têm menor INDICEMANOBRA (59\%) e também melhor evolução das curvas de PenaMan, pois nas soluções ótimas da última geração, a quantidade de manobras de todas as 9 válvulas, ficou abaixo valor desejável estipulado de 27 (3 manobras/dia), no cenário 11. Com relação às soluções ótimas de operação dos reservatórios propostas pelos AG's, a Figura 8 ilustra graficamente, as estratégias operacionais aqui representadas pelo 0 Reservatório Itaim.

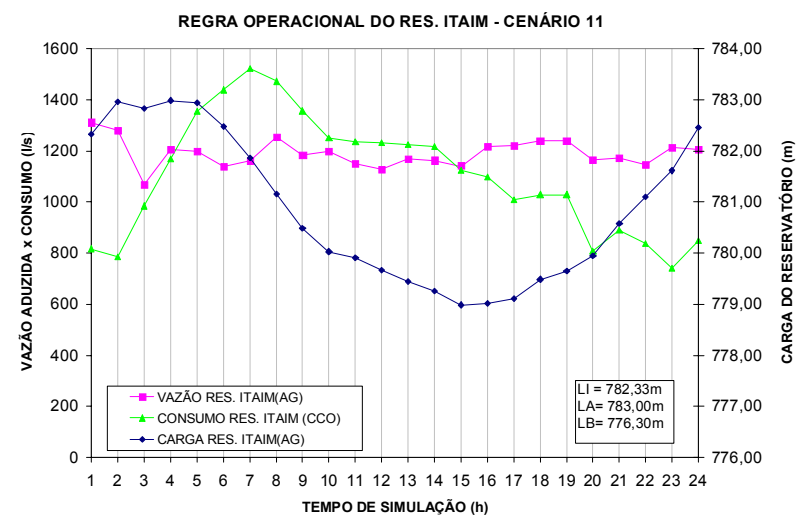

Figura 8 - Operação otimizada do Reservatório Itaim 
A Figura 8 mostra que o modelo de otimização propôs boa regra operacional para Reservatório Itaim. A oscilação de nível representada pelo índice ION foi de $60 \%$, para o cenário 11.

De acordo com a escala de desempenho, o Reservatório Itaim tem desempenho satisfatório sendo o de menor oscilação, o cenário 11 . O índice ION_OR obtido foi de $54 \%$. Isto é, o Reservatório Itaim deveria oscilar consideravelmente, dentro de seus limites alto e baixo de operação, utilizando em média $54 \%$ do volume útil para regularizar as demandas do seu setor da rede.

O cenário 11 não viola a penalidade PenaNivIF por finalizarem a operação com nível final acima do nível inicial.

As estratégias de vazão de entrada propostas para o cenário, fornecem índice de amplitude de vazões de $20 \%$, sendo o melhor valor, que alcança a amplitude de manobras máxima definida como de $20 \%$.

Com base na operação apresentada para o SAM Leste no cenário analisado, a estratégia de pesos aplicada influencia o $A G$ de forma mais secundária na escolha da regra ótima de operação, sendo que os parâmetros de população e probabilidade de mutação, são as condições mais impactantes e decisivas no processo de otimização dos AG's.

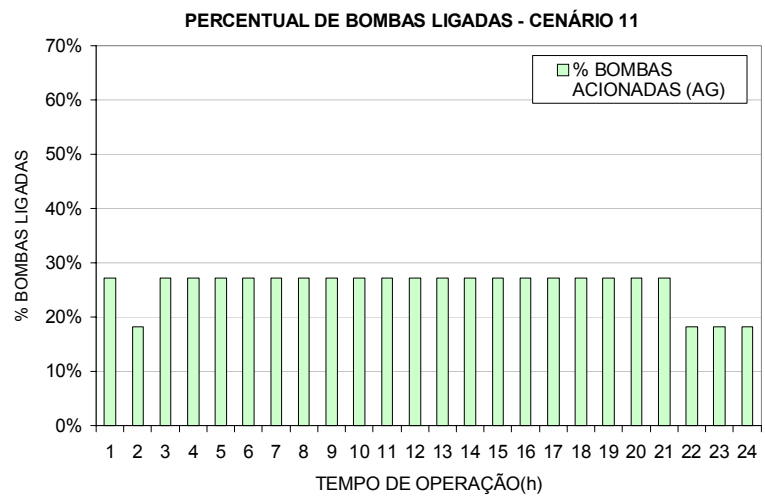

Figura 9 - Percentual de operação dos boosters e estações elevatórias dos cenários otimizados

A Figura 9 mostra o percentual de grupos moto-bombas em operação no período simulado, considerando o total de 11 equipamentos do SAM Leste, para o cenário de otimização 11 , sendo este percentual de $56 \%$ e o de menor quantidade de equipamentos acionados.
O cenário 11 mantém um padrão estável de operação, tanto no horário de ponta, com $7 \%$ de equipamentos em operação e $49 \%$ no horário fora de ponta, totalizando $56 \%$.

Isso implica em $2.430 \mathrm{~kW}(13 \%)$ de potência consumida no horário de ponta (maior consumo e tarifa mais cara) e $16.126 \mathrm{~kW}(88 \%)$ no horário de fora ponta, num total diário de $18.556 \mathrm{~kW}$ (18.6MW).

A potência consumida no horário de ponta é da proporção de 1:6 em relação ao horário fora de ponta. Os consumos de energia elétrica nos horários de ponta (3h de operação) e fora de ponta (20h de operação em média), neste cenário, foram de 810kW.h e 806kW.h, respectivamente. Proporcionalmente o consumo no horário de fora de ponta em relação ao consumo no horário de ponta é aproximadamente 1:1.

Comparando a regra do $\mathrm{CCO}$, com a operação de maior potência consumida proposta pelos AG's, que é de $23.6 \mathrm{MW}$ do cenário 18 , obtém-se uma redução de $10 \%$ na potência consumida, sendo a regra dos AG's uma proporção de 1:1.1 da regra do CCO. Em valores monetários são $R \$ 20.531,00 /$ dia.

Comparando o consumo de energia elétrica da regra dos AG's com a do CCO, a redução é de $24 \%$ (1.119kW.h dos AG's versus $1.473 \mathrm{~kW} . \mathrm{h}$ do $\mathrm{CCO}$ ) no horário de ponta, que é o de tarifa mais elevada, resultando em $\mathrm{R} \$ 209,23 /$ dia.

Em termos de consumos de energia elétrica nos horários de ponta e fora de ponta, os cenários 11 e 30 apresentam redução de $45 \%$ $(R \$ 151,00 /$ dia $) \quad$ e $\quad 35 \% \quad(R \$ 72,57 /$ dia $)$, respectivamente, em relação à regra do $\mathrm{CCO}$. A proporção fica em torno de 1: 1.6 da regra dos AG's em relação à do $\mathrm{CCO}$.

O valor da potência consumida é reduzido mais ainda no cenário 11 (18.6MW), para $29 \%$, em relação aos $26.216 \mathrm{~kW}$ consumidos na operação do CCO.

Em termos de consumos de energia elétrica nos horários de ponta e fora de ponta, o cenário 11 apresenta redução de $45 \%$ e $35 \%$, respectivamente, em relação à regra do $\mathrm{CCO}$. A proporção fica em torno de 1: 1.6 da regra dos AG's em relação à do CCO.

Já comparando-se o cenário 11 com o cenário 18 que o de maior consumo de energia elétrica proposto pelos AG's, essa redução nos horários de ponta e fora de ponta são de $28 \%$ e $60 \%$, respectivamente. 
STA. ETELVINA - CENÁRIO 11

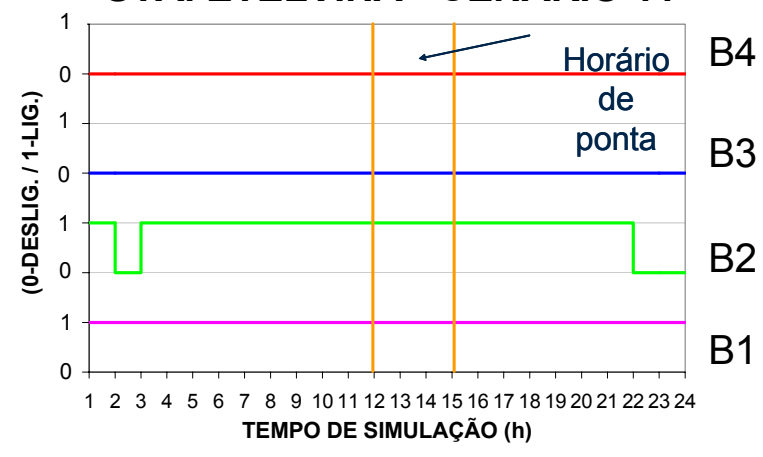

Figura 10 - Esquema de operação da Estação Elevatória Santa Etelvina no cenário 11

Observa-se na Figura 10, que na operação da Estação Elevatória Santa Etelvina no cenário em análise, a bomba B1 está ligada nas 24h. A bomba B2 tem operação com mais acionamentos (20) contra 15 do CCO. A bomba B3 e B4 permanecem fora de operação.

O consumo de energia da Estação Elevatória Santa Etelvina representa em termos de percentual, um valor de $52 \%$ do total de consumo para os cenários de menor custo, que são o 11 e o 30 , e $45 \%$ para o cenário 18 , o de maior custo.

Foi utilizado, nas simulações, um computador pessoal com microprocessador tipo Pentium 4 com $2.2 \mathrm{GHz}$ de velocidade. Para a otimização do cenário 11, com 200 indivíduos e 40 gerações, o tempo médio é de 3 horas e 20 minutos de otimização completa (simulador + otimizador).

O Epanet 2.0 (Rossman, 2000) gasta deste total, cerca de 2 horas e o tempo restante de 1 hora e 20 minutos é gasto pelo AG. De todas estas as configurações de processamento, tanto a interface do simulador hidráulico quanto a interface com o banco de dados e os arquivos de resultados não dura mais que décimos de segundos cada, e por isso sua medida não é de comentário significativo.

Para uma otimização com pouco tempo disponível para simulações, o cenário 11 é uma boa alternativa para o dia-dia e em tempo real. Observa-se que, para uma otimização com maior disponibilidade de tempo para simulação, a configuração do cenário 30 é uma boa opção.

\section{CONCLUSÕES}

Com base nos resultados das simulações apresentados, pode-se concluir o seguinte:

Nos seis cenários escolhidos, o cenário 11 foi o que teve melhor desempenho em termos de qualidade dos resultados obtidos, e o pior foi 0 cenário 07. As diferenças entre eles foram o tamanho da população, PMUT e o número de gerações, pois a probabilidade de cruzamento de $30 \%$, a combinação de pesos tipo 3 e o nível inicial de operação em $90 \%$ foram iguais para os dois cenários.

Em termos de potência utilizada pelas bombas dos boosters e estações elevatórias, o (INDICEPOT), significa uma redução de $22 \%$ de potência $(\mathrm{kW})$ consumida pelas bombas no período simulado da Sabesp. Em valores monetários a redução diária média é de $\mathrm{R} \$ 25.750,00$.

A escolha dos dados e a sua qualidade deve ser rigorosa, fornecendo subsídios para atender aos objetivos do trabalho e contribuir no êxito dos resultados.

O modelo Epanet 2.0 (ROSSMAN, 2000), utilizado na simulação hidráulica e a toolkit utilizada na interface com o otimizador são bons e as maiores dificuldades encontradas foram quanto ao entendimento do que efetivamente o modelo fazia, os procedimentos e a formatação da toolkit na interface.

Verificou-se que níveis iniciais de operação têm forte impacto no desempenho do modelo de otimização quanto à geração soluções viáveis, e os melhores resultados foram obtidos com $90 \%$ de carga inicial de operação.

Verificou-se que além de influenciar na velocidade de processamento dos AG's, o tamanho mais adequado deve ser aquele que dê aos AG's diversidade de opções na busca qualitativa por boas soluções, mas também velocidade para evitar perda de tempo na obtenção da solução ótima.

Recomenda-se avaliar cuidadosamente o problema a ser investigado e os objetivos a serem alcançados. O tamanho ideal depende da dimensão do problema, da quantidade de variáveis de decisão, complexidade da rede e do tempo disponível para se obter a solução ótima.

Observou-se que, neste problema, probabilidades baixas de cruzamento (30\%) obtiveram melhores resultados na otimização da operação que as probabilidades mais altas (80\%). Observou-se que probabilidades de mutação muito baixas $(0.2 \%)$ não dão chance ao $A G$ de pesquisar outros pontos do espaço de soluções. Em compensação, probabilidades mais altas (10\%) acabam por perturbar a busca e ser danosa a 
soluções que poderiam ter melhor desempenho a menos da mutação de um gene.

As simulações mostraram que o AG é mais sensível ao tamanho da população e aos operadores genéticos de cruzamento e mutação, do que aos pesos.

Neste trabalho, observou-se que muitas gerações desenvolvidas, sem uma boa estratégia de otimização não ajudam muito. Em várias situações, observou-se convergência prematura tanto em poucas gerações, quanto em 2.000 gerações, produzindo soluções viáveis, mas nem sempre retratando boa opção operacional.

O índice médio de amplitude de vazões entre os seis cenários é de $50 \%$, também considerado bom se observadas as particularidades e a dinâmica de operação de cada setor do SAM Leste.

O modelo de otimização mostra melhora em seu desempenho, se forem mantidas mais soluções fora do processo de cruzamento com probabilidade de cruzamento de $30 \%$, isto é, boas soluções permanecerem intocadas na população, contribuindo no processo evolutivo ao longo das gerações.

Os AG's são lentos em seu processo de escolha da solução ótima, assim se combinados com heurísticas de busca local serão mais eficientes que o AG puro aqui aplicado, sendo mais eficiente, portanto, na aplicação em tempo real.

A verificação de políticas de penalização com pesos deve ser verificada a aplicada conforme as características de cada problema.

Não se pretendeu aqui, solucionar todos os problemas inerentes à operação dos sistemas adutores e de distribuição de água, mas sim fornecer uma ferramenta, que associada a um sistema de monitoramento SCADA e a simuladores hidráulicos, otimizasse com os Algoritmos Genéticos a operação de um sistema real, grande, complexo e limitado, auxiliando os operadores e gestores na tomada de decisão, face aos cenários de operação diários e aos problemas que se apresentam diante do corpo técnico, desta área da Engenharia Hidráulica.

\section{Agradecimentos}

Os autores agradecem à Universidade de

São Paulo (USP), à Coordenação de Aperfeiçoamento de Pessoal de Nível Superior (CAPES), pelo fornecimento da bolsa de estudos pelo suporte financeiro oferecido para $\mathrm{O}$ desenvolvimento deste trabalho.

\section{REFERÊNCIAS BIBLIOGRÁFICAS}

AHMED, J.A. e SARMA, A.K. (2004). "Genetic algorithms for optimal operating policy of a multipurpose reservoir." Water Resources Management, p. 1-17. 2004.

BARR et al. (1995). "Design and reporting on computational experiments with heuristic methods." Postscript, Dallas, TX, June. 1995.

BORGES, V. M. (2003). "Acoplamento de um modelo de previsão de demanda de água a um modelo simulador em tempo real, um estudo de caso: sistema adutor metropolitano de São Paulo". Dissertação (Mestrado), Univ. São Paulo, São Paulo.

BRION, L.M. e MAYS, L.W. (1991). "Methodology for optimal operation of pumping stations in water distribution systems." Journal of Hidraulic Engineering. 117(11), 1551 - 1569, 1991.

CHANG, N-B. e WEI, Y.L. (2000). "Siting recycling drop-off stations in urban area by genetic algorithm-based fuzzy multiobjective nonlinear integer programming modeling." Fuzzy Sets and Systems. 114, 133-149, 2000.

CIPPARRONE, F.A.M.(1995). "Otimização do controle operacional de sistemas hidráulicos complexos." Tese (Doutorado). Univ. São Paulo, São Paulo, 1995.

Companhia de Saneamento Básico do Estado de São Paulo (SABESP). Departamento de Desenvolvimento Operacional da Produção. Divisão de Processos de Água. "Estudo de Otimização da Reservação do SAM." Revisão 1. São Paulo. 1999.

CUI, L-J. e KUCZERA, G. (2003). "Optimizing urban water supply headworks using probabilistic search methods." Journal of Water Resources Planning and Management. 129(5), 380-387, september, 2003.

DEB, K. (2000). "An efficient constraint handling method for genetic algorithms." Computer Methods in Applied Mechanics and Engineering. 186, 311-338, 2000.

DIBA, A. et al. (1995). "Planned operation of largescale water distribution system." Journal of Water Resources Planning and Management. 121(3), 260-269, may-june, 1995.

DRAPER, A. J. et al. (2003) "Economic-engineering optimization for California water management." Journal of Water Resources Planning and Management. 129(3), 155-164, may, 2003.

FRANCATO, A. L. (2002). "Operação multiobjetivo de sistemas urbanos de abastecimento de água." Tese (Doutorado), Univ. Campinas. Campinas, 2002. 
FUJIWARA, O. e TUNG, H.D. (1991). "Reliability improvement for water distribution networks through increasing pipe size." Water Resources Research. 27(7),1395-1402, july, 1991.

GAMBALE, S.R. (2000). "Aplicação de algoritmo genético na calibração de redes de água." Dissertação (mestrado), Univ. São Paulo. São Paulo, 2000.

GEN, M. e CHENG, R. (1997). Genetic Algorithms and Engineering Design. Canada, John Wiley e Son.

GOLDBERG, D.E. (1987). Genetic Algorithm in search, optimisation and machine learning, Addison-Wesley, Reading, Mass.

GOULTER, I.C.e COALS, A. V. (1986). "Quantitative approaches to reliability assessment in pipe networks." Journal of Transportation Engineering. 112(3), 287-301, may, 1986.

GOULTER, I.C.; BOUCHART, F. (1990). "Reliability-constrained pipe network model." Journal of Hidraulic Engineering. 116(2), 211229, february, 1990.

HOLLAND, J. H. (1975). 'Adaptation in natural and artificial systems." MIT Press. Cambridge, Massachussets, 1975.

LABADIE, J. W. (2004). "Optimal operation of multi-reservoir systems: state-of-art review." Journal of Water Resources Planning and Management. 130(2), 93-111, march-april, 2004.

LEÓN, C. et. Al. "EXPLORE - Hybrid expert system for water networks management." Journal of Water Resources Planning and Management. 126(2), 65-74, march-april, 2000.

LI, F. e AGGARWAL, R.K. (2000). "Fast and accurate power dispatch using a relaxed genetic algorithm and a local gradient technique." Expert Systems with Applications. 19, 159-165, 2000.

LUVIZZOTO JÚNIOR, E. (1995). "Controle operacional de redes de abastecimento de água auxiliado por computador." 1995. Tese (Doutorado), Univ. São Paulo. São Paulo, 1995.

MEIER, R.W. e BARKDOLL, B.D. (2000). "Sampling design for network model calibrating using genetic algorithm." Journal of Water Resources Planning and Management. 126(4), 245-250, july-august, 2000.

MICHALEWICS, Z. (1994). "Genetic Algorithm + data structures $=$ evolution programs." $2^{\text {a }}$.ed., Springer-Verlag, New York.

MIRANDA, V., SRINIVASAN, D. e PROENÇA, L.M. (1998). "Evolutionary computation in power systems." Eletrical Power \& Energy Systems. 20(2), 89-98, 1998.

MURTAGH, B.A. e SAUNDERS, M.A. (1987). Minos 5.1 User's Guide. Technical Report. 1987.

OLIVEIRA, R. e LOUCKS, D.P. (1997). "Operating rules for multireservoir systems." Water Resources Research, 33(4), 839-852. april, 1997.

ORMSBEE, L.E. e LANSEY, K.E. (1994). "Optimal control of water supply pumping systems." Journal of Water Resources Planning and Management. 120(2), 237-252, marchapril,1994.

PEZESHK, S.; HELWEG, O.J.; OLIVER, K.E. (1994). "Optimal operation of groundwater supply distribution systems." Journal of Water Resources Planning and Management. 120(5), 573-585, september-october, 1994.

REIS, L.F.R.; PORTO, R. M. \& CHAUDHRY, F.H. (1997). "Optimal location of control valves in pipe networks by genetic algorithms." Journal of Water Resources Planning and Management. 123(6), 317-326, novemberdecember, 1997

REIS, L.F.R; AKUTSU, J. (2002). "Estratégias operacionais para sistemas de reservatórios via algoritmos genéticos (AGs)." Revista Brasileira de Recursos Hídricos. 7(3), JulhoSetembro, 5-17, 2002.

RIBEIRO, G.P. (2000). "Custos de produção de águas subterrâneas com operação otimizada via algoritmos genéticos para o abastecimento urbano de araraquara/SP." 2000. Dissertação (Mestrado), Univ. São Paulo. São Carlos, 2000.

ROSSMAN, L.A. (2000). Epanet 2.0 Users Manual. U.S. Environmental Protection Agency. Cincinnati, Ohio. 2000.

SAKARYA, B.A. e MAYS, L.W. (1998). "Optimal operation of water distribution pumps considering water quality." Journal of Water Resources Planning and Management. 126(4), 210-220, july-august, 1998.

SAVIC, D. A.; WALTERS, G. A. e SCHWAB, M. Multiobjective genetic algorithm for pumping scheduling in water supply. In: AISB'97, Manchester, 1997. Evolutionary Computing workshop, Manchester, 1997. p.59.

VAN ZYL, J. E., SAVIC, D. A. e WALTERS, G. A. (2004). "Operation optimization of water distribution systems using a hybrid genetic algorithm." Journal of Water Resources Planning and Management. 130(2), 160-170, march, 2004. 
WAGNER, J.M., SHAMIR, U. e MARKS, D.H. (1998). "Water distribution reliability: simulation methods." Journal of Water Resources Planning and Management. 114(3), 276-294, may, 1988.

WARDLAW, R. e SHARIF, M. (1999). Evaluation of Genetic Algorithms for Optimal Reservoir System Operation, Journal of Water Resouces Planning and Management, ASCE, 125(1), 2533. 1999.

WATKINS, D.W.; MAcKINNEY, D.C. (1998). "Decomposition methods for water resources optimization models with fixed costs." Advances in Water Resources. 21, 283-295, 1998.

WOOD, D.J. (1981). KYPIPE. User's manual computer analysis of flow in pipe networks including extended period simulations. Univ. Kentucky, Lexington. 1981.

WURBS, R.A. (1993). "Reservoir-system simulation and optimization models." Journal of Water Resources Planning and Management, ASCE, 119(4),455-472.

YEH, W.W.-G. (1985). "Reservoir management and operation models: A state-of-the-art review." Water Resources Research, 21(12), 17971818, 1985

ZAHED, FILHO. K. (1990). "Previsão de demanda de consumo em tempo real no desenvolvimento operacional de sistemas de distribuição de água." Tese (Doutorado) Univ. São Paulo. São Paulo, 1990.

Optimized operation of metropolitan mains system using genetic algorithms. Case study: East metropolitan mains system of metropolitan region of São Paulo (M.R.S.P.).

\section{ABSTRACT}

This work proposes an optimization algorithm, using the Genetic Algorithms (GA's) method, associated at SCOA, the Sabesp's monitoring system, hydraulics simulator Epanet 2.0 (Rossman, 2000) and a water demands records, considered as forecasting perfect, verified the $G A$ 's application to optimize in real-time, the reservoirs operation and to minimize electrical energy consumption costs by East Metropolitan Mains System of Metropolitan Region of São Paulo (M.R.S.P.) boosters. Were examined six optimized representatives options of several weights combinations apllied to fitness function, population sizes, generations number, crossover and mutation probabilities investigated, proposing pump schedules and reservoirs operations strategies efficient scenery's, by optimization model. To be used in real- time, the GA's parameters must be carefully defined, to let be more effective and fast to obtain optimal solutions. The GA's presented good performance about operational solutions quality proposed, considering the large size, complexity and operational limitation of East Metropolitan Mains System.

Key words: optimization. water networks. genetic algorithms. 


\section{APRESENTAÇÃO}

A presente doutoranda sempre possuiu uma ligação muito forte com os recursos naturais, visto que é amazonense e de descendência indígena. Na graduação em Engenharia Civil no Instituto de Tecnologia da Amazônia, a satisfação maior era das aulas de disciplinas ligadas aos recursos hídricos.

Houve o momento de duas conclusões: primeira, o anseio de saber com mais profundidade sobre a utilização destes recursos pela engenharia e segunda, a água é o recurso natural do futuro e que deve ser preservado e bem utilizado para que as futuras gerações possam gozá-lo.

A primeira etapa seria o mestrado na Escola de Engenharia de São Carlos da Universidade de São Paulo, onde a área de otimização do custo da operação de sistema de abastecimento, cuja fonte eram os aqüíferos subterrâneos, utilizando a inteligência artificial dos Algoritmos Genéticos (AG’s), incutiria maior curiosidade nesta área tão fundamental da Engenharia Hidráulica, que é o abastecimento urbano de água.

Vislumbrou-se ainda pela literatura pesquisada, que poucos trabalhos eram desenvolvidos na área utilizando os AG's, na otimização de sistemas de grande porte, com interfaces a simuladores hidráulicos, de forma a produzir cenários de regras operacionais otimizadas e a viabilidade de se produzir estas regras, mais ambiciosamente, em tempo real.

$\mathrm{Na}$ busca de aperfeiçoar seus conhecimentos, esta doutoranda se deparou com a oportunidade de desenvolver uma tese de doutorado desta monta com o Prof. ${ }^{\circ}$ Dr. Kamel Zahed Filho, que já havia orientado uma dissertação de mestrado usando os AG's, para 
continuar o trabalho que ficara como recomendação futura de pesquisa na dissertação da autora em questão.

O orientador em questão, pelo seu trabalho na Companhia de Saneamento Básico do Estado de São Paulo (SABESP), localizou e sugeriu o SAM Leste como uma área a ser estudada por sua operação complicada e com boas possibilidades de promover bons resultados em nível de uma tese de doutorado.

Assim faz-se a necessidade deste trabalho de pesquisa de verificar, pela criação de um modelo de otimização, a aplicabilidade dos AG's na otimização dos custos de energia do SAM Leste e que esse modelo fornecesse ferramentas em termos de regras operacionais ótimas, contribuindo na assessoria aos operadores à tomada de decisão do dia-a-dia, se possível em tempo real, conforme constatado na tese a seguir. 


\section{OBJETIVOS}

O objetivo da tese é avaliar se os AG's permitem obter uma maximização da eficiência energética em um sistema de adução complexo e verificar se a velocidade de obtenção da solução ótima é compatível com uma operação em tempo real. 


\section{INTRODUÇÃO}

Atualmente, os sistemas de adução de água das grandes metrópoles, são progressivamente ampliados e submetidos a aumentos de demandas, e vêm desta forma, se constituindo em um problema cada vez mais crítico para os gerenciadores que operam esses sistemas.

Com o crescimento populacional e a ampliação das áreas a abastecer, a complexidade e dimensões dos sistemas tendem a crescer, principalmente se este crescimento não foi contemplado na fase de projeto. Considerando seus elementos de adução, reservação, bombeamento, manobras e distribuição, torna-se ainda mais complexo o controle operacional, face às decisões tomadas pelos operadores, baseadas na experiência, às situações em que tais decisões são necessárias e à sua repercussão operacional no sistema.

Um exemplo bastante crítico é o da Região Metropolitana de São Paulo (RMSP), que vem apresentando demandas superiores ou muito próximas à oferta, implicando na necessidade de uma operação otimizada para redução de deficits, atendimento à demanda e para adução de água de forma mais racional, uma vez que a capacidade de investimento em obras é limitada, conforme análises de Zahed Filho (1990); Cipparrone (1995); Gambale (2000) e Borges (2003).

Além do cenário do sistema de abastecimento local descrito acima, os problemas provenientes da redução da quantidade e qualidade dos recursos hídricos superficiais, cada vez mais distantes, tornam primordiais a eficiência e otimização das medidas de controle desde a captação, tratamento, adução e de perdas dos sistemas adutores urbanos.

O Sistema Adutor Metropolitano (SAM) que atende à RMSP, hoje opera com equipamentos de medição e controle comandados por telemetria, para o monitoramento de vazões, pressões, níveis e status de válvulas e bombas que compõem o sistema diretamente do 
Centro de Controle Operacional (CCO), através de sistema para monitoramento tipo SCADA (Supervisory Control and Data Acquisition).

Com os dados recebidos telemetricamente, esse sistema fornece condições para que o operador tome decisões acerca das regras de manobras, operacionalização e intervenção no sistema.

A falta de um sistema automático de controle é contornada atualmente graças às habilidades e experiências dos operadores, podendo haver eventualmente, controvérsias conseqüentes de atitudes conforme o operador, prejudicando a operação decorrente de uma visão limitada do comportamento da rede.

O estágio mais avançado da operação de um sistema de grande porte, exige mudanças ou adaptações de sistemas $S C A D A$ para outra, denominada controle automático por computador, que necessita de algoritmo de otimização e gerenciamento, associado à sistemas de monitoramento e modelos de simulação da rede e previsão de demandas.

A não-linearidade e a complexidade destes cenários fazem com que tecnologias tradicionais disponíveis para o tratamento analítico, como Programação Linear e Não-linear, Programação Dinâmica (BRION e MAYS (1991); PEZESHK et al. (1994); DIBA (1995); CIPPARRONE (1995); WATKINS e McKINNEY (1998), LABADIE, 2004) apresentem dificuldades de convergência, com grande tempo de processamento e sem a garantia do ótimo global quando aplicadas.

Dentre as técnicas de otimização disponíveis atualmente, os Algoritmos Genéticos (AG's) têm sido amplamente utilizados desde a sua criação por Holland (1975) nas mais diversas áreas do conhecimento, apresentando-se como uma meta-heurística robusta e poderosa de busca adaptativa, flexível e de fácil implementação, baseada na Teoria da Evolução de Darwin, com resultados significativos, inclusive aplicáveis para esse tipo de 
problema, dada a complexidade e dimensão do sistema e também, como ferramenta para tomada de decisões inerentes às situações e ambientes de um cenário desse porte.

Resta ainda a dúvida quanto à velocidade dos AG's na convergência e na definição da solução ótima, para avaliar sua adequação à operação em tempo real.

Assim, face ao cenário descrito, a presente pesquisa faz-se necessária, com a criação de algoritmo adequado às dimensões e complexidades de uma situação real, que minimize os problemas operacionais do sistema de abastecimento em questão, avaliando portanto, sua adequação à operação em tempo real.

Para a avaliação dos AG's como ferramenta de otimização de sistemas de abastecimento em tempo real, esta tese tem como objetivo a criação de um programa de computador que otimize a operação do SAM Leste da RMSP, que é parte do SAM, maximizando sua eficiência no que se refere à capacidade de reservação ótima ao longo do dia, contemplando os limites mínimo e máximo dos reservatórios, status operacional dos equipamentos de bombeamento, quantidade de manobras das válvulas de controle de vazão, os custos relacionados ao consumo de energia elétrica e garantindo o atendimento das demandas horárias requeridas.

O modelo otimizador a ser criado possuirá interfaces com sistema de monitoramento da rede tipo SCADA e a simuladores de rede (Epanet 2.0 - ROSSMAN (2000)). Serão utilizadas séries históricas a partir de 1997, consideradas como previsão perfeita de demandas da rede, de forma a produzir um algoritmo que auxilie na tomada de decisões operacionais em tempo real, reduzindo a interferência dos operadores apenas para situações extremas ou de pane. 


\section{REVISÃO BIBLIOGRÁFICA}

Nas últimas décadas, com o decréscimo da disponibilidade dos recursos hídricos, torna-se primordial a utilização consciente destes recursos. Para as empresas concessionárias do abastecimento de água das grandes cidades, conciliar o atendimento da demanda com a disponibilidade hídrica é tarefa ainda mais complicada, visto que as estações de tratamento de água e as fontes de abastecimento superficial estão cada vez mais distantes, com altos custos de adução e distribuição.

Muitos pesquisadores têm se voltado para esse tema, considerando inclusive os problemas relativos à otimização dos custos de projeto (CASTILLO; GONZÁLEZ, 1996; SMITH; WALTERS, 1998; MEIER; BARKDOLL, 2000; DRAPER et al. 2003) e à operação dos sistemas de abastecimento urbano contemplando objetivo único (BRION; MAYS, 1991; OLIVEIRA; LOUCKS, 1997; SAKARYA; MAYS, 2000; VAN ZYL, SAVIC; WALTERS, 2004) e multiobjetivo (HALHAL el al., 1997; SAVIC et al., 1997; CARRIJO, 2004; PRASAD; PARK, 2004).

Santana (1992) salienta que na década de 70, as preocupações nos estudos de redes hidráulicas eram relativos às soluções fundamentais dos sistemas de equações, baseadas no simples uso de ferramentas matemáticas.

Já nos anos 80, caracterizou-se uma consolidação das metodologias, tendo como preocupação primordial a comparação entre soluções otimizadas.

Finalmente, na década de 90, buscou-se um aperfeiçoamento dos algoritmos, procurando-se a consolidação teórica e provas para a solução adotada.

Ribeiro, C. (1985), salientava o fato de que muitos sistemas de abastecimento de água operados com sucesso há anos, quando submetidos a uma demanda crescente, 
apresentavam uma série de complicações operacionais que comprometem o abastecimento de água à população.

Em sua análise, o autor propôs o desenvolvimento de modelo matemático que permitiria, além da obtenção de esquemas operacionais para um dado perfil de consumo, analisar comportamento de diversos componentes de uma rede de água.

Segundo o autor em questão, o desempenho satisfatório destes sistemas era obtido graças à habilidade pessoal dos operadores, ao adaptarem programas operacionais inicialmente estabelecidos por projetistas, às novas condições de demanda. Afirmou ainda que a operação dos sistemas de água do futuro seria uma tarefa muito complexa a ser confiada à habilidade dos operadores, exigindo do engenheiro, o desenvolvimento de projetos nos quais os sistemas fossem operados de maneira previsível.

Algumas das complicações que surgiam, mencionadas por Ribeiro, C. (1985), devido às demandas crescentes de água eram:

- Rompimento de tubulações durante o período de partida de bombas;

- Impossibilidade de impor ao sistema, vazões para as quais foi projetado, comprometendo o abastecimento;

- Falhas nos mecanismos das válvulas automáticas de controle;

- Grande potencial de uma tubulação e a válvula associada para gerar ruídos e vibrações, danificando as tubulações e acessórios;

- Entrada de ar nas tubulações, formando bolhas e gerando golpes de aríete;

- Reservatórios instalados para atender emergências, impossibilitados de serem utilizados devido à cavitação nas válvulas;

- Válvulas que face às demandas crescentes passam a ser redimensionadas em seus tempos de manobras, etc. 
Estes exemplos, longe de esgotarem todas as possibilidades, ilustravam a complexidade operacional de uma rede de distribuição de água de grandes dimensões, exigindo sempre que possível operação automática.

Walski et al.(1987) comentam, em seu epílogo sobre as diferenças de modelagem de projeto de redes, e diversas técnicas de otimização de sistemas de abastecimento de água podem ajudar os engenheiros, no dimensionamento e operação ótimos dos sistemas adutores.

Com a continuidade do seu desenvolvimento, segundo os autores, os modelos deveriam ser capazes de solucionar mais porções desses sistemas e ser aplicáveis a sistemas maiores e mais complexos. Ainda existe um considerável número de engenheiros que avaliam sistemas de abastecimento de água através de critérios de desempenho. Isso cria, segundo Walski et al.(1987), dificuldades adicionais na determinação e verificação de uma solução ótima.

Para Tarquin e Dowdy (1989), existem duas razões que evidenciam a possibilidade de uma redução nos problemas com os custos operacionais em sistemas de adução de água:

$1^{\circ}{ }^{\circ}$ )Os projetos das redes são elaborados com vistas ao projeto ótimo atual, não observando as ampliações futuras e a eventual otimização do projeto no todo;

$2^{\circ}{ }^{\circ}$ ) Deficiências nas políticas de manutenção dos acessórios do sistema.

De acordo com Zahed Filho (1990), a operação de sistemas em tempo real, é uma tarefa bastante complexa, que vem recebendo atenção especial já há algum tempo, face à necessidade da garantir confiabilidade no atendimento dos serviços, economia no uso de equipamentos (energia elétrica e manutenção) e retardamento de investimento para expansão do sistema, mesmo que ainda seja pouco pesquisada. 
No planejamento da operação, requisito operacional fundamental segundo o referido autor, é preciso definir regras de controle do sistema, fixas ou variáveis, sendo necessárias três condições básicas:

$1^{\circ}$. Definição do objetivo a ser alcançado;

$2^{\circ}$. Disponibilidade de modelos matemáticos de análise e os equipamentos para processamento e,

$3^{\circ}$. Conhecimento do sistema.

As políticas operacionais da operação em tempo real, de acordo com Zahed Filho (1990), deveriam basear-se na informação atualizada sobre o status atual do sistema, disponibilidade de um modelo previsional de demanda de água, de simulação e de otimização. Um esquema básico para as políticas operacionais poderia ser da seguinte forma, conforme Figura 2.1:
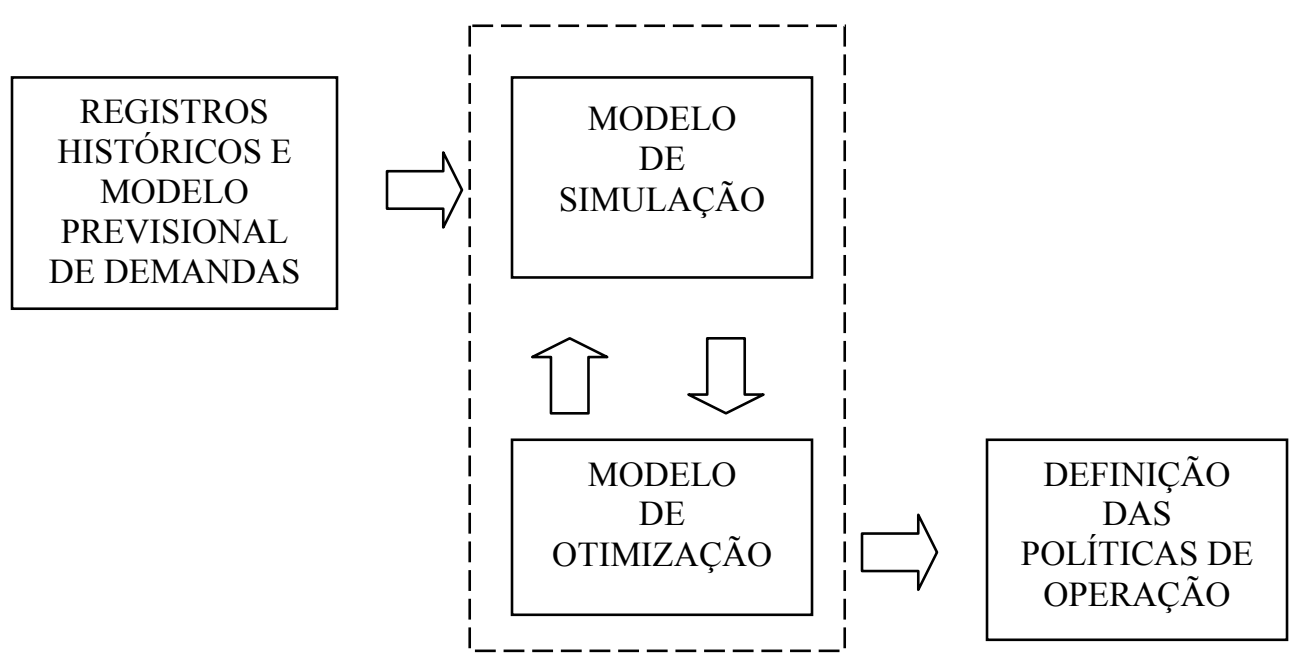

Figura 2.1 - Esquema de Definição de Políticas Operacionais 
Na Figura 2.1, o cadastro atualizado do sistema e os registros históricos alimentam o simulador do sistema e o desenvolvimento de sistemas especialistas, e desta forma, as experiências vividas no controle passam a ser integradas no software de decisão (modelo de otimização), definindo assim, as políticas operacionais que atendam os objetivos estabelecidos pelo planejamento.

Uma pesquisa efetuada pelo Comitê de Projetos de Sistemas de Distribuição de Água por Computador (CADIUS), conclui que em muitos sistemas existe a intenção de adotar uma operação controlada ou ao menos auxiliada computacionalmente (ZAHED FILHO, 1990). Tal tendência deve-se aos seguintes fatores:

- Crescente complexidade do sistema adutor, com um número maior de estruturas de controle e com nível de exigência de confiabilidade crescente;

- Substituição de operadores experientes, por novas equipes;

- Procura na redução de custos operacionais;

- Dificuldade no acompanhamento global do sistema, em horas de grande consumo e em situações críticas;

- Descontinuidade operacional ao longo do dia, quando há substituição das equipes.

- Eliminação do caráter subjetivo quanto a riscos operacionais;

- Necessidade de tempo para os operadores analisarem as regras operacionais e suas conseqüências ao sistema;

- Facilidade para captação de novos operadores e,

- Falhas mais freqüentes em sistemas antigos, que conduzem a decisões operacionais difíceis, que devem ser tomadas rapidamente e sob tensão. 
O estágio mais avançado de operação de um sistema de grande porte exige uma mudança de uma forma SCADA (Supervisory Control and Data Acquisition) de aquisição de dados para outra, denominada controle automático por computador, que exige um algoritmo de otimização associado a um modelo de previsão de demandas e a um simulador do sistema, em tempo real.

O grau de automatização é variável, dependente do porte do sistema adutor e de suas necessidades, comenta o referido autor. Os sistemas mais complexos tendem a evoluir de uma operação baseada em $S C A D A$ para a automática, de forma a liberar os operadores para tarefas apenas de supervisão, visando incrementar a confiabilidade operacional.

Mais recentemente, Francato (2002) comenta que com a possibilidade de execução de algoritmos matemáticos complexos em computadores pessoais, os profissionais podem detalhar os sistemas de maneira mais precisa, ficando mais próximo o equacionamento matemático da situação física real. Desse modo, pode-se dedicar mais tempo à análise da consistência dos resultados, estudos de novas formulações, rearranjo dos sistemas, medidas de reabilitação, etc.

Um fator complicante para a análise dos sistemas de recursos hídricos é o grande número de variáveis necessárias para que haja uma representação física fiel do problema. Em muitos casos, comenta Francato (2002), é necessário um processo de decomposição que proporcione a divisão de sistemas em subsistemas gerenciáveis. Outros problemas são os objetivos incomensuráveis ou não quantificáveis precisamente.

Simonovic (1998) ${ }^{1}$ apud Francato (2002), menciona que a aplicação da análise de sistemas deve seguir as seguintes etapas, para que se obtenha uma resposta eficaz:

a) Definição do problema;

b) Reunião dos dados envolvidos;

\footnotetext{
${ }^{1}$ SIMONOVIC, S.P. A systems approach to creative water resources engineering. Curso CTH-USP, 1998
} 
c) Desenvolvimento dos critérios para avaliação de alternativas;

d) Formulação de alternativas;

e) Avaliação de alternativas;

f) Seleção da melhor alternativa e,

g) Plano de implementação.

A Engenharia Hidráulica vem se preocupando em obter melhores resultados com o planejamento da operação de sistemas, trabalhando com técnicas de modelagem, para que se possa representar a rede hidráulica real, dentro um sistema de equações matemáticas que apresentem relações lógicas entre si.

Para Francato (2002), as técnicas de planejamento e operação de sistemas de abastecimento de água vêm sendo utilizadas há algum tempo em muitos países, principalmente devido à escassez de recursos hídricos. Além de necessitarem de técnicas de distribuição eficiente de água, necessitam ainda de políticas de controle e adequação ao consumo.

Por exemplo, a concessionária East Bay Municipal Utilities District (EBMUD) da Califórnia (EUA) atende 35 municípios, abastecendo uma população de 1,4 milhões de habitantes, numa área de $325 \mathrm{mi}^{2}$ (cerca de $842 \mathrm{Km}^{2}$ ) e uma demanda de 215 MGD $\left(9,43 \mathrm{~m}^{3} / \mathrm{s}\right)$.

O sistema adutor conta com 175 reservatórios, 5 (cinco) represas terminais utilizadas para regularização do abastecimento na primavera/inverno, 2 (dois) aquedutos (136Km), e 2 (duas) Estações de Tratamento de Água (ETA's).

A previsão de demanda obtida tem como base o crescimento populacional a partir de dados fornecidos pelas agências governamentais. A distribuição da água é feita por gravidade 
e não possui sistemas ou softwares que monitorem ou auxiliem no gerenciamento ou operação locais.

Na cidade de Seattle (EUA), a empresa Seattle Public Utilities (SPU) gerencia o sistema de abastecimento de água com 28 áreas geográficas dentro da cidade, atendendo 1.300.000 habitantes para demanda de $7,43 \mathrm{~m}^{3} / \mathrm{s}$. Possui duas fontes superficiais de captação, as represas dos Rios South Fork Tolt e Cedar e uma fonte subterrânea, de um campo de poços profundos, 17 estações de tratamento de água, 23 reservatórios, 9 (nove) linhas adutoras e ramais e 25 válvulas reguladoras.

Opera seu sistema de abastecimento desde 1998 com o sistema SCADA, a partir de um Centro de Controle Operacional, que varre toda rede a cada 15 segundos e armazena os dados em $C D-R O M$, com um sistema chamado $M A X I M O$ para manutenção e gerenciamento e um sistema de armazenamento e gerenciamento de dados de qualidade da água, chamado LIMS (Laboratory Information Management System).

Utilizam um modelo computacional com regras probabilísticas para previsão de precipitação e escoamento direto para as represas e um modelo de rebaixamento para utilização dos poços até um limite de segurança. A água explotada dos poços é tratada e adicionada à vazão aduzida da Estação de Tratamento de Água (ETA) da represa do Rio Cedar, quando o nível da represa chega a níveis muito baixos para a adução, durante os períodos de estiagem. O processo é invertido no inverno, quando o nível estático dos aqüíferos está baixo.

O planejamento do abastecimento é feito semanalmente, considerando a disponibilidade de água para adução e abastecimento, sua qualidade, a sazonalidade, demanda de água por zonas de serviço, limitações de capacidade de captação, tratamento, adução e abastecimento. 
A $S P U$ utiliza um modelo econométrico de previsão de demanda a longo prazo, baseado no consumo corrente/potencial por atacado e no crescimento populacional, classificando primeiramente a demanda em função do tipo de consumidor, e depois utilizando registros históricos, impacto das variações de consumo, edificação, estação do ano, número de categorias por setor, a demanda por setor da cidade é estimada.

A Companhia de Saneamento Básico do Estado de São Paulo (Sabesp), opera o Sistema Adutor Metropolitano de São Paulo (SAM), controlando a partir do Centro de Controle da Operação (CCO), a adução dos oito sistemas produtores com 8 (oito) ETA's que produzem aproximadamente $63 \mathrm{~m}^{3} / \mathrm{s}$ de água, para cerca de 19 milhões de habitantes em uma área de $8.500 \mathrm{Km}^{2}$. Possui 125 reservatórios setoriais e pontos de entrega, atendendo à demanda de consumos de água de $2,12 \times 10^{6} \mathrm{~m}^{3} /$ dia.

Atualmente, o sistema de controle é baseado em tecnologia $S C A D A$, recebendo informações de cerca de 130 estações remotas de telemetria, referentes a níveis de água armazenados nos reservatórios e torres, vazões e pressões em pontos estratégicos do sistema adutor e a posições de válvulas e estados de bombas.

Devido às crescentes interligações entre as adutoras e a implantação de melhorias no sistema adutor, as operações se tornaram cada vez mais complexas, fazendo-se necessária a adoção do sistema SCADA, que vem sendo utilizado desde 1980.

O sistema é do tipo centralizado, sendo controlado por técnicos em controle do abastecimento, que tomam suas decisões de manobras das válvulas e acionamento de bombas, baseados nas informações recebidas e apoiados em sua experiência adquirida na operação.

Atualmente, o sistema se classifica como centralizado, mas com "loop aberto", uma vez que as decisões operacionais são tomadas pela equipe de controle. Entretanto, como as decisões operacionais são subjetivas, o desempenho da operação fica condicionado diretamente à equipe que está ativa. O revezamento de equipe e mesmo sua substituição de 
tempos em tempos, aliada à complexidade crescente do sistema, exige a implantação de um sistema operacional, que se não for totalmente automático, ao menos seja um suporte confiável às decisões dos operadores.

\subsection{MODELOS DE SIMULAÇÃO}

A simulação pode ser definida como uma técnica em que se fazem analogias, conservando características físicas ou lógicas dos sistemas, objetivando conclusões através do modelo formulado. No caso dos modelos de simulação para análise de sistemas de recursos hídricos, a analogia é: equações matemáticas, que tentam expressar as relações do mundo real através do modelo matemático. A simulação difere da otimização por não apresentar natureza otimizante e sim, descritiva.

Os modelos de simulação fazem a representação de um sistema para prever o seu comportamento, sob um dado conjunto de condições iniciais, de contorno e operativas.

Com o advento dos computadores e da micro-informática, a simulação passou a ser atraente devido ao rápido desenvolvimento, nas últimas décadas, de hardware e software, permitindo sobremaneira a mudança rápida na configuração e representação dos sistemas e assim, comparações e análises relevantes dos resultados.

A modelagem da operação dos sistemas de abastecimento de água visa obter uma política operacional que nada mais é, do que um grupo de regras que agendam e indicam, quando os equipamentos de bombeamento devem ser ligados ou não, quais devem ser os percentuais de abertura das válvulas de controle ou qual política de esvaziamento e enchimento dos reservatórios deve ser adotada, etc. As regras são formuladas para determinado horizonte de planejamento, subdividido em intervalos discretos de operação. 
Cesario (1995) apud Meier e Barkdoll (2000), afirma que cerca de 86\% de todas as concessionárias de água do mundo utilizam modelos computacionais de redes para simular e analisar seus sistemas de distribuição de água. Esses modelos são usados em planos de expansão, questões de investigação de operação, planos de manutenção e custos operacionais estimados.

Somente nas últimas décadas é que se verifica uma preocupação com a operação de sistemas de reservatórios, inclusive em condições particulares como emergências, panes, situações de déficits, racionamento de energia elétrica, etc.

Yeh (1985) e Wurbs (1993) notam um espaço vazio contínuo entre as implementações desenvolvidas teoricamente e o mundo real. As possíveis disparidades, para Labadie (2004) incluem:

- Muitos operadores de sistemas são céticos quanto a modelos que proponham a substituição de seus julgamentos e prescrição de estratégias e sensibilidade “mais confortável" com o uso de modelos de simulação existentes;

- Limitações computacionais de software e hardware no passado requereram simplificações e aproximações que operadores são indispostos a aceitar;

Francato (2002) ressalta ainda que os modelos matemáticos apresentam três valiosas funções para análise de sistemas em recursos hídricos:

- Amplificação: uso de modelos que pode amplificar os conhecimentos disponíveis de um sistema complexo. Não produzem a informação, mas permitem sistematizar o tratamento desta informação;

- Organização: o modelo é capaz de fomentar e fornecer decisões em termos simples, mesmo que haja características de sistemas complexos; 
- Avaliação: se forem incorporadas algumas medidas de desempenho de sistemas nos modelos, introduz-se a habilidade desse modelo fazer comparações entre as soluções.

Assim, de acordo com o referido autor, os modelos matemáticos voltados para análises em recursos hídricos são, essencialmente, ferramentas para subsidiar os julgamentos, intuições e experiências dos profissionais da área.

$\mathrm{Na}$ literatura, é possível observar uma quantidade considerável de experiências bem sucedidas com modelos de simulação em recursos hídricos (GOULTER; COALS, 1986; GOULTER; BOUCHART, 1990; FUJIWARA; TUNG, 1991; PEZESHK et al., 1994; ORMSBEE; LANSEY, 1994; DIBA, et al., 1995; LUVIZZOTO JÚNIOR, 1995; WAGNER et al., 1998; SAKARYA; MAYS, 1998; MEIER; BARKDOLL, 2000; DRAPER et al., 2003; LABADIE, 2004).

Dentre os modelos de simulação mais conhecidos podem ser citados o HEC-RESSIM (Hydrologic Engineering Center), STELLA (High Performance Systems), POWERSIM (Powersim Inc.), VENSIM (Ventana Systems, Inc.), KYPIPE (WOOD, 1980) e EPANET (ROSSMAN, 2000) os quais têm sido rotineiramente aplicados por muitos anos em agências de desenvolvimento e planejamento de recursos hídricos.

Os modelos de simulação também podem ser utilizados para dar suporte à decisão, considerando o conhecimento prévio do comportamento do sistema em análise, de maneira que alterações na forma de análise de sensibilidade de parâmetros do tipo diâmetros e coeficientes de rugosidade de tubulações de uma rede, possam refletir em benefícios ou prejuízos, simulados pelos modelos simuladores de natureza descritiva, que possam dar suporte à decisão dos gestores destes sistemas. 
De acordo com Labadie (2004), muitos dos obstáculos para o gerenciamento dos sistemas de reservatórios estão sendo superados pela crescente aplicação do conceito de sistemas de suporte a decisão.

A incorporação inclusive da otimização nestes sistemas, têm reduzido a resistência ao seu uso, pela ênfase na otimização como ferramenta controlada pelos gerenciadores, que têm responsabilidade pelo sucesso ou falha do sistema em alcançar os objetivos definidos. Alguns exemplos de modelos de suporte a decisão (MSD) mais conhecidos são: MODSIM (LABADIE ${ }^{2}$ et al., 2000), CALSIM II (Califórnia Department of Water Resources), OASIS (Hydrologics, Inc.) e AQUANET (PORTO, 2003).

Luvizzoto Jr. (1995) elaborou um trabalho, utilizando o método elástico, como técnica para o desenvolvimento de rotinas computacionais, para análise operacional de redes hidráulicas de abastecimento de água em período extensivo (operação e controle).

Para o autor em questão, é inegável a tendência dos sistemas de abastecimento de água serem operados com o auxílio de computadores digitais, em virtude das atuais exigências de qualidade dos serviços com a minimização dos custos operacionais. Modelos matemáticos confiáveis para simulação operacional são necessários para esse fim. Para a investigação de regras de operação, são usualmente empregadas técnicas de otimização e de simulação contínua, ou ainda a combinação de ambas.

Ormsbee e Lansey (1994) analisaram as principais técnicas, levantando as contribuições mais relevantes para o estudo de sistemas de abastecimento. Comentam estes autores, que a escolha da técnica apropriada é dependente das características do sistema. Tentativas de incorporar o impacto da variabilidade espacial da demanda ou mudanças no status operacional dos vários componentes do sistema, normalmente requerem o uso de formulações alternativas. Para sistemas que contém um número razoável de bombas,

\footnotetext{
${ }^{2}$ LABADIE, J. et al. MODSIM: Decision support systems for river basin management. Documentation and user manual. Dept. of Civil Engineering, Colorado State Univ. Colorado, 2000.
} 
comentam Ormsbee e Lansey (1994), pode ser plausível utilizar um modelo que contemple a velocidade variável das bombas. Onde o número total de bombas é considerável, segundo os autores em questão, o uso de uma variável de decisão implícita ao controle do booster, pode ser mais apropriado.

Ormesbee e Reddy $(1995)^{3}$ apud Francato (2002) relatam que nos últimos anos, a modelagem de sistemas de abastecimento de água tem dado ênfase ao uso integrado on-line de computadores e tecnologias de controle, para impor operações em tempo real.

Sakarya e Mays (2000), apresentam uma análise para determinação de esquemas operacionais discretos de bombeamentos ótimos em um sistema hipotético, utilizando um simulador hidráulico de sistemas de distribuição de água, o Epanet (ROSSMAN, 1994), e um programa de otimização não-linear, o $G R G 2$, que minimiza os desvios das concentrações de substâncias reais dos valores desejados, tempos de operação totais dos grupos moto-bombas e o custo total de energia consumida, sujeitos às restrições hidráulicas, de qualidade da água e de contorno.

A solução ótima encontrada pela metodologia proposta na análise de Sakarya e Mays (2000), pode resultar em um tempo de operação dos equipamentos de bombeamento que pode causar excessivas manobras de liga/desliga desses equipamentos, não recomendados na práticos. Regras operacionais pré-definidas podem solucionar esses problemas, mas necessitariam de formulação de programação mista inteira e não-linear, diferente da apresentada por Sakarya e Mays (2000).

Draper et al. (2003) apresentam um modelo de otimização de engenharia econômica do maior sistema de abastecimento da Califórnia (EUA), com desenvolvimento, calibração, limitações e resultados preliminares. Os autores utilizam o modelo CALVIN (California Value Integrated Network), tem como base, dados existentes de modelos de simulação com registros

\footnotetext{
${ }^{3}$ ORMSBEE, L.E. \& REDDY, S.L. Nonlinear heuristic for pump operations. Journal of Water Resources Planning and Management. ASCE, 1995.
} 
históricos hidrológicos, valores econômicos para uso urbano e agrícola da água em locais diversos ao longo de toda rede e solver de otimização da rede $(H E C-P R M)$. Segundo os autores, o modelo ainda encontra-se em fase de desenvolvimento. Pretende-se ainda, incluir restrições de geração de energia hidrelétrica, controle de cheias e adaptá-lo a cenários de demandas crescentes.

\subsection{MODELOS DE OTIMIZAÇÃO}

Segundo Haupt e Haupt (1998) otimização é o processo de fazer algo melhorar. Consiste em tentar variações em um conceito inicial e usar a informação ganha, para melhorar o possível, a idéia.

Otimização é o processo de ajuste de entradas para características de um aparelho, processo matemático ou experimento para encontrar a mínima ou máxima saída ou resultado. A Figura 2.2 ilustra o conceito definido acima (HAUPT; HAUPT, 1998):

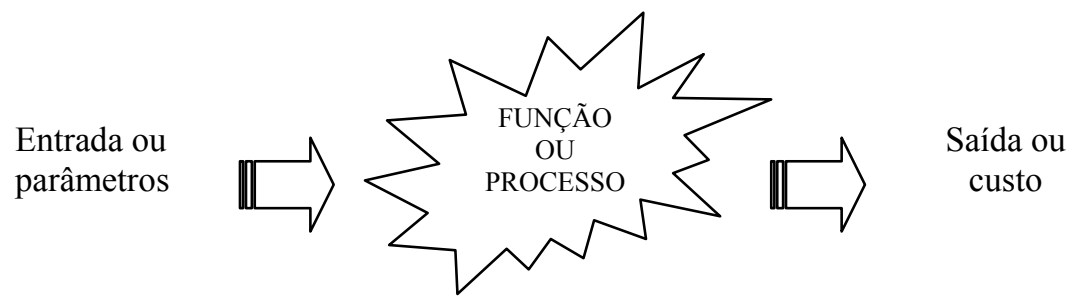

Figura 2.2 - Diagrama de uma função ou processo que é otimizado.

A entrada consiste em parâmetros, o processo ou função é conhecido como função de custo, função objetivo ou função de fitness, e a saída é o custo ou fitness. 


\subsubsection{CATEGORIAS DE OTIMIZAČ̃̃O}

A Figura 2.3 representa graficamente as categorias de otimização sugeridas por Haupt e Haupt (1998):

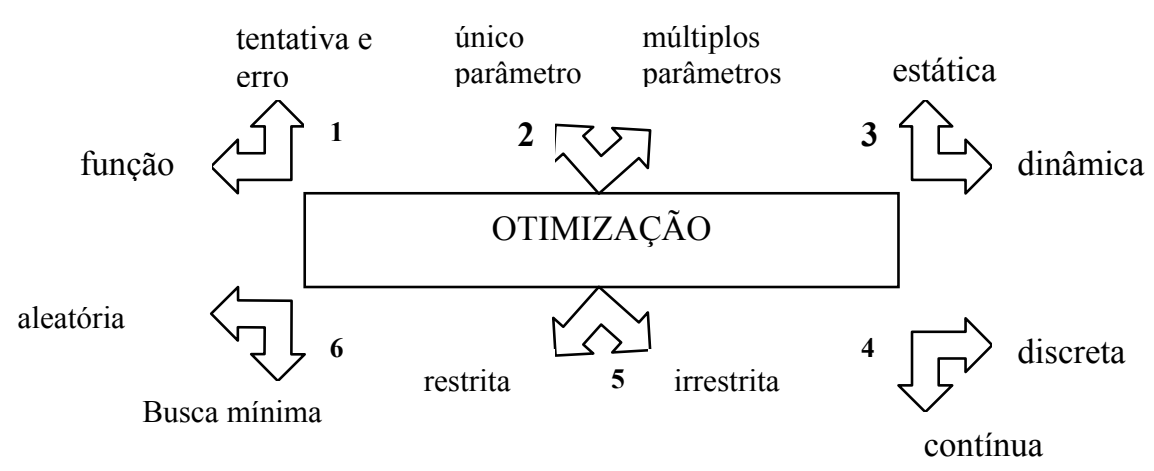

Figura 2.3 - Categorias de algoritmos de otimização

Fazendo uma breve descrição das categorias acima apresentadas, tem-se:

(1) Otimização por tentativa e erro refere-se ao processo de ajuste de parâmetros que afetam a saída sem conhecer muito sobre o processo (redes neurais artificiais, por exemplo) que produz a saída, sem envolver procedimentos de otimização propriamente dita.

(2) Se somente há um parâmetro, a otimização é unidimensional. Um problema que tem mais de um parâmetro requer otimização multidimensional. A otimização torna-se crescentemente difícil quando o número de dimensões cresce. Muitas técnicas de otimização multidimensional generalizam-se por séries de técnicas unidimensionais. 
(3) Otimização dinâmica significa que a saída é uma função do tempo, enquanto na otimização estática, a saída é independente do tempo. Quando se mora em subúrbios, por exemplo, existem muitas formas de dirigir para ir e voltar do trabalho. Qual é a melhor rota? Do ponto de vista da distância, o problema é estático e a solução pode ser encontrada usando mapas ou odômetro de um carro. Na prática, esse problema não é simples devido à grande quantidade de possíveis rotas. A rota mais curta não é necessariamente a mais rápida. Encontrar a rota mais rápida é um problema dinâmico cuja solução depende da hora do dia, tempo, acidentes, etc.

(4) Otimização pode ser classificada também como de parâmetros discretos ou contínuos. Os discretos têm somente um número finito de possíveis valores, enquanto que parâmetros contínuos têm um número infinito de valores possíveis. Se a decisão é em que ordem "se atacam" as séries de tarefas de uma lista, a otimização discreta é empregada. Otimização de parâmetros discretos é também conhecida como otimização combinatorial, porque a solução ótima consiste em certa combinação de parâmetros de um conjunto finito, de todos os parâmetros possíveis. Entretanto, se se tenta encontrar o valor ótimo de uma função $f(x)$ em uma linha de números, é mais apropriada a visão do problema como contínuo.

(5) Parâmetros freqüentemente têm limites ou restrições. A otimização restrita incorpora igualdades de parâmetros e desigualdades na função de custo. A irrestrita permite aos parâmetros ter qualquer valor. A otimização irrestrita trata de problemas de minimização ou maximização de funções sem qualquer restrição. Problemas de otimização restrita são tratados por técnicas de programação não-linear de otimização de uma função objetivo $f(x)$, na presença de restrições de igualdades ou desigualdades: 


$$
\max f(x)
$$

sujeito à

$$
\begin{aligned}
& \mathrm{g}_{\mathrm{i}}(\mathrm{x}) \leq 0 \quad \text { para } \mathrm{i}=1,2, \ldots, \mathrm{m}_{1} \\
& \mathrm{~h}_{\mathrm{i}}(\mathrm{x})=0 \quad \text { para } \mathrm{i}=\mathrm{m}+1, \ldots, \mathrm{m}(=\mathrm{m} 1+\mathrm{m} 2) \\
& \mathrm{x} \in \mathrm{X}
\end{aligned}
$$

onde:

$f, \mathrm{~g}_{1}, \mathrm{~g}_{2}, \ldots \mathrm{g}_{\mathrm{m} 1}, \mathrm{~h}_{\mathrm{m} 1+1}, \mathrm{~h}_{\mathrm{m} 2+2}, \ldots, \mathrm{h}_{\mathrm{m}}$ são funções de valores reais definidas em $\mathrm{E}^{\mathrm{n}}$

$x$ é um vetor $\mathrm{n}$-dimensional com componentes $\left(\mathrm{x}_{1}, \mathrm{x}_{2}, \ldots, \mathrm{x}_{\mathrm{n}}\right)$ que satisfazem as restrições e enquanto isso, minimiza $f$ (função objetivo);

$\mathrm{g}_{\mathrm{i}} \leq 0$ é restrição de desigualdade;

$\mathrm{h}_{\mathrm{i}}(\mathrm{x})=0$, restrição de igualdade;

$X$ pode incluir tipicamente limites inferior e superior das variáveis, usualmente chamado restrição de domínio. $\mathrm{O}$ vetor $x \in X$ satisfaz todas as restrições e é chamado solução viável para o problema.

Haupt e Haupt (1998) ressaltam que parâmetros restritos freqüentemente convertem-se em irrestritos através de transformação de variáveis. Muitas rotinas de otimização numérica funcionam melhor com parâmetros irrestritos. Resumindo, quando o problema de otimização restrita, é formulado em termos de equações e restrições lineares das variáveis de decisão, tem-se um problema a ser solucionado pela técnica de programação linear. Quando as equações de custo ou restrições são não-lineares, trata-se de um problema a ser resolvido pela técnica de programação não-linear.

(6) Alguns algoritmos realizam otimização a partir de um conjunto inicial de soluções. Essas técnicas de otimização facilmente são aprisionados em ótimos locais e tendem a 
ser rápidos. Eles são os algoritmos de otimização tradicionais e baseados em métodos de cálculo ou movimento de um conjunto de parâmetros para outro, baseado em alguma seqüência determinante de passos. Por outro lado, métodos aleatórios usam cálculos probabilísticos para encontrar um conjunto de parâmetros. Tendem a ser mais lentos, mas têm grande sucesso para encontrar um mínimo global.

Com o desenvolvimento da tecnologia e dos recursos da informática hoje, e sua disponibilidade no mercado, a representação mais realística e a aplicação das técnicas de otimização aos ambientes reais das mais diversas áreas do conhecimento, têm tido maior freqüência.

Os trabalhos de otimização em redes hidráulicas, citados adiante, têm formulado diversos objetivos como a minimização de custos de bombeamento, minimização das perdas por vazamento, otimização dos níveis de reservatórios, atendimento às demandas e principalmente, a operação ótima dos sistemas adutores e de distribuição de água.

Os problemas de otimização têm uma estrutura clássica, onde se procura minimizar ou maximizar a função objetivo, sujeita a um conjunto de condições de contorno, traduzidas na forma de equações, conhecidas como restrições.

Tanto a função objetivo quanto as restrições são funções matemáticas das variáveis de decisão. As variáveis de decisão definem como o sistema será operado, isto é, como será a manobra das válvulas, o nível dos reservatórios, o funcionamento dos grupos moto-bomba, etc.

Para aplicação de uma modelagem matemática em determinado problema, é necessário estabelecer relações lógico-matemáticas, a fim de representar o problema físico em sua versão matemática. 
Estas condições, afirma Francato (2002), são alcançadas através do estabelecimento de restrições que a solução deva respeitar e os objetivos que deva enfocar. A solução procurada é traduzida através do valor obtido nas variáveis de decisão.

Dependendo da natureza do relacionamento matemático entre os termos que compõem a função objetivo e as restrições, Francato (2002) classifica o modelo como:

- Linear: a função objetivo e todas as restrições são funções lineares das variáveis de decisão;

- Não-linear: a função objetivo ou algumas das restrições não apresentam relações lineares com as variáveis de decisão.

Quanto à incerteza sobre variáveis ou parâmetros, a natureza dos modelos classificase em:

- Determinísticos: se cada parâmetro ou variável possa ser assumido como valor fixo definido ou valores fixados para determinadas condições de contorno;

- Probabilísticos e/ou Estocásticos: possuem variáveis ou parâmetros sujeitos à incertezas.

Segundo a sua variabilidade temporal, os modelos podem ser ainda:

- Estáticos: as variáveis ou parâmetros não têm variabilidade temporal, não sendo, portanto, necessária a consideração do tempo na formulação do modelo;

- Dinâmicos: as variáveis têm dependência temporal, devendo ser considerada essa propriedade na formulação do modelo. 
Para Ormsbee e Lansey (1994), as restrições para problemas de sistemas de abastecimento de água podem ser divididas em três grupos:

- Limitações físicas dos sistemas (capacidade dos reservatórios, capacidade dos mananciais, configuração dos equipamentos de bombeamento, etc.);

- Leis Físicas (conservação de massa e conservação de energia);

- Solicitações externas (definição da demanda, manutenção aceitável dos níveis de pressão, etc.).

Na opinião de Labadie (2004), na atualidade, a situação dos modelos de otimização em relação à sua aplicação na solução dos problemas operacionais dos sistemas de abastecimento é:

- Os modelos de otimização seriam mais complexos matematicamente que modelos de simulação e por isso, mais difíceis de compreender;

- Modelos de otimização não incorporam riscos e incertezas;

- A enorme variedade de modelos de otimização criam confusão sobre qual selecionar para uma aplicação em particular;

- Alguns métodos de otimização como, por exemplo, a programação dinâmica, freqüentemente necessitam de desenvolvimento de código-fonte customizado e,

- Muitos métodos de otimização podem produzir somente soluções ótimas em vez de produzir regras úteis de operação condicional.

Ao resolver o problema de otimização, o modelo visa obter, dentre as soluções viáveis, a solução ótima ou cenário de soluções que atinjam o ótimo global, respeitando critérios pré-estabelecidos. 
Segundo Barr et al. (1995), os métodos heurísticos (também chamados algoritmos de aproximação, procedimentos inexatos ou simplesmente, heurísticas), vêm do grego "heuriskein" que significa descobrir, é um conjunto de passos bem definidos para identificar rapidamente uma solução de alta qualidade para um problema, cuja solução é um conjunto de valores desconhecidos para o problema e a "qualidade" é definida por um critério ou avaliação métrica padrão.

Métodos heurísticos são usados muitas vezes para identificar soluções de problemas, para os quais o tempo de obtenção é mais importante que a qualidade da solução. Barr et al. (1995) classificam a heurísticas nas categorias: construção, melhoria, programação matemática, decomposição, partição e restrição do espaço de soluções.

Até os anos 60 do século XX, foram os períodos prósperos da Pesquisa Operacional, com o surgimento de técnicas consagradas como os métodos Simplex, Kuhn-Tucker, as heurísticas e os métodos como a Programação Linear (PL), Programação Não-Linear (PNL) e Programação Matemática (Branch-and-Bound).

Já da década de 70, a Teoria da Complexidade foi um divisor de águas na Pesquisa Operacional e as heurísticas ganharam mais interesse. As heurísticas podem ser diretas ou mais complexas. Os algoritmos diretos ou heurísticas de melhoria tendem a possuir regras mais bem definidas como métodos de busca local em vizinhança, de subida e de descida, que param num ótimo local. Algoritmos mais complexos podem não possuir regras padrão de parada e buscam tipicamente por soluções melhores até um ponto arbitrário de parada ser alcançado.

Na década de 80 surgem as meta-heurísticas, como a Busca Tabu, Algoritmos Genéticos, Redes Neurais, Simulated Annealing, e GRASP, que são exemplos de algoritmos mais complexos, sendo aplicados a problemas com comportamento não-linear e de grandes dimensões. 
A Programação Inteira (PI) é um método que se insere na linha de otimização combinatória, que é o estudo matemático que visa encontrar o melhor arranjo, agrupamento, ordenação ou seleção de objetos discretos, sendo aplicável a problemas formulados com variáveis inteiras. Existem os problemas inteiros mistos (lineares), puros e tipo zero-e-um (ou binários). As técnicas de otimização combinatória procuram identificar uma solução que otimize uma função objetivo sobre um conjunto combinatorial de soluções factíveis. Destacase ainda a Programação Dinâmica (PD) e as combinações entre essas técnicas mencionadas acima, conhecidas como híbridos.

Para Goldbarg et al. (2000), as heurísticas são métodos de busca conhecidos como “míopes” ou "gulosos”, devido à sua pouca habilidade de atingir ou ficar próximos da solução ótima, pois dependendo da solução inicial, podem ficar limitadas a um espaço de busca local e não melhoram a solução.

Cipparrone (1995), em sua análise para otimização do controle operacional de sistemas hidráulicos complexos, utilizando o Método de Teoria Linear (Linear Theory Method) no desenvolvimento do simulador da rede, e a tecnologia Simulated Annealing, para otimização do sistema estudado aplicado à Alça Leste do SAM, conclui que devido ao número explosivo de variáveis e restrições intrínsecas ao problema de otimização, foi necessário criar um método operante de maneira mista matemático-heurística para manipulação do problema, em decorrência de suas dimensões.

Outros métodos de otimização amplamente aplicados são as meta-heurísticas. São técnicas mais robustas que não se limitam a um espaço de busca local e que, se não o atingem, ficam muito próximas do ótimo global ou da solução ótima (LAGUNA, 1995; JAMES, 1997; GOLDBARG; LUNA, 2000). 
Dentre as meta-heurísticas mais consagradas estão os Algoritmos Evolucionários, que são sistemas computacionais de solução de problemas baseados na evolução natural (HOLLAND, 1975; GOLDBERG, 1987; GEN; CHENG, 1997).

A variedade dos Algoritmos Evolucionários desenvolvidos (Programação Evolutiva, Programação Genética, Classificadores Genéticos e Algoritmos Genéticos) oferece uma característica conceitual comum, de simular a evolução de estruturas individuais, através de processos de seleção, mutação e recombinação. O processo depende do desempenho apresentado pelas estruturas individuais definidas pelo ambiente.

Os Algoritmos Genéticos (AG’s), apresentados mais detalhadamente no capítulo 3, são os mais populares dos Algoritmos Evolucionários. Savic et al. (1997) afirmam que os principais campos de aplicação dos AG's incluem problemas com alto grau de complexidade, propriedades e comportamento não-lineares, mostrando-se eficientes quando implementados em problemas de otimização com dimensões significativas, além das características acima ressaltadas, como é o caso da operação dos sistemas adutores de água.

De fato, os AG's têm demonstrado sua capacidade em tratar um grande número de estudos empíricos e analíticos, como por exemplo, aplicações incluindo programação e seqüenciamento, projetos de confiabilidade, programação e rotas de frotas, tecnologia de grupo, organização de layouts e locações, finanças, operação de sistemas de abastecimento elétrico (MIRANDA et al. 1998), sistemas produtivos (LI; ARGGAWAL, 2000), e tratamento de resíduos líquidos e sólidos (CHANG; WEI, 2000).

Os AG's derivam seu comportamento de uma metáfora de alguns mecanismos da evolução natural, e em essência, são procedimentos através dos quais uma população de strings é transformada pelos três operadores genéticos: seleção, cruzamento e mutação, durante o processo evolutivo. 
Cada cromossomo representa uma solução possível para o problema que está sendo otimizado e é formado por bits. Cada bit ou grupo de bits representam o valor de uma variável do problema (gene). Um cromossomo representa um indivíduo ou solução.

Essas soluções são classificadas de acordo com uma função de avaliação, função objetivo ou ainda, função de aptidão (fitness), produzindo os melhores valores ou cenário das melhores soluções.

Cada solução é avaliada pela função de aptidão de acordo com o valor resultante da função.

O operador seleção cria uma nova população (ou geração de indivíduos), pela cópia ou reprodução dos indivíduos mais adaptados da população anterior, selecionados de acordo com os valores de aptidão.

O operador cruzamento ou recombinação é o operador que troca partes do cromossomo e é executado com freqüência controlada por uma probabilidade de cruzamento.

O operador mutação consiste na mudança aleatória de parte do string representante do indivíduo (normalmente, trocando 1 bit). Esse operador deve ser usado com cuidado, à baixa probabilidade. Algumas informações genéticas importantes (valores de bits ou genes) podem ser perdidos durante o processo evolutivo e a mutação pode trazê-los de volta, se necessário. Não obstante, uma mutação com alta probabilidade pode ser danosa, conduzindo à busca aleatória independentemente da probabilidade de cruzamento.

Os AG's operam segundo um princípio de funcionamento muito simples: primeiro é gerada aleatoriamente a população inicial de soluções, sendo avaliadas pela função de aptidão. $\mathrm{O}$ funcionamento segue com a criação de uma nova população, aplicando-se o operador evolutivo seleção e os operadores genéticos cruzamento e mutação. 
No caso de aplicação em recursos hídricos, dada a sua comprovada robustez e eficiência segundo a literatura especializada, os AG's têm apresentado resultados significativos.

Simpson et al.(1994) fazem uma comparação de técnicas de otimização em redes de distribuição de água com os AG’s.

Reis; Porto e Chaudhry (1997) aplicam os AG’s na locação ótima de válvulas redutoras de pressão em sistemas de abastecimento urbano de água.

Savic e Walters (1997) e Gupta e Khanna (1999) aplicaram os AG's para minimizar os custos de projeto de redes de distribuição (estudo de caso), mostrando também que essa técnica é eficiente para manipulação de problemas deste tipo.

Halhal et al. (1997) descreveram uma técnica mutiobjetivo, usando custos de investimento e benefícios como duplo objetivo para o problema de reabilitação de redes, introduzindo os AG's estruturados desenvolvido por eles, e comparando com o AG padrão. Concluíram que os resultados obtidos com AG estruturado são melhores que o AG padrão para grandes redes. AG's estruturados, segundo os autores, são AG's que utilizam strings que aumentam de tamanho com o decorrer da evolução genética e incorporam conceitos do Messy Genetic Algorithm (GOLDBERG, 1987).

Oliveira e Loucks (1997) utilizaram os AG's para avaliar regras operacionais para sistemas de multi-reservatórios, demonstrando que essa técnica pode ser aplicada para identificação de políticas operacionais eficientes. Benefícios significativos foram observados na definição e avaliação de políticas operacionais otimizadas pelos AG’s.

Em sua pesquisa, Castillo e González (1998) sugerem um modelo de otimização de redes de distribuição utilizando os AG's, cujo objetivo é obter a solução de projeto com diâmetros ótimos das adutoras, acessórios e boosters, do ponto de vista econômico, no sistema de abastecimento hipotético proposto por eles. 
Walters et al. (1998) e DeShaetzen et al (1998) reforçam o desempenho dos AG's, apresentando metodologias para minimização dos custos operacionais de sistemas de abastecimento de água, relativas à operação e estratégias operacionais ótimas de equipamentos de bombeamento da captação de águas subterrâneas, através de poços tubulares e da operação da rede aplicadas a sistemas hipotéticos e de dimensões reduzidas.

Miranda et al. (1998) apresentam, de forma didática, em seu trabalho, uma revisão geral sobre os Algoritmos Evolucionários, sua classificação e exemplos de aplicação em sistemas elétricos, eletrônicos e campos afins como processamento paralelo, geraçãotransmissão-distribuição-operação de energia, análise, controle e fontes de energia elétrica e hidrotérmica, etc.

Wardlaw e Sharif (1999) apresentam uma avaliação de diversas formulações de AG’s para operação ótima de sistemas de reservatórios, utilizando um problema determinístico de horizonte finito de 4 (quatro) e 10 (dez) reservatórios, com vistas a fornecer diretrizes fundamentais para sua implementação em problemas práticos.

Wardlaw e Sharif (1999) concluíram que a técnica mais promissora de AG’s para o problema de reservatórios estudado compreende a codificação de valores reais, seleção tipo torneio, cruzamento uniforme e mutação uniforme modificada. A codificação de valores reais permite mais rapidez que a codificação binária e produz melhores resultados, inclusive o ótimo global. Os resultados demonstram que os AG's poderiam ser usados satisfatoriamente na operação otimizada de sistemas em tempo real, com entradas de dados geradas estocasticamente. Os referidos autores ressaltam ainda que os AG's têm potencial como alternativa para técnicas de programação dinâmica estocástica.

Em pesquisa recente, Ribeiro, G. (2000) utiliza os AG's para avaliar os custos totais de produção de águas subterrâneas do sistema de abastecimento da cidade de Araraquara/SP, considerando os custos de investimento de construção dos poços tubulares, de energia elétrica 
consumida pelas bombas submersas e estações elevatórias, custos de tratamento de água e mão-de-obra. Esta pesquisa mostrou a viabilidade e eficiência desse algoritmo quando aplicado a um sistema real complexo, de grandes dimensões e de natureza não-linear.

Meier e Barkdoll (2000) apresentam o uso de AG's, desenvolvido com interface com o simulador hidráulico Epanet, para otimizar um projeto de amostragem para modelo de calibração de rede, aplicado em uma pequena cidade de Ohio, com 6.000 habitantes, ajustando parâmetros de rugosidade dos tubos até o modelo, com 400 tubos e 350 nós, prever resultados de séries de testes de vazão. Os resultados obtidos mostraram que é uma ferramenta que ajudará os engenheiros a realizar o aproveitamento recional dos seus recursos disponíveis e apresentar benefícios e recursos adicionais, principalmente relativos a projetos de localização dos testes de vazão para calibração da rede e aos custos associados.

Smith e Walters (2000) comentam que os custos de construção e operação de sistemas de abastecimento de água geralmente são funções complexas, relacionadas às dimensões da rede, de tal forma que é impossível utilizar algoritmos convencionais na sua otimização, seja de custos construtivos ou operacionais. Os autores apresentam um método baseado nos AG's para identificar o desenho da rede ótima e sua dimensão, em termos da vazão de saída da estação de tratamento.

Gambale (2000) também utilizou os AG's na calibração de redes de água, mas na definição dos coeficientes de rugosidade em um sistema hipotético de pequenas dimensões. $\mathrm{O}$ autor sugere pesquisas mais aprofundadas no que se refere a diferentes funções de aptidão, sistemas de maiores proporções para a verificação mais ampla da influência da quantidade de pontos monitorados na eficiência da calibração e calibração de demandas nodais. Para Gambale (2000) a utilização dos AG's, em sua simplicidade, instiga o espírito de investigação e criação do aplicador na gama ilimitada de situações e de simples aplicações. 
Ilustrando a flexibilidade de aplicação, Chang e Wei (2000) utilizam os AG's, com vistas a otimizar rotas e locar estações de reciclagem em áreas urbanas, para solucionar um modelo de programação multiobjetivo fuzzy, inteira e não-linear. Entretanto, comentam ainda, na aplicação ao mundo real, não existe nenhum sistema ideal que funcionaria na sua área de estudo e que estratégias corretas e estações bem definidas garantiriam um sistema "trabalhável” inicialmente. Concluem que os AG's são ferramentas eficientes, na identificação das melhores rotas e previsão de estações de coleta de resíduos em áreas urbanas.

Para Reis e Akutsu (2002), o crescente emprego das técnicas inspiradas em mecanismos robustos da natureza vem trazendo à tona os AG's como ferramenta alternativa na resolução de tais problemas. Entretanto, comentam, diversas são as possibilidades de tratamento do mesmo problema via $\mathrm{AG}$ 's, tendo em vista a variedade de possíveis implementações que lhes é característica, além da possibilidade de hibridização com técnicas de programação matemática convencionais, reduzindo o tempo computacional na busca de soluções.

O trabalho de Reis e Akutsu (2002), revisa a literatura pertinente na resolução do problema de operação de reservatórios via AG's e discute as potencialidades do método, através de um exemplo de aplicação simples para um sistema hidrotérmico hipotético composto por quatro usinas hidrelétricas.

Cui e Kuczera (2003) apresentam um trabalho em que propõem a otimização de sistemas de abastecimento urbano utilizando métodos de busca probabilísticos, sendo utilizados os AG's e o método evolutivo complexo combinado (Shuffled Complex Evolution Method). Este último combina estratégias determinísticas e aleatórias, conceitos de busca aleatória controlada e evolução competitiva. Dentre as duas técnicas, os AG's prevaleceram por sua vantagem inerente de processamento em computadores paralelos. Os autores também 
inovam na utilização de dois operadores genéticos pouco conhecidos: a inversão e estratégia de seleção populacional.

Segundo o operador inversão, dois bits do cromossomo são escolhidos aleatoriamente, de acordo com uma probabilidade de inversão definida pelo usuário, de forma a beneficiar parte do string que, contendo informações genéticas a serem mantidas, mantenhase preservado ao longo do processo evolutivo.

$\mathrm{Na}$ estratégia de seleção populacional, o operador busca entre pais e descendentes da população os melhores indivíduos, para fazer parte da próxima geração. Este operador é aplicado após o operador inversão.

Tolson et al. (2004) sugerem uma técnica de otimização baseada na confiabilidade das redes de distribuição de água de atender ao consumidor, utilizando os AG's como ferramenta otimizadora com link para o método de confiabilidade de primeira ordem (First Order Reliability Method - FORM) proposto em sua análise, estimando a capacidade de confiabilidade da rede. Utilizam a técnica relativamente nova de AG's binário chamada de MicroGA (KRISHNAKUMAR ${ }^{4}, 1989$ ), aplicando a estratégia de mini-elitismo, seleção por torneio, cruzamento uniforme e mutação do tipo creeping, reiniciando as 5 melhores soluções com o securGA aplicando os mesmos operadores do MicroGA.

Na mutação tipo creeping, dois bits vizinhos trocam de lugar entre si com uma dada probabilidade.

Na opinião de Van Zyl; Savic e Walters (2004), os AG's se aplicam bem na otimização da operação de sistemas de distribuição, especialmente os complexos e de grandes dimensões. Os AG's, observam os autores, tem boas características de convergência inicial, mas com lentidão considerável, uma vez que a região de solução ótima tenha sido

\footnotetext{
${ }^{4}$ KRISHNAKUMAR, K. Micro-genetic algorithms for stationary and non-stationary function optimization. Proceeedings SPIE: Intelligent Control and Adaptive Systems, p.289-296, Philadelphia, PA, 1989.
} 
identificada. Neste estudo, a eficiência da otimização operacional via AG's foi melhorada através de um método híbrido, que combina os AG's com heurísticas de subida íngreme.

Para os autores em questão, estas tecnicas de busca local complementam os AG's com sua eficiência para encontrar o ótimo local. Van Zyl; Savic e Walters (2004) investigaram dois métodos: Hooke \& Jeeves e Fibonacci. Mostraram que o método híbrido AG - Hooke \& Jeeves, é superior ao AG puro na obtenção da boa solução rapidamente, ambos aplicados a um problema teste e a um sistema real, complexo e de grande dimensão.

Como se pode observar, a preocupação da comunidade científica com essa problemática de otimização de projetos, construção e operação de sistemas adutores de água é evidente e bem atual.

Labadie (2004) comenta que existem poucas áreas da aplicação de modelos de otimização de história tão rica ou mais diversa que a otimização de sistemas de reservatórios.

Embora oportunidades para aplicações aos problemas do mundo real sejam diversas, atuais implementações permanecem limitadas. O referido autor está convencido que as chaves para o sucesso na implementação de sistemas de reservatórios são:

(a) aumentar os níveis de confiança para um envolvimento mais interativo dos decisores no desenvolvimento destes sistemas;

(b) pacotes computacionais com melhor desempenho;

(c) interface melhorada com os modelos de simulação, os quais os operadores aceitam mais prontamente $\mathrm{e}$,

(d) a aplicação das meta-heurísticas é particularmente importante, adotadas devido sua robustez. A habilidade dos AG's, analisa Labadie (2004), de serem conectados diretamente a modelos de simulação é uma grande vantagem. 
Para Van Zyl; Savic e Walters (2004), o problema de encontrar a estratégia ótima de operação está longe de ser trivial: ambos custos de eletricidade e demandas da rede podem variar através de um ciclo típico de operação, níveis mínimos de água devem ser mantidos nos reservatórios para garantir confiabilidade do abastecimento e o número de acionamentos dos grupos moto-bombas deve ser limitado, no sentido de limitar os custos de manutenção excessivos.

Os autores comentam ainda que, além dos fatores acima expostos, está o fato do comportamento hidráulico dos sistemas de abastecimento de água ser altamente não-linear, tornando a modelagem computacional um processo complexo e de grande consumo de tempo. Finalmente, o número de possíveis estratégias operacionais torna-se vasta para sistemas com mais do que algumas bombas e reservatórios.

Carrijo (2004) desenvolveu um modelo computacional multiobjetivo com vistas a controlar a operação otimizada de sistemas de macro distribuição na cidade de Goiânia. Foram utilizados o simulador Epanet 2.0 e os AG's, considerando dois objetivos (custos de energia elétrica e benefícios hidráulicos) e um algoritmo de aprendizado de máquina, para extração de regras operacionais para o sistema. Segundo Carrijo (2004), os resultados demonstraram que podem ser produzidas estratégias operacionais satisfatórias para o sistema.

Assim, face ao cenário de escassez crescente dos recursos hídricos e ao acima descrito, mais e mais esforços devem ser feitos no sentido de obterem-se subsídios e técnicas, capazes de auxiliar os engenheiros na sua tarefa diária, de utilizar de maneira ótima os mananciais para atendimento das demandas hídricas, operar os sistemas de abastecimentos de água, e conciliar a disponibilidade do insumo básico, que é a água, com baixos custos e eficiência destes sistemas adutores e seus componentes. 


\subsection{MODELOS DE PREVISÃO DE DEMANDA}

No Brasil, em 1986, houve uma tentativa de desenvolvimento de modelo previsional de demandas em tempo real pela Companhia de Saneamento Básico do Estado de São Paulo (Sabesp), com apoio de empresa de consultoria, comenta Zahed Filho (1990).

Esta tentativa consistiu em apresentar uma solução simples e eficaz, baseada no princípio de obtenção de um desvio mínimo entre a vazão de consumo estimada e a observada. Entretanto, face à dificuldade na aquisição de dados, não se obtiveram resultados conclusivos utilizáveis na operação em tempo real.

Francato (2002) comenta que a previsão de demanda é um passo fundamental para que se possa obter uma política operacional do sistema de abastecimento, principalmente para operações em tempo real.

Zahed Filho (1990) propôs um modelo que tinha por objetivo o atendimento dos seguintes requisitos básicos:

(a) previsão de resultados compatíveis com desvios aceitáveis de operação,

(b) simplicidade de processamento e,

(c) flexibilidade de implementação de correções.

Para o propósito de previsão, de acordo com o autor em questão, a demanda pode ser considerada como uma combinação de duas componentes: a primeira, tendência de longo prazo, incluindo crescimento econômico, variações sazonais e periodicidades, e a segunda, incluindo componentes de variações diárias e horárias, oriundas das flutuações das condições climáticas. 
Para Zahed Filho (1990), é muito mais interessante, definir uma regra (subjetiva do operador) do que se alcançar a previsão "perfeita". As modificações das regras de operação em tempo real podem ser efetuadas a intervalos horários ou menores. É necessário que o tempo de processamento do modelo previsor seja compatível com os intervalos de operação, exigindo modelos simples e rápidos.

Na opinião de Ormesbee e Lansey (1994), a previsão de demanda deve empregar 3 (três) passos:

(a) a previsão diária de demanda;

(b) a demanda distribuída espacialmente associada aos nós da rede e,

(c) a distribuição de demanda durante o horizonte de planejamento.

A procura por um horizonte de previsão maior que a base diária é justificada, de acordo com Zahed Filho (1990), apenas com o objetivo de se minimizar o número de manobras nas válvulas e estações elevatórias do sistema. O horizonte mínimo de previsão deve sempre estar associado, ao tempo necessário para que se efetue novo processamento do modelo de otimização de manobras, implantação de novas manobras e que o sistema responda às alterações.

León et. al. (2000) desenvolveram um sistema especialista híbrido chamado EXPLORE para gerenciar o sistema de abastecimento de água de Sevilha, Espanha. No protótipo, utilizou-se o software especialista para aquisição de dados e gerenciamento de regras operacionais $A R T^{*}$ Enterprise (Brightware Corp.). O sistema adutor, cuja rede é dividida em 3 setores, capta $50.000 \mathrm{~m}^{3} / \mathrm{h}$ de água bruta e trata $864.000 \mathrm{~m}^{3} /$ dia, para 1 milhão de habitantes. Dentre as dificuldades encontradas observa-se a dependência das demandas de água, que segundo os autores é o maior fator incontrolável. 
O sistema EXPLORE reduz os custos operacionais de bombeamento de água para os diversos reservatórios, empregando a previsão de demanda para obter o esquema ótimo de operação diário de bombeamento, a partir do status da rede, de forma que o sistema de abastecimento opere corretamente.

O EXPLORE não faz uso dos registros históricos devido à dificuldade para manipulação de grande quantidade de dados. A previsão de demanda é feita, utilizando as demandas do mesmo dia da semana anterior, consideradas como previsão perfeita e seguindo um ciclo semanalmente repetitivo. De acordo com León et al. (2000), a precisão da técnica previsonal é calculada comparando a demanda prevista pelo modelo com os valores registrados diariamente, durante um intervalo longo de tempo, para que os resultados sejam significativos estatisticamente. Os autores sugerem, como melhoria para o método de previsão de demanda, a utilização de séries temporais, modelos de regressão ou técnicas estocásticas.

Zahed Filho (1990) comenta que o controle automático dos sistemas demonstra, em certos casos, a redução dos custos operacionais e aumenta a segurança e a confiabilidade, permitindo obter dados essenciais para o planejamento futuro do sistema.

A literatura consultada mostra que ainda há muito a ser feito com relação à operação de sistemas de grande porte, de forma automatizada e em tempo real, com métodos que forneçam suporte à decisão para quem opera a rede no menor tempo possível, que seja autosuficiente para gerenciar, decidir e operá-la com interferência mínima dos operadores.

Mostra-se necessária então, a proposta desta pesquisa, pretendendo-se desenvolver um modelo que verifique a viabilidade dos AG's como otimizador da operação do SAM Leste do SAM em tempo real, maximizar a eficiência operacional para atendimento da demanda local e, minimizando os custos de energia elétrica dos boosters e estações elevatórias, dessa área da Região Metropolitana de São Paulo (RMSP). 


\section{INTRODUÇÃO AOS ALGORITMOS GENÉTICOS}

Segundo Gen e Cheng (1997), desde os anos 60, existe um crescente interesse em imitar os seres vivos para solucionar problemas de difícil otimização. A simulação do processo evolucionário natural dos seres humanos resultou em uma técnica estocástica de otimização chamada ALGORITMOS EVOLUCIONÁRIOS, os quais freqüentemente superam os métodos convencionais de otimização, quando aplicados aos difíceis problemas do mundo real.

De acordo com Miranda (1998), os Algoritmos Evolucionários mais populares são:

- Programação Evolucionária;

- Estratégias de Evolução;

- Sistemas Classificadores, e

- Algoritmos Genéticos (AG’s);

Atualmente, os Algoritmos Genéticos são os mais amplamente difundidos e aplicados, que modelam o processo biológico para otimizar funções complexas.

O método foi desenvolvido por John Holland em 1975 durante o curso dos anos 60 e 70, e finalmente popularizado por um de seus estudantes, David Goldberg, que foi capaz de solucionar um problema difícil, envolvendo controle na transmissão de uma tubulação de gás para sua dissertação de mestrado (GOLDBERG, 1989). 


\subsection{TERMINOLOGIA}

Os AG's têm suas raízes na genética natural e na ciência computacional e por isso, o vocabulário utilizado na literatura dos AG's é uma mistura entre o natural e o artificial.

A Tabela 3.1 apresenta de forma sucinta a analogia feita com a terminologia genética natural e a sintética (AG's), sugerida por Gen e Cheng (1997):

Tabela 3.1 - Terminologia dos AG's

\begin{tabular}{|l|l|}
\hline Denominação Genética & Denominação Análoga \\
\hline Cromossomo (indivíduo) & Solução do problema \\
\hline Genes (bits) & Unidades formadoras da solução \\
\hline Local ou Locus & Posição do gene no string \\
\hline Genes alelos & Valores de fato da variável de decisão \\
\hline Fenótipo & Solução decodificada (Ex: $010=>156)$ \\
\hline Genótipo & Solução codificada (Ex: $156=>010)$ \\
\hline
\end{tabular}

Em um organismo biológico, a estrutura que "dá a receita" de como o organismo deve ser construído é chamado cromossomo. Um ou mais cromossomos são necessários para formar um organismo completo. O conjunto completo de cromossomos é chamado genótipo e o organismo resultante de muitos genótipos é chamado fenótipo. Cada cromossomo compreende um conjunto de estruturas individuais chamadas genes. Cada gene possui uma característica particular do organismo e a localização ou locus do gene dentro da estrutura do cromossomo, determina qual característica particular o gene representa.

Em um locus em particular, um gene pode ter valores diferentes da característica representada por ele. Os diferentes valores de um gene são os alelos. 
Na Figura 3.1 observam-se graficamente alguns dos termos acima explicitados (GEN; CHENG, 1997):

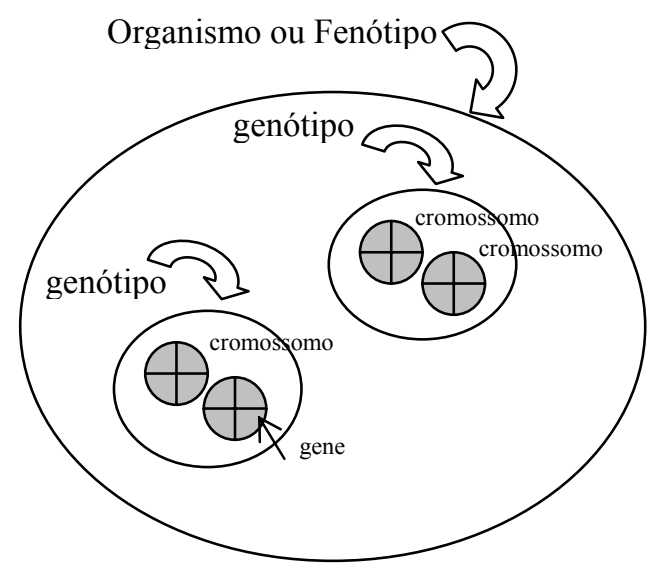

Figura 3.1 - Representação Gráfica do Ambiente de AG's

$\mathrm{Na}$ linguagem análoga à biológica, os AG's iniciam seu processo evolutivo com possíveis soluções, geradas aleatoriamente (população). A população é formada por indivíduos chamados cromossomos, que são as soluções do problema. Um cromossomo ou solução possui um string de bits (binários ou $\in \mathfrak{R}$ ). Cada bit representa uma qualidade (gene) que é uma variável a ser determinada. O string é a representação codificada dos AG's da solução a ser determinada.

A Figura 3.2 mostra o esquema básico de representação de um indivíduo.

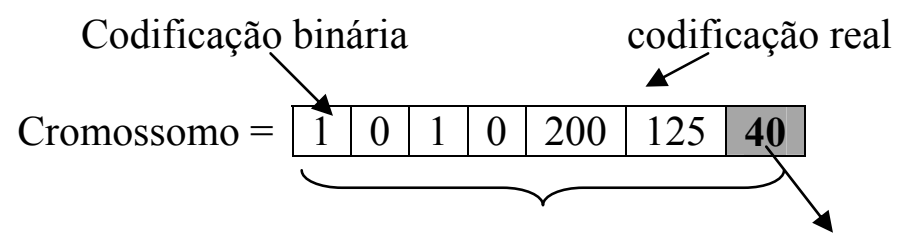

String de genes gene

Figura 3.2 - Representação codificada de um cromossomo ou solução 


\subsection{CODIFICAÇÃO}

Como codificar a solução do problema em um cromossomo é a chave do sucesso dos AG's. No trabalho de Holland (1975), a codificação era feita utilizando strings binários na representação das soluções.

Para muitas aplicações de AG's, especialmente problemas do mundo da engenharia industrial, o AG simples foi difícil de aplicar diretamente porque strings binários não são códigos ou representações naturais.

Durante muito tempo, várias técnicas de codificação que não utilizam strings foram criadas para problemas particulares, por exemplo, codificação de números reais para problemas de otimização restrita e codificação inteira para problemas de otimização combinatória.

Escolher a representação apropriada para as soluções candidatas do problema a ser tratado, é o fundamento para aplicação de AG's para solucionar problemas do mundo real.

Se o problema é escolher as vazões de entrada de um reservatório, a solução em código binário na base 10 fica, por exemplo:

Cromossomo $\mathrm{A}=[011001000,111000010,010000010]$, na representação binária ou, Cromossomo $\mathrm{A}=[200,450,130]$, o mesmo cromossomo decodificado na representação real.

Quando a solução é avaliada através da função objetivo, ela é decodificada, ou seja, transforma-se este string binário em valores numéricos das vazões que abastecem um reservatório, garantindo o atendimento das demandas e o armazenamento no reservatório. Os cromossomos que possuem valores adequados à otimização do problema seguem para o operador seleção. 
Uma das qualidades básicas dos AG's é que trabalham alternativamente no espaço de código (com os strings) e no espaço de soluções (valores numéricos de fato): as operações genéticas (cruzamento e mutação) trabalham no espaço de código (com as soluções na forma codificada de cromossomos) enquanto avaliação da função objetivo e a seleção trabalham no espaço de soluções do problema, conforme Figura 3.3 (GEN; CHENG, 1997):

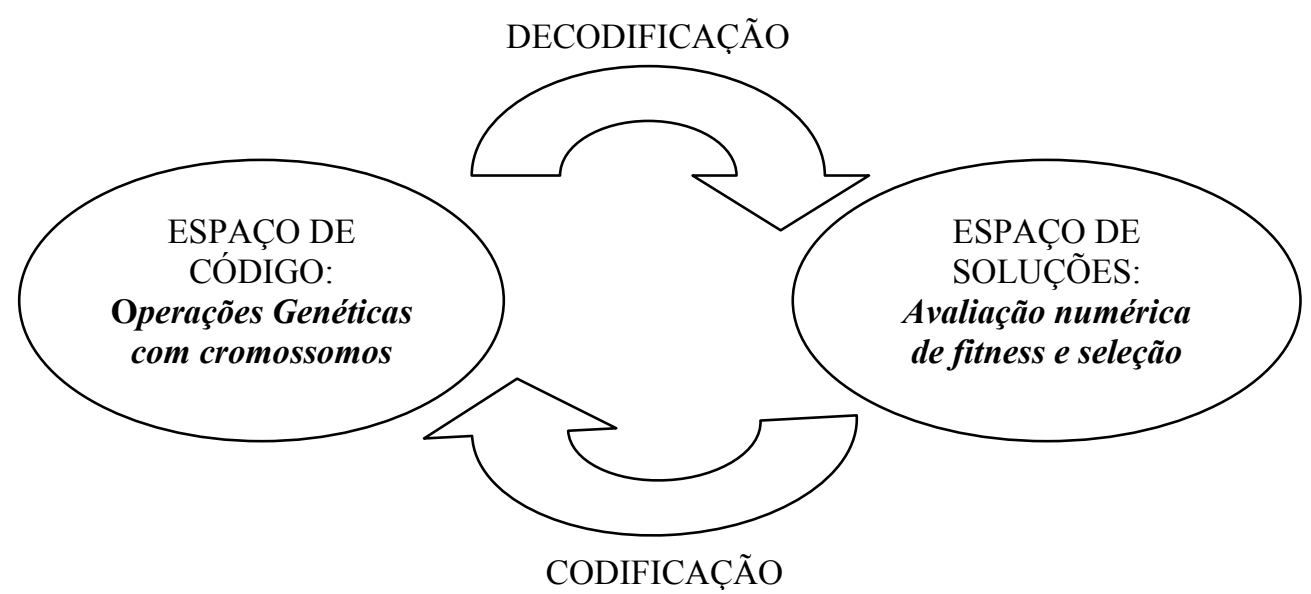

Figura 3.3 - Espaços de Codificação e de Solução

A seleção natural é a ligação entre os cromossomos e o desempenho de suas soluções decodificadas. Para técnicas de decodificação sem strings (non-strings) comentam Gen e Cheng (1997), três questões críticas surgiram, considerando codificação e decodificação entre cromossomos e soluções (ou mapeamento entre fenótipo e genótipo):

(a) Viabilidade de um cromossomo - ocorre quando a solução decodificada de um cromossomo está situada na região viável de um dado problema;

(b) Legalidade - ocorre quando um cromossomo representa uma solução para um dado problema (Figura 3.4): 


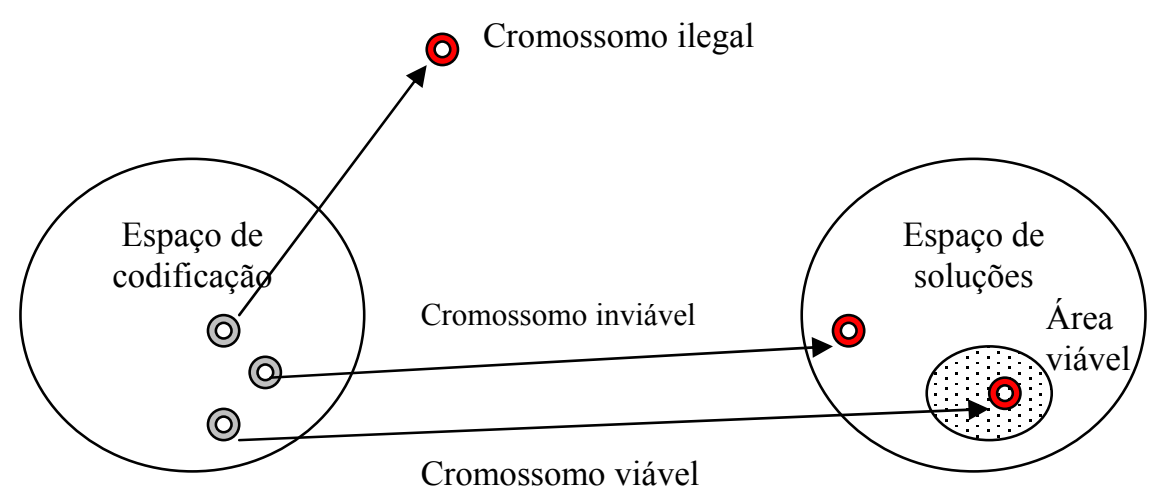

Figura 3.4 - Viabilidade e Legalidade

(c) Mapeamento - correspondência dos cromossomos (soluções codificadas) com as soluções de fato (decodificadas).

Para muitos problemas de otimização, a região viável pode ser representada como sistemas de igualdades ou desigualdades (lineares ou não-lineares). Para tais casos, métodos eficientes de penalidades devem ser propostos para tratar com soluções inviáveis.

Métodos de penalidades podem ser propostos para esses casos de cromossomos inviáveis (dependendo da natureza do problema de otimização restrita). Nesses problemas de otimização restrita, o ótimo ocorre normalmente nos contornos, a penalização na violação da restrição forçará a busca genética a aproximar o ótimo das áreas viáveis e também das inviáveis.

Para muitos problemas de otimização combinatória, códigos específicos de determinados problemas, utilizados em outros de natureza diferente, produzem descendentes ilegais numa operação de cruzamento de um ponto, por exemplo. Como este descendente ilegal não poderá ser decodificado em uma solução, também não poderá ser avaliado e assim, as técnicas de penalidades serão inaplicáveis. Uma forma de resolver este problema é 
introduzir estratégias de reparos combinadas com operadores de cruzamento, que são mais eficientes que as estratégias de rejeição ou de penalidades.

O mapeamento de $m$ cromossomos para $n$ soluções (decodificação) pode pertencer a um dos três casos:

- O mapeamento m:n ou 1:1,

- O mapeamento $m: 1 \mathrm{e}$,

- O mapeamento 1: $n$.

A Figura 3.5 mostra o mapeamento dos cromossomos para soluções do problema (GEN; CHENG, 1997).

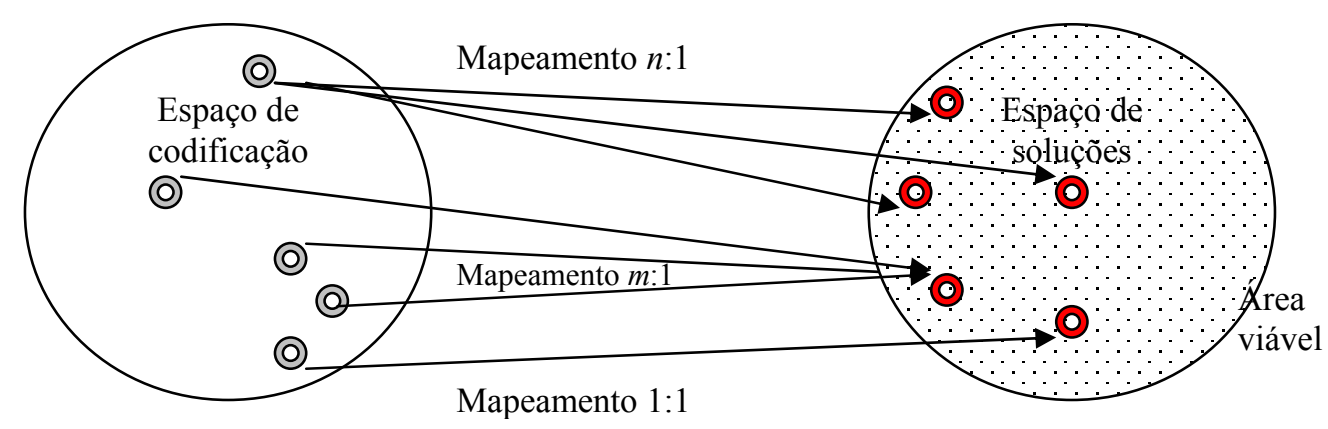

Figura 3.5 - Mapeamento de cromossomos para possíveis soluções

O 1:1 é o melhor entre os casos acima, pois para cada cromossomo codificado existe uma solução viável correspondente no espaço de soluções. No caso de $m$ cromossomos para uma solução viável, existem muitas combinações que podem ser escolhidas, para corresponder a uma solução viável e demanda esforço dos AG's.

O caso 1:n é o mais indesejado, isto é, o problema deve ser considerado cuidadosamente quando se projeta o código para o string não binário para então construir um 
AG eficiente, dadas as muitas possibilidades de um único cromossomo ter muitas soluções no espaço de soluções.

\section{3 - FUNCIONAMENTO DOS AG's}

O funcionamento de um AG básico se desenvolve com os seguintes passos:

a) População inicial: A simulação do processo evolucionário com os AG's usualmente inicia-se com a criação de uma população inicial, gerada a partir de números randômicos, dentro de limites estabelecidos, de acordo com os limites máximos e mínimos das variáveis de decisão do problema. Desta forma, é definida a primeira geração, que representa um conjunto inicial de possíveis soluções do problema.

b) Processo evolucionário propriamente dito: $\mathrm{O}$ processo evolutivo consiste nos seguintes estágios:

$\left.1^{\circ} .^{\circ}\right)$ O algoritmo determina o fitness, isto é, o valor numérico da função objetivo para todas as soluções da população, valor este que habilita a solução como apta ou não, segundo a natureza do problema, de maximização ou minimização;

2. $\left.{ }^{\circ}\right) \mathrm{Na}$ fase seguinte, os indivíduos ou soluções com os quais o processo terá continuidade, são selecionados pelo operador evolutivo seleção. Imitando o processo biológico de "sobrevivência dos mais adaptados", os indivíduos que tiverem um nível de fitness adequado ao problema, têm mais probabilidade de serem escolhidos e copiados para fazer parte da geração seguinte. 
3..$^{\circ}$ Os indivíduos selecionados são recombinados entre si, com regras evolutivas prédefinidas, novas soluções são criadas e submetidas a variações aleatórias de suas “características físicas” ou genes. Os operadores dos AG's que atuam nesta fase são os operadores genéticos cruzamento e mutação. Refere-se ao conjunto de indivíduos obtidos deste processamento, como segunda geração. Prosseguindo seguidamente com esse processo artificial de evolução ao longo das gerações, melhores soluções devem ser obtidas.

c) Fim do processo: Após evoluírem até certo número de gerações, o processo é interrompido segundo critérios de convergência pré-definidos, ou por atingir o número de gerações especificado no início do processo, de maneira a apontar a solução ótima ou cenários de soluções ótimas, obtidas pelo algoritmo.

A Figura 3.6 apresenta o funcionamento de um AG básico de acordo com Gen e Cheng (1997). 


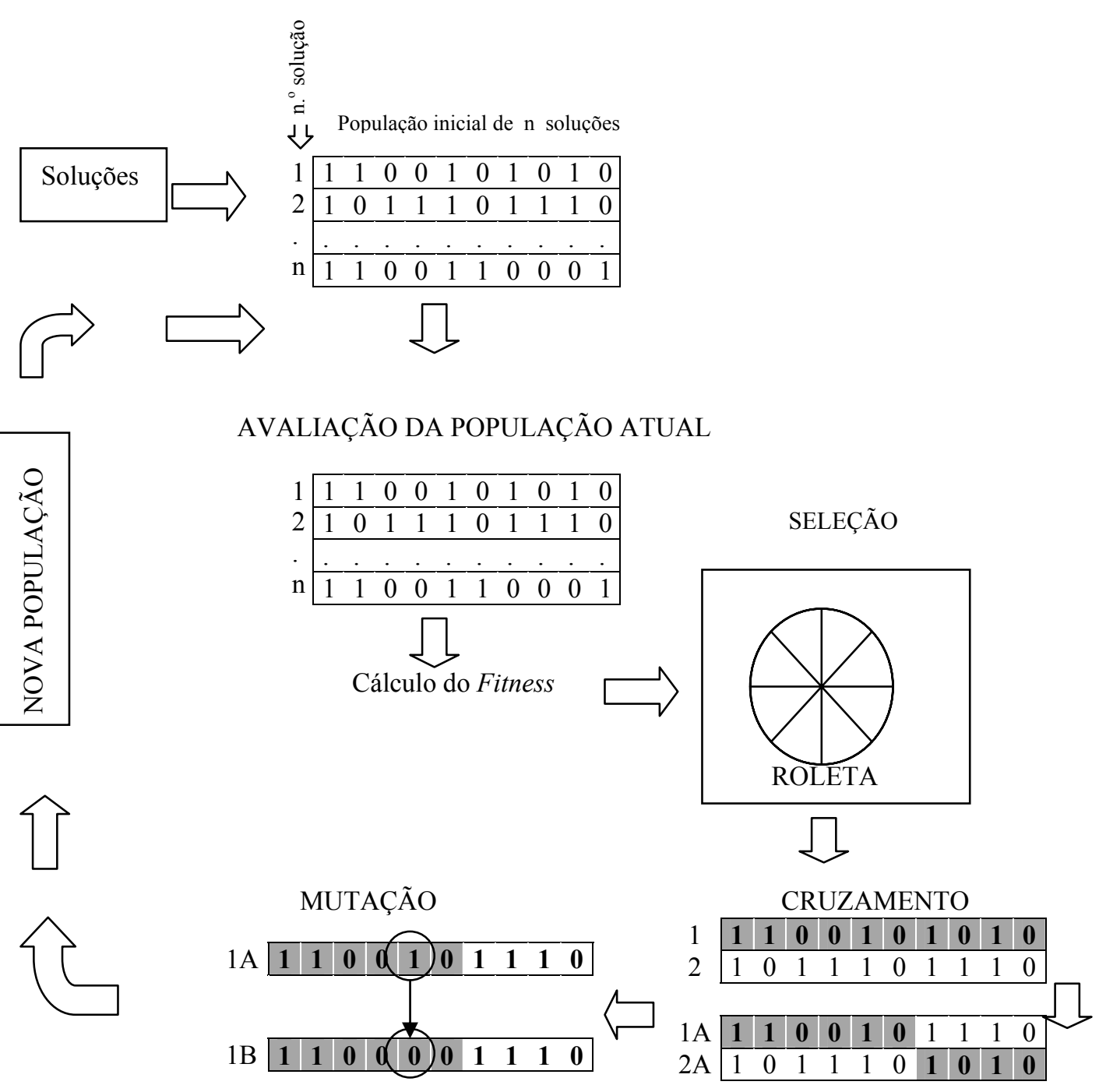

Figura 3.6 - Funcionamento de Algoritmo Genético Básico 


\subsection{DIFERENÇAS DOS AG'S EM RELAÇÃO A OUTRAS TÉCNICAS DE OTIMIZAÇÃO}

Os AG's diferem da otimização convencional principalmente nos seguintes pontos:

- Operam com código do conjunto de soluções e não com as próprias soluções, isto é, são as soluções representadas em um string de variáveis de decisão;

- Buscam a solução ótima a partir de uma população de soluções e não uma simples solução;

- Requerem apenas o cálculo da função objetivo, eliminando problemas freqüentemente encontrados em métodos de natureza mista ou inteira, ou onde derivadas parciais da função objetivo são necessárias;

- Usam regras de transição probabilísticas e não determinísticas, reduzindo a probabilidade de ficarem "presos”em um ótimo local;

- Otimizam parâmetros discretos e contínuos, ou seja, parâmetros com número finito de possíveis valores e parâmetros que podem assumir infinitos valores, respectivamente.

- Fornecem cenários de soluções ótimas e não uma única solução.

Estas propriedades fazem os AG's extremamente adequados a tratar de problemas como otimização da operação em sistemas de abastecimento de água (GOLDBERG; KUO, 1987).

AG's são uma classe de métodos de busca de propósito geral não determinísticos, combinando elementos de busca estocástica e direcionada, podendo explorar (investigar) e explotar (utilizar) o espaço de busca. 
Em outras palavras, conforme o tipo de busca (exploração = verificação; explotação = uso) o cruzamento será determinado pelo ambiente do sistema genético (a diversidade da população de soluções) e não pelo operador em si.

\subsection{MAIORES VANTAGENS DOS AG'S EM RELAÇÃO A OUTRAS TÉCNICAS DE OTIMIZAÇÃO}

Existem grandes vantagens quando se aplicam AG'aos problemas de otimização:

$1^{\circ}$. AG's não necessitam de exigências matemáticas de implementação em relação aos problemas de otimização. Devido à sua natureza evolutiva, irão buscar por soluções sem levar em consideração as características do problema, externas às soluções a serem obtidas;

$2^{\circ}$. AG's podem manipular qualquer tipo de função de aptidão e restrições (linear ou não linear), definidas em espaços de busca de parâmetros discretos, contínuos ou mistos;

$3^{\circ}$. AG's apresentam flexibilidade para hibridização com heurísticas dependentes de domínio para fazer uma implementação eficiente para um problema específico;

$4^{\text {o. }}$ Tratam com grande número de parâmetros a serem determinados, podendo ser aplicados a problemas de grandes dimensões;

$5^{\circ}$. São bem ajustados para processamento paralelo, ou seja, microprocessadores que buscam as soluções ótimas paralelamente e simultaneamente e, 
$6^{\circ}$. Otimizam funções com superfícies extremamente complexas, podendo saltar de um mínimo local (característica de uma meta-heurística) para outra região de soluções viáveis.

\subsection{POPULAÇÃO}

Tipicamente, AG's trabalham com um conjunto de possíveis soluções simultaneamente, diferentemente de técnicas de otimização convencionais. Esse conjunto é chamado população. Cada solução codificada neste conjunto é referida como indivíduo membro da população. Uma geração é a população em certo estágio do processo de otimização.

No início da busca genética, existe uma população aleatória e diversa e, o operador cruzamento tende a executar uma busca ampla para explorar todo espaço de busca. Quando soluções de alto valor de fitness ou aptidão se desenvolvem, o operador cruzamento explora a vizinhança de cada uma delas.

Para Haupt e Haupt (1998), populações de pequenos tamanhos causam aos AG's convergência prematura para um mínimo local porque a pesquisa ocorre em um espaço de parâmetros com poucas possibilidades. Por outro lado, populações grandes gastam muito tempo para achar e agrupar os blocos de construção para solução ótima.

Syswerda $^{5}$ (1991) apud Haupt e Haupt (1998) aconselha a escolha do tamanho da população: o bom senso geral dita que grandes populações trabalharão mais lentamente, mas alcançarão eventualmente melhores soluções que uma de menor tamanho.

\footnotetext{
${ }^{5}$ SYSWERDA, G. Schedule optimization using genetic algorithms in L. Davis, Handbook of Genetic Algorithms, New York: Van Nostrand Reinhold, p-332-349, 1991.
} 
Experiências indicam, entretanto, que esse sentimento não é sempre verdadeiro e que um tamanho de população mais eficiente, é dependente do problema em questão, da representação utilizada e dos operadores que manipulam a codificação.

Uma alternativa é gerar aleatoriamente a primeira metade da população e a segunda metade, seria o restante da população, sem qualquer modificação. Essa técnica garante a diversidade por requerer que todos os bits assumam tanto o valor zero quanto valor igual a 1 (um), dentro da população.

Uma vez que a superfície de custo é adequadamente amostrada (exploração), o algoritmo trabalha com subconjuntos das melhoras amostras (explotação).

Os operadores genéticos cruzamento e mutação aumentam a variação de amostragem do algoritmo.

\subsection{FITNESS}

Os cromossomos evoluem através de sucessivas iterações, chamadas gerações, como mencionado anteriormente. Durante cada geração, os cromossomos são avaliados, usando algumas medidas de aptidão, qualidades ou fitness, isto é, a função de fitness calcula a aptidão de um indivíduo com respeito às qualidades deste indivíduo.

O fitness pode ser a expressão do valor da função objetivo (ou função de aptidão) do cromossomo, como solução candidata de acordo com o problema, representada por ele. É também função das restrições do problema e pode ser modificada através da introdução de penalidades quando as restrições não são satisfeitas. 
Assim, esta função pode considerar, segundo Savic et al. (1997), um simples objetivo, meta ou restrição, ou ainda agregar diversos critérios, observando mais qualidades a serem determinadas.

O fitness é um valor numérico singular que é usado no processo de seleção, para auxiliar na probabilidade de um indivíduo ser representado na próxima geração.

Para problemas de maximização o fitness é geralmente, o valor da função objetivo ou de aptidão $f(x)$, de acordo com Gen e Cheng (1997). Em problemas de minimização, por exemplo, pode-se estimar, inicialmente, um valor grande para o fitness mínimo, de forma que os valores otimizados de fitness, sejam sempre reduzidos ao longo das gerações. O cálculo do fitness para cada indivíduo da população pode ser descrito pela equação 3.1:

$$
\operatorname{fitness}\left(x^{k}\right)=f\left(x^{k}\right)
$$

onde $\mathrm{k}=1,2, \ldots .$, população total

A avaliação da função de aptidão dita a regra para o ambiente dos AG's em termos do seu fitness. Para calcular o fitness total para toda a população, pode-se utilizar a equação 3.2:

$$
\text { FitnessPopulação }=\sum_{k=1}^{\text {popsize }} \text { fitness }\left(x^{k}\right)
$$




\subsection{OPERADORES DOS AG's}

Os AG's utilizam no processo de otimização o operador evolutivo seleção e os operadores genéticos cruzamento e mutação, para gerar os novos indivíduos a cada nova geração, descritos mais detalhadamente a seguir.

\subsubsection{Seleção}

As operações genéticas são feitas pelos operadores cruzamento e mutação enquanto que as operações evolutivas são feitas pelo operador seleção. Segundo a Evolução Darwiniana, as operações genéticas imitam o processo hereditário dos genes para criar novos descendentes. Essa descrição difere do paradigma ditado por Holland (1975), onde a seleção é feita para obter os "pais” por recombinação.

A seleção fornece a força de direção de busca em um AG e nesta direção, a pressão de seleção é crítica. Em um extremo de pressão de seleção alta, a busca terminará prematuramente enquanto no outro extremo, com baixa pressão, o progresso será mais lento do que o necessário. Pressão de seleção então, é a forma mais seletiva com que os AG's buscam as melhores soluções ao longo do espaço de busca.

Tipicamente, aplicar baixa pressão de seleção é indicado no início da busca do AG, em favor de uma ampla exploração do espaço de busca, enquanto a alta pressão é recomendada no final, de forma a explotar (utilizar) as regiões mais promissoras do espaço de busca. 
A seleção direciona a busca de AG's através das regiões promissoras no espaço de busca. Muitos métodos de seleção têm sido propostos, examinados e comparados. Existem três assuntos básicos envolvidos na fase de seleção:

- Espaço de amostragem;

- Mecanismos de amostragem e,

- Probabilidade de seleção.

\subsubsection{Espaço de amostragem}

O procedimento de seleção pode criar uma nova população para a próxima geração, baseada tanto em todos os pais, todos os descendentes da população corrente, ou como parte deles. Isso leva ao problema de espaço de amostragem.

O espaço de amostragem, seu mecanismo e a probabilidade de seleção influem na pressão seletiva e no comportamento do AG. Tal espaço é caracterizado por dois fatores: tamanho e componentes (pais ou descendentes).

Tomemos as variáveis DimPop como o tamanho da população e DimFillhos a quantidade de filhos produzida em cada geração.

O espaço regular de amostragem tem o tamanho de DimPop e contém todos os descendentes, mas apenas partes dos pais.

Para evitar que cromossomos aptos se percam na substituição de pais por filhos, Holland (1975) sugeriu que quando cada filho "nasçer", ele substitua um cromossomo escolhido aleatoriamente, da população corrente, como mostrado na Figura 3.7: 


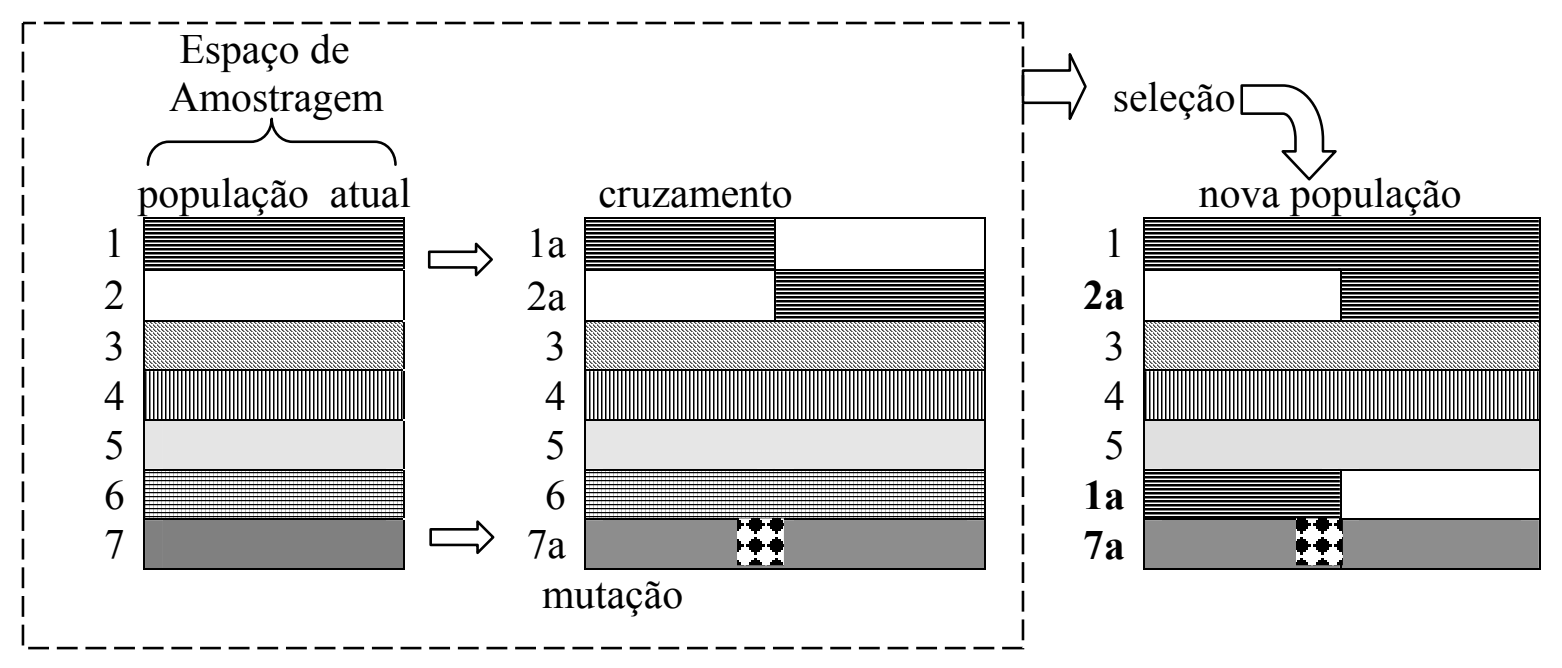

Figura 3.7 - Seleção em um espaço regular de amostragem após cruzamento e mutação

Na Figura 3.7, o espaço de amostragem é representado pela população, em barras diferentes. Os descendentes que são produzidos pelos operadores de cruzamento (1a e 2a) e mutação (7a), substituem somente os cromossomos 2, 6 e 7, que não seguem no processo evolutivo, ilustrando a afirmação de Holland (1975).

Espaços aumentados de amostragem possuem o tamanho de toda população DimPop + DimFillhos e contém pedaços dos pais e descendentes. Quando a seleção é feita em um espaço de amostragem aumentado, tanto pais como descendentes tem chance de competir para sobreviver.

A Figura 3.8 ilustra a seleção baseada no espaço aumentado de amostragem (GEN; CHENG, 1997): 


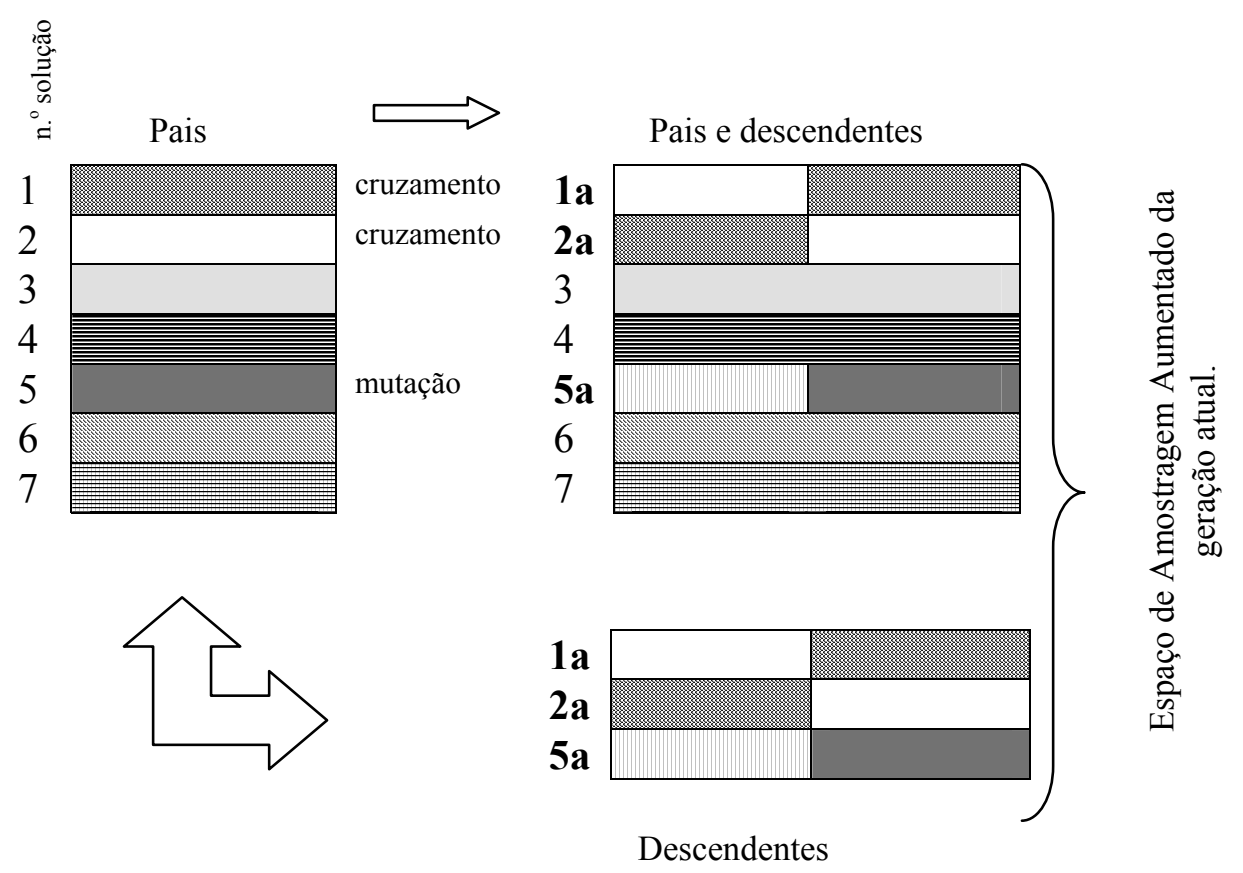

Figura 3.8 - Espaço aumentado de amostragem

Na Figura 3.8 em análise, alguns pais da geração anterior (3, 4, 6 e 7), foram mantidos na população e portanto, no espaço de amostragem, e alguns descendentes (1a, 2a e 5a) foram selecionados para também constituir o espaço de amostragem aumentado, da geração atual.

Estes pais, no exemplo da Figura 3.8, sofrem ação dos operadores cruzamento e mutação, gerando novos descendentes que irão constituir a população da nova geração. Com igual probabilidade de serem escolhidos, alguns pais e alguns descendentes da geração anterior foram mantidos, e outros substituídos pelos novos descendentes.

Embora muitos dos métodos de seleção sejam baseados no espaço regular de amostragem, é fácil implementá-los no espaço de amostragem aumentado. 
Não há necessidade de cautela se, comentam Gen e Cheng (1997), na introdução de altas taxas de mutação e cruzamento, ocorre muita perturbação aleatória caso esteja sendo usada seleção num espaço de amostragem aumentado (pais e filhos).

Uma vantagem evidente dessa técnica é que pode-se melhorar o desempenho do AG com as taxas mais elevadas de cruzamento e mutação.

\subsubsection{Mecanismos de amostragem}

Mecanismos de amostragem preocupam-se com o problema de como selecionar cromossomos do espaço de amostragem. Três técnicas básicas têm sido usadas para amostragem dos cromossomos:
(a) Estocástica;
(b) Determinística e,
(c) Mista.

(a) Estocástica - a seleção determina o número atual de cópias que cada cromossomo recebe, com base na sua probabilidade de sobrevivência. É dividido em duas partes:

- Determinação do valor esperado proporcional do cromossomo: O valor esperado do cromossomo é um número real, que indica o número médio de descendentes que o cromossomo deveria receber. 
- Adoção do valor esperado no número de descendentes: Para adotar o valor esperado proporcional de cópias $\left(e_{k}\right)$ para o cromossomo $k$ no número de descendentes, cada cromossomo recebe um número de cópias, conforme o valor de $e_{k}$, de forma que a população permaneça com tamanho constante.

Para o cromossomo $k$ com fitness $f_{k}$, calcula-se primeiramente a probabilidade se seleção $p_{k}$ :

$$
p_{k}=\frac{f_{k}}{\sum_{j=1}^{p o p s i z e} f_{j}}
$$

onde popsize é o tamanho da população. Calcula-se então, o número esperado de cópias dado pela equação:

$$
e_{k}=\text { popsize } * p_{k}
$$

O melhor método conhecido dessa classe é a ROLETA. A idéia básica é a partir da determinação da probabilidade de seleção para cada cromossomo, proporcional ao seu valor de fitness, girar a roleta popsize vezes. O processo de seleção ocorre em cada giro da roleta, selecionando-se um único cromossomo para a nova população. A seleção tipo roleta é baseada em estatística. Para pequenas populações essa estatística nem sempre se manifesta. Mesmo membros mais adaptados da população podem não ser selecionados e não emergirem por centenas de gerações. Esse problema prolonga a otimização. 
(b) Determinística - seleciona os melhores cromossomos, considerando o tamanho total do espaço de amostragem, de forma que estes melhores constituam a população inteira. Pertencem a esse método seleção tipo $(\mu+\lambda)$ e tipo $(\mu, \lambda)$. Na seleção $(\mu+\lambda)$ os $\mu$ pais tem iguais chances de competição dos $\lambda$ filhos. A seleção tipo $(\mu, \lambda)$ os $\mu$ melhores descendentes serão pais na próxima geração. Assim também é a seleção truncada e de blocos, que estabelecem escalas para todos os cromossomos, de acordo com seu fitness, e selecionam os melhores como pais. A seleção elitista garante que os melhores cromossomo sejam presentes em todas as gerações, intocados, garantindo que sobreviverão até serem substituídos por outros membros melhores, para nova geração, se não for selecionado através de qualquer outro processo de seleção.

(c) Mista - contém qualidades estocásticas e determinísticas simultaneamente. O exemplo típico é a seleção por torneio de Goldberg (1987). Esse método escolhe aleatoriamente um conjunto de cromossomos, e retira o melhor cromossomo do conjunto para reprodução. O número de cromossomos no conjunto é chamado tamanho do torneio, e o tamanho comum é igual a 2 (dois), o torneio binário. $\mathrm{Na}$ seleção por torneio estocástica, as probabilidades são calculadas normalmente e pares sucessivos de cromossomos são formados usando a roleta. Após formar um par, o cromossomo com maior fitness é escolhido e inserido na nova população. O processo continua a até a população se completar. 
3.8.1.3. Probabilidade de seleção

Como determinar a probabilidade de seleção para cada cromossomo? Num procedimento proporcional de seleção, a probabilidade de seleção (também chamada de probabilidade de sobrevivência), é proporcional ao fitness de cada cromossomo.

Mecanismos de escala e ranking são propostos para mitigar problemas de "supercromossomos" dominantes nas gerações iniciais e de comportamento aleatório de busca nas últimas gerações.

Métodos de escala evidenciam valores brutos da função de aptidão para alguns valores reais positivos e a probabilidade de sobrevivência para cada cromossomo é determinada de acordo com esses valores.

Métodos de ranking ignoram os valores reais da função de aptidão e usam um ranking de cromossomos em vez de determinar a probabilidade de sobrevivência. Em geral, o scaling fitness $\left(f^{\prime}{ }_{k}\right)$ do fitness bruto $\left(f_{k}\right)$ para um cromossomo $k$ é:

$$
f^{\prime}(k)=g\left(f_{k}\right)
$$

onde $\mathrm{g}($ ) transforma fitness bruto em scaling fitness. A função $\mathrm{g}(\mathrm{)}$ ) pode ter diferentes formas para produzir diferentes métodos de escala como truncamento sigma, escala linear, escala de leis de potência, logarítmicas, etc.

\subsubsection{Cruzamento}

A recombinação ou cruzamento é o mecanismo de criação de indivíduos filhos (novas soluções), através da recombinação de indivíduos pais (soluções atuais). É o operador 
que torna os AG's diferentes dos outros algoritmos evolucionários. Geralmente é realizada através da simples permuta ou da combinação de características correspondentes entre soluções pais, sendo que o primeiro esquema mostra-se adequado ao caso de soluções representadas através de código binário, enquanto que o segundo é mais utilizado quando o alfabeto de representação de soluções é real.

Gen e Cheng (1997) explicam que a reprodução é um processo através do qual, séries de indivíduos são copiadas de acordo com seus valores dentro da função de aptidão. Copiar strings de acordo com seus valores de fitness significa que strings com melhores valores, têm maior probabilidade de contribuição ou de terem mais descendentes na próxima geração. $\mathrm{O}$ cruzamento, é claro, é uma versão artificial da seleção natural de Darwin, segundo a qual só sobrevivem as criaturas mais adaptadas.

$\mathrm{O}$ cruzamento ocorre se um número aleatório $r$ uniformemente distribuído entre 0 e 1, for menor que a probabilidade de cruzamento, definida previamente. Michalewicz (1992) descreve três tipos de cruzamento mais usuais: de um ponto, de dois pontos e uniforme.

\subsubsection{Cruzamento de um ponto}

Este tipo de cruzamento escolhe aleatoriamente uma posição no string para combinação de informações a partir deste ponto. O resultado obtido pela extração e troca dos sub-strings criados com os strings pais corresponde a dois novos cromossomos, os quais preservam muitas informações genéticas de seus pais.

O exemplo apresentado por Savic et al. (1997) a seguir mostra este princípio usando um string de 12 bits e um corte pontual após a posição 8 (oito) neste string (os pontos de corte nos strings estão marcados com linhas duplas). 
Os dois sub-strings dos strings pais mostrados em cinza, são re-alocados, formando parte do primeiro descendente e parte do segundo. Os outros dois sub-strings, mostrados em branco, formam o segundo descendente deste exemplo, conforme Figura 3.9:

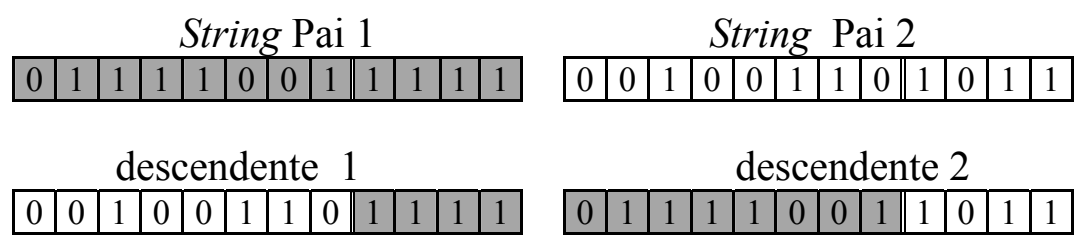

Figura 3.9 - Esquema ilustrativo de cruzamento de um ponto

\subsubsection{Cruzamento de dois pontos}

O cruzamento de dois pontos pode ser considerado como uma forma mais geral do cruzamento de um ponto.

Para ilustrar esta afirmação, Savic et al. (1997) vêem um cromossomo como um loop formado pela união do início e do fim de um cromossomo.

Para executar este cruzamento, dois pontos de corte são escolhidos aleatoriamente considerando que para um ponto de cruzamento somente um ponto foi escolhido, e a partida do string pode ser interpretado como um ponto fixo de corte. Da mesma forma que no cruzamento de um ponto, aqui o cruzamento de dois pontos extrai um simples segmento do string.

O exemplo apresentado a seguir por Savic et al. (1997) mostra este princípio dos AG's, usando um string de 12 bits novamente, como no exemplo para o cruzamento de 1 (um) ponto. 
Os dois pontos de corte (mostrados como linhas duplas) são escolhidos após as posições 3 (três) e 8 (oito) em ambos strings.

Assim, dois novos sub-strings são criados novamente, mas agora o descendente 1 (um) possui o sub-string intermediário do String Pai 2. Os sub-strings restantes do Pai 2 são locados juntos, formando o descendente 2 (dois) e os sub-strings inicial e final formam descendente 1(um), de acordo com a Figura 3.10:

String Pai 1

String Pai 2

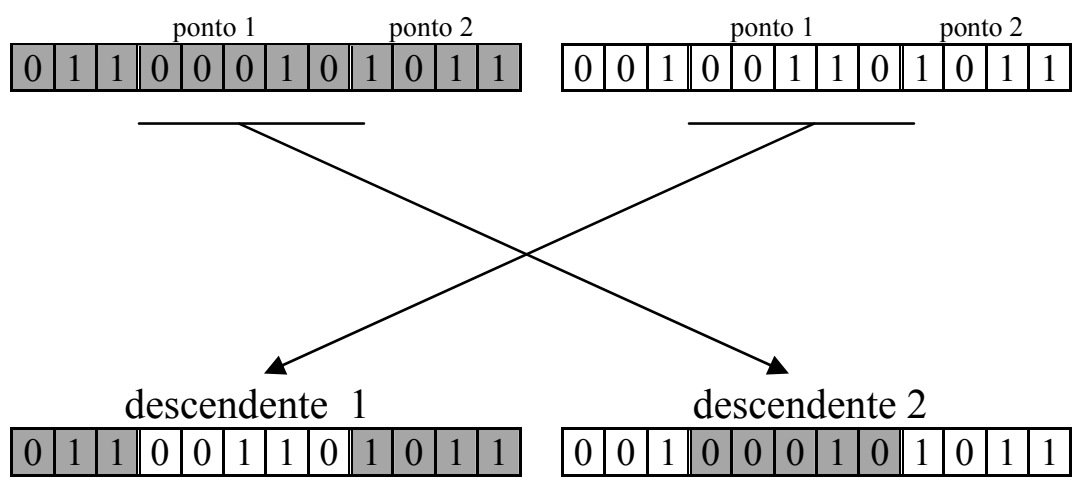

Figura 3.10 - Esquema ilustrativo de cruzamento de dois pontos

O desempenho dos AG's depende do desempenho do operador cruzamento utilizado. A taxa de cruzamento dada por $p_{c}$, é a taxa entre o número de descendentes produzidos $\left(\mathrm{x}_{\mathrm{k}}{ }_{\mathrm{k}}\right)$ em cada geração, multiplicados pelo tamanho da população.

$$
p_{c}=x_{k}^{\prime} * \text { popsize }
$$


Essa taxa controla o número esperado de cromossomos que cruzam. Uma taxa alta permite exploração de mais de um espaço de soluções pela introdução de novos cromossomos na população e reduz as chances de cair num falso ótimo.

Em contrapartida, uma taxa muito alta eleva o tempo de processamento explorando regiões não promissoras de soluções e dessa forma, bons blocos de construção não terão oportunidade de se unirem em um único cromossomo. Uma taxa baixa por outro lado, não explora muito a superfície de custo.

\subsubsection{Cruzamento uniforme}

O cruzamento uniforme prevê que genes individuais sejam considerados na troca de informações para criação de novos indivíduos, ao invés de blocos de genes ou material genético. No exemplo de Deb (2001) a idéia pode ser melhor visualizada:

Pais

Descendentes

\begin{tabular}{|l|l|l|l|l|l|l|l|l|l|}
\hline $\mathbf{0}$ & $\mathbf{1}$ & $\mathbf{0}$ & $\mathbf{0}$ & $\mathbf{0}$ & $\mathbf{0}$ & $\mathbf{1}$ & $\mathbf{0}$ & $\mathbf{1}$ & $\mathbf{0}$ \\
\hline 0 & 1 & 1 & 1 & 0 & 0 & 0 & 1 & 1 & 0 \\
\hline
\end{tabular}$\rightarrow$\begin{tabular}{|l|l|l|l|l|l|l|l|l|l|}
\hline $\mathbf{0}$ & 1 & $\mathbf{0}$ & 1 & 0 & $\mathbf{0}$ & 0 & $\mathbf{0}$ & 1 & $\mathbf{0}$ \\
\hline 0 & $\mathbf{1}$ & 1 & $\mathbf{0}$ & $\mathbf{0}$ & 0 & $\mathbf{1}$ & 1 & $\mathbf{1}$ & 0 \\
\hline
\end{tabular}

Foram trocados o $2 .^{\circ}, 4 .^{\circ}, 5 .^{\circ}, 7 .^{\circ}$ e $9 .^{\circ}$ bits entre os pais, gerando descendentes diferentes.

\subsubsection{Mutação}

A mutação é a sistemática que possibilita a introdução de características genéticas novas às soluções existentes, através da eventual substituição de genes dos indivíduos. 
Geralmente é realizada bit por bit (no caso de código binário) ou gene por gene (código real), possibilitando que cada bit ou gene seja alterado com uma pequena probabilidade ou taxa $p_{m}$ entre 0.001 e 0.1 , geralmente constante, ou variáveis de acordo com técnicas avançadas de ajuste dinâmico (REIS; AKUSTU, 2002).

A mutação tem papel importante na:

(a) Substituição de genes perdidos da população durante o processo de seleção, tal que possam ser testados em um novo contexto ou,

(b) Prover genes que não existiam na população inicial.

Para Gen e Cheng (1997), a taxa de mutação $p_{m}$ é definida como percentual (\%) no número total de genes da população. Essa taxa controla a variação pela qual são introduzidos novos genes na população, para serem testados. A probabilidade de mutação pode ser definida como:

$$
p_{\text {mut }}=\frac{1}{C_{\text {lenght }}}
$$

onde $\mathrm{C}_{\text {lenght }}$ é o comprimento total do cromossomo em genes.

Se for muito baixa, muitos genes úteis não serão testados e se muito alta, haverá grande perturbação aleatória. Descendentes iniciarão perdendo material genético dos pais e o algoritmo perderá habilidade de aprendizado a partir do histórico da busca.

Para Goldberg (1987) a taxa de mutação deve ser inversamente proporcional ao tamanho da população.

Diversas são as possibilidades de mutação, comentam Reis e Akutsu (2002), podendo ser uniforme ou modificada. Novamente o exemplo de 12 bits apresentado anteriormente por Savic et. al. (1997) da Figura 3.11 será usado para ilustrar a mutação uniforme. Neste exemplo a posição 8 (oito) no cromossomo é mutada. 
Cromossomo antes da mutação \begin{tabular}{|l|l|l|l|l|l|l|l|l|l|l|l|}
\hline 1 & 0 & 0 & 0 & 1 & 1 & 1 & 1 & 1 & 0 & 1 & 1 \\
\hline
\end{tabular}

Cromossomo após a mutação

\begin{tabular}{|l|l|l|l|l|l|l|l|l|l|l|l|}
\hline 1 & 0 & 0 & 0 & 1 & 1 & 1 & $\mathbf{0}$ & 1 & 0 & 1 & 1 \\
\hline
\end{tabular}

Figura 3.11 - Esquema ilustrativo de mutação uniforme

A mutação uniforme modificada, segundo Wardlaw e Sharif (1999), permite a modificação de um gene de uma quantia positiva ou negativa especificada. Tais autores empregaram a referida sistemática, mas não especificam claramente o procedimento adotado.

\subsubsection{Convergência de AG's binários}

Não existe prova matemática de convergência ou qualquer garantia de que AG's identifiquem o ótimo global. Existe uma prova de convergência para AG's binários, chamada Teorema do Esquema (HOLLAND, 1975).

Um esquema é um string de caracteres consistindo em dígitos binários 1 (um) e 0 (zero) e um caracter adicional "não importa", \#. Assim um esquema $11 \# \# 00$ significa que os dois dígitos centrais podem ser tanto 0 (zero) como 1 (um).

O Teorema do Esquema diz:

"Esquemas com melhores custos do que a média ocorrem exponencialmente com mais freqüência na próxima geração. Esquemas com custos piores do que a média ocorrem menos freqüentemente na próxima geração”. 
A idéia é que esquemas (strings) de melhor fitness sobrevivam nas futuras gerações. Em muitos AG's utiliza-se a estatística populacional na forma de média da população, desvio padrão e custo mínimo. Qualquer dessas funções ou combinação entre elas pode servir como teste de convergência.

Após a aplicação dos operadores de recombinação e mutação, a nova população está pronta para a próxima avaliação, e o ciclo se repete até que a condição de finalização seja considerada satisfeita. O critério de finalização mais simples é realizar um determinado número de iterações, comentam Reis e Akutsu (2002). Entretanto não se conhece a priori o número de gerações mais apropriado a determinado tipo de problema. Podem ser usados critérios alternativos de convergência baseados no fato de que ou a maioria dos cromossomos é idêntica ou nenhuma melhora significativa no valor da função de aptidão ocorreu para um determinado número de gerações.

\subsection{VARIAÇÕES DOS AG's}

\subsubsection{Codificação de parâmetros contínuos}

Em muitas aplicações de AG's para problemas de otimização restrita, a técnica de codificação real, contínua ou de ponto flutuante, é usada para representar soluções para dado problema. O AG de parâmetros contínuos também é chamado de AG de valor real.

De acordo com Haupt e Haupt (1998), em tais problemas cada parâmetro requer muitos bits para representá-lo totalmente. Se o número de parâmetros é grande, o tamanho do cromossomo cresce rapidamente. Poderia-se, em princípio, usar qualquer representação concebível para codificar parâmetros. Quando esses parâmetros são naturalmente 
quantificados, o AG binário ajusta-se bem. Entretanto, quando os parâmetros são contínuos é mais lógico representá-los por números de ponto flutuante (floating-point).

$\mathrm{Na}$ implementação da codificação real, cada cromossomo é codificado como vetor $\in \Re$ de mesmo comprimento do vetor solução. Os genes dos indivíduos são inicialmente valores alocados dentro dos limites viáveis da variável representada.

Assim, ainda que os AG's binários tenham sua precisão limitada pela representação binária dos parâmetros, o uso de números reais facilmente permite representação pela precisão de máquina da lógica computacional.

Embora parâmetros possam assumir qualquer valor, na realidade um computador digital representa números por um número finito de bits. Quando referimos ao AG de parâmetros contínuos, significa que o computador usa sua precisão interna para definir a precisão do parâmetro contínuo.

Esse AG de parâmetros contínuos tem como vantagens:

- Dispensa codificação;

- Requerer menos armazenamento que o $\mathrm{AG}$ binário porque um único número de ponto flutuante representa o parâmetro em vez de inteiros de $n$ bits;

- Representação de maior precisão dos parâmetros contínuos e assim, conseqüentemente, melhores resultados em termos de velocidade de convergência;

- Não necessitar de nenhuma discretização no espaço das variáveis de decisão. 
Nos últimos anos, diversos operadores genéticos foram propostos para tais codificações, sendo eles os operadores convencionais, operadores aritméticos e operadores baseados na direção, descritos a seguir.

\subsubsection{Operadores convencionais para AG's de parâmetros contínuos}

\subsubsection{Cruzamento}

Esse tipo de operador de cruzamento é análogo ao da implementação binária, afirmam Gen e Cheng (1997). O operador básico de cruzamento é o de um ponto. Tomemos dois pais sendo $\mathrm{x}=\left[\mathrm{x}_{1}, \mathrm{x}_{2}, \ldots, \mathrm{x}_{\mathrm{n}}\right]$ e $\mathrm{y}=\left[\mathrm{y}_{1}, \mathrm{y}_{2}, \ldots ., \mathrm{y}_{\mathrm{n}}\right]$. Se eles forem cruzados após a $k$-ésima posição, os descendentes resultantes serão:

Os Pais antes do cruzamento:

$$
\begin{aligned}
& \mathrm{x}=\left[\mathrm{x}_{1}, \mathrm{x}_{2}, \ldots, \mathrm{x}_{\mathrm{k}}, \mathrm{x}_{\mathrm{k}+1}, \mathrm{x}_{\mathrm{k}+2}, \ldots ., \mathrm{x}_{\mathrm{n}}\right] \\
& \mathrm{y}=\left[\mathrm{y}_{1}, \mathrm{y}_{2}, \ldots ., \mathrm{y}_{\mathrm{k}}, y_{k+1}, y_{k+2}, \ldots ., \mathrm{y}_{\mathrm{n}}\right]
\end{aligned}
$$

Os descendentes:

$$
\begin{aligned}
& \mathrm{x}^{\prime}=\left[\mathrm{x}_{1}, \mathrm{x}_{2}, \ldots ., \mathrm{x}_{\mathrm{k}}, y_{k+1}, y_{k+2}, \ldots ., \mathrm{y}_{\mathrm{n}}\right] \\
& \mathrm{y}^{\prime}=\left[\mathrm{y}_{1}, \mathrm{y}_{2}, \ldots ., \mathrm{y}_{\mathrm{k}}, \mathbf{x}_{\mathrm{k}+\mathbf{1}}, \mathrm{x}_{\mathbf{k}+2}, \ldots . ., \mathrm{x}_{\mathrm{n}}\right]
\end{aligned}
$$

Os cruzamentos de um ponto, de dois pontos e cruzamento uniforme dos parâmetros binários, também valem para os parâmetros contínuos. 


\subsubsection{Mutação}

Aqui, os operadores de mutação são pouco diferentes dos tradicionais, comentam Gen e Cheng (1997). Um gene, sendo um número real, é modificado dentro de um intervalo específico. O operador básico é a mutação uniforme.

A mutação uniforme é realizada de forma que cada elemento ou gene de um cromossomo possui exatamente a mesma chance de sofrer mutação. Em um patamar mais avançado, a mutação não uniforme é utilizada pelo refinamento das soluções, através de multiplicadores controlados, aplicados aos valores das variáveis de decisão, de acordo com a geração.

Na mutação uniforme, um gene sendo um número real, é simplesmente substituído por um número real selecionado aleatoriamente, dentro de um intervalo de valores especificado que estes números reais possam variar.

Tomando-se um cromossomo a ser mutado $\mathrm{x}=\left[\mathrm{x}_{1}, \mathrm{x}_{2}, \ldots, \mathrm{x}_{\mathrm{n}}\right]$, primeiramente seleciona-se um número aleatório $k \in\left[\begin{array}{ll}1, & \mathrm{n}\end{array}\right]$ e então produz-se um descendente $\mathrm{x}^{\prime}=\left[\mathrm{x}_{1}, \ldots, \mathbf{x}_{\mathbf{k}}, \ldots, \mathrm{x}_{\mathrm{n}}\right]$, onde $\mathrm{x}_{\mathrm{k}}{ }_{\mathrm{k}}$ é um valor aleatório (com distribuição uniforme de probabilidade) dentro do intervalo $\left[x_{k}^{l}, x_{k}^{u}\right]$.

Os valores $x_{k}^{l}$ e $x_{k}^{u}$ são tipicamente os limites inferior (lower) e superior (upper) da variável $\mathrm{x}_{\mathrm{k}}$, os quais podem ser determinados pela restrição de domínio desta variável. O intervalo também pode ser calculado por um conjunto de restrições (desigualdades).

O gene $x_{k}^{\prime}$ pode ser substituído inclusive ou por $x_{k}^{l}$ ou por $x_{k}^{u}$, cada um com igual probabilidade. Esse tipo de variação é chamada mutação de contorno. Em vez dos limites inferior ou superior, esse intervalo pode ser também formado como $\left[\mathrm{x}_{\mathrm{k}-1}, \mathrm{x}_{\mathrm{k}+1}\right]$, ou seja, entre os genes imediatamente anterior e posterior. Essa variação é a mutação plana. 


\subsubsection{Operadores aritméticos para parâmetros contínuos}

\subsubsection{Cruzamento Aritmético}

Os operadores aritméticos são construídos seguindo o conceito de combinação linear de vetores da área da Teoria dos Conjuntos Convexos.

Geralmente, a média ponderada de dois vetores $x_{1}$ e $x_{2}$ é calculada como:

$$
\lambda_{1} x_{1}+\lambda_{2} x_{2}
$$

Se os multiplicadores são restritos a:

$$
\lambda_{1}+\lambda_{2}=1
$$

onde $\lambda_{1}>0$ e $\lambda_{2}>0$, a forma ponderada da equação 3.8 é conhecida como combinação convexa.

Se a condição de não-negatividade dos multiplicadores cai, a combinação é conhecida como combinação relacionada (affine ou do latim affinis = ligada a, afim). Finalmente se os multiplicadores simplesmente são requeridos pertencer ao espaço $E^{l}$, então a combinação é dita linear.

Similarmente, operadores de cruzamento aritméticos são definidos como combinação de dois vetores (cromossomos $x_{1}$ e $x_{2}$ ):

$$
\begin{aligned}
& x_{1}^{\prime}=\lambda_{1} x_{1}+\lambda_{2} x_{2} \\
& x_{2}^{\prime}=\lambda_{1} x_{2}+\lambda_{2} x_{1}
\end{aligned}
$$

De acordo com a restrição nos multiplicadores se produzem três tipos de cruzamento: convexo, relacionada (affine) e linear. A Figura 3.9 ilustra a localização dos descendentes em 
um espaço bidimensional, com a utilização dos cruzamentos aritméticos convexo, relacionado (affine) e linear.

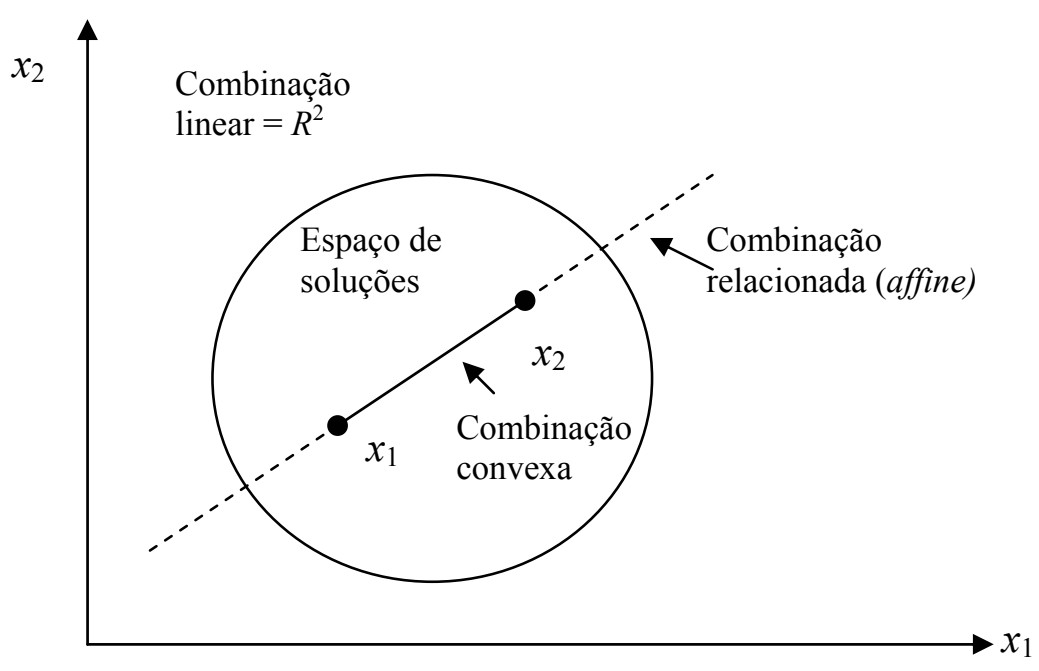

Figura 3.12 - Ilustração da localização dos descendentes gerados pelas combinações linear, relacionada (affine) e convexa, em um espaço bidimensional.

Os descendentes gerados com a combinação convexa ficam sobre a linha sólida, os descendentes gerados pela combinação affine ficam tanto sobre a linha tracejada quanto sobre a linha sólida e os descendentes gerados pela combinação linear estão sobre todo o plano bidimensional.

O cruzamento convexo é o mais comumente utilizado. Quando se restringe que $\lambda 1=\lambda 2=0.5$, produz-se um caso especial, normalmente chamado de cruzamento médio ou intermediário.

No cruzamento tipo affine, os multiplicadores podem ser $\lambda_{1}=1.5$ e $\lambda_{2}=-0.5 \mathrm{ou}$ como números reais aleatórios no intervalo $[-\mathrm{d}, 1+\mathrm{d}]$.

No cruzamento linear os multiplicadores ficam restritos a seguinte forma: 


$$
\lambda_{1}+\lambda_{2} \leq 2
$$

para $\lambda_{1}>0$ e $\lambda_{2}>0$.

\subsubsection{Mutação Dinâmica}

Também chamada mutação não uniforme, é projetada para melhor sintonizar a capacidade de acerto, alcançando alta precisão. Permite que o valor de um gene seja modificado aleatoriamente dentro de sua faixa de variação viável de valores, resultando em modificação significativa para produção de boas soluções. A probabilidade de mutação pela qual os genes são alterados pode ser reduzida com o progresso das gerações, e pode ajudar nas últimas gerações, para refinar as soluções.

\subsubsection{Operadores baseados na direção}

\subsubsection{Cruzamento}

São definidos pela introdução de direção de gradientes aproximados (sub-gradientes) ou pela direção negativa nos operadores genéticos (cruzamento e mutação). Com os operadores anteriormente discutidos, segundo Gen e Cheng (1997) não existem garantias de que os descendentes serão melhores que os pais. Para operadores baseados na direção, o conhecimento específico do problema é introduzido na operação genética para produzir descendentes melhorados. 
O cruzamento dessa categoria usa os valores da função de aptidão na determinação da busca genética. O operador gera um único descendente $\mathrm{x}^{\prime}$ de dois pais $x_{1}$ e $x_{2}$, de acordo com a seguinte regra:

$$
x^{\prime}=r^{*}\left(x_{2}-x_{1}\right)+x_{2}
$$

onde $r$ é um número aleatório entre [0,1]. Também se assume que o "pai” $x_{2}$ não é pior que o "pai" $x_{1}$, isto é, os valores de fitness $f\left(\mathrm{x}_{2}\right) \geq f\left(\mathrm{x}_{1}\right)$, para problemas de maximização e $f\left(\mathrm{x}_{2}\right) \leq$ $f\left(\mathrm{x}_{1}\right)$ para problemas de minimização.

\subsubsection{Mutação}

A mutação baseada na direção é dada pela expansão da série de Taylor de uma função diferenciável $f$ contínua. O descendente após a mutação é $\mathrm{x}^{\prime}=\mathrm{x}+\mathrm{r}^{*} \mathrm{~d}$, onde $r$ é um número aleatório real positivo, $d$ é a direção aproximada determinada pela expansão da série de Taylor, tal que o descendente x', é uma solução viável.

\subsubsection{Mutação tipo Creep}

Neste tipo de mutação, dois genes vizinhos são modificados entre si. A Figura 3.13 exemplifica o processo de mutação em questão (MINER JUNIOR et al, 2001). 
Cromossomo antes da mutação

\begin{tabular}{|l|l|l|l|l|l|l|l|l|l|l|l|}
\hline 1 & 0 & 0 & 0 & 1 & 1 & 1 & 1 & $\mathbf{1}$ & $\mathbf{0}$ & 1 & 1 \\
\hline
\end{tabular}

Cromossomo após a mutação

\begin{tabular}{|l|l|l|l|l|l|l|l|l|l|l|l|}
\hline 1 & 0 & 0 & 0 & 1 & 1 & 1 & 1 & $\mathbf{0}$ & $\mathbf{1}$ & 1 & 1 \\
\hline
\end{tabular}

Figura 3.13 - Mutação tipo creep

\subsection{OPERADOR INVERSÃO}

Segundo Cui e Kuczera (2003), o operador inversão é aplicado independentemente e após os operadores de seleção, cruzamento e mutação terem produzido a nova geração de indivíduos. A idéia por trás da inversão é produzir regras que beneficiem a preservação de material genético, que se deseje manter nos indivíduos da população. Segundo os autores, o operador ajuda o cruzamento a escapar de um ótimo local. A Figura 3.14 exemplifica o operador inversão proposto por Cui e Kuczera (2003):

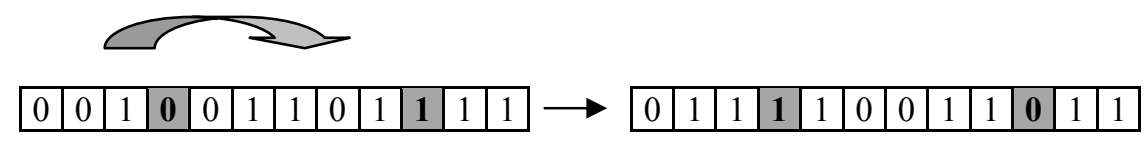

Figura 3.14 - Operador inversão 


\subsection{AG'S BINÁRIOS x AG'S CONTÍNUOS}

A experiência de Haupt e Haupt (1998) indica que o AG do tipo contínuo é melhor que o binário tanto para funções suaves quanto para as altamente oscilatórias. Mas não é sempre o caso.

É dispensável converter valores de parâmetros para números binários e preocupar-se com o número de bits necessários para representar um parâmetro. AG’s de parâmetros contínuos também são compatíveis com outros algoritmos de otimização sendo então, mais fácil combinar e hibridizar.

Para Michalewicz (1992):

"Os experimentos conduzidos indicam que a representação floating-point é mais rápida, mais consistente de iteração para iteração e fornece alta precisão (especialmente com grandes domínios, onde a codificação binária exigiria representações proibitivamente longas)'”.

\subsection{FUNÇÃO DE PENALIDADE}

É talvez a técnica mais comumente usada para manipular soluções inviáveis nos AG's para problema de otimização restrita. Em essência, a técnica transforma um problema restrito em irrestrito pela penalização das soluções inviáveis, técnica essa onde o termo penalidade é adicionado à função de aptidão ou objetivo por qualquer violação das restrições.

Na otimização convencional, a técnica de penalidade é usada para gerar seqüências de pontos inviáveis onde o limite é uma solução ótima para o problema original. 
Em AG's, é usada para manter a quantidade de soluções inviáveis em cada geração tal, que force a busca genética na direção da solução ótima de ambos os lados, das regiões viáveis e inviáveis.

No caso de otimização convencional, o maior cuidado é como encontrar um valor apropriado de penalidade que apresse a convergência e evite conclusão prematura.

Em AG's, a maior preocupação é determinar o termo de penalidade que encontre um balanço entre a preservação das informações (mantendo algumas soluções inviáveis) e a pressão seletiva (rejeitando algumas soluções inviáveis), assim como evitar a sub e superpenalidade.

O valor da penalidade corresponde à "quantidade" de inviabilidade dentro segundo alguma medida.

\subsubsection{Classificação da função de penalidade}

As funções de penalidade podem ser classificadas em:

- Penalidade constante - menos eficiente e,

- Penalidade variável - taxa de penalidade variável (ajustada para o número de iterações e grau de violação de restrições) e quantidade de penalidade para violação de restrições.

Essencialmente, PENALIDADE é uma função da distância da área viável, podendo ser distância absoluta, distância relativa das soluções inviáveis e em função do termo de penalidade adaptativa. 


\subsection{PARÂMETROS DOS AG's}

O primeiro estudo intensivo referente aos parâmetros de AG's segundo Haupt e Haupt (1998), foi feito por De Jong ${ }^{6}(1975)$, traduzindo teorias de Holland (1975) em uma função prática de otimização. O trabalho de De Jong (1975) é responsável pelos parâmetros em suo dos AG's até hoje.

Usou duas medidas de desempenho para julgar os AG's. Primeiro definiu performances on-line como uma média de todos os custos da geração corrente. Penalizou o algoritmo para fitness muito pobres de forma a achar rapidamente a direção dos menores custos (tendência).

No segundo momento, definiu o desempenho off-line como melhor custo obtido por exploração de áreas de altos custos da superfície de custos. Utilizou 6 (seis) tipos de AG's com complexidades crescentes e concluiu que:

$1^{\mathrm{o}}$. Pequenas populações melhoraram o desempenho inicial enquanto as grandes populações melhoraram o desempenho a longo prazo. Sugere populações de tamanho entre 50 e 100 cromossomos;

$2^{\circ}$. Altas taxas de mutação foram boas para desempenho off-line, enquanto baixas taxas foram boas para desempenho on-line. Sugere valor de 0,001 ;

$3^{\circ}$. Taxas de cruzamento deveriam ser de $60 \%$;

$4^{\text {o }}$. Tipos de cruzamento (ponto único versus pontos múltiplos) fizeram pouca diferença.

\footnotetext{
${ }^{6}$ DE JONG, K. A., Analysis of the behavior of a class of genetic adaptive systems. Ph.D. Dissertation, University of Michigan, Ann Harbor, 1975.
} 
Conjuntos de parâmetros são sensíveis às funções objetivo, opções de tipos de AG's, condições de contorno nos parâmetros e indicadores de desempenho. Conseqüentemente, comenta De Jong (1975), diferentes estudos resultam em diferentes conclusões sobre valores ótimos dos parâmetros.

Para Reis e Akutsu (2002), pode-se dizer que a literatura oferece diversas possibilidades de implementação para os AG's e seus operadores, bem como a definição de seus parâmetros de controle, tais como tamanho da população, probabilidades de recombinação e mutação, condição de finalização e tipo de substituição dos indivíduos pais pelos indivíduos filhos produzidos. Uma das dificuldades no uso dos AGs, além do fato de não se ter garantia de determinação do ótimo global, é a falta de padronização na sua utilização. Cada usuário explora os conceitos envolvidos de maneira diferente e a melhor implementação para uma aplicação particular não é tão óbvia, requerendo investigações ou certa experiência por parte do usuário. É prudente que diferentes alternativas e valores para os parâmetros sejam investigados para assegurar que um bom desempenho seja atingido. 


\section{MATERIAL E MÉTODOS}

Neste capítulo serão apresentados a área de estudo escolhida, o estudo de caso e o método utilizado para obtenção da operação otimizada via AG's.

\section{1. ÁREA DE TRABALHO: ESTUDO DE CASO}

A pesquisa proposta foi aplicada a uma alça de adução de água tratada, integrante da Região Metropolitana de São Paulo (RMSP), o SAM Leste, cuja metodologia possa ser aplicável para todo Sistema Adutor Metropolitano (SAM).

Foram feitas visitas ao Centro de Controle Operacional (CCO), onde pôde ser observado o dia-dia da operação em diferentes períodos do dia.

Em um espaço de tempo de três meses, foram feitos os levantamentos dos dados necessários à edição do modelo de simulação hidráulica, junto à Sabesp, assim como a confirmação de muitos dados incompletos ou duvidosos.

Durante o período de edição do modelo simulador, da sua calibração, desenvolvimento do modelo de otimização que durou cerca de 2 anos, manteve-se um contato mais constante junto ao CCO, a Divisão de Consumo de Energia e Automação, ao Departamento de Desenvolvimento Operacional da Produção e Divisão de Processos de Água, da Companhia de Saneamento Básico do Estado de São Paulo (SABESP).

Foi disponibilizado pela concessionária, arquivos do SCOA (sistema tipo SCADA) com registros históricos horários da operação do SAM Leste em base ACCESS (.mdb), do dia 01/01/2002 até 31/12/2002, em termos de status operacional de cada bomba dos boosters, 
pressões na sucção e/ou recalque, vazões de entrada nos reservatórios, níveis nos reservatórios e torres e consumos da rede. O critério para escolha dos dados para calibração da rede deu-se pela qualidade dos registros em termos poucas falhas de comunicação de dados, nos dias 02/02/2002 e 06/05/2002, da 0:00h até às 23:00h.

Em virtude da opção por considerar como mais significativo em termos de investigação, o período de 24 horas entre as 6:00h da manhã até as 6:00h do dia seguinte, que é quando efetivamente a rede começa a ser solicitada, preferiu-se o período das 6:00h do dia 05/06/2002 até às 6:00h do dia 06/05/2002, como dia típico da calibração e otimização.

$\mathrm{Na}$ fase inicial de calibração, pretende-se reproduzir em regime permanente a operação instantânea do SAM Leste e para tanto, escolheu-se às 18:30h do dia 06/05/2002, pois nesse instante, não havia nenhum problema de transmissão dos dados das estações remotas da rede para o CCO.

Apenas na fase de validação da calibração, utilizou-se os dados em regime permanente do dia 02/02/2002 às 7:26h, sem alteração da topologia da rede nem dos parâmetros de rugosidade calibrados, para verificar se o modelo reproduziria com outro dia, a operação do SAM Leste.

$\mathrm{Na}$ fase seguinte, a idéia seria verificar se o SAM Leste é controlável e otimizável e então a simulação se dará em período estendido de $24 \mathrm{~h}$, a partir das 6:00h do dia 05/05/2002 até o dia 06/05/2002, às 6:00h da manhã.

Para a otimização da operação, foi mantido o período de 24 h do dia 05/05/2002 às 6:00h até o dia 06/05/2002, às 6:00h da manhã.

Para desenvolvimento do modelo de rede a ser utilizado tanto no otimizador como no simulador, foram levantados os registros cadastrais junto à Sabesp, referentes ao estado e a topologia da rede, seus componentes e regras de operação da RMSP, a saber: 
- Diâmetros das adutoras e acessórios,

- Material das adutoras e acessórios,

- Comprimento das adutoras,

- Cotas dos nós, adutoras, válvulas, entrada e fundo dos reservatórios, sucção e recalque dos boosters,

- Dimensões dos reservatórios,

- Pressões nos nós e adutoras,

- Níveis operacionais dos reservatórios e torres,

- Vazões aduzidas,

- Regime de acionamento Estações Elevatórias e Boosters,

- Curvas de vazão recalcada x altura manométrica e especificação das bombas dos boosters,

- Tarifas de energia elétrica praticadas no período,

- Regime contratual de operação junto à concessionária de energia,

- Consumos e demandas de energia elétrica

- Regras de manobras das válvulas

- Níveis dos reservatórios e

- Dados de consumos, presentes como registros de dados do sistema de monitoramento da rede SCOA (tipo $S C A D A$ ).

\subsubsection{Descrição do sistema}

O sistema em estudo, apresentado esquematicamente pela Figura 4.1, possui 10 reservatórios (incluindo o Reservatório de Distribuição na saída da ETA Taiaçupeba), 75.6 
km de adutoras, 1 estação elevatória, 3 Boosters e 6 válvulas de controle de pressão e 9 de controle de vazão, com uma demanda total de 6.4391/s, para o dia típico estudado. O “Reservatório de Distribuição" é abastecido pelo Sistema Produtor Alto Tietê, que distribui uma vazão de $8,5 \mathrm{~m}^{3} / \mathrm{s}$ para o SAM Leste.

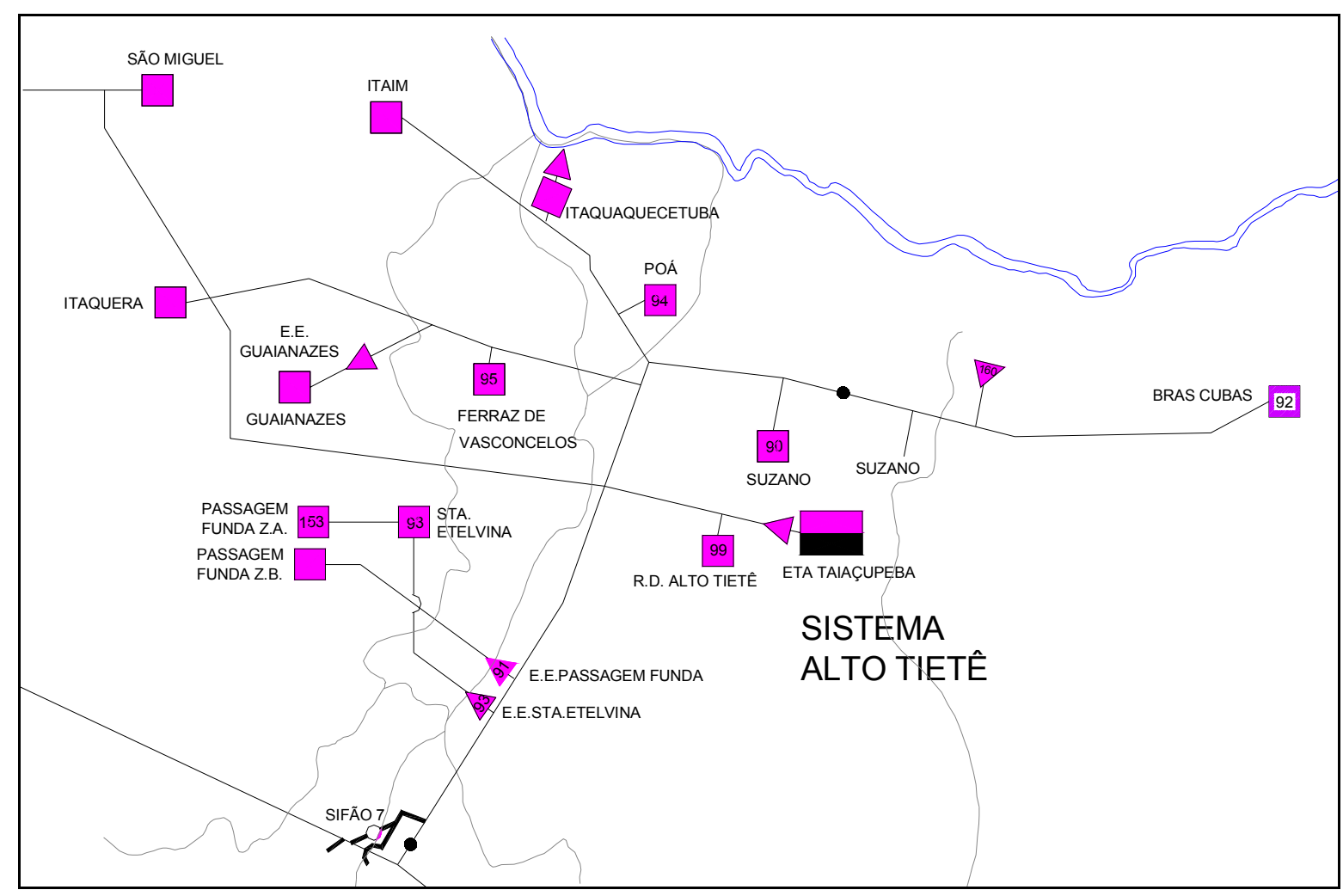

Figura 4.1 - Topologia do SAM Leste da R.M.S.P

\section{Legenda:}

= reservatório;

$\triangle$ = booster ou estação elevatória;

$\square=$ ETA Taiaçupeba

$\longrightarrow=$ adutoras 
A topologia do SAM Leste é apresentada conforme o modelo de simulação hidráulica Epanet 2.0 (ROSSMAN, 2000) na Figura 4.2:

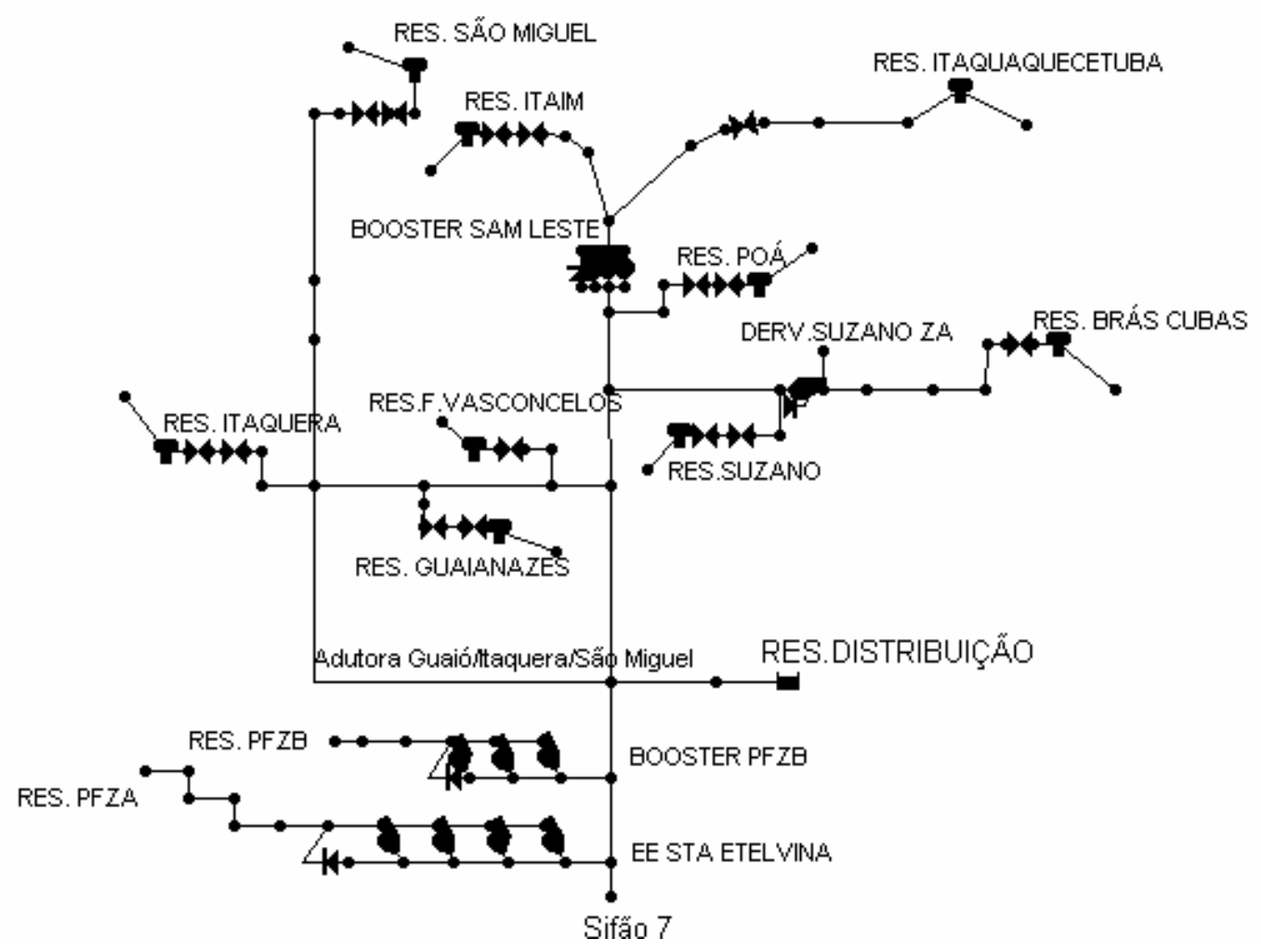

Figura 4.2 - Topologia do SAM Leste no modelo Epanet 2.0

\section{Legenda:}

W = válvula de controle de vazão ou de pressão;

- $\quad$ = nó de demanda ou conexão;

P = reservatório setorial;

= reservatório de distribuição;

$\bullet$ = adutora ou derivação;

战 $=$ by-pass;

= grupo moto-bomba com sucção à esquerda e recalque à direita 
De acordo com Borges (2003), o SAM Leste tem como limites físicos definidos: os Reservatórios Brás Cubas, Itaquaquecetuba, São Miguel, Itaim e Itaquera. Além destes reservatórios, foram considerados como limites os nós de demanda para os Reservatórios Passagem Funda Zona Alta e Zona Baixa, o nó do Sifão 7. Estes nós de demanda além da derivação do Reservatório Suzano para a Zona Alta, foram considerados desta forma por insuficiência de dados cadastrais.

A topologia do SAM Leste considerada neste estudo, conforme apresentada na Figura 4.1, é composta por:

- Reservatórios Guaianazes, Suzano, Itaquera, Poá, Itaim e São Miguel com tubulação de entrada por cima;

- Reservatórios Brás Cubas, Ferraz de Vasconcelos e Itaquaquecetuba com entrada por baixo;

- Reservatório de Distribuição (RD) da Estação de Tratamento de Água Taiaçupeba, que alimenta suficientemente todo o sistema;

- Pontos de demandas sem reservação: Sifão 7, Reservatórios Passagem Funda Zona Alta, Passagem Funda Zona Baixa e Derivação do Reservatório Suzano para Zona Alta;

- Boosters e estações elevatórias, com velocidade de rotação constante: Estação Elevatória Santa Etelvina com quatro grupos moto-bombas (3 operando x 1 reserva), Boosters Passagem Funda Zona Baixa com três grupos moto-bombas (2 operando x 1 reserva), SAM Leste com três grupos moto-bombas (2 operando x 1 reserva) e Brás Cubas com um conjunto moto-bomba. 
Após o Reservatório Itaquaquecetuba, existe uma saída da adutora com a derivação, que transporta água tratada para os Reservatórios Pinheirinho, Vila Industrial, Arujá que somados, levam cerca de $65 \%$ da vazão aduzida a montante do Reservatório Itaquaquecetuba. Como o volume de água que é aduzido para o Reservatório Itaquaquecetuba é muito maior que o consumo do seu setor, as vazões que são derivadas para os reservatórios acima foram inclusas na curva de demanda do Reservatório Itaquaquecetuba.

A Estação Elevatória Santa Etelvina eleva a carga piezométrica aduzida até o Reservatório Passagem Funda Zona Alta, assim como o Booster Passagem Funda Zona Baixa aumenta a pressão da água até o Reservatório Passagem Funda Zona Baixa. Ambos os reservatórios são resumidos a um ponto de demanda no modelo pela dificuldade de informações cadastrais disponíveis.

O Reservatório Guaianazes não possui válvula de controle na entrada, sendo operado através do acionamento de bombas do Booster Guaianazes, a montante. Por não se dispor de curvas de bombas conhecidas no Booster Guaianazes, e sabendo que, com a operação do booster, seja qual for a perda de carga distribuída no trecho entre o booster e o reservatório, esta será compensada pelo bombeamento, então a topologia utilizada foi simplificada, controlando a pressão de sucção do booster via medidor de pressão e considerando o trecho com perda de carga distribuída tendendo a zero. O Reservatório Guaianazes é então, abastecido pelo reforço de pressão promovido pelo Booster Guaianazes. Os dados cadastrais utilizados na topologia do SAM Leste foram:

- Adutoras - comprimento, diâmetro e material da tubulação entre os nós. Os comprimentos, diâmetros e material de cada trecho entre nós apresentam-se em forma digital no Anexo 1;

- Nós que indicam mudança de diâmetro ou material da tubulação ou mudança do sentido da inclinação - cota (Anexo 1); 
- Reservatórios - diâmetros e cotas da laje de fundo do reservatório (Tabela 4.2);

- Reservatório da ETA Taiaçupeba - cota (Tabela 4.2);

- Pontos de demandas sem reservação - cotas (Tabela 4.3);

- Válvulas - cotas e diâmetros (Tabela 4.4);

- Boosters - dados das curvas das bombas (Tabela 4.5);

- Nós que representam o ponto de medição de pressão - cotas dos medidores de pressão secundários (Tabela 4.6);

A Tabela 4.1 apresenta os comprimentos totais das adutoras classificadas por diâmetro. Esses dados foram obtidos através de consulta à base de dados do cadastro técnico da Sabesp.

Tabela 4.1 - Resumo das dimensões das adutoras do SAM Leste

\begin{tabular}{|c|c|}
\hline $\begin{array}{c}\text { Diâmetro } \\
(\mathbf{m m})\end{array}$ & $\begin{array}{c}\text { Comprimento } \\
(\mathbf{m})\end{array}$ \\
\hline 300 & 1.036 \\
\hline 400 & 632 \\
\hline 600 & 7.586 \\
\hline 700 & 110 \\
\hline 750 & 7.664 \\
\hline 800 & 10.211 \\
\hline 900 & 6.943 \\
\hline 1.050 & 9.928 \\
\hline 1.200 & 5.017 \\
\hline 1.800 & 12.576 \\
\hline 2.100 & 12.100 \\
\hline 2.500 & 1.780 \\
\hline Total & 75.583 \\
\hline
\end{tabular}


A Tabela 4.2, apresenta os volumes nominais, as áreas e as cotas dos reservatórios cilíndricos, disponíveis no CADOP (Cadastro de Dados Operacionais), e por consulta à base de dados do cadastro técnico da Sabesp.

Tabela 4.2 - Características Físicas dos Reservatórios do SAM Leste

\begin{tabular}{|c|c|c|c|c|c|c|c|c|}
\hline Reservatórios & $\begin{array}{c}\mathrm{n}^{\mathrm{o}} \\
\mathrm{SCOA}\end{array}$ & $\begin{array}{l}\text { Cotas } \\
\text { fundo } \\
\text { SCOA } \\
\text { (m) }\end{array}$ & $\begin{array}{l}\text { Nível } \\
\text { máximo } \\
(\mathrm{m})\end{array}$ & $\begin{array}{l}\text { Nível } \\
\text { mínimo } \\
\text { (m) }\end{array}$ & $\begin{array}{c}\text { Diâmetro } \\
\text { Real } \\
\text { (m) }\end{array}$ & $\begin{array}{c}\text { Demanda } \\
\text { Média } \\
(1 / s)\end{array}$ & $\begin{array}{l}\text { Volume } \\
\text { Nominal } \\
\left(1000 \mathrm{~m}^{3}\right)\end{array}$ & $\begin{array}{l}\text { Volume } \\
\text { Ideal } \\
\left(1000 \mathrm{~m}^{3}\right)\end{array}$ \\
\hline Guaianazes & 25 & 816,50 & 8,08 & 0,65 & 29,34 & 624 & 5 & 11 \\
\hline Brás Cubas & 92 & 784,93 & 4,09 & 0,80 & 78,57 & 558 & 20 & 10 \\
\hline Suzano & 90 & 786,00 & 5,40 & 0,70 & 46,76 & 603 & 10 & 11 \\
\hline Itaquera & 22 & 780,00 & 5,88 & 2,70 & 69,63 & 1.179 & 24 & 20 \\
\hline F.Vasconcelos & 95 & 789,92 & 4,15 & 1,00 & 24,88 & 292 & 2 & 5 \\
\hline Poá & 94 & 787,93 & 5,00 & 0,60 & 38,36 & 288 & 5 & 5 \\
\hline Itaim & 24 & 783,00 & 7,60 & 0,90 & 48,69 & 1.103 & 15 & 19 \\
\hline Itaquaquecetuba & 96 & 782,00 & 7,90 & 0,90 & 66,45 & 1064 & 15 & 8 \\
\hline São Miguel & 23 & 783,41 & 8,50 & 0,85 & 38,60 & 729 & 10 & 13 \\
\hline
\end{tabular}

A Tabela 4.3 apresenta as cotas nos pontos de demanda, levantadas por consulta à base de dados do cadastro técnico da Sabesp.

Tabela 4.3 - Pontos de demanda de água na representação do SAM Leste.

\begin{tabular}{|c|c|c|}
\hline Pontos de Demanda & $\mathrm{n}^{\circ}$ SCOA & Cota $(\mathrm{m})$ \\
\hline Sifão 7 & 137 & 770,00 \\
\hline Passagem Funda ZB & 156 & 864,62 \\
\hline \hline Passagem Funda ZA & 153 & 866,00 \\
\hline Derivação Suzano ZA & $90 \mathrm{F02}$ & 758,40 \\
\hline
\end{tabular}

A Tabela 4.4 apresenta as informações de cotas e diâmetros de válvulas de controle de vazão, levantadas a partir do CADOP. 
Tabela 4.4 - Dados cadastrais das válvulas telecomandadas nas entradas dos reservatórios de parte do SAM Leste

\begin{tabular}{|l|c|c|}
\hline \multicolumn{1}{|c|}{ Reservatórios } & $\begin{array}{c}\text { Cota } \\
\text { Válvula } \\
(\mathrm{m})\end{array}$ & $\begin{array}{c}\text { Diâmetro } \\
\text { Válvula } \\
(\mathrm{m})\end{array}$ \\
\hline Guaianazes & 784,37 & 0,40 \\
\hline Brás Cubas & 783,17 & 0,60 \\
\hline Suzano & 765,50 & 0,80 \\
\hline Itaquera & 788,70 & 1,05 \\
\hline Ferraz de Vasconcelos & 797,00 & 0,40 \\
\hline Poá & 787,00 & 0,40 \\
\hline Itaim & 781,63 & 0,90 \\
\hline Itaquaquecetuba & 782,00 & 0,80 \\
\hline São Miguel & 783,41 & 0,90 \\
\hline
\end{tabular}

As curvas características das bombas, apresentadas na Tabela 4.5, são conhecidas por meio de cadastro, a serem introduzidas no modelo simulador (informação pessoal) ${ }^{7}$.

Tabela 4.5 - Dados das curvas características das bombas dos Boosters e Estações Elevatórias

\begin{tabular}{|c|c|c|c|c|c|c|c|}
\hline \multicolumn{2}{|c|}{$\begin{array}{l}\text { E.E. SANTA } \\
\text { ETELVINA }\end{array}$} & \multicolumn{2}{|c|}{$\begin{array}{l}\text { B. PASSAGEM } \\
\text { FUNDA ZB }\end{array}$} & \multicolumn{2}{|c|}{ B. SAM LESTE } & \multicolumn{2}{|c|}{ B. BRÁS CUBAS } \\
\hline $\begin{array}{l}\text { Vazão } \\
(1 / s)\end{array}$ & $\begin{array}{c}\text { AMT } \\
(\mathrm{m})\end{array}$ & $\begin{array}{c}\text { Vazão } \\
(1 / s)\end{array}$ & $\begin{array}{l}\text { AMT } \\
(\mathrm{m})\end{array}$ & $\begin{array}{c}\text { Vazão } \\
(1 / s)\end{array}$ & $\begin{array}{l}\text { AMT } \\
(\mathrm{m})\end{array}$ & $\begin{array}{c}\text { Vazão } \\
(1 / s)\end{array}$ & $\begin{array}{c}\text { AMT } \\
(\mathrm{m})\end{array}$ \\
\hline 0 & 70 & 0 & 80 & 0 & 55 & 0 & 55 \\
\hline 20 & 68 & 278 & 75 & 200 & 52 & 200 & 52 \\
\hline 40 & 64 & 478 & 65 & 300 & 50 & 300 & 50 \\
\hline 60 & 58 & 586 & 65 & 400 & 48 & 400 & 48 \\
\hline 80 & 54 & & & 500 & 45 & 500 & 45 \\
\hline \multirow[t]{8}{*}{105} & 50 & & & 600 & 43 & 600 & 43 \\
\hline & & & & 700 & 40 & 700 & 40 \\
\hline & & & & 800 & 37 & 765 & 38 \\
\hline & & & & 900 & 34 & & \\
\hline & & & & 1000 & 31 & & \\
\hline & & & & 1100 & 28 & & \\
\hline & & & & 1200 & 25 & & \\
\hline & & & & 1300 & 19 & & \\
\hline
\end{tabular}

\footnotetext{
${ }^{7}$ HAGUIUDA, C. Potência de bombas. Mensagem recebida por gracione@,hotmail.com em 30 jul. 2004.
} 
A Tabela 4.6 apresenta as informações de cotas dos medidores de pressão secundários, levantadas a partir do CADOP.

Tabela 4.6 - Cotas dos medidores de pressão secundários

\begin{tabular}{|l|c|}
\hline \multicolumn{1}{|c|}{ Reservatórios } & \multicolumn{1}{|c|}{$\begin{array}{c}\text { Cota } \\
\text { Medidor } \\
(\mathrm{m})\end{array}$} \\
\hline Booster Guaianazes & 784,23 \\
\hline Brás Cubas & 783,61 \\
\hline Suzano & 786,54 \\
\hline Itaquera & 782,33 \\
\hline Ferraz de Vasconcelos & 796,38 \\
\hline Poá & 790,77 \\
\hline Itaim & 782,67 \\
\hline Itaquaquecetuba & 781,29 \\
\hline São Miguel & 785,96 \\
\hline
\end{tabular}

\subsection{MÉTODO DE TRABALHO}

Este item apresenta o método utilizado para produzir a operação otimizada do SAM Leste, desde a calibração até o desenvolvimento do modelo otimizador, através dos AG's.

\subsubsection{Calibração}

No desenvolvimento do modelo simulador, optou-se por aplicar, para efeito de calibração do modelo, o simulador hidráulico Epanet 2.0, (ROSSMAN, 2000). Como um modelo previsional de consumos da rede em estudo, assumiu-se como previsão perfeita, os 
registros históricos disponibilizados pela Sabesp, cujo período do dia 05/05/2002 às 6:00h ao dia 06/05/2002 às 6:00h, foi adotado como dia típico, como anteriormente justificado.

$\mathrm{Na}$ fase inicial de calibração do modelo simulador hidráulico, foram primeiramente simulados com base nos dados levantados previamente, estados e características dos componentes da rede, do dia típico:

- Os coeficientes de rugosidade $\mathrm{C}$,

- Perdas de energia das tubulações,

- Capacidade dos reservatórios e seus níveis mínimos e máximos,

- Status dos equipamentos de bombeamento e suas especificações técnicas, assim como das válvulas,

- Vazões de entrada nos reservatórios,

- Pressões nos nós e,

- Curvas de consumos horários.

Nesta fase, a idéia da calibração é reproduzir em regime permanente, a operação do SAM Leste instantaneamente. Para tanto, definiu-se como pontos de controle da calibração, os nós imediatamente a montante das válvulas de controle de vazão dos reservatórios, os nós de demanda em marcha do Sifão 7 e derivação do Reservatório Suzano para Zona Alta do setor, o nó a montante da sucção do Booster Passagem Funda Zona Baixa e nó de jusante do recalque da Estação Elevatória Santa Etelvina.

Nos pontos de controle, são comparadas as pressões instantâneas calculadas pelo simulador hidráulico, com as registradas pelo SCOA (informação pessoal) ${ }^{8}$.

\footnotetext{
${ }^{8}$ BORGES, V.M. SCOA. Mensagem recebida por gracione@hotmail.com em 03 jun. 2003.
} 
Para validar esta calibração, utilizou-se também em regime permanente, os dados de operação do dia 02/02/2002 às 7:26h, sem alterar os parâmetros calibrados de coeficientes de rugosidade, de forma a verificar se o modelo reproduziria a operação do SCOA com outro cenário operacional de um dia diferente.

No momento seguinte, em regime estendido, atribuiu-se as demandas médias para cada válvula de controle de vazão, para os trechos com adução por gravidade, até os reservatórios. No caso dos trechos que são aduzidos com auxílio de bombeamento, majorouse a demanda média do setor na razão de $24 \mathrm{~h} / 21 \mathrm{~h}$, devido ao fato de ter se imposto ao modelo através de regras de controle, o desligamento dessas bombas no horário de pico de 3 horas de duração consecutivas, considerado das 17:00 às 20:00h.

Este ensaio serviu para verificar se o sistema é perfeitamente otimizável, isto é, se a regra "simples" funcionasse, não haveria necessidade do modelo otimizador.

Após essa fase, verificou-se a possibilidade da área estudada ser controlável e que ainda, fosse possível melhorar o desempenho da operação feita pelo CCO da Sabesp, da seguinte forma: após as simulações feitas, a idéia é observar se os reservatórios extravasavam ou esvaziavam e se atendiam ou não às demandas da rede ao longo das horas, impondo-se regras de controle no formato padrão do Epanet 2.0 (ROSSMAN, 2000) acima descritas.

Criou-se em seguida, com base na topologia de estudo já calibrada e validada, um modelo utópico, isto é, um modelo com as dimensões majoradas de seus componentes: reservatórios com capacidade triplicada, tubulações com diâmetros duplicados, mas com vazões derivadas para consumo mantidas, de forma que fosse verificado o comportamento do modelo se sobrasse capacidade de adução e de reservação.

Após a validação do modelo real e a criação do modelo utópico, estes foram submetidos à otimização operacional através dos AG's, verificando-se tanto a possibilidade 
de uma melhoria operacional referente àquela praticada na Sabesp quanto o comportamento dos AG's diante de um modelo real e um modelo superdimensionado em seu sistema adutor.

\subsubsection{Custos de Operação}

Nos custos de operação, serão considerados os custos referentes somente ao consumo de energia elétrica pelos boosters e estações elevatórias do SAM Leste, fornecidos via AG's, cujo modelo de otimização é descrito a seguir.

4.2.2.1. Implementação de AG's ao problema de operação do SAM Leste

O modelo de otimização tem interface com o modelo Epanet 2.0 via En2toolkit (ROSSMAN, 2000) e com banco de dados ACCESS do SCOA. Os dados fornecidos pelo modelo de simulação Epanet 2.0 (ROSSMAN, 2000) via toolkit e os registros históricos operacionais do SCOA da Sabesp (registros considerados como previsão perfeita), foram utilizados como dados de entrada para o algoritmo de otimização via técnica dos AG's, para que o próprio algoritmo forneça, pela aplicação dos operadores genéticos e evolucionários:

a) Os melhores cenários e regras operacionais, em termos de atendimento de demanda horária, vazão de adução e reservação ótima;

b) A estratégia ótima de funcionamento dos equipamentos de bombeamento em relação às tarifas de energia elétrica e ao horário de operação e, 
c) Quantidade de manobras de abertura/fechamento das válvulas.

\subsection{Função de Fitness}

Como os AG's são ferramentas aplicáveis à problemas irrestritos, tanto as restrições como os limites operacionais descritos a seguir, serão tratados como penalidades aplicadas à função aptidão (fitness).

De acordo com Deb (2000) e Ahmed e Sarma (2004), na maioria das aplicações com AG's a problemas de otimização restrita, a função de penalidade tem sido usada. No método de função de penalidade para tratar as restrições de desigualdade nos problemas de minimização, a função de fitness é definida como a soma da função objetivo e um termo de penalidade, o qual depende da violação da restrição.

Para Ahmed e Sarma (2004), a técnica de função de penalidade envolve um número de parâmetros de penalidade que devem ser tais, que obtenham as soluções viáveis em qualquer problema. Selecionar valores apropriados ou pesos de penalidade, segundo tais autores, é uma tarefa importante na problemática de tratar restrições.

No método proposto por Deb (2000), as restrições são manipuladas, utilizando função de fitness ajustável, que depende da população corrente.

Assim, desde que as soluções não sejam comparadas em termos tanto do valor da função objetivo quanto da informação da violação da restrição, não há necessidade de qualquer parâmetro de peso explícito. Entretanto, para evitar qualquer tendência de uma restrição em particular, todas são normalizadas.

Na presente pesquisa, o método proposto por Deb (2000) foi adaptado da seguinte forma: 
- Como há a necessidade da informação da violação da restrição, foram utilizados parâmetros de peso explícitos;

- Devido à disparidade de ordem de grandeza do valor das violações entre si, as restrições e inclusive o valor do custo de energia elétrica a ser minimizado, foram normalizados de forma que variassem de 0 a 1.

Assim, a função de fitness que otimizará a operação do SAM Leste fica estabelecida como a de minimização do custo de energia elétrica e das penalidades de violações, conforme as seguintes expressões:

O custo do consumo de energia elétrica das bombas ou custo real, em unidades monetárias/h, é expresso pela equação (4.1):

$$
\text { Custo } \operatorname{Re} a l=\sum_{h=1}^{24}\left[\sum_{i \in \phi}\left(\text { tarifaP } * \operatorname{Vaz} \operatorname{Re} c_{i} * A M T_{i}\right)+\sum_{i \in \phi}\left(\operatorname{tarifaFP} * \operatorname{Vaz} \operatorname{Re} c_{i} * A M T_{i}\right)\right]
$$

Para $h=1, \ldots, 24$ horas e $i=1, \ldots, 20$ variáveis.

Sendo:

$i=$ variáveis de decisão do problema;

tarifaP $=$ tarifa no horário de ponta em unidades monetárias $/ \mathrm{kW}$.h do conjunto moto-bomba $i$ pertencente a cada booster ou estação elevatória na hora $h$;

tarifaFP $=$ tarifa no horário fora de ponta em unidades monetárias $/ \mathrm{kW} . \mathrm{h}$ do conjunto motobomba $i$ pertencente a cada booster ou estação elevatória na hora $h$;

$\operatorname{VazRec}_{i}=$ vazão recalcada de cada conjunto moto-bomba $i$ acionado, na hora $h$, em $1 / \mathrm{s}$; $\mathrm{AMT}_{i}=$ altura manométrica de cada conjunto moto-bomba $i$, em metros e $\phi=$ conjunto dos boosters e estações elevatórias, ligados na hora $h$; 
Para normalizar o custo de energia elétrica, definiu-se ainda o custo mínimo de operação dos boosters como sendo aquele em que todos os conjuntos moto-bombas estivessem desligados no período simulado, com os reservatórios sendo abastecidos por gravidade:

$$
\text { CustoMin }=0
$$

Também foi definido o custo máximo do consumo de energia elétrica destes equipamentos, para efeito de normalização do custo de energia elétrica, como sendo o custo de todas as bombas estarem operando nas 24 horas do dia, com uma vazão recalcada igual ao consumo médio de água. Assim, o custo máximo ficou definido pela equação 4.3:

$$
\text { CustoMáx }=\left(3 * A M T_{i} * \text { consumomed }{ }_{k}^{*} \text { tarifaP }\right)+\left(21 * A M T_{i} * \text { consumomed }_{k} * \text { tarifaFP }^{*}\right.
$$

Onde:

consumomed $_{k}=$ consumo médio do reservatório $k$;

O custo de energia elétrica normalizado é então expresso pela equação 4.4:

$$
\text { CustoEE }=1-\frac{(\text { CustoMáx }- \text { Custo Re } a l)}{(\text { CustoMáx }-0)}
$$

Ou ainda:

$$
\text { CustoEE }=1-\frac{(\text { CustoMáx }- \text { Custo Re al })}{(\text { CustoMáx })}
$$


Onde:

CustoEE $=$ Custo normalizado de energia elétrica, adimensional;

CustoMáx $=$ Custo fixo máximo de energia elétrica em unidades monetárias/kW.h

CustoReal $=$ Custo real de energia elétrica fornecido pela decisão operacional otimizada pelos AG's.

Para que a otimização seja eficiente, as restrições normalizadas impostas na forma de penalidades devem atender às seguintes condições, para que a função de aptidão atinja o mínimo:

- Atender à demanda horária aduzida para abastecimento do setor mantendo o nível de reservação flutuando entre os limites alto e baixo de operação;

- Respeitar os limites alto e baixo operacionais dos reservatórios durante o período de simulação de 24 horas, limites estes contidos entre os limites de extravasamento e esvaziamento dos reservatórios e,

- Considerar que o nível final dos reservatórios não pode estar abaixo do nível inicial ao final do período de simulação de 24 horas.

A formulação adotada das restrições é:

- Penalidade de nível final do reservatório $k$ estar abaixo do nível inicial (PenaNivIF)

$$
\text { PenaNivIF }=\sum_{k \in \phi 2}\left[\frac{N_{k}(1)-N_{k}(24)}{N_{k}(1)}\right]
$$

se $\mathrm{N}_{\mathrm{k}}(24)<\mathrm{N}_{\mathrm{k}}(1)$

ou

PenaNivIF $=0$ se $\mathrm{N}_{\mathrm{k}}(24) \geq \mathrm{N}_{\mathrm{k}}(1)$ 
onde:

$\phi_{2}=$ conjunto dos reservatórios do sistema;

$\mathrm{N}_{k}(1)=$ nível do reservatório $k$ na primeira hora de simulação, em metros;

$\mathrm{N}_{k}(24)=$ nível do reservatório $k$ no final do período de 24 horas de operação, em metros;

- Penalidade de nível do reservatório $k$ na hora $h$ estar abaixo do nível mínimo ou limite baixo operacional (PenaNivMin):

PenaNivMin $\} \begin{aligned} & =1 \text { se } N_{k}(h) \leq N_{k} \min \\ & =0 \text { se } N_{k}(h)>N_{k} \min \end{aligned}$

Onde:

$\mathrm{N}_{k \min }=$ limite baixo operacional do reservatório $k$, em metros;

- Penalidade de nível do reservatório $k$ na hora $h$ estar acima do nível máximo ou limite alto operacional (PenaNivMax):

$$
\left.\begin{array}{rl}
\text { PenaNivMax }
\end{array}\right\} \begin{aligned}
& =1 \text { se } N_{k}(h) \geq N_{k} \text { máx }, \\
& =0 \text { se } N_{k}(h)<N_{k} \text { máx }
\end{aligned}
$$

Onde:

$\mathrm{N}_{k \max }=$ limite alto operacional do reservatório $k$, em metros;

- Número de manobras nas válvulas que resultem em alterações das vazões aduzidas superiores a 20\% (PenaMan), definidos no modelo: número mínimo desejável de 3 manobras em $24 \mathrm{~h}$ por válvula ( 3 manobras x 9 válvulas $=27$ manobras no total). $\mathrm{O}$ número 
máximo é de 24 manobras por cada válvula $(24$ manobras x 9 válvulas $=216)$. Assim, a equação fica:

$$
\text { PENAMAN }=\left[\frac{(\text { somademan }(h)-\text { ManobraDesej })}{(\text { ManobraMax }- \text { ManobraDesej })}\right]
$$

Para

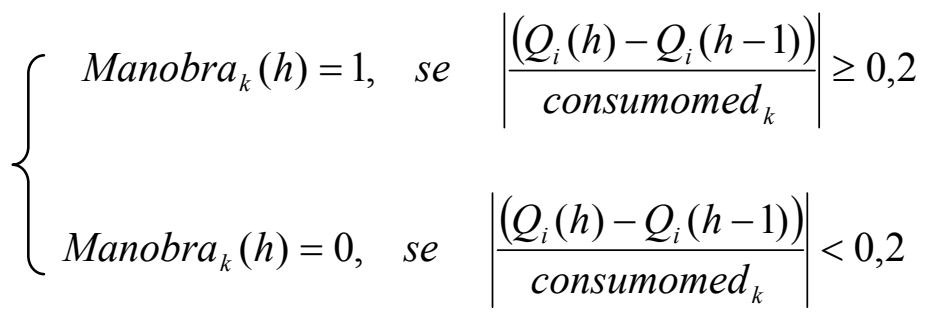

$$
\begin{aligned}
& \operatorname{somademan}(h)=\sum_{i \in \phi 3} \sum_{h=1}^{24} \operatorname{Manobra}_{i}(h)
\end{aligned}
$$

onde:

ManobraDesej = 3 manobras x número total de válvulas;

ManobraMax = 24 manobras x número total de válvulas;

$\operatorname{Manobra~}_{i}(h)=$ manobra na válvula com vazão $i$ na hora $h$ igual a 1 se maior ou igual que $20 \%$, e zero se menor que $20 \%$;

somademan $(h)=$ soma das manobras de todas as válvulas na hora $h$;

$\mathrm{Q}_{\mathrm{i}}(h)=$ vazão $i$ aduzida ao reservatório na hora $h$, em $1 / \mathrm{s}$;

$\phi_{3}=$ conjunto das vazões nas válvulas de controle de vazão do sistema;

Assim, a função objetivo a ser minimizada é expressa detalhadamente pela equação que definirá o fitness das soluções, a função de fitness, conforme a equação 4.12: 
Fitness $=$ Min $\{$ CustoEE + PenaNivIF + PenaNivMin + PenaNivMax + PenaMan $\}$

Os custos otimizados do sistema serão expressos como o somatório dos custos normalizados de consumo de energia elétrica e das penalidades, para o período de simulação de 24 horas.

\subsection{Energia Elétrica}

A demanda de energia elétrica corresponde à parcela fixa contratada de potência (em $\mathrm{kW}$ ), que no caso do SAM Leste é igual à capacidade total instalada em cada estação elevatória.ou booster, disponibilizada na rede elétrica pela concessionária e desta forma, o seu custo foi desconsiderado na função objetivo por independer das variáveis de decisão.

Todas as instalações dos grupos moto-bombas estão ligadas à rede de 13,8 kV com entrada primária em média tensão, segundo informações fornecidas pela Sabesp, se enquadrando na Tarifa Horosazonal Azul, sub-grupo A4, conforme praticado pela empresa Bandeirante, concessionária local.

Pelo fato de estarem sendo utilizados os registros dos dias 05/05 a 06/05/2002, as tarifas de consumo de energia elétrica consideradas são as do período seco do ano, de Maio a Novembro (informação pessoal) ${ }^{9}$.

A Concessionária Bandeirante, operadora da área de estudo, define como horário de ponta o compreendido das 17:30h às 20:30h. Em virtude de se estar utilizando discretização horária na simulação hidráulica por restrição do modelo simulador hidráulico Epanet 2.0

\footnotetext{
${ }^{9}$ HAGUIUDA, C. Enquadramento das instalações dos boosters do SAM Leste. Mensagem recebida por gracione@hotmail.com em 09 abr. 2003.
} 
(ROSSMAN, 2000), considerou-se como horário de ponta o período das 17:00h às 20:00h e o fora de ponta, as demais horas. Para o horário de ponta, a tarifa unitária praticada e aplicada no modelo é de R \$ 0.186/kW.h e para o horário fora de ponta, R \$ 0.090/kW.h.

\subsection{Variáveis de Decisão}

As variáveis de decisão, apresentadas na Tabela 4.7, são as soluções a serem investigadas no modelo de otimização via AG's, que compõem o string de 20 genes (variáveis) das soluções, totalizando 480 características em 24 horas de simulação, sendo 264 variáveis binárias do tipo 0/1 e 216 do tipo real.

As 11 primeiras variáveis de decisão do tipo binárias, igual a zero para bomba desligada, ou 1 (um) para bomba em operação, representam o status operacional dos equipamentos de bombeamento dos boosters e estações elevatórias do SAM Leste.

As demais 9 (nove) variáveis representam as vazões aduzidas aos reservatórios que passam nas válvulas de controle de vazão. Essas últimas são variáveis do tipo real de valor conhecido. Para inicializar os dados da otimização, foram considerados os valores das variáveis às 6:00h do dia 04/05/2002 até às 6:00h do dia 05/05/2002, fornecidos pelo SCOA da Sabesp, já que o período de simulação considerado no modelo hidráulico e no modelo de otimização é das 6:00h do dia 05/05/2002 às 6:00h do dia 06/05/2002, totalizando 24 horas simuladas. Vale ressaltar que a última hora simulada compreende o intervalo das 5:00 às 6:00h da manhã e não o valor às 5:00h e às 6:00h, pois somariam 25 e não 24 horas de operação. 
Tabela 4.7 - Descrição das variáveis de decisão

\begin{tabular}{|c|c|c|c|}
\hline \multicolumn{2}{|c|}{$\begin{array}{c}\text { ELEMENTOS DA } \\
\text { REDE }\end{array}$} & \multicolumn{2}{|c|}{ VARIÁVEIS DE DECIS $\tilde{A} O$} \\
\hline NOME & $\begin{array}{l}\text { CÓDIGO } \\
\text { USADO } \\
\text { EPANET }\end{array}$ & Descrição & Tipo \\
\hline Res.Guaianazes & 7025 & $\mathrm{i}_{12}=$ vazão entrada reservatório aduzida por gravidade. & $\begin{array}{l}\text { Real de valor conhecido } \\
(1 / \mathrm{s})\end{array}$ \\
\hline $\begin{array}{l}\text { Res .Brás Cubas } \\
\text { (Tarifa Azul) }\end{array}$ & 7092 & $\begin{array}{l}\mathrm{i}_{13}=\text { vazão entrada reservatório bombeada pelo Booster } \\
\text { Brás Cubas } \\
\mathrm{i}_{11}=\text { Booster Brás Cubas - }(\mathrm{L} / \mathrm{D})\end{array}$ & $\begin{array}{l}\text { Real de valor conhecido } \\
(1 / \mathrm{s}) \\
\text { Decisão Binária } 1 / 0\end{array}$ \\
\hline Res.Suzano & 7090 & $i_{14}=$ vazão entrada reservatório aduzida por gravidade & $\begin{array}{l}\text { Real de valor conhecido } \\
(1 / \mathrm{s})\end{array}$ \\
\hline Res.Itaquera & 7022 & $\mathrm{i}_{15}=$ vazão entrada reservatório aduzida por gravidade. & $\begin{array}{l}\text { Real de valor conhecido } \\
(1 / \mathrm{s})\end{array}$ \\
\hline $\begin{array}{l}\text { Res. Ferraz de } \\
\text { Vasconcelos }\end{array}$ & 7095 & $\mathrm{i}_{16}=$ vazão entrada reservatório aduzida por gravidade. & $\begin{array}{l}\text { Real de valor conhecido } \\
(1 / \mathrm{s})\end{array}$ \\
\hline Res.Poá & 7094 & $i_{17}=$ vazão entrada reservatório aduzida por gravidade. & $\begin{array}{l}\text { Real de valor conhecido } \\
(1 / \mathrm{s})\end{array}$ \\
\hline $\begin{array}{c}\text { Res. Itaim } \\
\text { (Tarifa Azul) }\end{array}$ & 7024 & $\begin{array}{l}\mathrm{i}_{18}==\text { vazão entrada reservatório bombeada pelo Booster } \\
\text { SAM Leste } \\
\mathrm{i}_{8}=\text { Booster SAM Leste (L/D) } \\
\mathrm{i}_{9}=\text { Booster SAM Leste (L/D) } \\
\mathrm{i}_{10}=\text { Booster SAM Leste (L/D) }\end{array}$ & $\begin{array}{l}\text { Real de valor conhecido } \\
(1 / \mathrm{s}) \\
\text { Decisão Binária } 1 / 0 \\
\text { Decisão Binária } 1 / 0 \\
\text { Decisão Binária } 1 / 0\end{array}$ \\
\hline $\begin{array}{l}\text { Res. } \\
\text { Itaquaquecetub } \\
\text { a } \\
\text { (Tarifa Azul) }\end{array}$ & 7096 & $\begin{array}{l}\mathrm{i}_{19}==\text { vazão entrada reservatório bombeada pelo Booster } \\
\text { SAM Leste } \\
\mathrm{i}_{8}=\text { Booster SAM Leste (L/D) } \\
\mathrm{i}_{9}=\text { Booster SAM Leste (L/D) } \\
\mathrm{i}_{10}=\text { Booster SAM Leste (L/D) }\end{array}$ & $\begin{array}{l}\text { Real de valor conhecido } \\
(1 / \mathrm{s}) \\
\text { Decisão Binária } 1 / 0 \\
\text { Decisão Binária } 1 / 0 \\
\text { Decisão Binária } 1 / 0\end{array}$ \\
\hline Res. São Miguel & 7023 & $\mathrm{i}_{20}=$ vazão entrada reservatório aduzida por gravidade. & $\begin{array}{l}\text { Real de valor conhecido } \\
(1 / \mathrm{s})\end{array}$ \\
\hline $\begin{array}{l}\text { Res. Passagem } \\
\text { Funda Zona } \\
\text { Alta (Tarifa } \\
\text { Azul) } \\
\end{array}$ & 9153 & $\begin{array}{l}\mathrm{i}_{1}=\text { Estação Elevatória Santa Etelvina }(\mathrm{L} / \mathrm{D}) \\
\mathrm{i}_{2}=\text { Estação Elevatória Santa Etelvina } \\
\mathrm{i}_{3}=\text { Estação Elevatória Santa Etelvina } \\
\mathrm{i}_{4}=\text { Estação Elevatória Santa Etelvina } \\
\text { (L/D) }\end{array}$ & $\begin{array}{l}\text { Decisão Binária } 1 / 0 \\
\text { Decisão Binária } 1 / 0 \\
\text { Decisão Binária } 1 / 0 \\
\text { Decisão Binária } 1 / 0\end{array}$ \\
\hline $\begin{array}{l}\text { Res. Passagem } \\
\text { Funda Zona } \\
\text { Baixa (Tarifa } \\
\text { Azul) } \\
\end{array}$ & 9156 & $\begin{array}{l}\mathrm{i}_{5}=\text { Booster Passagem Funda Zona Baixa (L/D) } \\
\mathrm{i}_{6}=\text { Booster Passagem Funda Zona Baixa (L/D) } \\
\mathrm{i}_{7}=\text { Booster Passagem Funda Zona Baixa (L/D) }\end{array}$ & $\begin{array}{l}\text { Decisão Binária } 1 / 0 \\
\text { Decisão Binária } 1 / 0 \\
\text { Decisão Binária } 1 / 0\end{array}$ \\
\hline
\end{tabular}

\subsection{Código-Fonte}

O código-fonte foi desenvolvido na linguagem Visual Basic versão 6.0 com interfaces para planilhas eletrônicas, banco de dados e gráficos em tempo de execução (programa em execução). Os resultados produzidos serão apresentados em planilhas e 
gráficos sendo gerado inclusive, um relatório do status final do sistema, conforme a verificação hidráulica fornecida pelo Epanet 2.0 (ROSSMAN, 2000), das soluções otimizadas pelos AG’s. O código-fonte é apresentado, na íntegra, no Anexo 2.

\subsection{Rotinas Computacionais}

O fluxograma típico dos programas desenvolvidos é mostrado na Figura 4.2, sendo descritos também o programa principal e as rotinas empregadas.

- O Programa Principal

O programa principal lê: o módulo de interface para o banco de dados tipo ACCESS, o módulo com a definição dos parâmetros PopSize, Iger, PCRUZ e PMUT, a serem utilizados pelos operadores genéticos (cruzamento e mutação), operador evolutivo (seleção) e nas avaliações da função de fitness (os respectivos valores são apresentados na Tabela 4.8). Lê também o módulo da biblioteca de funções (epanet2.dll) da En2toolkit do simulador Epanet 2.0 (ROSSMAN, 2000). 


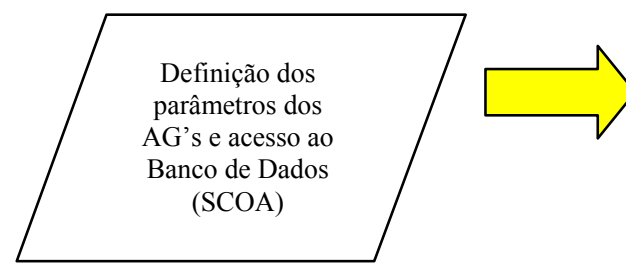

ROTINA Gerador: geração da população inicial de possíveis soluções.

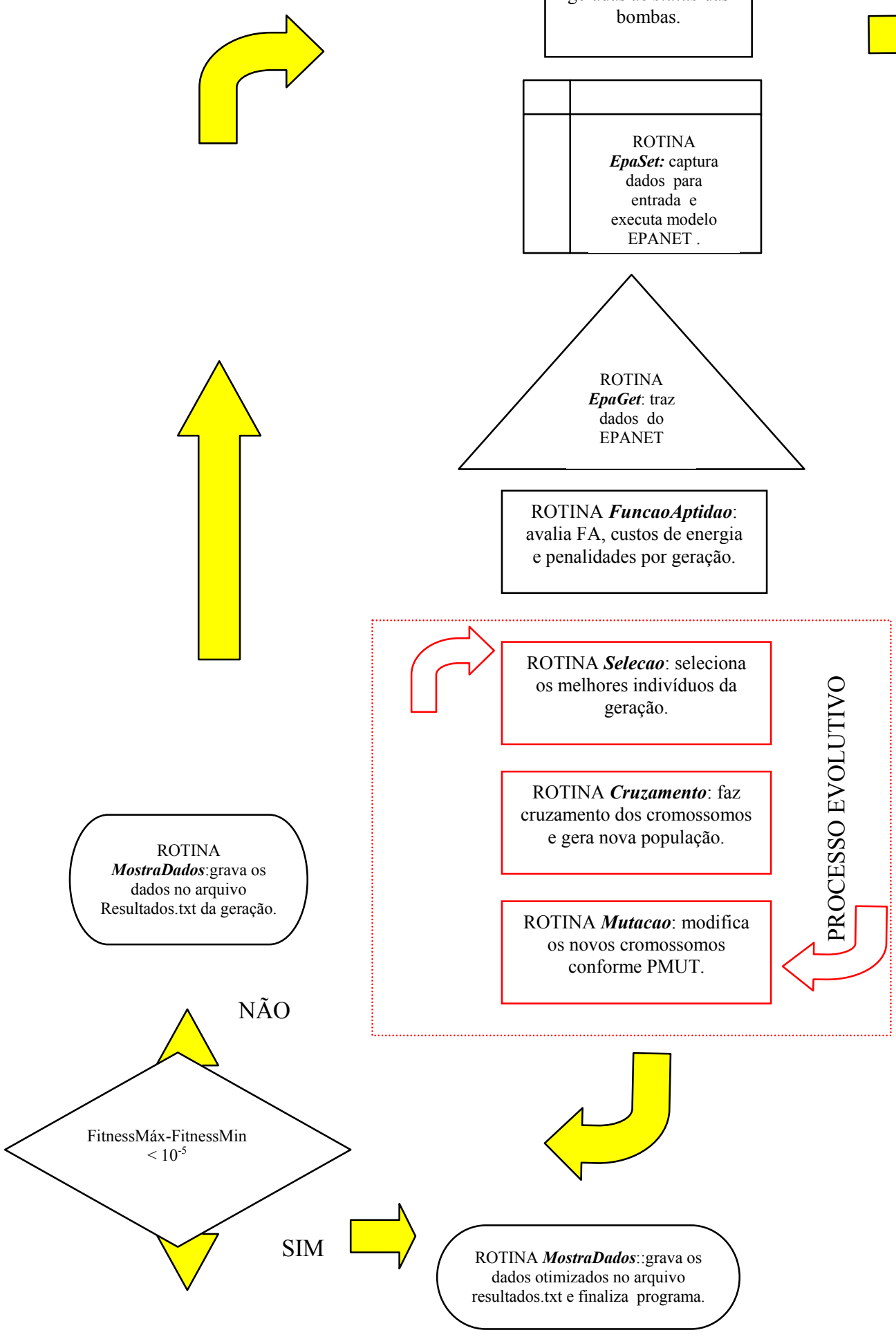

ROTINA Ajuste:

ajusta as vazões geradas ao status das bombas.
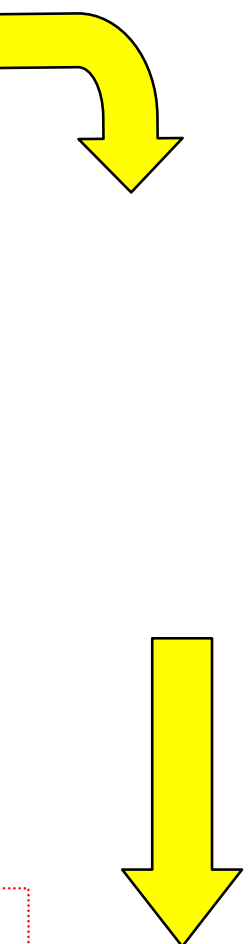

Figura 4.3 - Fluxograma do Programa Otimizador 
Tabela 4.8 - Parâmetros dos AG's utilizados no programa

\begin{tabular}{|l|c|}
\hline \multicolumn{1}{|c|}{ Parâmetro } & Valores \\
\hline PopSize & 10,200 \\
\hline Iger & $20,40,400$ \\
\hline PCRUZ & $30 \%, 50 \%, 80 \%$ \\
\hline TarifaAzulPonta(R\$/kW.h) & 0.18695 \\
\hline TarifaAzulForaPonta (R\$/kW.h) & 0.09 \\
\hline PMUT Penalidades & $0.2 \%, 0.5 \%, 1.0 \%$ e $10 \%$ \\
\hline \multicolumn{2}{|c|}{ Pesos } \\
\hline PenaNivIF & $0.05,0.10,0.60$ \\
\hline PenaNivMin & $0.10,0.20,0.30$ \\
\hline PenaNivMax & $0.05,0.10$ \\
\hline PenaMan & $0.05,0.10,0.20,0.30$ \\
\hline
\end{tabular}

Os valores das tarifas de energia elétrica são os praticados pela concessionária no período simulado e independem de análise de sensibilidade.

Os demais valores dos parâmetros dos AG's utilizados de acordo com a Tabela 4.8, foram estabelecidos segundo análise de sensibilidade preliminar de utilização do algoritmo. São eles:

PopSize = tamanho da população;

Iger = número de gerações a desenvolver;

PCRUZ $=$ probabilidade de cruzamento $(\%)$

PMUT $=$ probabilidade de mutação $(\%)$;

PESOS $=$ valores numéricos aplicados às penalidades PenaNivIF, PenaNivMin, PenaNivMax e PenaMan, respectivamente.

TarifaAzulPonta $=$ tarifa de energia elétrica horosazonal azul $(\mathrm{R} \$ / \mathrm{kW} . \mathrm{h})$ no horário de ponta; TarifAzulForaPonta $=$ tarifa de energia elétrica horosazonal azul $(\mathrm{R} \$ / \mathrm{kW} . \mathrm{h})$ no horário fora de ponta; 
Os pesos aplicados às penalidades poderiam ter assumido outros valores conforme opção de investigação. Os apresentados na Tabela 4.8 foram os efetivamente simulados.

No programa principal, são realizadas avaliações das gerações de AG's, através das rotinas: Gerador, Ajuste, EpaSet, EpaGet, FuncaoAptidao, Selecao, Cruzamento, Mutacao e MostraDados, descritas a seguir. São importados os dados de vazões de entrada dos reservatórios e status das bombas no intervalo das 6:00h do dia 04/05/2002 às 5:00h dia 05/05/2002 do modelo SCOA da Sabesp, através da interface com banco de dados tipo ACCESS, sendo então dados iniciais para rotina Gerador. No programa principal, também são dados de entrada os níveis mínimo e máximo dos reservatórios.

a) Rotina Gerador

A rotina Gerador produz a população inicial de possíveis soluções para os problemas (strings) em conformidade com os códigos estabelecidos, ou seja, inteiros 0/1, para representar as decisões das variáveis do tipo 0/1, mantendo desligadas ou ligadas as bombas, ou das variáveis reais, indicando as decisões relativas às vazões de entrada nos reservatórios. As decisões do tipo 0/1 são produzidas aleatoriamente, com o auxílio da função Rnd do VB. Depois de geradas são ajustadas para acionamento conforme consumo horário do setor abastecido. No caso das vazões aduzidas para os reservatórios, para atendimento da demanda, é gerado um número aleatório da mesma forma descrita acima, que multiplicado à diferença entre as vazões máxima e mínima observadas e somado ao valor de vazão mínima observado, passa a ser o valor atribuído a essa variável. 
b) Rotina Ajuste

Nesta rotina, são ajustados os status operacionais dos boosters e estações elevatórias, produzidos na rotina Gerador na primeira geração e os produzidos na Mutação, nas demais gerações. Para o Booster Brás Cubas e Estação Elevatória Santa Etelvina, o acionamento das bombas é ajustado para que a vazão de recalque seja suficiente para o atendimento do consumo horário do setor. Somente para o Booster SAM Leste as vazões de entrada produzidas pelos AG's são ajustadas. Se, pelo status operacional das bombas, a vazão de recalque for menor que a soma dos consumos médios setoriais dos Reservatórios Itaim e Itaquaquecetuba, as vazões são novamente geradas, utilizando a mesma sistemática da rotina Gerador, até que a soma das vazões de adução seja compatível com a vazão de recalque, conforme o status das bombas. Este ajuste é feito com as vazões produzidas pela rotina Gerador na primeira geração, e nas gerações seguintes com as soluções produzidas da rotina Mutacao.

c) Rotina EpaSet

A rotina EpaSet fornece ao modelo Epanet 2.0 (ROSSMAN, 2000) os dados de vazão e status das bombas produzidos pelos AG's, a partir da rotina Gerador, utilizando as regras de controle operacional (controls), presentes no arquivo de entrada (.inp) atualizado para cada solução. 
d) Rotina EpaGet

A rotina EpaGet executa com os dados da EpaSet, o modelo Epanet 2.0 (ROSSMAN, 2000) para período estendido de 24h. Obtém os resultados da simulação hidráulica em termos de carga dos reservatórios e pressões nos nós de controle da rede, mantendo o status das bombas e vazões de entrada dos reservatórios produzidos pelos AG's, repassados via regras de controle (controls) no arquivo de entrada (.inp).

e) Rotina FuncaoAptidao

Rotina FuncaoAptidao avalia o fitness de cada solução alternativa (indivíduo) de acordo com a equação 4.12 , de cada geração, composta por:

- custos de energia elétrica (CustoEE) e

- $\quad$ penalidades, que são calculadas quando:

(a) São produzidas soluções com volumes de armazenamento final do período de operação abaixo do inícial (PenaNivIF);

(b) São excedidas as capacidades de armazenamento dos reservatórios (PenaNivMax);

(c) Um volume de armazenamento inferior ao mínimo requerido (PenaNivMin) é produzido; 
(d) Soluções com vazões aduzidas através das válvulas iguais ou superiores a $20 \%$ em relação à vazão anterior, gerando assim uma manobra (PenaMan) são produzidas.

f) Rotina Selecao

A rotina Selecao define o número de cópias de cada solução alternativa de uma geração para a próxima, de forma que as soluções viáveis são mais enfatizadas que as inviáveis. Seguindo recomendações de Deb (2000), foi utilizado o operador seleção por torneio, onde duas soluções são escolhidas aleatoriamente a partir da população corrente e a melhor é escolhida. O operador seleção por torneio satisfaz os seguintes critérios:

(1) qualquer solução viável é preferida a qualquer solução inviável;

(2) entre duas soluções viáveis, escolhe-se a de menor violação das restrições, e

(3) entre duas soluções inviáveis, uma tem a menor violação das restrições e é escolhida.

Com a seleção por torneio, haverá uma pressão seletiva às soluções inviáveis direcionando a busca dos AG's para a região viável.

g) Rotina Cruzamento

A rotina Cruzamento realiza cruzamentos com probabilidade PCRUZ, através de trocas de pedaços do string para variáveis de decisão binárias, de características 
correspondentes (mesma posição), de maneira que a cada string só seja permitida uma operação de cruzamento por geração. Os strings cruzados (pais) produzem assim soluções alternativas descendentes (filhos). Para as variáveis reais foi utilizado o cruzamento aritmético, feito pela combinação linear de dois vetores (cromossomos).

h) Rotina Mutacao

A rotina Mutacao realiza mutação modificando cada característica do string, com probabilidade de mutação PMUT. Foi utilizada a mutação do tipo uniforme, voltada para os parâmetros contínuos (ou reais), definindo-se um novo valor dentro da faixa de valores aceitáveis para as variáveis, aleatoriamente. No caso das variáveis binárias $0 / 1$, utilizou-se o mesmo tipo de mutação só que voltada para os parâmetros binários, onde se substitui 0 (zero) por 1 e vice versa, conforme a probabilidade PMUT.

i) Rotina MostraDados

A rotina MostraDados grava o cenário das soluções otimizadas e o melhor indivíduo de cada geração no arquivo de resultados Resultados.txt.

\subsection{Consumos de Água}

Os dados de consumos ou demandas horárias nodais de água foram fornecidos pelo modelo SCOA (do tipo $S C A D A$ ) da Sabesp, com os valores referentes à vazão derivada para 
rede pelos reservatórios. Foram utilizadas no modelo de simulação hidráulica Epanet 2.0 (ROSSMAN, 2000) como dados de entrada (patterns de consumo) e considerados na simulação hidráulica de cada solução de AG’s.

- Consumos Horários de Água

O modelo hidráulico Epanet 2.0 (ROSSMAN, 2000) fornece para o otimizador no arquivo de entrada (.inp) de cada solução simulada, os valores de consumos nodais horários (patterns) de cada reservatório. Através dos controles operacionais (controls) via toolkit, o Epanet2.0 (ROSSMAN, 2000) recebe os dados das vazões de adução produzidas pelos AG's, simulando assim a rede hidraulicamente, com esse novo cenário operacional, verificando a oscilação de nível dos reservatórios ao longo do dia, e conseqüentemente, se atendem aos consumos horários (de acordo com os patterns) locais.

As curvas de consumo de cada reservatório e dos pontos de demanda em marcha considerados (Sifão7, Reservatório Passagem Funda Zona Alta, Reservatório Passagem Funda Zona Baixa e Derivação do Reservatório Suzano para Zona Alta), relativas ao intervalo das 6:00h do dia 05/05/2002 às 5:00h do dia 06/05/ 2002, são apresentadas na Figura 4.4.

Na base de dados do SCOA da Sabesp (em formato digital no Anexo 1), os consumos são representados pelos campos Y01 e um número qualificador que distingue a estação do SCOA. 


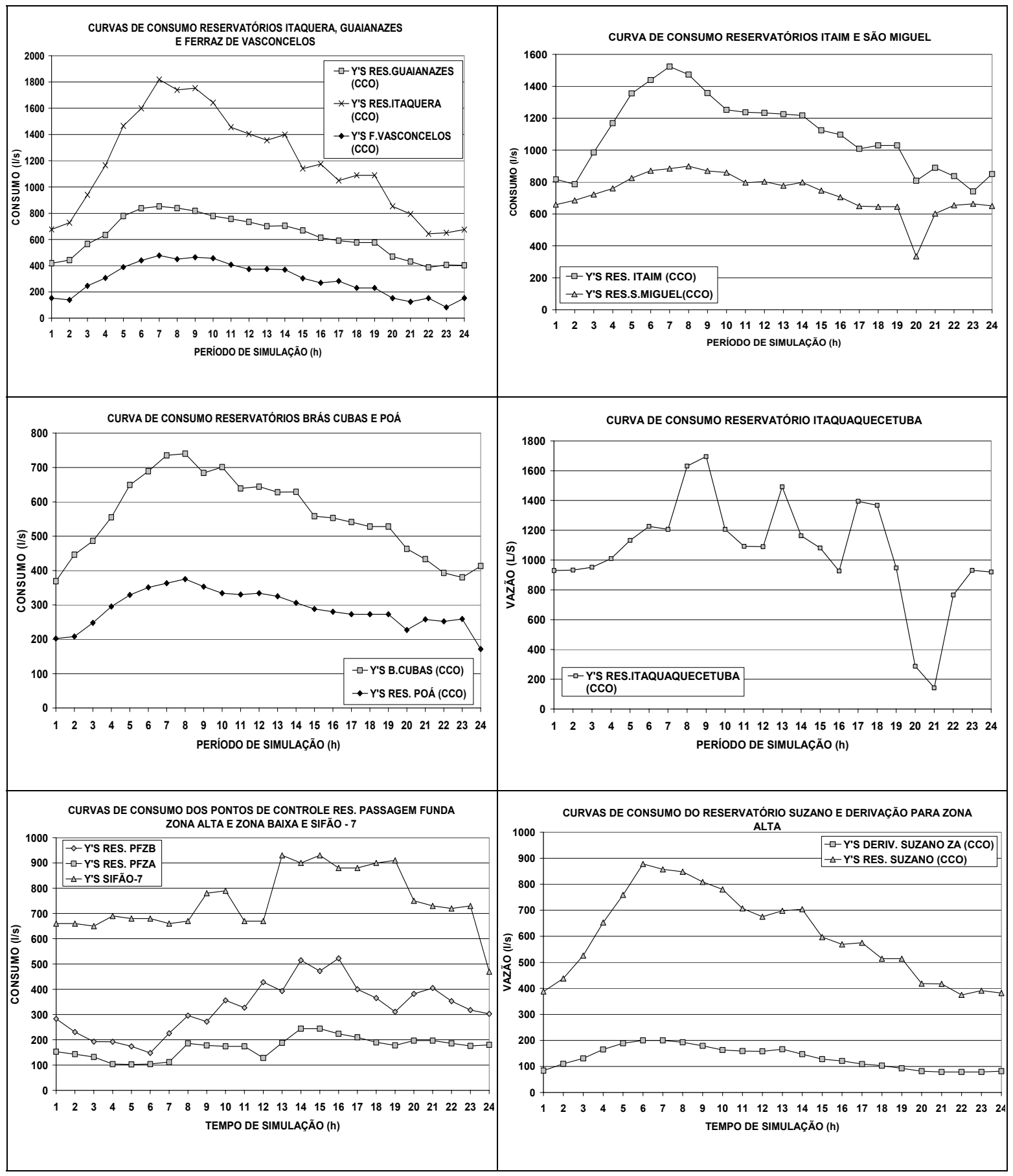

Figura 4.4 - Curvas de Consumo dos reservatórios e pontos de controle adotados 


\section{RESULTADOS}

A solução ótima ou um cenário das melhores soluções via AG's é a principal informação a ser dada pelo modelo de otimização da operação do SAM Leste, isto é, a regra operacional otimizada de acionamento dos grupos moto-bombas e as vazões aduzidas para os reservatórios, de forma a manter a oscilação de nível dos reservatórios dentro dos limites de esvaziamento e extravasamento e conseqüentemente, atendimento das demandas da rede.

Assim, o modelo otimizador decide automaticamente, acerca da regra operacional mais adequada para período estendido de $24 \mathrm{~h}$, verificado pela simulação hidráulica da rede via modelo Epanet 2.0 (ROSSMAN, 2000), contemplando as vazões aduzidas ótimas e o esquema ótimo de operação das bombas, conforme detalhado no capítulo anterior.

Para a saída de dados, optou-se pelas alternativas de visualização em planilhas eletrônicas e em gráficos, em tempo de execução do Visual Basic 6.0 com posterior gravação em arquivos de dados em formato de texto.

Serão apresentados neste capítulo, os resultados obtidos em termos de calibração do modelo simulador hidráulico, da estratégia operacional otimizada produzida pelos AG's em relação à praticada pelo Centro de Controle Operacional (CCO) da Sabesp, assim como a evolução da respectiva função de fitness para as soluções ótimas propostas.

\subsection{RESULTADOS DA CALIBRAÇÃO DO MODELO HIDRÁULICO}

A primeira fase de calibração do modelo Epanet 2.0 (ROSSMAN, 2000), verificouse com sucesso a reprodução instantânea da operação do CCO da Sabesp em regime 
permanente ou single period, às $18: 30 \mathrm{~h}$ do dia 06/05/2002. Nesta hora, dentro do dia típico de simulação escolhido, constavam os melhores registros operacionais fornecidos pelo SCOA da Sabesp, sem nenhuma falha na transmissão de dados entre as estações remotas e o CCO.

Nesta calibração em regime permanente, tomou-se como nós de controle para comparação das pressões com as registradas na base de dados do SCOA, aqueles nós imediatamente a montante das válvulas de controle de vazão dos reservatórios. Pretendeu-se assim, reproduzir as pressões registradas de operação nestes nós, instantaneamente. A idéia é que o modelo hidráulico estivesse nas mesmas condições de operação da rede, para simular mais realisticamente, sua operação.

Após estar calibrado, deveria ser validada a calibração, considerando os mesmos parâmetros e características da rede calibrados, apenas modificando o dia de operação a ser reproduzido com o modelo calibrado e verificando se as pressões nos nós de controle também seriam reproduzidas. A validação foi feita com os dados do dia 02/02/2002 às 7:26h.

O modelo reproduziu com sucesso a operação do SAM Leste do dia 02/02/2002, às 7.26h, validando assim, a calibração feita para os dados considerados do dia 06/05/2002, às $18: 30 \mathrm{~h}$.

Verificou-se na fase seguinte, se o SAM Leste seria otimizável, aplicando uma regra simples de operação em período estendido de 24 horas. Impôs-se então ao simulador hidráulico, através de regras de controle da operação no padrão do Epanet 2.0 (ROSSMAN, 2000), que os boosters e estações elevatórias ficassem fora de operação no horário de ponta (17:00h às 20:00h). Assim, os reservatórios abastecidos por bombeamento teriam suas demandas médias majoradas por um fator de $24 / 21=1.14$, e os reservatórios abastecidos por gravidade teriam seus consumos médios de água mantidos em valor sem majoração.

A simulação mostrou que o SAM Leste é otimizável, pois na simulação em período estendido, somente os Reservatórios Guaianazes e Itaquera não atendem às demandas no 
horário de pico de consumo. O Booster Passagem Funda Zona Baixa e Estação Elevatória Santa Etelvina necessitam de pelo menos um e dois equipamentos operando, respectivamente, para atender às demandas, isto é, quando da imposição da regra de não operação dos grupos moto-bombas no horário de ponta, ocorreu o não atendimento das demandas, já que não é possível vencer o desnível geométrico sem bombeamento. Os demais boosters e reservatórios não apresentaram problemas operacionais.

Assim, o sistema tem alguns pontos críticos em sua operação que podem ter melhor desempenho operacional, como é o caso da adutora que abastece os Reservatórios Ferraz de Vasconcelos, Guaianazes e Itaquera com uma regra mais ajustada. Outro ponto de difícil operação é o a adutora que abastece os Reservatórios Itaim e Itaquaquecetuba. Mas neste caso, os reservatórios atendem às demandas setoriais sem extravasar ou esvaziar.

A rede restante do sistema SAM Leste apresenta simulação sem problemas de não atendimento às demandas locais.

Pode-se então dizer com base nos resultados acima comentados, que o sistema é controlável, pois, pequenas alterações operacionais são impactantes na rede como todo.

Após essa fase, passou-se a verificar o comportamento do sistema em estudo, considerando-se um modelo utópico para o SAM Leste, com todos os elementos da rede majorados em dimensões e capacidade, mantendo-se apenas as vazões de entrada constantes, também em regime estendido de $24 \mathrm{~h}$. A simulação mostrou que com condições mais favoráveis de reservação e topologia, o SAM Leste é um sistema que atende às demandas setoriais, sem que os reservatórios esvaziem ou extravasem.

No que se refere à interface do modelo simulador com o modelo otimizador, serão comentados a seguir, o desenvolvimento da interface, dificuldades encontradas e resultados obtidos inclusive, da análise de sensibilidade para definir os parâmetros iniciais de operação dos reservatórios. 
Assim, a interface do modelo otimizador com o modelo de simulação Epanet 2.0 (ROSSMAN, 2000), verifica a viabilidade hidráulica de todas as soluções a cada geração propostas pelos AG's, considerando os dados da topologia da rede através arquivo de entrada (.inp), inclusive da solução ótima da geração corrente.

A edição da interface do modelo de simulação hidráulica Epanet 2.0 (ROSSMAN, 2000) com o otimizador, foi feita através da En2toolkit (ROSSMAN, 2000), com funções existentes para execução do simulador e avaliação para os nós e links. No modelo Epanet 2.0 são considerados como nós (nodes) os nós de conexão entre tubulações e os nós de demanda para rede, o reservatório de distribuição - RD (reservoir) e os reservatórios setoriais (tanks). Os links consideram as bombas, válvulas e tubulações de toda a rede. Esta nomenclatura em formato itálico são os termos padrão do Epanet 2.0 (ROSSMAN, 2000) e da sua toolkit.

As funções prontas presentes na toolkit avaliam os nós e links da rede, conforme as informações julgadas necessárias.

A rotina EpaSet captura a nova população produzida pelas rotinas Gerador (somente na 1. ${ }^{a}$ geração) e Mutação (durante a evolução), conforme já descrito no capítulo anterior. Da rotina EpaSet, são repassados pelo arquivo (.inp) para a rotina $\boldsymbol{E p a G e t , ~ o s ~ d a d o s ~ f o r n e c i d o s ~}$ pelos AG's o status operacional das bombas e as vazões de entrada nas válvulas de controle de vazão (flow control valve $-F C V$ 's). São usadas nesta rotina as funções para guardar os dados de status e settings, de cada indivíduo nas $24 \mathrm{~h}$, em matrizes tridimesionais.

$\mathrm{Na}$ rotina EpaGet, que captura os dados da rotina EpaSet, foram utilizadas as funções para abrir e fechar os arquivos (.inp) e executar a simulação hidráulica considerando as demandas nodais setoriais, escrever o relatório de simulação, calcular as pressões nos nós a montante das válvulas de controle de vazão, as carga nos tanks, o status operacional das bombas e as vazões de adução (setting nas $F C V^{\prime}$ 's), também para cada indivíduo nas 24 h de operação. 
Foram encontradas dificuldades na utilização da toolkit com relação a estas funções prontas. Algumas não apresentavam de forma clara, a sua tarefa ou que tipo de resultado forneceria se comparando com o software Epanet 2.0 (ROSSMAN, 2000) propriamente dito, como por exemplo, a função de simulação hidráulica EnrunH, que não indica claramente a forma de definir o tempo hora a hora na simulação. Fatos assim dificultam a automatização e a eficiência desta interface. Quando da necessidade de uma função inexistente na toolkit, não havia a permissão para inclusão ou edição no seu código-fonte.

\subsection{ANÁLISE DE SENSIBILIDADE E ÍNDICES UTILIZADOS NO MODELO OTIMIZADOR}

Para melhor definir o nível inicial de operação dos reservatórios, foram simulados os valores de 50, 70, 90 e 100\% de carga inicial de operação, calculado pela diferença entre os limites alto e baixo operacionais, multiplicado pelo valor que pretendia inicial a operação. A este valor foi adicionado o valor do limite baixo e assim definido o nível inicial de operação:

Nível inicial $($ Epanet $)=($ limite alto - limite baixo $) *$ valor $\%+$ limite baixo

A operação com nível inicial de 50\% forneceu somente soluções inviáveis operacionalmente, pois os reservatórios não conseguem atender às demandas e esvaziam sem se recuperar ao final das $24 \mathrm{~h}$.

A análise de sensibilidade mostrou que as configurações de simulação hidráulica que produzem soluções viáveis são as de carga inicial igual a 70\%, 90\% e 100\% da carga máxima dos reservatórios. 
Os melhores resultados são fornecidos considerando a carga inicial igual a $90 \%$ da carga máxima dos reservatórios, sendo esta então a condição inicial de operação mais investigada.

A partir de análise de sensibilidade dos modelos hidráulico e otimizador, optou-se por considerar que todos os reservatórios da rede tivessem "a priori” seu nível inicial a 90\% da carga máxima, e portanto foram os níveis considerados nas simulações dos resultados que serão apresentados neste capítulo.

Foram definidos para efeito de análise de desempenho do otimizador os seguintes índices, dados em percentual (\%):

- O índice de potência total utilizada por todos os equipamentos segundo os AG's em relação ao praticado pelo CCO da SABESP (INDICEPOT), em função do acionamento das bombas no período simulado de $24 \mathrm{~h}$, do melhor indivíduo;

- O índice de manobras (INDICEMANOBRA), definido como a razão entre a quantidade de manobras ou acionamento de todas as válvulas pelo praticado pelo Centro de Controle Operacional (CCO) da SABESP, do melhor indivíduo;

- O índice de oscilação de nível (ION) nos reservatórios, na razão da diferença entre o nível máximo e o nível mínimo observados na otimização, dividida pela diferença entre os limites máximo operacional (limite alto) e mínimo operacional (limite baixo), de cada reservatório da solução ótima e, 
- O índice de amplitude entre as vazões aduzidas a cada reservatório, na razão da diferença entre as vazões máxima e mínima, dividida pela vazão média, da solução ótima.

Segundo Sabesp (1999), o diagnóstico da reservação do SAM foi elaborado em função da determinação dos valores de volume nominal, útil e necessário dos reservatórios, e da determinação do Rendimento da Reservação $(R R)$ e da Ocupação do Reservatório $(O R)$.

Para melhor entendimento dos termos utilizados, são apresentadas a seguir algumas definições referentes aos reservatórios e condições de operação dos mesmos, e também a metodologia utilizada para o cálculo desses parâmetros.

- Volume nominal (Vnom.): É o volume total do reservatório, compreendido entre a laje de fundo do reservatório e o limite de extravasamento (de acordo com a Figura 5.1), conforme Sabesp (1999). Nos projetos, é definido de modo a receber uma vazão aduzida igual à demanda média diária do dia de maior consumo de sua área de influência e deve ser capaz de acumular água durante as horas em que a demanda é inferior à média e fornecer vazões complementares quando a vazão de demanda for superior à demanda média. Na operação deve, além disso, prover uma lâmina d'água mínima (para evitar entrada de ar na linha de saída) e uma folga superior (para garantir uma segurança operacional). 


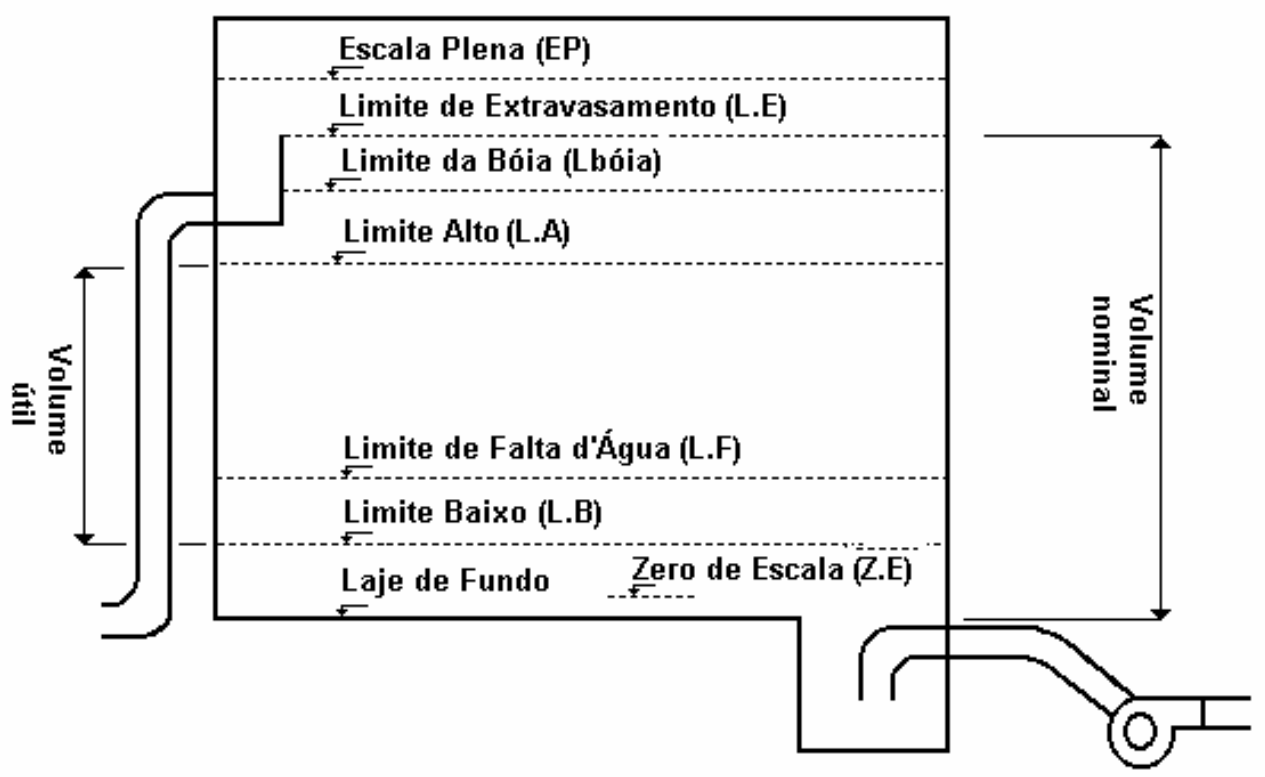

Figura 5.1 - Níveis operacionais dos reservatórios setoriais

- Volume útil (Vútil): É o volume compreendido entre o limite alto e o maior valor entre o limite baixo e o limite de falta d'água. Representa o volume efetivamente disponível para regularizar as demandas de consumo setoriais, e é determinado em função das restrições operacionais já citadas anteriormente.

- Volume necessário (Vnec.): É o volume necessário para regularizar as demandas diárias de consumo, admitindo-se uma vazão de adução constante, igual ao consumo médio diário. O cálculo do volume necessário é feito através dos dados de consumo horários e adução fixa horária, dos setores em ciclos diários de operação (24h). 
- Rendimento do Reservatório $(R R)$ : É a relação entre os volumes útil e nominal do reservatório, dada pela equação 5.1:

$$
R R(\%)=\frac{\text { Vútil }}{\text { Vnom }}
$$

Esse parâmetro é um bom indicador da eficiência da utilização do reservatório, e em função desse parâmetro, podem ser identificados aqueles com baixo rendimento, indicando a necessidade de análise mais detalhada dos limites operacionais.

- Ocupação do Reservatório $(O R)$ : É a relação entre os volumes necessário e útil do reservatório, dada pela equação 5.2:

$$
O R(\%)=\frac{\text { Vnec }}{\text { Vútil }}
$$

Esse parâmetro permite identificar os reservatórios com déficits de reservação, quando a capacidade útil é insuficiente para regularizar a demanda de consumo diário do setor.

Assim, para os reservatórios da área de estudo os índices de rendimento e a ocupação do reservatório, são apresentados na Tabela 5.1. 
Tabela 5.1 - Características operacionais dos reservatórios utilizadas nos modelos

\begin{tabular}{|l|c|c|c|c|c|c|}
\hline Reservatórios & $\begin{array}{c}\text { Volume } \\
\text { Nominal } \\
\text { Real } \\
\left(\mathrm{m}^{3}\right)\end{array}$ & $\begin{array}{c}\text { Volume } \\
\text { Nominal } \\
\text { Ideal } \\
\left(\mathrm{m}^{3}\right)\end{array}$ & $\begin{array}{c}\text { Volume } \\
\text { Útil } \\
\left(\mathrm{m}^{3}\right)\end{array}$ & $\begin{array}{c}\text { Volume } \\
\text { Neces- } \\
\text { sário } \\
\left(\mathrm{m}^{3}\right)\end{array}$ & $\begin{array}{c}\text { RR } \\
(\%)\end{array}$ & $\begin{array}{c}\text { OR } \\
(\%)\end{array}$ \\
\hline Guaianazes & 5.000 & 11.000 & 4.365 & 2.696 & 87.30 & 61.76 \\
\hline Brás Cubas & 20.000 & 10.000 & 15.062 & 5.770 & 75.31 & 38.31 \\
\hline Suzano & 10.000 & 11.000 & 7.833 & 3.079 & 78.33 & 39.31 \\
\hline Itaquera & 24.000 & 20.000 & 14.857 & 13.709 & 61.90 & 92.27 \\
\hline F.Vasconcelos & 2.000 & 5.000 & 1.531 & 4.506 & 76.55 & 294.33 \\
\hline Poá & 5.000 & 5.000 & 3.607 & 2.968 & 72.14 & 82.28 \\
\hline Itaim & 15.000 & 19.000 & 12.475 & 13.738 & 83.17 & 110.12 \\
\hline Itaquaquecetuba & 15.000 & 8.000 & 12.301 & 5.406 & 82.01 & 43.95 \\
\hline \hline São Miguel & 10.000 & 13.000 & 8.693 & 3.756 & 86.93 & 43.21 \\
\hline
\end{tabular}

Na Tabela 5.1 podem ser observados os volumes nominal, útil e necessário para regularização das demandas dos setores a serem abastecidos pelos reservatórios da área de estudo. Segundo informações do referido relatório, para o índice de rendimento de reservação $(R R)$ o valor mínimo aceitável é $70 \%$.

Assim, o Reservatório Itaquera possui rendimento de reservação aquém do limite mínimo aceitável.

No caso do índice de ocupação dos reservatórios $(O R)$, o máximo valor aceitável de ocupação é de 70\%. Analisando o índice $O R$ da Tabela 5.1, os Reservatórios Itaquera, Ferraz de Vasconcelos, Poá e Itaim, operam em condições críticas de reservação, indicando déficits de capacidade em 4 (quatro) de um total de 9 (nove) reservatórios do SAM Leste.

Vale ressaltar que os volumes nominais dos Reservatórios Ferraz de Vasconcelos e Itaim utilizados no modelo de simulação e de otimização são diferentes dos utilizados no relatório Sabesp (1999) e por isso o volume útil, $R R$ e $O R$ foram recalculados, para se adequarem aos volumes nominais utilizados nesta tese. Os comentários referentes ao índice $O R$ valem para estes valores recalculados. 
Observa-se ainda, que a maioria dos reservatórios da área estudada possui volume nominal real aquém do ideal, isto é, menor ou igual a $1 / 5$ da demanda diária $\left(\mathrm{m}^{3}\right)$, de acordo com a Tabela 5.1. Por esse motivo, grande é a dificuldade encontrada pelo algoritmo de operar esses reservatórios de maneira tal, que as vazões de adução sendo variáveis de decisão, se mantenham em patamares de variação razoáveis $(20 \%)$, e assim atender às restrições impostas na função de fitness.

Para melhor descrição do desempenho dos reservatórios do SAM Leste, conforme os níveis máximos e mínimos observados na operação otimizada, adotou-se neste estudo, o índice de oscilação de nível em relação ao índice $O R$. A formulação deste novo índice chamado ION_OR é:

$$
I O N_{-} O R(\%)=\frac{I O N}{O R}
$$

Como este índice depende da operação dos reservatórios produzidos pela otimização, estes serão apresentados nas planilhas resumo de cada otimização e nos arquivos disponíveis no Anexo 4, em meio digital.

Para uma melhor visualização do desempenho dos reservatórios quanto ao índice de oscilação de nível (ION), em relação ao índice ocupação dos reservatórios (ION_OR), criouse neste estudo uma escala em percentual, que qualifica o desempenho do reservatório em ruim, razoável, satisfatória e boa, ilustrada na Figura 5.2. 


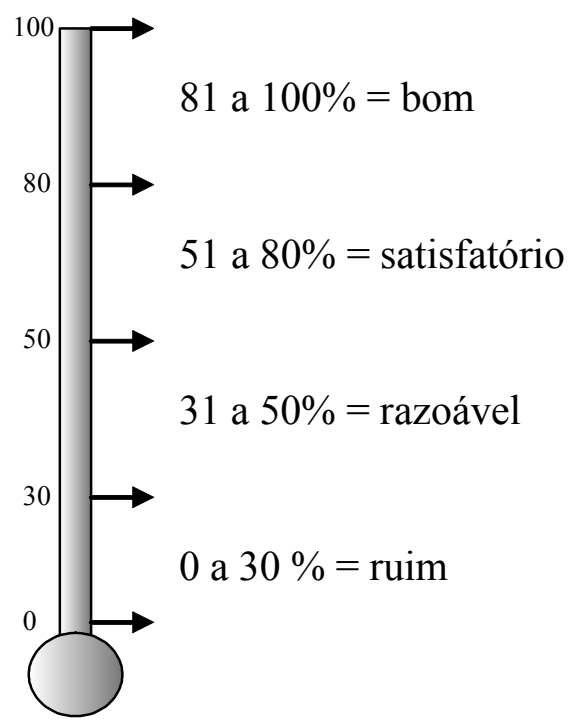

Figura 5.2 - Escala de desempenho dos reservatórios

A combinação de pesos aplicada à função de fitness e a nomenclatura utilizada foi a seguinte, de acordo com a Tabela 5.2:

Tabela 5.2 - Combinação de pesos aplicados à função de fitness

\begin{tabular}{|c|c|c|c|c|c|}
\hline Nomenclatura & CustoEE & PenaNivMin & PenaNivMax & PenaMan & PenaNivIF \\
\hline Não & - & - & - & - & - \\
\hline Tipo 1 & 0.10 & 0.10 & 0.10 & 0.10 & 0.60 \\
\hline Tipo 2 & 0.40 & 0.30 & 0.10 & 0.10 & 0.10 \\
\hline Tipo 3 & 0.60 & 0.20 & 0.05 & 0.10 & 0.05 \\
\hline
\end{tabular}

A primeira combinação sugere a não aplicação de pesos à função de fitness, deixando a definição dos melhores indivíduos de acordo com seus valores absolutos calculados pelos custos e penalidades. 
Na combinação de pesos Tipo 1, pretende-se que o AG privilegie soluções com níveis finais de operação mais próximos dos níveis iniciais, em detrimento das outras penalidades de nível, de manobras e também do custo adimensional de energia elétrica (CustoEE), que competem igualmente nas soluções.

Nos pesos Tipo 2, a idéia é que as soluções tenham prioritariamente menores custos adimensionais de energia, em seguida não violem os limites baixos dos reservatórios e com igual prioridade não violem o limite alto dos reservatórios, manobrem menos as válvulas e finalizem a operação com nível final mais próximo do inicial.

Na combinação Tipo 3, impõe-se que as soluções ótimas sejam aquelas com menores custos de energia, que em segundo plano não esvaziem os reservatórios, em seguida não manobrem muito as válvulas e por último com igual prioridade, não ultrapassem o limite alto dos reservatórios e finalizem a operação com nível final mais próximo do inicial.

A seguir serão apresentados os resultados obtidos, dentre os vários cenários operacionais otimizados pelos AG's do SAM Leste.

\subsection{RESULTADOS DO MODELO DE OTIMIZAÇÃO}

As simulações foram realizadas com dados do período das 6:00h do dia 05/05/2002 até às 6:00h do dia 06/05/2002, variando o número de gerações (Iger), tamanho da população (PopSize), probabilidades de mutação (PMUT), de cruzamento (PCRUZ), nível inicial de operação dos reservatórios e a utilização ou não, de combinações de pesos aplicados à função de fitness, cujos valores foram mostrados na Tabela 4.8 do capítulo anterior.

A Tabela 5.3 apresenta todos os cenários de otimização simulados que produziram soluções viáveis. 
Tabela 5.3 - Cenários otimizados do SAM Leste pelos AG's

\begin{tabular}{|c|c|c|c|c|c|c|c|c|c|c|}
\hline \multicolumn{11}{|c|}{ RESUMO DA OTIMIZAÇÃO DA OPERAÇÃOO DO SAM LESTE VIA AG'S } \\
\hline cenário & PESO & $\begin{array}{c}\text { Nível } \\
\text { inicial de } \\
\text { operação } \\
\text { (\%) }\end{array}$ & $\begin{array}{c}\text { PCRUZ } \\
\text { (\%) }\end{array}$ & $\begin{array}{c}\text { PMUT } \\
\text { (\%) }\end{array}$ & PopSize & Iger & $\begin{array}{l}\text { CustoEE } \\
\text { (adim.) }\end{array}$ & $\begin{array}{c}\text { IndicePot } \\
\text { AG/CCO } \\
\text { (\%) }\end{array}$ & $\begin{array}{c}\text { Indice } \\
\text { Manobra } \\
\text { AG/CCO } \\
\text { (\%) }\end{array}$ & $\begin{array}{c}\text { I.O.N_OR } \\
\text { MÉDIO } \\
(\%)\end{array}$ \\
\hline 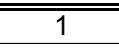 & NÃO & 90 & 30 & 10 & 10 & 20 & 0,41 & 82 & 206 & 105 \\
\hline 2 & TIPO 2 & 90 & 30 & 1 & 10 & 20 & 0,14 & 72 & 179 & 93 \\
\hline 3 & TIPO 2 & 90 & 30 & 0,2 & 10 & 20 & 0,17 & 83 & 195 & 102 \\
\hline 4 & TIPO 3 & 90 & 30 & 10 & 10 & 20 & 0,27 & 88 & 225 & 98 \\
\hline 5 & TIPO 2 & 90 & 30 & 0,2 & 10 & 400 & 0,14 & 71 & 68 & 85 \\
\hline 6 & TIPO 2 & 90 & 30 & 10 & 10 & 400 & 0,16 & 81 & 177 & 100 \\
\hline 7 & TIPO 3 & 90 & 30 & 10 & 10 & 400 & 0,24 & 79 & 202 & 88 \\
\hline 8 & TIPO 3 & 90 & 30 & 0,2 & 10 & 400 & 0,21 & 71 & 61 & 74 \\
\hline 9 & NÃO & 90 & 30 & 10 & 200 & 40 & 0,45 & 88 & 168 & 90 \\
\hline 10 & TIPO 1 & 90 & 30 & 1 & 200 & 40 & 0,035 & 71 & 43 & 83 \\
\hline 11 & TIPO 3 & 90 & 30 & 0,5 & 200 & 40 & 0,21 & 71 & 59 & 89 \\
\hline 12 & TIPO 3 & 90 & 30 & 10 & 200 & 40 & 0,24 & 79 & 156 & 77 \\
\hline 13 & NÃO & 90 & 50 & 1 & 10 & 20 & 0,37 & 74 & 100 & 112 \\
\hline 14 & NÃO & 90 & 50 & 0,2 & 10 & 20 & 0,37 & 74 & 181 & 97 \\
\hline 15 & NÃO & 90 & 50 & 10 & 10 & 20 & 0,49 & 88 & 193 & 97 \\
\hline 16 & TIPO 1 & 90 & 50 & 1 & 10 & 20 & 0,037 & 75 & 127 & 105 \\
\hline 17 & TIPO 1 & 90 & 50 & 0,2 & 10 & 20 & 0,038 & 77 & 186 & 102 \\
\hline 18 & TIPO 1 & 90 & 50 & 10 & 10 & 20 & 0,047 & 90 & 172 & 103 \\
\hline 19 & TIPO 2 & 90 & 50 & 0,2 & 10 & 20 & 0,15 & 78 & 179 & 106 \\
\hline 20 & TIPO 3 & 90 & 50 & 10 & 10 & 20 & 0,25 & 82 & 197 & 104 \\
\hline 21 & TIPO 3 & 90 & 50 & 10 & 10 & 400 & 0,24 & 81 & 200 & 98 \\
\hline 22 & NÃO & 90 & 70 & 0,2 & 200 & 400 & 0,35 & 71 & 61 & 90 \\
\hline 23 & NÃO & 70 & 70 & 0,2 & 200 & 400 & 0,35 & 71 & 61 & 85 \\
\hline 24 & TIPO 2 & 70 & 70 & 0,2 & 200 & 400 & 0,14 & 71 & 61 & 86 \\
\hline 25 & TIPO 3 & 90 & 80 & 0,2 & 200 & 400 & 0,21 & 94 & 181 & 93 \\
\hline 26 & NÃO & 70 & 80 & 0,2 & 200 & 400 & 0,35 & 71 & 61 & 92 \\
\hline 27 & TIPO 2 & 70 & 80 & 0,2 & 200 & 400 & 0,14 & 71 & 61 & 83 \\
\hline 28 & TIPO 2 & 70 & 80 & 1 & 200 & 40 & 0,14 & 72 & 61 & 100 \\
\hline 29 & TIPO 2 & 70 & 80 & 10 & 200 & 40 & 0,21 & 94 & 181 & 93 \\
\hline 30 & NÃO & 100 & 80 & 0,2 & 200 & 400 & 0,35 & 71 & 61 & 89 \\
\hline 31 & TIPO 2 & 100 & 30 & 10 & 10 & 20 & 0,19 & 97 & 204 & 104 \\
\hline 32 & TIPO 3 & 100 & 50 & 10 & 10 & 400 & 0,23 & 79 & 190 & 105 \\
\hline 33 & TIPO 3 & 100 & 70 & 10 & 200 & 40 & 0,22 & 75 & 202 & 95 \\
\hline
\end{tabular}

Como pode ser observado na tabela em análise, foram otimizados 33 cenários com diversas variações entre os níveis iniciais de operação, combinações de pesos, parâmetros de AG's de população, número de gerações, probabilidades de cruzamento e de mutação e que resultaram em diferentes custos de energia elétrica, potência consumida $(\mathrm{kW})$ na regra dos AG's em relação à do CCO (INDICEPOT), quantidade de manobras totais variadas propostas pelos AG's em relação ao $\mathrm{CCO}$ e oscilação de nível dos reservatórios em relação à sua ocupação. 
Os cenários $03,07,11,18,28$ e 30 ressaltados em amarelo, foram escolhidos para serem comentados com mais detalhes, por serem mais representativos da sensibilidade dos AG's aos diversos parâmetros escolhidos para cada cenário otimizado, dentre todos os apresentados na Tabela 5.3. Assim estes cenários foram resumidos na Tabela 5.4.

Tabela 5.4 - Cenários representativos da otimização com AG's

\begin{tabular}{|c|c|c|c|c|c|c|c|c|c|c|}
\hline \multicolumn{9}{|c|}{ CENÁRIOS OTIMIZADOS DA OPERAÇÕO DO SAM LESTE VIA AG'S } \\
\hline \hline cenário & PESO & $\begin{array}{c}\text { Nível } \\
\text { inicial de } \\
\text { operação } \\
(\%)\end{array}$ & $\begin{array}{c}\text { PCRUZ } \\
\text { (\%) }\end{array}$ & $\begin{array}{c}\text { PMUT } \\
(\%)\end{array}$ & PopSize & Iger & $\begin{array}{c}\text { CustoEE } \\
\text { (adim.) }\end{array}$ & $\begin{array}{c}\text { IndicePot } \\
\text { AG/CCO } \\
\text { (\%) }\end{array}$ & $\begin{array}{c}\text { Indice } \\
\text { Manobra } \\
\text { AG/CCO } \\
\text { (\%) }\end{array}$ & $\begin{array}{c}\text { I.O.N_OR } \\
\text { MÉDIO } \\
\text { (\%) }\end{array}$ \\
\hline \hline $\mathbf{3}$ & TIPO 2 & 90 & 30 & 0,2 & 10 & 20 & 0,17 & 83 & 195 & 102 \\
\hline $\mathbf{7}$ & TIPO 3 & 90 & 30 & 10 & 10 & 400 & 0,24 & 79 & 202 & 88 \\
\hline $\mathbf{1 1}$ & TIPO 3 & 90 & 30 & 0,5 & 200 & 40 & 0,21 & 71 & 59 & 89 \\
\hline $\mathbf{1 8}$ & TIPO 1 & 90 & 50 & 10 & 10 & 20 & 0,047 & 90 & 172 & 103 \\
\hline $\mathbf{2 8}$ & TIPO 2 & 70 & 80 & 1 & 200 & 40 & 0,14 & 72 & 65 & 100 \\
\hline $\mathbf{3 0}$ & NÃO & 100 & 80 & 0,2 & 200 & 400 & 0,35 & 71 & 61 & 89 \\
\hline
\end{tabular}

Os cenários escolhidos $03,07,11,18,28$ e 30 serão apresentados e comparados entre si, de forma a mostrar a sensibilidade dos AG's nas diversas configurações investigadas.

Tais cenários referem-se a diferentes combinações de pesos, níveis iniciais de operação dos reservatórios, PCRUZ, PMUT, populações e número de gerações desenvolvidas.

Estas configurações de otimização produziram diversas estratégias de operação, com diferentes consumos de energia, potência consumida pelos grupos moto-bombas em relação à regra do CCO (INDICEPOT), número de manobras dos AG's x CCO (INDICEMANOBRA) e desempenho dos reservatórios em termos de oscilação de nível e sua capacidade de atender às demandas (ION_OR).

A Figura 5.3 mostra a evolução de fitness para os vários cenários da Tabela 5.4. 


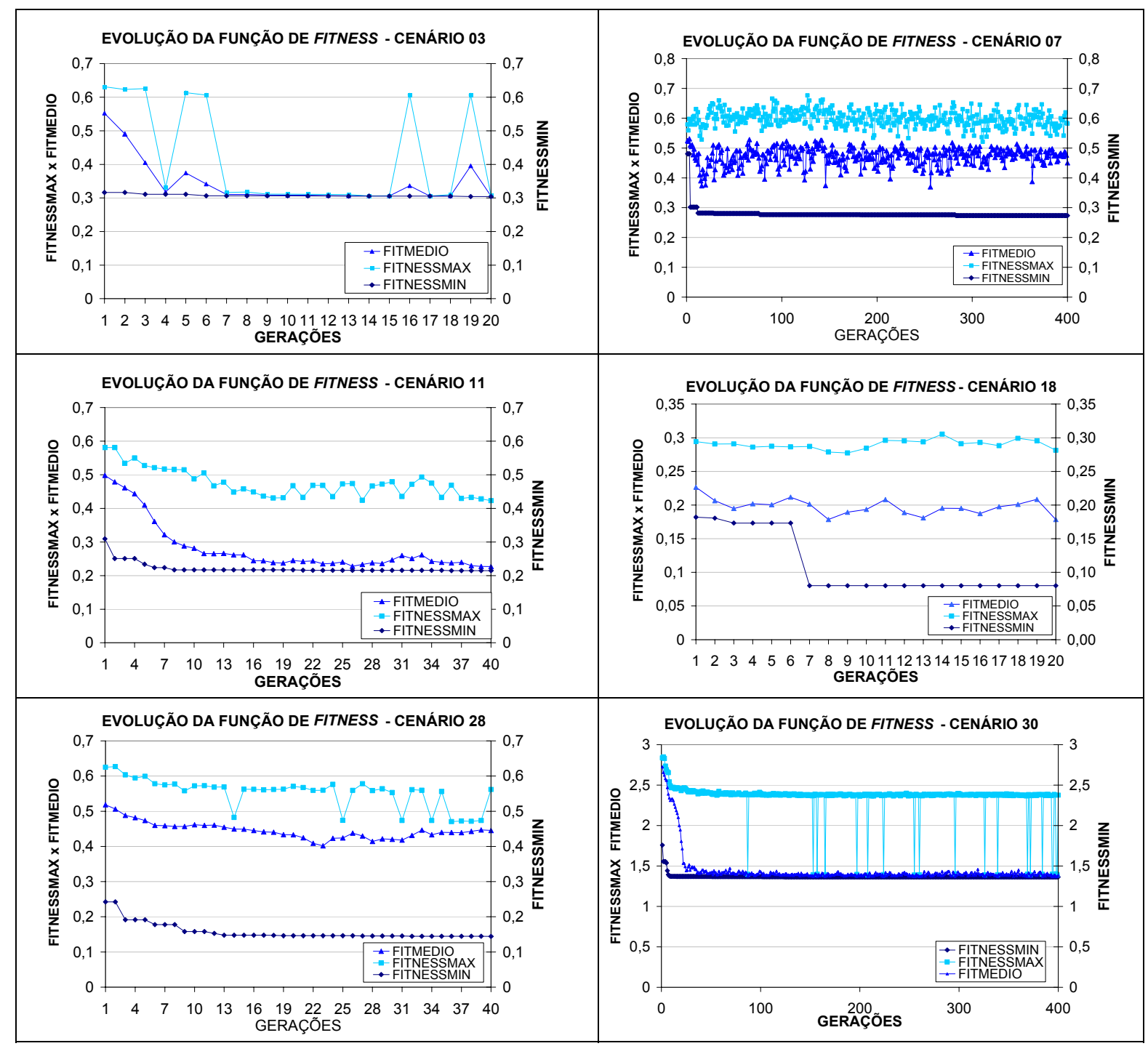

Figura 5.3 - Evolução de FitnessMax, Fitmedio e FitnessMin

Observa-se na Figura 5.3 que pequenas modificações nos parâmetros dos AG's de população, gerações a desenvolver, PCRUZ e PMUT alteram o comportamento da função de fitness em termos de convergência e da qualidade da solução ótima, visto que as dimensões, a forma de exploração e de explotação do espaço de busca são diferentes, mostrando a sensibilidade dos AG's a estes parâmetros e aos pesos aplicados, inclusive.

No cenário 03, por exemplo, a configuração de otimização aplicada gera uma evolução da função de fitness que atinge o critério de convergência proposto, na maior parte 
da evolução, inclusive na última geração. O critério de convergência é que se a diferença entre o fitness do pior indivíduo (FitnessMax) e o fitness da solução ótima da geração corrente (FitnessMin), fosse menor que $10^{-5}$. Neste caso, o AG converge. Mesmo com poucas gerações para evolução genética, a busca por boas soluções obteve êxito, já que se observa a convergência do modelo na maior parte das gerações.

Pelo fluxograma básico apresentado no capítulo anterior, deveria haver interrupção do modelo e sua finalização, mas neste cenário, esta opção foi desativada pela curiosidade da investigação e também pelo período de evolução que era curto.

No cenário 07, modificou-se a PMUT para 10\%, o número de gerações para 400 e os pesos aplicados para tipo 3 e observa-se uma evolução mais instável e sem convergência, com o FitnessMin minimizando seus valores mais acentuadamente nas primeiras gerações e com poucas melhoras até a $400 .^{\text {a }}$ geração.

No cenário 11, aumentou-se a população para 200 indivíduos (maior e mais diverso espaço de busca), reduziu-se a PMUT para 0.5\% (menos perturbação aleatória) e as gerações para 40, mas manteve-se o restante das configurações. Observa-se então uma evolução mais estável da função de FitnessMax, FitMedio (fitness médio da população) e FitnessMin. Mesmo que com pouca evolução genética em 40 gerações, os valores de FitnessMin e FitMedio apresentam tendência de aproximação, mostrando que na média, os indivíduos da população estão melhores por se aproximar dos melhores valores de fitness.

Optou-se então, por uma estratégia de pesos mais suave (tipo 1), aumentando a PMUT para 10\% (mais alterações) e a quantidade de troca de informações genéticas, com a PCRUZ de $50 \%$, agora reduzindo-se o espaço de busca para 10 soluções em 20 gerações, apresentadas no cenário 18. Observou-se que a evolução assume uma tendência de aproximação das curvas de FitnessMin e FitMedio nas primeiras gerações, para após uma mudança provável na direção 
da busca decorrente da mutação, ocorrer um comportamento divergente nas curvas de FitnessMax, FitnessMin e FitMedio.

No cenário 28 , a combinação de pesos é mais restritiva, assim como a condição inicial de operação dos reservatórios. Aumentou-se mais ainda a quantidade de soluções que são cruzadas aplicando uma PCRUZ $=80 \%$, espaço de busca com 200 indivíduos e período de evolução para 40 gerações, mas a perturbação aleatória da PMUT agora de $1 \%$ é menor. $\mathrm{O}$ resultado é que as curvas de FitnessMax, FitnessMin e FitMedio sofrem um lento processo de minimização, mantendo-se distantes de qualquer convergência.

Retirando-se qualquer aplicação de pesos, para a mesma população e PCRUZ, favorecendo a operação inicial dos reservatórios para 100\% do nível máximo, introduzindo-se baixa mutação $(0.2 \%)$ para o maior período evolutivo de 400 gerações, o cenário 30 apresenta uma evolução de fitness com vários momentos de convergência, apesar de ocorrerem em "pulsos".

Assim, verificou-se que o tamanho da população e a forma de exploração e explotação do espaço de busca atribuídas aos operadores genéticos de cruzamento e mutação, assim como o direcionamento da busca ao espaço de soluções viáveis através dos pesos, influenciam fortemente o desempenho dos AG's quanto à qualidade das soluções ótimas obtidas. Estes aspectos também foram verificados por Deb (2000).

Há divergências na literatura sobre os valores recomendados para a probabilidade de cruzamento a ser adotada. De Jong (1975) já recomendava 60\%, Haupt e Haupt (1997) indicam 50\% e Wardlaw e Sharif (1999) recomendam 70\%. Van Zyl et al. (2004) utilizaram 90\% de probabilidades de cruzamento e mutação. Gen e Cheng (1997) indicam para probabilidade de mutação o inverso do tamanho do string (1/string) e Goldberg (1989) recomenda o inverso do tamanho da população (1/população). 
Observa-se que não há um consenso na literatura sobre os valores mais recomendados, mas há sim a recomendação desta autora de que, para cada problema, as probabilidades de cruzamento e mutação devem ser adequadas a cada caso, com análises de sensibilidade que definam a ordem de grandeza que revele as melhores soluções otimizadas. Em termos de evolução de fitness em relação ao custo do consumo de energia elétrica, das estratégias ótimas propostas (CustoEE), os diferentes comportamentos estão apresentados na Figura 5.4.

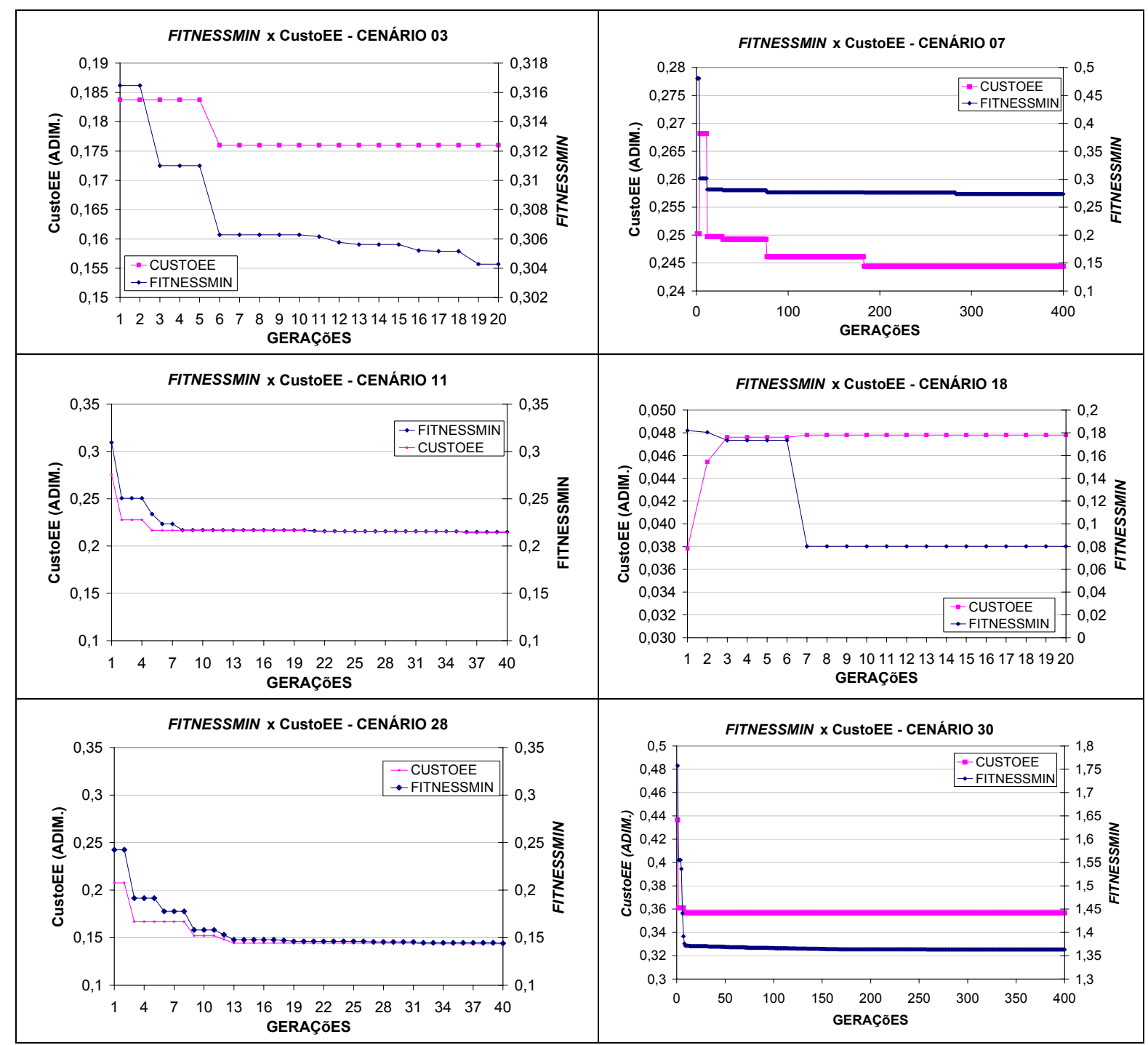

Figura 5.4 - Evolução da função de FitnessMin x CustoEE 
Observa-se na Figura 5.4, que ao longo da evolução, as soluções ótimas propostas pelos AG's são minimizadas em todas as gerações para os diversos cenários em análise. Os custos adimensionais do consumo de energia elétrica (CustoEE) também minimizam, mostrando que as estratégias de operação dos boosters escolhidas na solução ótima, são melhoradas em termos de poucos acionamentos.

Os cenários 03, 07 e 18 têm comportamentos diferentes tanto para a curva de CustoEE quanto para a curva de FitnessMin, independentemente da escala do gráfico, indicando que no valor total do fitness das soluções ótimas, também estão presentes os valores de violação das demais penalidades. Vale ressaltar que nestes cenários, a combinação de pesos é diferente, sendo o cenário 03 com tipo 2, o cenário 07 com tipo 3 e o cenário 18 usa tipo 1 , assim como os valores das PMUT também são diferentes $(0.2 \%, 10 \%$ e $10 \%)$.

Considerando os cenários 11, 28 e 30 individualmente, o comportamento das curvas de CustoEE e FitnessMin de cada cenário, são semelhantes a menos da escala, principalmente nos cenários 11 e 28, onde se nota a coincidência das duas curvas. Nestes três cenários, o tamanho da população é de 200, mas os pesos, as PCRUZ e PMUT são diferentes.

Com relação aos valores de custos de energia e potência utilizada, observa-se que nos cenários onde a dimensão da população oferece diversidade para busca ótima com menos mutações, tem-se os menores valores de INDICEPOT, ou seja, menos bombas acionadas. Os custos adimensionais são influenciados pela combinação de pesos aplicados. Nos cenários que fazem uso de pesos, seus custos adimensionais são maiores se a quantidade de bombas acionadas (mais potência consumida) é menor. No cenário 30 em que não se aplicam pesos, o valor de CustoEE é o seu valor de fato.

Explicando melhor. Pela equação 4.5, o CustoEE seria a unidade se o custo máximo (bombas operando 24h) fosse igual ao custo real (proposto pelo AG), ou seja operação máxima e a mais indesejada. Quando o custo real é menor que o custo máximo como se 
deseja, esta relação é um percentual do máximo. Quanto mais bombas acionadas, o custo real é mais próximo do custo máximo, obtém-se então da equação 4.5 , valores mais próximos de zero ( 1 menos este percentual) e quanto menos acionamentos menor o custo real e o CustoEE distancia-se de zero. Os valores apresentados na Tabela 5.4 ilustram bem essa variabilidade com e sem pesos. A comparação para os cenários em análise do comportamento das penalidades de violação do nível mínimo (PenaNivMin), de violação do nível máximo (PenaNivMax) e de nível inicial de operação maior que o nível final (PenaNivIF), é apresentada no gráfico da Figura 5.5.

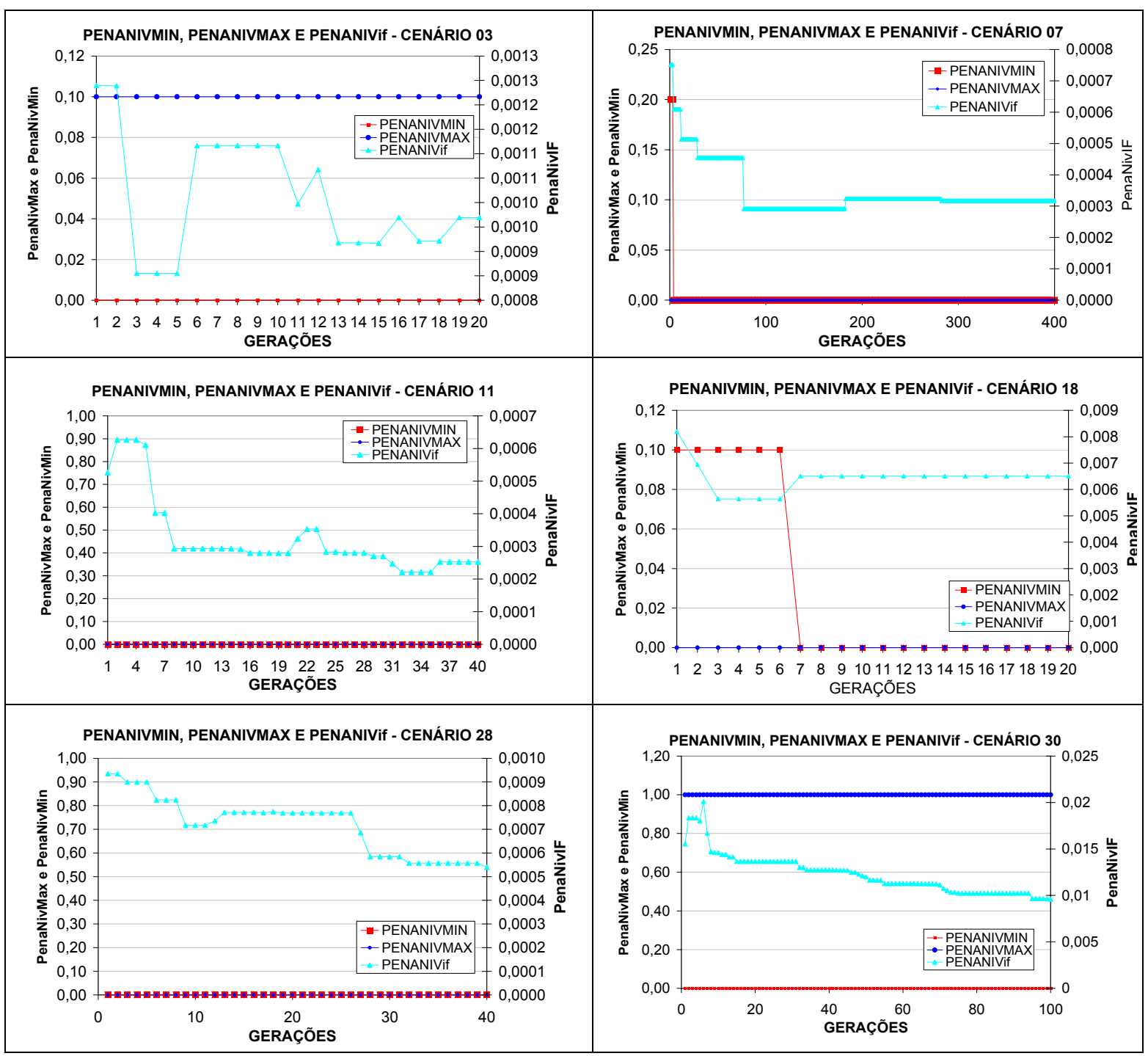

Figura 5.5 - Comportamento das penalidades PenaNivMax, PenaNivMin e PenaNivIF 
Como mostra a Figura 5.5, a penalidade de nível máximo só foi computada nos cenários 03 e 30, com pesos tipo 2 e sem pesos, respectivamente.

No código-fonte, a penalidade de violação ao limite alto é computada somente se o nível observado for maior ou igual a este limite de operação. No caso destes cenários, o nível observado foi somente igual ao limite alto e não maior. Como a penalidade de 0.10 imposta ao cenário 03 não é tão restritiva, o AG permitiu que, nas soluções escolhidas, este fato ocorresse. No caso do cenário 30, todas as penalidades e custos da função de fitness têm igual prioridade, e assim, tem mais valor para o AG a escolha pelo valor do fitness, e nesse caso, as soluções com esses valores tiveram menores fitness e foram escolhidas.

Com relação à penalidade de nível mínimo, esta foi violada apenas no início da evolução do cenário 18. Nos demais cenários, não houve violação em nenhuma das soluções propostas.

A penalidade de nível inicial maior que o final tem grande influência das características e limitações da rede em termos de topologia e a operação.

Os cenários 07 e 30, com mais gerações a desenvolver, têm processos de escolha de soluções com melhor finalização da operação, ou seja, os reservatórios finalizam a operação com níveis acima ou mais próximos do nível inicial.

Os cenários 11 e 20 com pesos aplicados de 0.05 e 0.10 , respectivamente, também minimizam suas violações, e os cenários 03 e 18 têm comportamento de minimização, mas com maior dificuldade em encontrar soluções com boa finalização na operação dos reservatórios. 


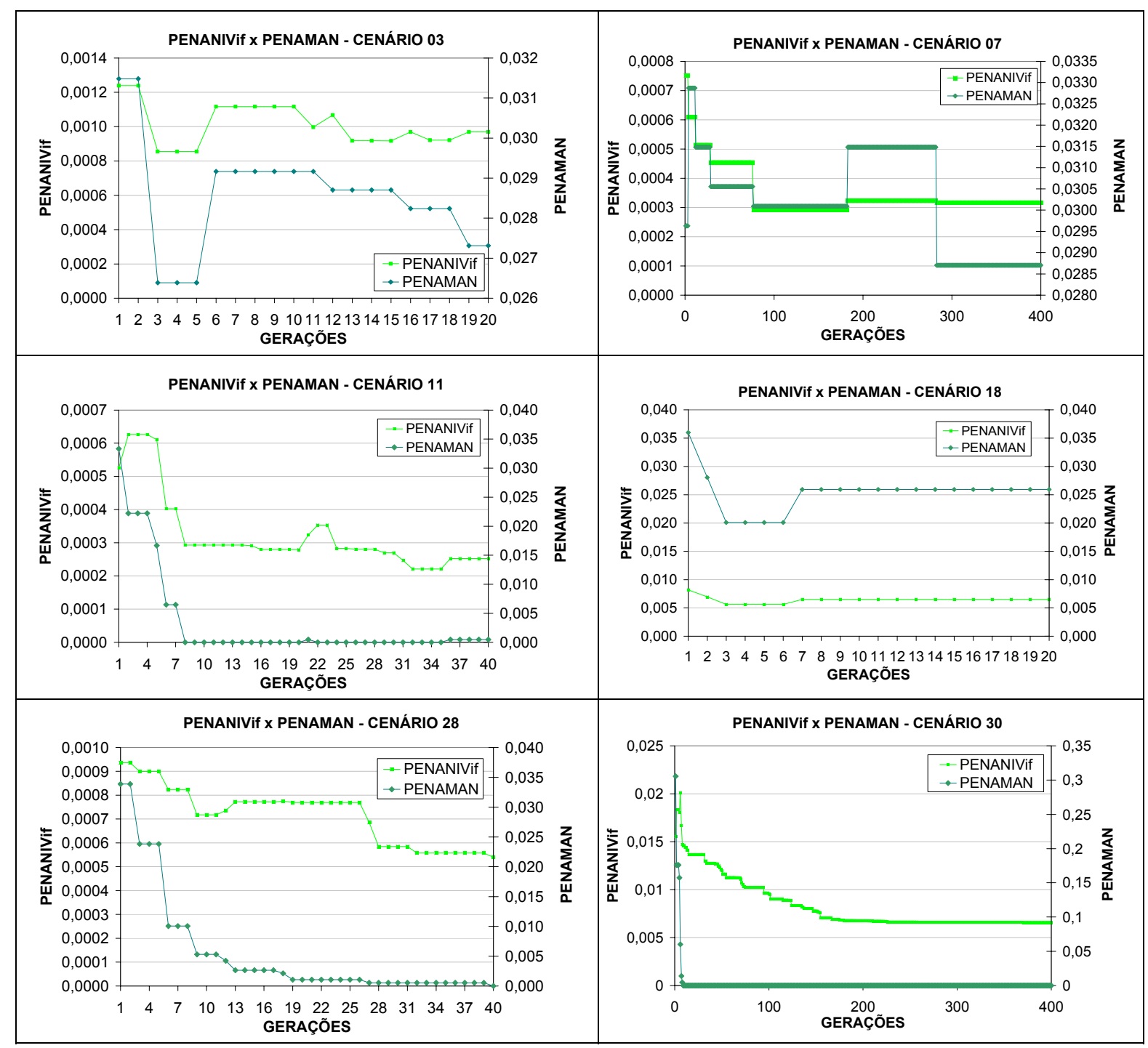

Figura 5.6 - Comportamento das penalidades PenaMan e PenaNivIF

No gráfico da Figura 5.6, nota-se que a quantidade de manobras nas válvulas influencia na maneira como os reservatórios finalizam sua operação. Observa-se que, quando o número de manobras é reduzido ou tende a redução, os reservatórios tendem a operar de forma mais acertada, e os níveis finais de operação tendem a voltar para o nível inicial de operação ou estar próximo dele, violando menos a penalidade PenaNivIF.

Os cenários 11, 28 e 30, são os que têm menores INDICEMANOBRA $(59 \%, 65 \%$ e 61\%) e também melhores evoluções das curvas de PenaMan, pois nas soluções ótimas da 
última geração, a quantidade de manobras de todas as 9 válvulas, atingiu o valor desejável de 27 manobras (3 manobras/dia) nos cenários 28 e 30, e ficou abaixo de 27 no cenário 11. Alguns reservatórios tiveram mais manobras em suas válvulas, decorrente das vazões aduzidas e outros tiveram menos acionamentos. Estes cenários têm em comum a população de 200 indivíduos e o que tem carga inicial mais favorável (cenário 30) é também o mais exigente em termos de PenaNivIF.

Os cenários 07 e 18, com PMUT de 10\% têm altos INDICEMANOBRA, com 102\% e $72 \%$, respectivamente, mostrando mais acionamentos nas válvulas que a regra do CCO. Apresenta um comportamento de "pulsos", mostrando que a perturbação introduzida pela mutação pode ser danosa, já que os pesos aplicados são de pouco impacto.

No cenário 03 , as duas curvas têm praticamente o mesmo comportamento a menos da escala, mas o peso de 0.10 nas duas penalidades permite que a solução ótima tenha INDICEMANOBRA de $95 \%$ mais manobras que o CCO.

\subsubsection{Estratégias ótimas de operação dos reservatórios}

Nos gráficos das Figuras 5.7 a 5.16, serão apresentadas as estratégias de operação otimizadas propostas pelos AG's para os reservatórios do SAM Leste. 


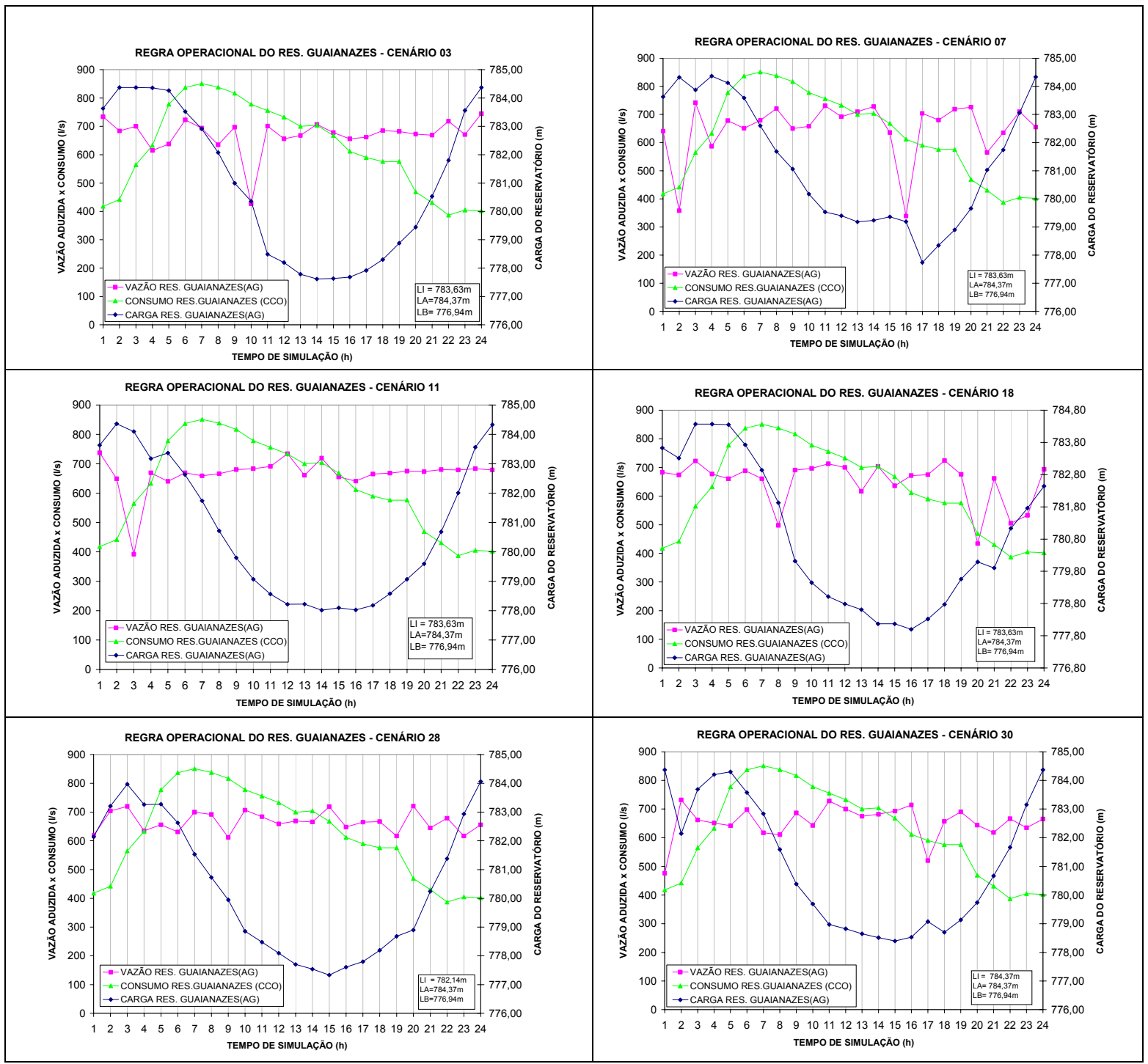

Figura 5.7 - Operação otimizada do Reservatório Guaianazes

Os gráficos da Figura 5.7 mostram que as estratégias de operação do Reservatório Guaianazes propostas pelo otimizador são boas para todos os cenários em análise. Observa-se que o reservatório não ultrapassa seus limites alto e baixo e só não têm uma operação mais estável nos cenários 7 e 18, causada pela PMUT de 10\%, que introduz maior perturbação aleatória nas soluções.

Os índices de oscilação de nível (ION) obtidos foram de 91\%, 89\%, 85\%, 86\%, 91\%, $80 \%$, nos cenários $03,07,11,18,28$ e 30 , respectivamente, com um ION médio de $87 \%$. Pela 
escala de desempenho proposta neste trabalho, o Reservatório Guaianazes tem boa oscilação de nível na média e em todos os cenários analisados, apesar de o cenário 07 ter a oscilação mais instável, pela ocorrência de manobras de maior amplitude na sua operação.

Os índices de oscilação de nível em relação à ocupação do reservatório (ION_OR) obtidos foram de $147 \%, 144 \%, 138 \%, 139 \%, 147 \%$ e $130 \%$, com valor médio de $141 \%$. Como os limites físicos operacionais do reservatório não foram violados durante a operação nos vários cenários, este índice remete a conclusão de que o reservatório oscilou mais do que deveria, mas dentro do que poderia fisicamente oscilar, atendendo a suas demandas sem condições extremas de operação.

Como o valor de $O R$ pela Tabela 5.1 para o Reservatório Guaianazes é de $61.76 \%$, o índice ION_OR indica que a oscilação média de $87 \%$ em relação à capacidade de atender as demandas mantendo a reservação de $61.76 \%$ é $141 \%$ ou seja, o reservatório oscila a mais $41 \%$.

As vazões aduzidas ao Reservatório Guaianazes, definidas como variáveis de decisão no modelo otimizador têm comportamento satisfatório, no que se refere ao número de manobras. Os índices de amplitude de vazões obtidos de $47 \%, 62 \%, 52 \%, 45 \%, 16 \%$ e 39\%, e valor médio de $44 \%$.

Os cenários 07 e 18 têm em comum a PMUT de 10\% e observam-se nas estratégias operacionais, dois momentos em que as vazões aduzidas propostas pelos AG's têm maior amplitude, provavelmente decorrente desta perturbação introduzida pela alta taxa de mutação dos cromossomos.

O cenário 28 tem uma estratégia muito boa, com o menor índice de amplitude de vazões de $16 \%$, proposta pelo otimizador, refletindo em uma operação estável e ideal. O tamanho da população de 200 cromossomos contribui para a diversidade no espaço de busca, dando maior possibilidade aos AG's de buscar por boas soluções. 
Os demais cenários, que têm menores PMUT, têm estratégias para as vazões aduzidas mais estáveis, a menos de alguns "pulsos" isolados, ao longo do período simulado.

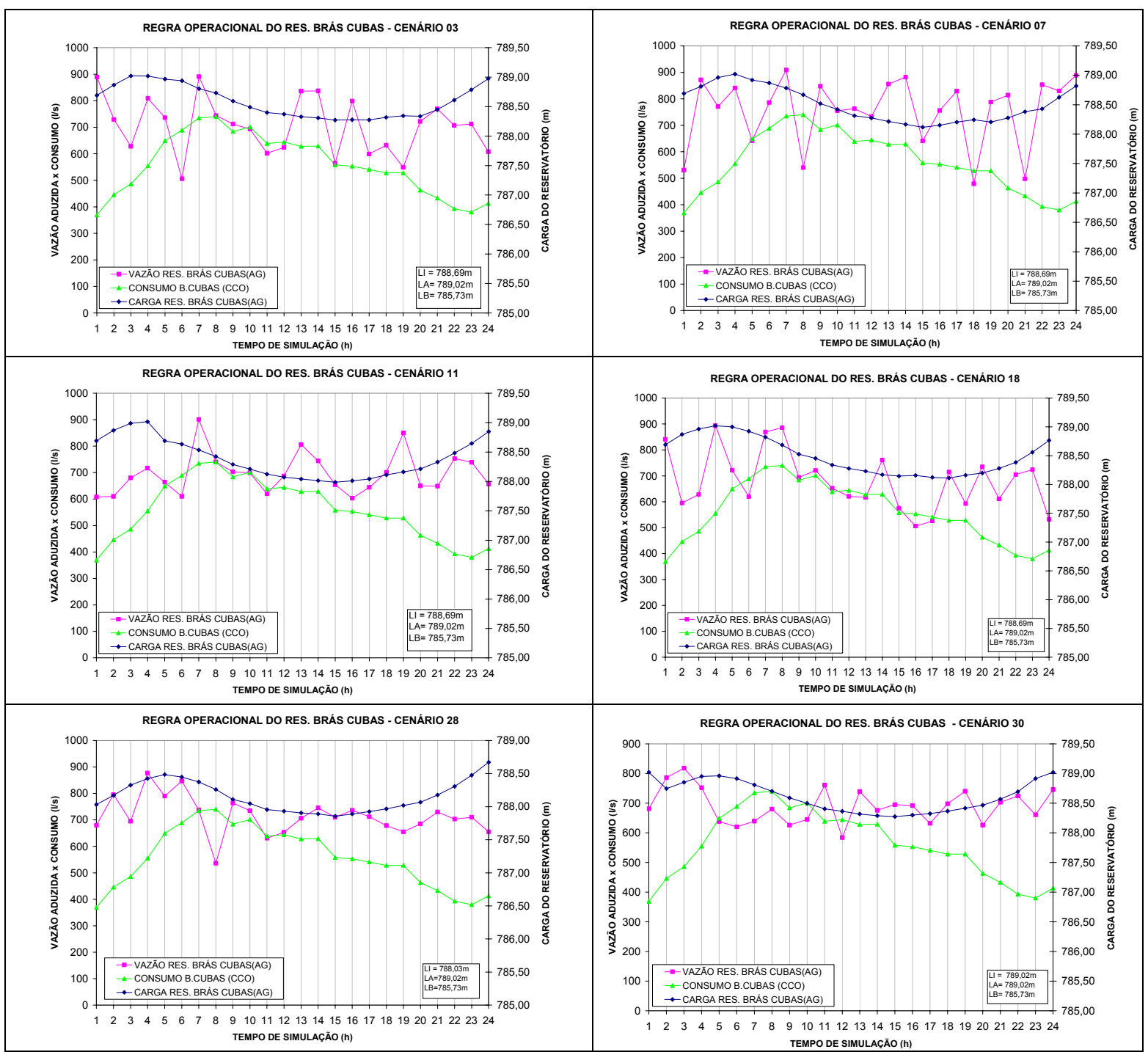

Figura 5.8 - Operação otimizada do Reservatório Brás Cubas

A Figura 5.8 mostra que o Reservatório Brás Cubas oscila pouco ao longo do período simulado de operação em todos os cenários. O índice de oscilação de nível ION foi de $23 \%$, $27 \%, 31 \%, 28 \%, 25 \%, 23 \%$, para os cenários $03,07,11,18,28$ e 30 respectivamente, com ION médio de $26 \%$. 
O cenário 11 é o que tem maior ION com $31 \%$, decorrente da sua estratégia de vazões de entrada que vinham com valores abaixo da curva de demanda, quando se iniciava o pico de consumo da rede.

Os que têm menores oscilações são os cenários 03,28 e 30 porque começam sua operação com vazões de entrada bem acima da curva de demanda.

Pela escala de desempenho proposta, o Reservatório Brás Cubas tem oscilação ruim.

Este reservatório tem um volume útil de $15.062 \mathrm{~m}^{3}$ e um volume necessário $5.770 \mathrm{~m}^{3}$, conforme Tabela 5.1. Se o ION é em média $26 \%$ do volume útil, o reservatório está utilizando $3.916 \mathrm{~m}^{3}$ para atender suas demandas, valor este que é menor que o volume necessário. Quer dizer que a dimensão do reservatório em termos de limites operacionais é mais que suficiente para sua operação, sem que sofra grandes oscilações de nível para atender as demandas.

Os índices ION_OR para o Reservatório Brás Cubas são de 59\%, 72\%, 82\%, 72\%, $65 \%, 59 \%$ respectivamente para os cenários em questão. O valor médio deste índice é $68 \%$, indicando que mesmo oscilando pouco segundo ION, esta variação de nível é considerada satisfatória, já que OR pela Tabela 5.1 é 38.31\% e ION_OR (ION/OR) médio de 68\% leva a uma oscilação de pouca utilização do reservatório.

Em todos os cenários analisados, o nível final de operação é bem próximo do inicial.

As vazões de entrada propostas pelos AG's do reservatório em análise não são de boa estratégia, apresentando muitos acionamentos das válvulas que corroboram para um índice de amplitude de vazões dos cenários $03,07,11,18,28$ e 30 de 55\%, 57\%, 43\%, 57\%, $48 \%, 34 \%$, respectivamente e uma média de $49 \%$.

Os cenários 11, 28 e 30, apresentam em estratégia melhor decorrente de sua população de 200 indivíduos e baixa PMUT, sendo o cenário 30 o de melhor estratégia e menor índice de amplitude. Os de pior índice e estratégia são os cenários 07 e 18, dada a perturbação aleatória introduzida pela PMUT $=10 \%$. 
Como o Reservatório Brás Cubas têm volume útil maior que o necessário, esperavase que o otimizador escolhesse uma estratégia de adução mais estável. A oscilação de vazão pode ser entendida como uma decisão operacional compensatória e auxiliar para os reservatórios restantes do SAM Leste.

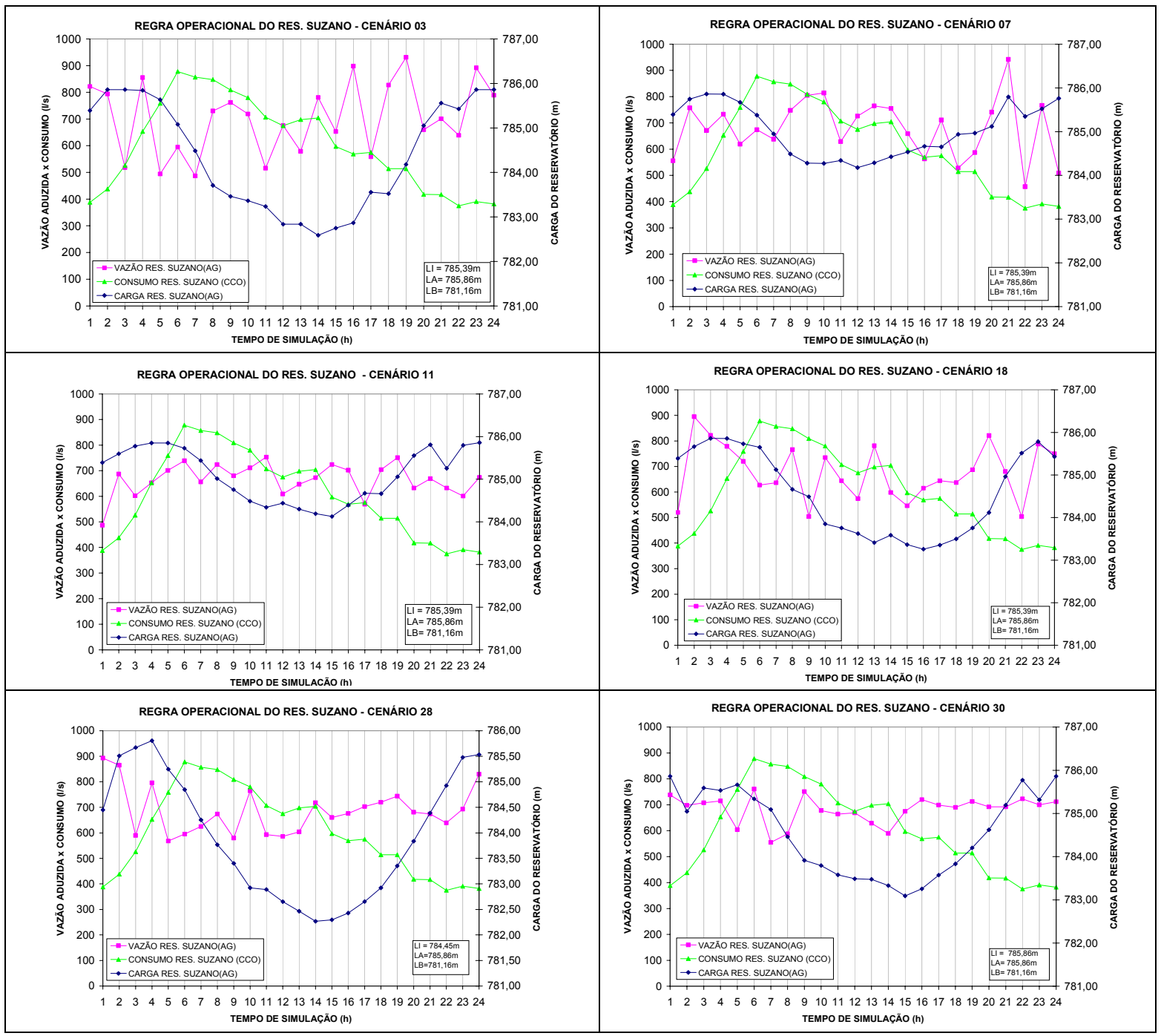

Figura 5.9 - Operação otimizada do Reservatório Suzano

A Figura 5.9 mostra a operação proposta pelo otimizador para o Reservatório Suzano. As oscilações de nível são representadas nos índices ION de 70\%, 36\%, 37\%, 55\%, $75 \%$ e $59 \%$ para os seis cenários em questão respectivamente, com um valor médio de ION de 
55\%. Utilizando a escala de desempenho proposta neste estudo, o desempenho do Reservatório Suzano é satisfatório. O reservatório também finaliza a operação com níveis bem próximos aos níveis iniciais propostos.

Os cenários 03 e 28, são os de maior oscilação de acordo com a Figura 5.9 e os valores de ION, tendo em comum a utilização dos pesos tipo 2, ou seja, peso 0.10 em PenaMan, cuja regra permite mais acionamentos nas válvulas e estratégias de vazões mais variáveis.

Os cenários com menor ION são o 07 e 11, e utilizam os pesos tipo 3, sendo o peso de 0.10 também aplicado a PenaMan. A diferença aqui, é que o cenário 07 tem população mais diversa de 200 indivíduos, e o cenário 11 tem 400 gerações para escolher melhor a solução ótima.

Os cenários 18 e 30 tem ION's satisfatórios pela escala de desempenho. Além de toda configuração de otimização ser diferente, o cenário 30 inicia a operação com reservatório $100 \%$ cheio, mas suas vazões de entrada começam com valores abaixo dos valores do cenário 18, que inicia a operação a $90 \%$ do nível máximo.

O valor de ION_OR de $177 \%, 91 \%, 94 \%, 141 \%, 191 \%$ e $150 \%$ mostra que o reservatório regulariza as demandas setoriais utilizando plenamente sua capacidade de armazenamento e de oscilação mais do que o desejado, mas dentro de seus limites operacionais, com valor médio de ION_OR de $141 \%$.

As estratégias das vazões de adução ao Reservatório Suzano propostas pelos AG's são de muitas manobras amplas para todos os cenários, ao longo das $24 \mathrm{~h}$ simuladas. O índice de amplitude de vazões de $63 \%, 71 \%, 40 \%, 58 \%, 47 \%$ e $30 \%$ para os seis cenários analisados, sendo o valor médio de $52 \%$.

O cenário 07 com PMUT de 10\% é o de maior índice pela manobra grande no final da operação, sendo razoável sua estratégia de adução. 
Os cenários 11 e 30 com menores PMUT são os de menor índice e melhor estratégia de adução proposta pelo otimizador.

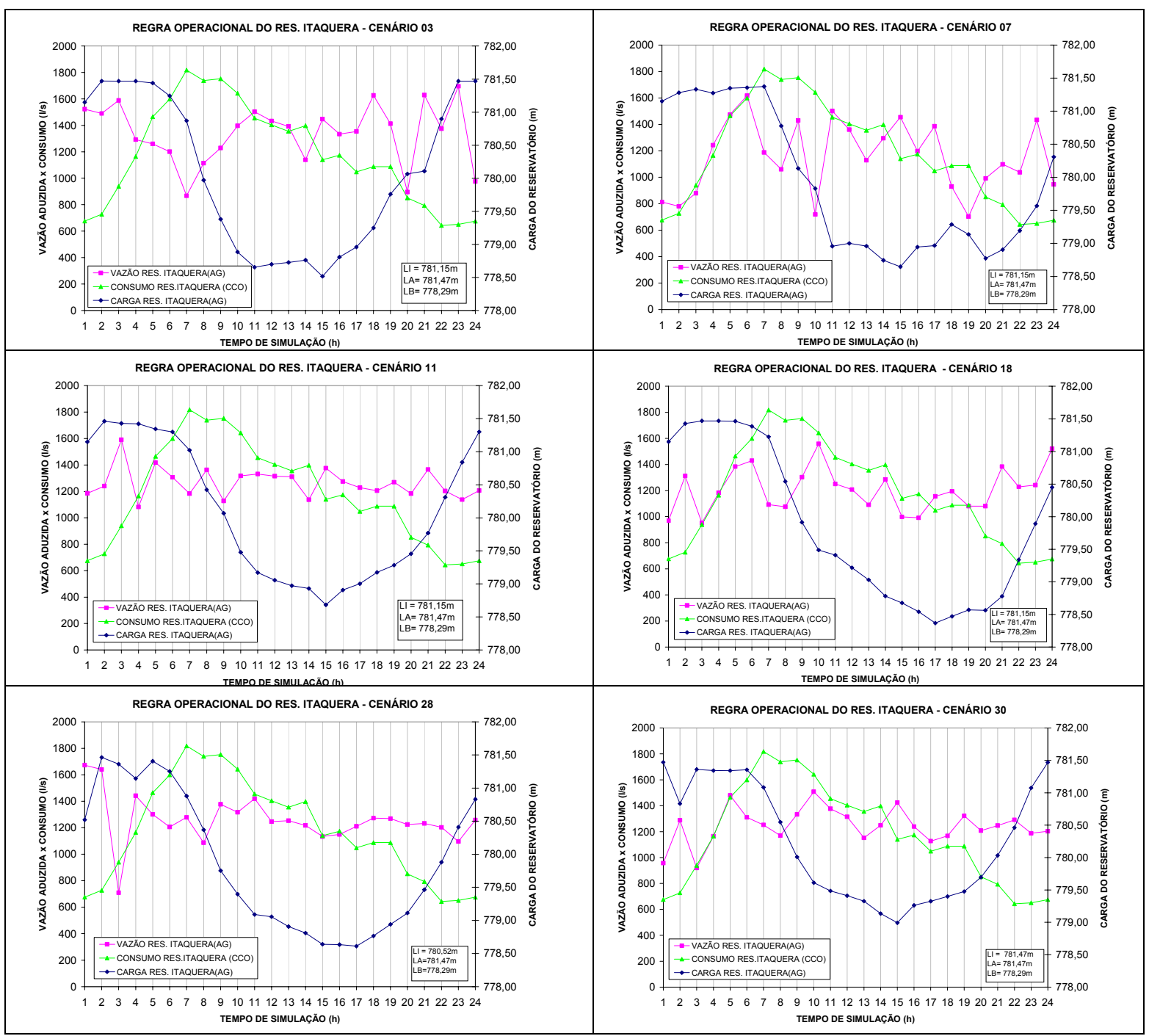

Figura 5.10 - Operação otimizada do Reservatório Itaquera

A Figura 5.10 mostra a operação proposta pelos AG's para o Reservatório Itaquera nos seis cenários analisados, sendo mais instável nos cenários 03 e 07 . Nos cenários 07 e 18, o nível final de operação viola PenaNivIF, pois o nível final é menor que o nível inicial. Nos demais cenários, a finalização da operação é sem violações. 
A maior oscilação de nível é conferida ao cenário 18 , ficando $8 \mathrm{~cm}$ acima do limite baixo operacional e atingindo o nível máximo definido. A menor oscilação é a do cenário 30, que é reduzida pela operação inicial favorável de 100\% do reservatório cheio.

A oscilação de nível mais instável é a do cenário 07, devido a sua estratégia de adução proposta pelo AG que não é boa, pela grande quantidade de manobras de grande amplitude.

Os índices de oscilação de nível obtidos nos seis cenários de otimização são de 93\%, $86 \%, 87 \%, 98 \%, 90 \%$ e $78 \%$, considerados bons, segundo a escala de desempenho aqui proposta, inclusive o valor médio de ION de $89 \%$, principalmente por não violarem seus limites alto e baixo em nenhum cenário.

Os índices ION_OR obtidos foram de 101\%, 93\%, 95\%, 106\%, 97\% e 84\%, sendo a média igual a $96 \%$. Para o volume útil de $14.857 \mathrm{~m}^{3}$ do Reservatório Itaquera, o reservatório necessita em média $14.262 \mathrm{~m}^{3}$ para atender suas demandas.

Em outras palavras, o reservatório oscila em sua amplitude entre o nível máximo e o mínimo de operação (limites alto e baixo) e tem capacidade de atender às suas demandas, Pode se dizer então, que o Reservatório Itaquera opera bem, segundo a escala de desempenho, utilizando toda sua capacidade de armazenamento, apesar de operar em condições extremas.

As vazões de entrada propostas pelos AG's para o Reservatório Itaquera apresentam índices de amplitude de vazões de $62 \%, 79 \%, 40 \%, 50 \%, 77 \%$ e $47 \%$ devido a grandes manobras principalmente nos cenários 03,07 e 28 . O valor médio do índice de amplitude obtido é de $59 \%$.

O cenário 07 tem índice de manobras (INDICEMANOBRA) de 202\%, o maior de todos os cenários. A baixa qualidade da estratégia de adução escolhida, decorre tanto da PMUT de $10 \%$ quanto do peso de 0.10 não ser tão restritivo, aplicado à PenaMan, peso este idêntico aos dos cenários 03 e 28 . 
A melhor estratégia de vazões de adução proposta pelos AG's é a do cenário 11, que tem o menor índice de amplitude de vazões, cenário que fornece ao modelo otimizador bom espaço de busca à baixa PMUT, mesmo que também tenha o peso de 0.10 aplicado à PenaMan.

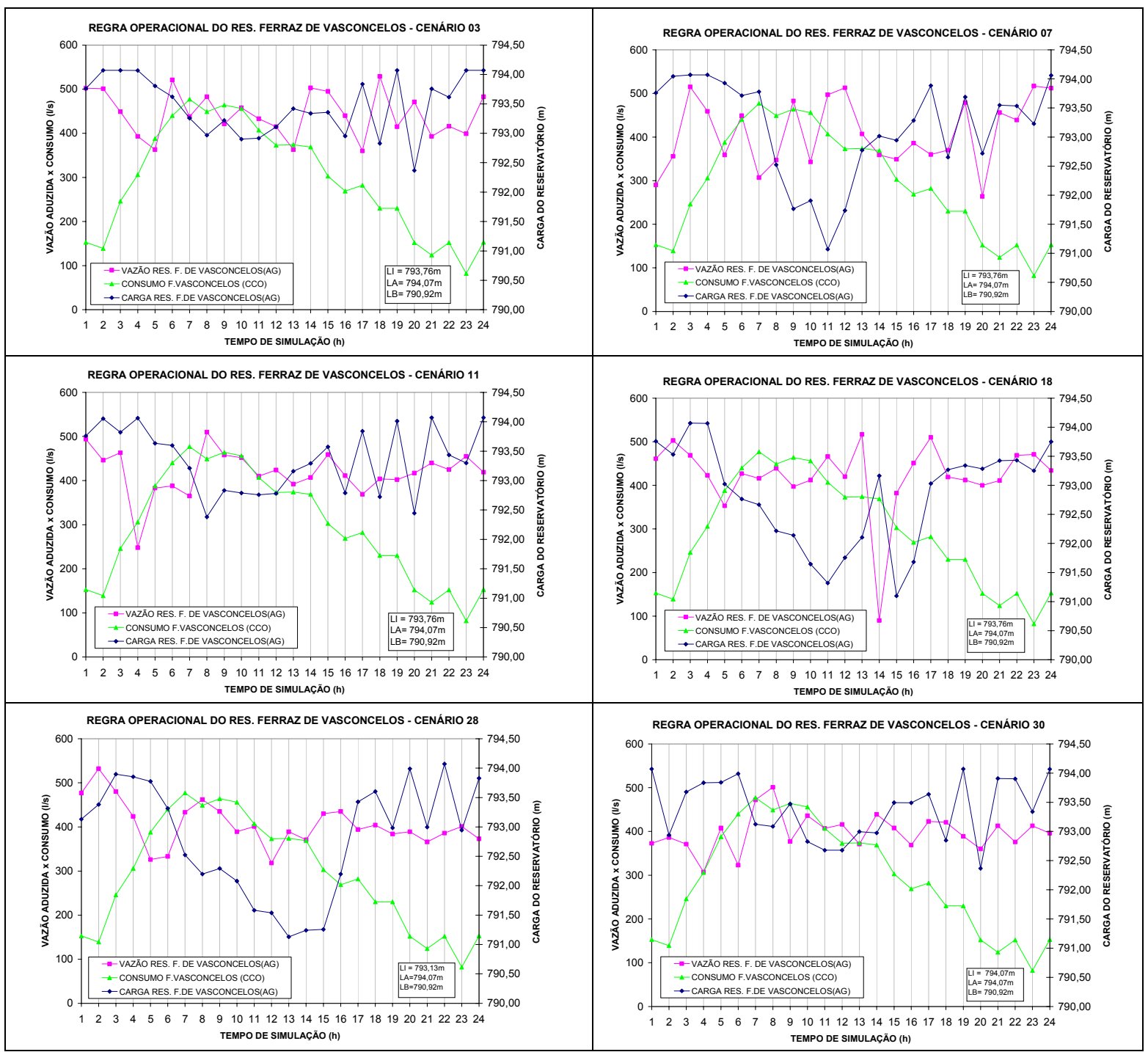

Figura 5.11 - Operação otimizada do Reservatório Ferraz de Vasconcelos.

A Figura 5.11 ilustra a operação do Reservatório Ferraz de Vasconcelos, segundo a regra fornecida pelo modelo otimizador para os cenários $03,07,11,18,28$ e 30. 
Observa-se, no gráfico em questão, que a oscilação de nível deste reservatório é variada nos diversos cenários, com ION de 54\%, 95\%, 54\%, 94\%, 93\%, 54\%. O valor médio de ION foi de $74 \%$, sendo ainda satisfatório pela escala proposta. Observa-se uma constância de $\mathrm{ION}=54 \%$ nos cenários 03,11 e 30 , cujas PMUT de $0.2 \%, 0.5 \%$ e $0.2 \%$ são muito próximas levando a operações próximas também.

Por outro lado, nos cenários 07,18 e 28 com maiores probabilidades de mutação, o AG propõe operações em que o Reservatório Ferraz de Vasconcelos foi mais solicitado e oscilou mais.

Segundo o índice que relaciona o ION com a ocupação dos reservatórios (ION_OR), os valores obtidos nestes seis cenários foram de $18 \%, 32 \%, 18 \%, 32 \%, 32 \%, 18 \%$ respectivamente, sendo o valor médio deste índice de 25\%. Como este reservatório tem pequena capacidade, os cenários com baixo $I O N \_O R$ são os que exploram pouco a capacidade do Reservatório Ferraz de Vasconcelos.

Nos cenários 07,18 e 28, que tem exatamente o dobro do ION_OR dos demais cenários, o modelo propõe estratégias operacionais que utilizam mais plenamente a pequena capacidade de armazenamento e que atende às demandas locais, já que não viola os limites operacionais alto e baixo. Apesar de toda a instabilidade da oscilação do reservatório, em nenhum dos seis cenários, o nível final de operação está abaixo do nível inicial de operação, não violando portanto, a penalidade PenaNivIF.

Com relação às estratégias de adução ao Reservatório Ferraz de Vasconcelos, os diversos cenários de otimização apresentados pela Figura 5.11, ilustram a dificuldade do modelo em gerar estratégias de poucas manobras.

Os índices de amplitude de vazão dos cenários 03, 07, 11, 18, 28 e 30 são de 38\%, $62 \%, 63 \%, 101 \%, 53 \%, 49 \%$, respectivamente. Destes, o que apresenta menor índice e, portanto, melhor estratégia de adução é o cenário 03 e o cenário com maior valor é o cenário 
18, devido à manobra entre a $13 .^{\mathrm{a}}$ e a $16 .^{\mathrm{a}}$ hora de simulação, o que não implica que a estratégia seja totalmente de má qualidade. Como neste cenário a PMUT utilizada é de $10 \%$, essas manobras atípicas são originadas de mutação.

Os cenários 28 e 30 também têm boas estratégias de vazões de entrada, que são mais estáveis devido às possibilidades de busca mais ampla com a população de 200 indivíduos.

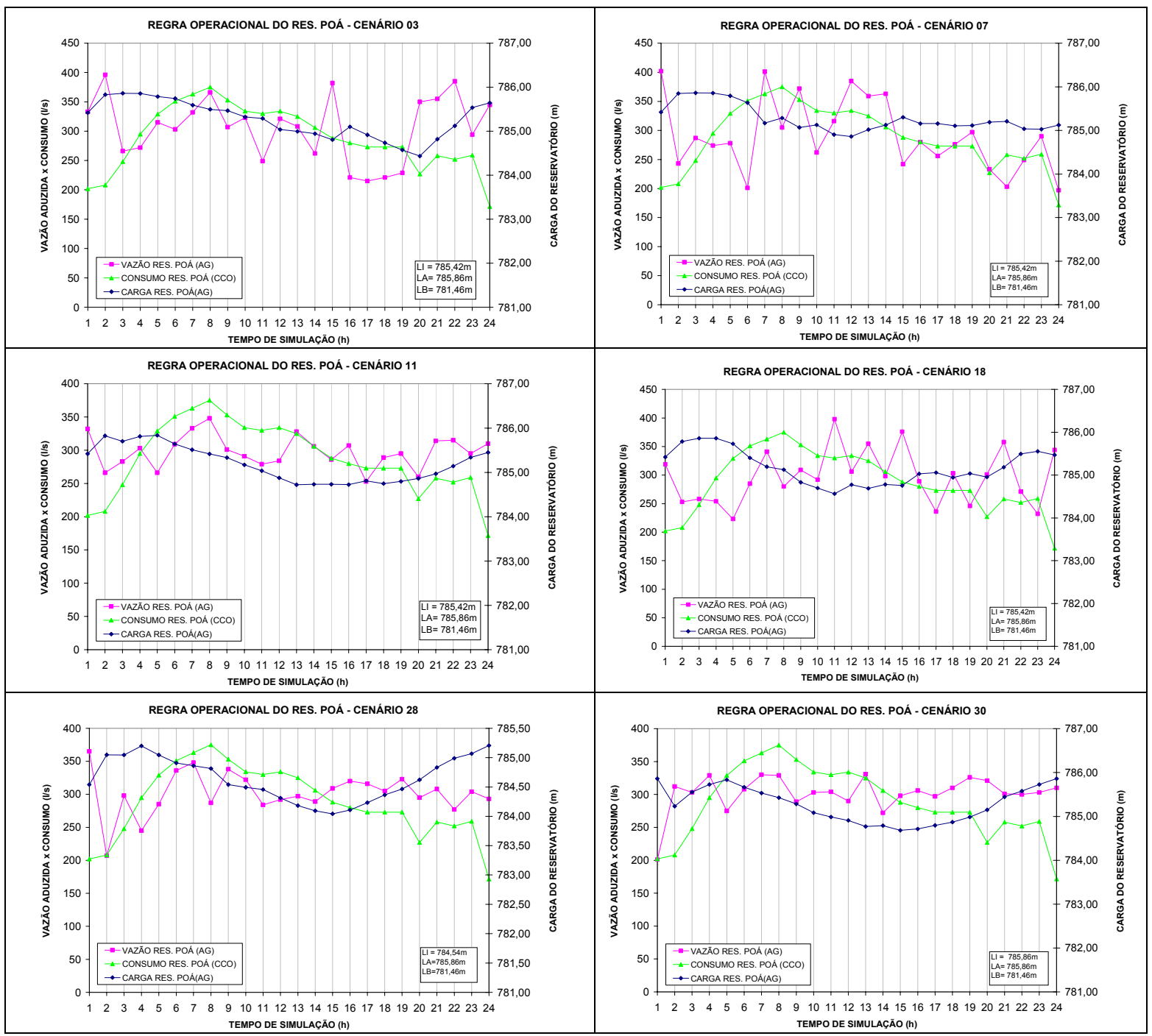

Figura 5.12 - Operação otimizada do Reservatório Poá. 
Na Figura 5.12, observa-se que o Reservatório Poá tem pequena oscilação de nível nos cenários $03,07,11,18,28$ e 30, representada pelos ION's de 32\%, 23\%, 25\%, 29\%, 26\% e $27 \%$, respectivamente e valor médio de $27 \%$.

$\mathrm{Na}$ escala de desempenho, estes valores de cada cenário e o médio inclusive, estariam colocados em um patamar de desempenho ruim, já que o Reservatório Poá realmente pouco oscila. O cenário 07 registra a menor oscilação de nível e o cenário 03, a maior oscilação, já que nestes cenários a variabilidade das vazões de entrada leva a esta oscilação, maior ou menor.

Os índices ION_OR obtidos foram de 39\%, 28\%,31\%,36\%,32\% e 33\% para os seis cenários. O valor médio obtido foi de 33\% significando que apenas $33 \%$ do volume útil do reservatório são utilizados em média, ou seja, o reservatório não deve oscilar muito realmente.

A operação do reservatório não finaliza bem somente no cenário 07 , que tem nível final abaixo do inicial, violando PenaNivIF.

Os índices de amplitude de vazão obtidos foram de 59\%, 71\%, 32\%, 59\%, 52\% e 43\%, com valor do índice de amplitude média de 53\%. Os cenários 03, 07 e 18 são os que apresentam as piores estratégias de adução com maiores manobras, principalmente o cenário 07. Eles têm em comum a pequena população com poucas opções de busca e no caso dos cenários 07 e 18, a PMUT de 10\%. Os cenários 11, 28 e 30 são os que têm melhores estratégia de vazões aduzidas, sendo o cenário 11 o de menor índice e o 30 o cenário de melhor evolução. 


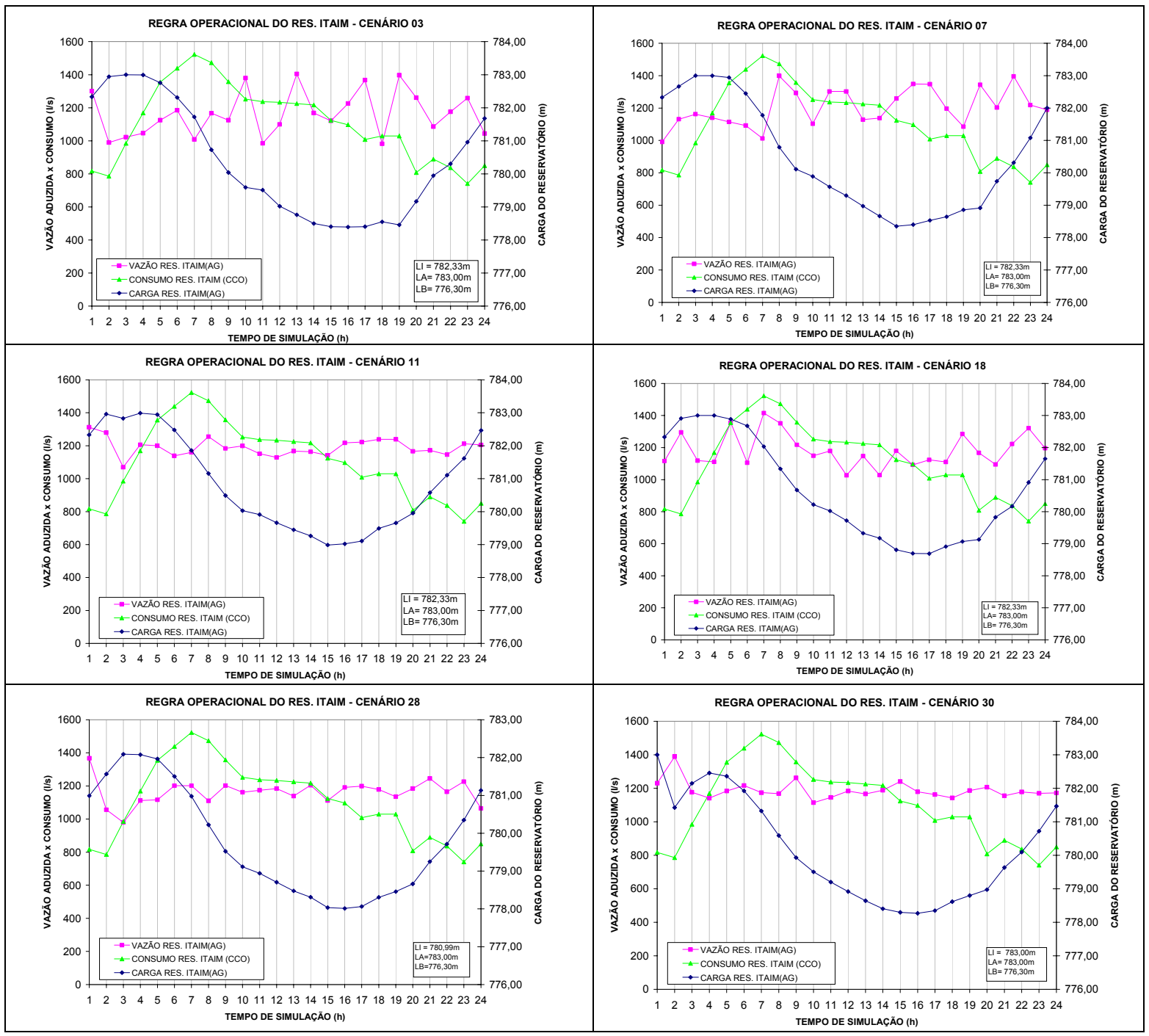

Figura 5.13 - Operação otimizada do Reservatório Itaim

A Figura 5.13 mostra que o modelo de otimização propôs boas estratégias de operação para Reservatório Itaim, nos seis cenários em análise.

As oscilações de nível representadas pelo índice ION foram de 69\%, 69\%, 60\%, $64 \%, 61 \%$ e $71 \%$ para os cenários $03,07,11,18,28$ e 30 , respectivamente. $\mathrm{O}$ valor médio deste índice foi de $66 \%$. De acordo com a escala de desempenho, o Reservatório Itaim tem desempenho satisfatório em todos os cenários analisados, sendo o melhor o cenário 30 e o de menor oscilação, o cenário 11 . 
Os índices ION_OR obtidos nos respectivos cenários foram $62 \%, 63 \%, 54 \%, 58 \%$, $55 \%$ e $64 \%$, sendo que o valor médio é de 54\%. Isto é, o Reservatório Itaim deveria oscilar consideravelmente, dentro de seus limites alto e baixo de operação, utilizando em média 54\% do volume útil para regularizar as demandas do seu setor da rede. O cenário 30 é o de melhor índice e o 11, o de menor oscilação. Os cenários 03, 07, 18 e 30 violam a penalidade PenaNivIF por finalizarem a operação com nível final abaixo do nível inicial.

As estratégias de vazão de entrada propostas para os seis cenários fornecem índices de amplitude de vazões $36 \%, 34 \%, 20 \%, 33 \%, 33 \%$ e $23 \%$. O valor médio para este índice é de $30 \%$. O melhor valor é o do cenário 11 . Os cenários 28 e 30 também têm boas estratégias de adução e têm em comum com o cenário 11, população de bom tamanho e diversidade para a busca de soluções ótimas.

Os cenários de maior índice de amplitude com muitas manobras são os cenários 03 e 07, que têm em comum pequenas populações sem muitas opções e soluções no espaço de busca, além da PMUT de 10\% do cenário 07. 


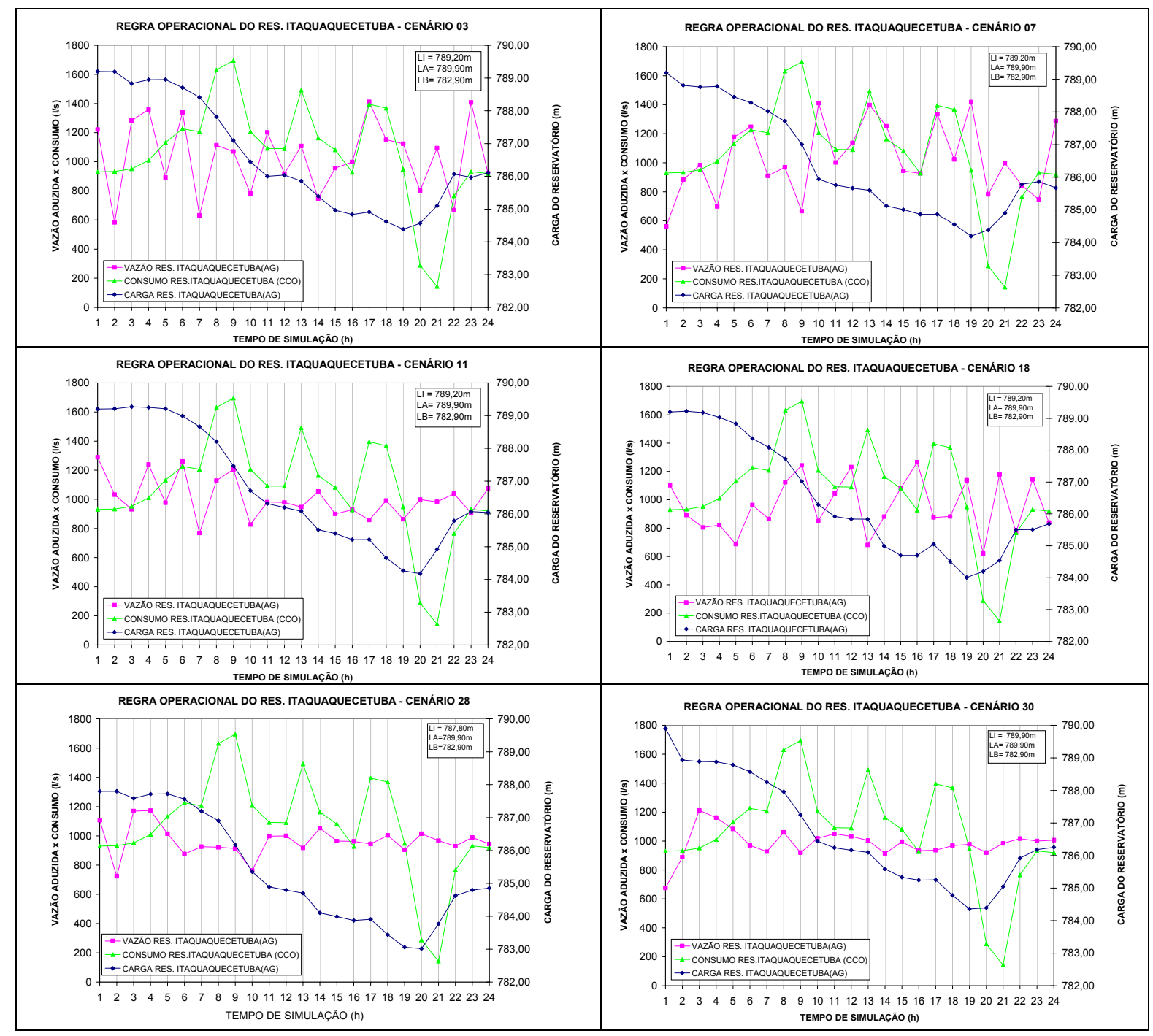

Figura 5.14 - Operação otimizada do Reservatório Itaquaquecetuba

A Figura 5.14 mostra que a operação proposta pelos AG's para o Reservatório Itaquaquecetuba para os seis cenários analisados poderia ser melhor, já que em nenhum dos seis cenários apresentados, o nível final de operação fica próximo do nível inicial de operação, violando assim PenaNivIF. Todas as combinações de pesos, inclusive a tipo 1 que aplica um peso 0.60 à PenaNivIF, não foram suficientes para definir a melhor operação.

No caso do Reservatório Itaquaquecetuba, a política de penalidade poderia ser outra, por exemplo, utilizando uma função de penalidade que fosse mais restritiva com o decorrer 
das gerações, como sugerido por Savic et al. (1997) ou a metodologia sugerida por Deb (2000) de funções de penalidade sem qualquer parâmetro de penalidade.

Os índices de oscilação de nível (ION) para os cenários 03, 07, 11, 18, 28 e 30 são na seqüência, $69 \%, 71 \%, 73 \%, 75 \%, 68 \%$ e $79 \%$ com média de $71 \%$.

Estes valores de ION são de desempenho satisfatório, pela escala de desempenho apresentada neste trabalho, indicando que em média o reservatório necessita de $71 \%$ do volume útil para regularização de demandas. O cenário de maior oscilação é o cenário 30 e o de menor oscilação é o cenário 28 .

No cenário 30, a operação inicial é de $100 \%$ do reservatório cheio e por isso tem a maior oscilação de nível, já que o nível mínimo observado é de pouco mais de $1.0 \mathrm{~m}$ acima do limite baixo. No caso do cenário 28 , a carga inicial de operação é de $70 \%$ do nível máximo e assim a operação é mais restritiva pela redução de volume para atender as demandas.

Considerando o volume necessário do Reservatório Itaquaquecetuba e a capacidade de regularizar suas demandas, os índices $I O N \_O R$ obtidos foram de 157\%, 163\%, 165\%, $170 \%, 155 \%$ e $180 \%$ e média de $165 \%$, para os cenários em questão.

Como o reservatório não viola seus limites alto e baixo operacionais, e tem volume útil de $12.301 \mathrm{~m}^{3}$ e volume necessário de $5.406 \mathrm{~m}^{3}$, o valor máximo de $I O N \_O R$ obtido de 180\% para o cenário 30 com OR da Tabela 5.1 de $43.95 \%$, indica que foram utilizados $80 \%$ a mais do previsto para oscilação de nível. Fazendo as contas, o valor de $79 \%$ de ION sobre os 43.95\% de $O R$, mostra que foram utilizados $79 \%$ do volume útil ou $80 \%$ do volume necessário do Reservatório Itaquaquecetuba.

Na tentativa de estabelecer uma operação otimizada, o AG considera toda a rede e dado o volume considerável do Reservatório Itaquaquecetuba, ele acaba por auxiliar os demais reservatórios do SAM Leste, que têm uma capacidade menor. 
As estratégias de adução dos diferentes cenários propostas pelo AG são de muitas manobras, com valores dos índices de amplitude de vazão de $80 \%, 84 \%, 52 \%, 67 \%, 46 \%$ e $54 \%$, sendo a média de $64 \%$. O cenário com melhor estratégia é o cenário 28 que tem e, seguido dos cenários 11 e 30, todos com população de 200 indivíduos e baixas PMUT de 1\%, $0.5 \%$ e $0.2 \%$, respectivamente. O de pior estratégia de adução é o cenário 07 , com alta PMUT de $10 \%$. Entre o melhor cenário e o pior, o peso de 0.10 imposto à PenaMan teve menos influência que os parâmetros de população e probabilidade de mutação dos AG's, na escolha da melhor estratégia de adução que influencia na oscilação do reservatório.

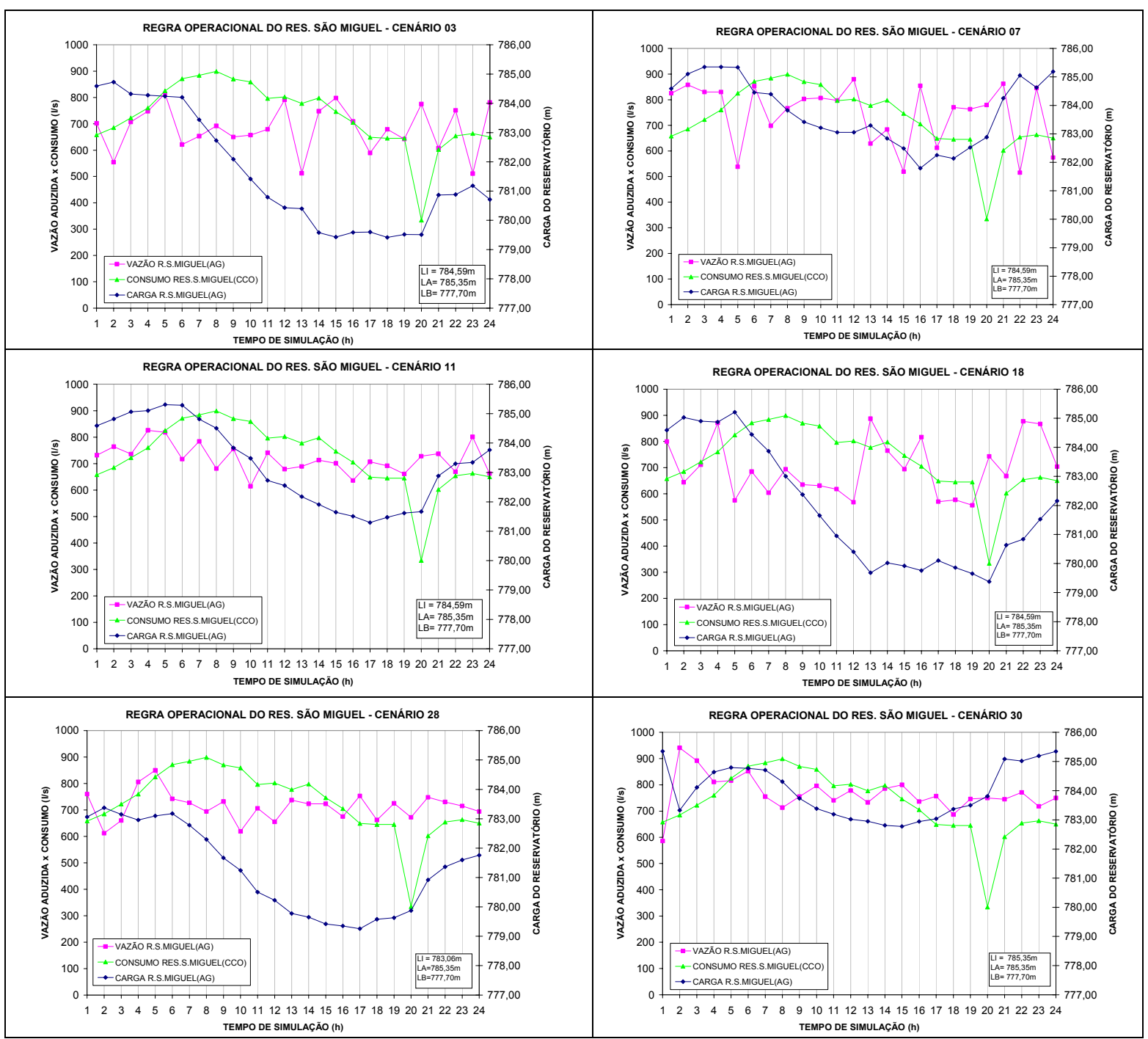

Figura 5.15 - Operação otimizada do Reservatório São Miguel 
A Figura 5.15 mostra que a operação do Reservatório São Miguel, fornecida pelos AG's para os seis cenários analisados é bem diversificada. Os níveis finais de operação dos cenários $03,11,18$ e 28 são menores que os níveis iniciais e, portanto, violam a penalidade PenaNivIF.

Mesmo se colocando peso de 0.60 (combinação tipo 1) no cenário 28 , observa-se que o peso isoladamente, não tem grande influência na escolha da solução, mas sim a estratégia de pesos como um todo. Observa-se melhor esse fato no cenário 30, em que não há a aplicação de pesos e no cenário 07 , onde o peso aplicado é 0.05 . Em outras palavras, vale o contexto da estratégia, pois o AG escolhe pelo valor do fitness que é o resultado da estratégia e não isoladamente do peso.

Os índices de oscilação de nível (ION) obtidos foram 69\%, 47\%, 52\%, 76\%, 54\% e $34 \%$ e o valor médio foi de 55\%. O cenário com menor oscilação foi o cenário 30 e o de maior oscilação foi o cenário 18. Pela escala de desempenho, o Reservatório São Miguel têm desempenho de razoável a satisfatório, mas satisfatório em média, utilizando para atender suas demandas, $55 \%$ do volume útil.

Os índices ION_OR obtidos nas seis simulações foram de 161\%, 108\%, 121\%, $176 \%, 125 \%$ e $78 \%$ e o valor médio foi de $128 \%$, ou seja, o reservatório oscila com segurança dentro dos limites operacionais e a mais do que era previsto, necessitando do acréscimo de $28 \%$ ao volume necessário para atender suas demandas, já que $O R$ pela Tabela 5.1 é de $43.21 \%$.

Os índices de amplitude de vazões de entrada obtidos pelas estratégias dos cenários $03,07,11,18,28$ e 30 foram de $44 \%, 49 \%, 30 \%, 47 \%, 33 \%$ e $46 \%$, respectivamente e valor médio de $42 \%$.

O cenário 11 foi o de estratégia com manobras mais estáveis, seguido pelos cenários 28 e 03 , já que no cenário 30 ocorre uma manobra de grande amplitude no início da operação. 
O cenário 07 e 18 têm estratégias muito instáveis, já que a perturbação aleatória introduzida pela PMUT de 10\% influenciou na decisão operacional das vazões.

Com base na operação apresentada para todos os reservatórios do SAM Leste nos cenários analisados, a estratégia de pesos aplicada ajuda o AG de forma mais secundária na escolha da regra ótima de operação, sendo que os parâmetros de população e probabilidade de mutação, são as condições mais impactantes e decisivas no processo de otimização dos AG's.

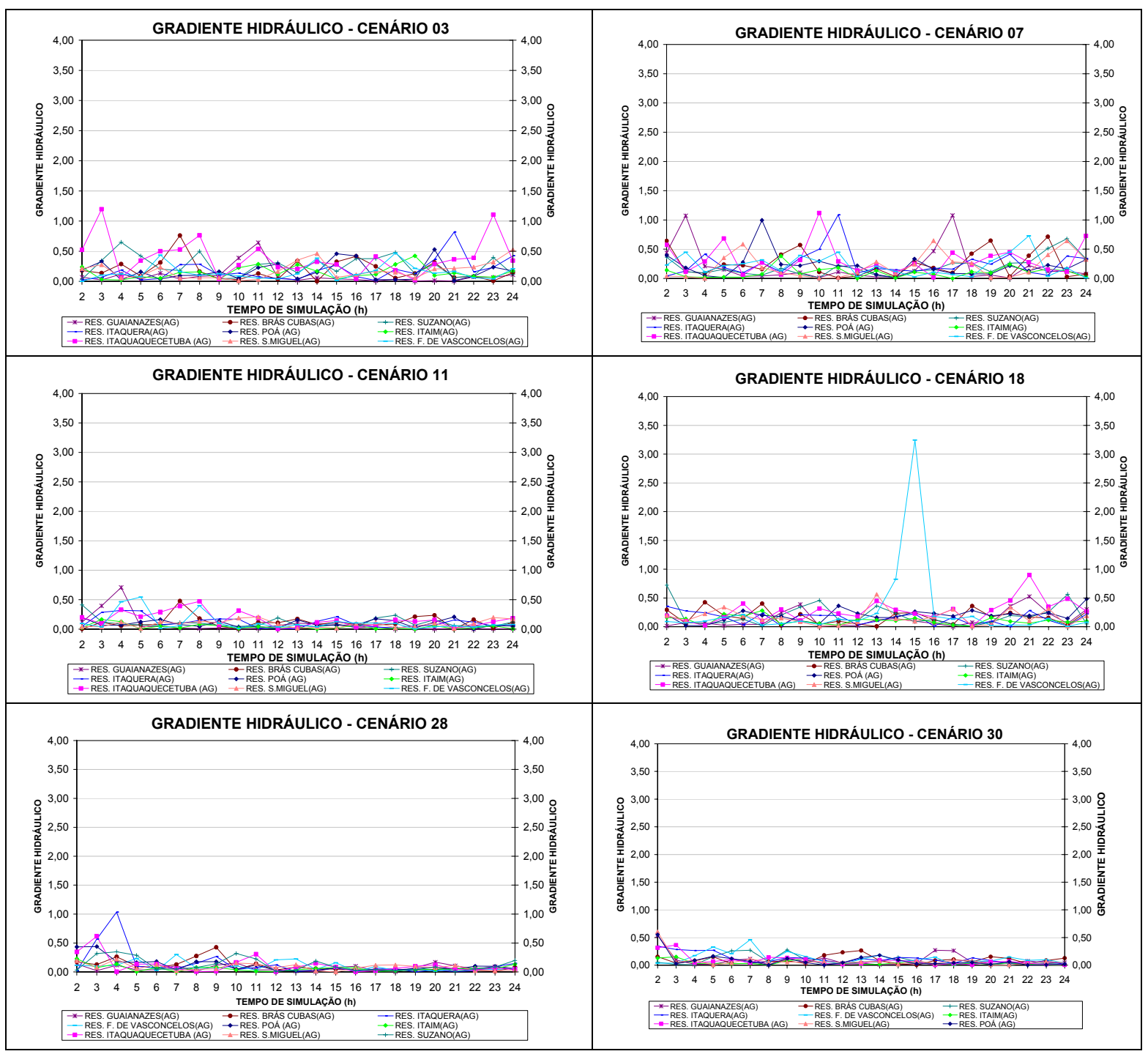

Figura 5.16 - Gradientes hidráulicos horários dos cenários de otimização. 
A Figura 5.16 ilustra o comportamento dos gradientes hidráulicos das vazões de entrada dos reservatórios do SAM Leste, nos cenários 03, 07, 11, 18, 28 e 30. Observa-se que os cenários 11 e 30 são os de menores gradientes, refletindo as estratégias de adução sem grandes manobras. As estratégias de vazão de adução dos Reservatórios Itaquera, Ferraz de Vasconcelos e Itaquaquecetuba são os de maiores variações de gradiente, conforme os cenários, 03, 07, 18 e 28.

5.3.2. Esquemas otimizados de operação dos boosters e estações elevatórias

Os esquemas de operação das variáveis de decisão pertinentes às bombas serão apresentados da Figura 5.17 a 5.21. 


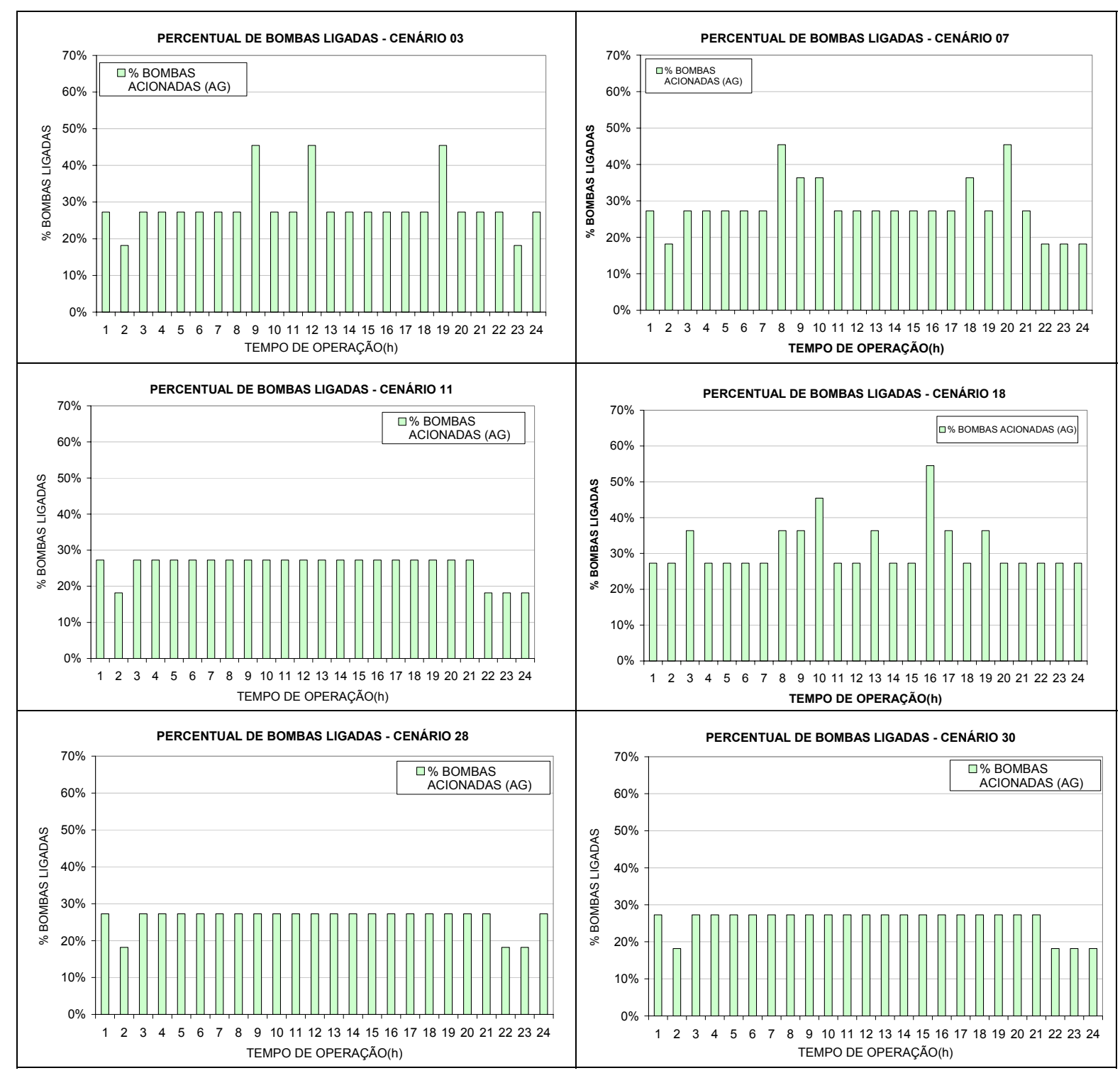

Figura 5.17 - Percentual de operação dos boosters e estações elevatórias dos cenários otimizados

A Figura 5.17 mostra o percentual de grupos moto-bombas em operação no período simulado, considerando o total de 11 equipamentos do SAM Leste, para os cenários de otimização $03,07,11,18,28$ e 30 , sendo este percentual de $63 \%, 62 \%, 56 \%, 69 \%, 57 \%$ e $56 \%$ respectivamente. Os cenários com menor quantidade de equipamentos acionados são o cenário 11 e 30 e o que mais aciona as bombas é o cenário 18. 
Os cenários 11 e 30 mantêm um padrão estável de operação, tanto no horário de ponta, com $7 \%$ de equipamentos em operação e $49 \%$ no horário fora de ponta, totalizando $56 \%$ para ambos os cenários.

Isso implica em $2.430 \mathrm{~kW}(13 \%)$ de potência consumida no horário de ponta (maior consumo e tarifa mais cara) e $16.126 \mathrm{~kW}(88 \%)$ no horário de fora ponta, num total diário de 18.556kW (18.6MW). A potência consumida no horário de ponta é da proporção de 1:6 em relação ao horário fora de ponta.

Os consumos de energia elétrica nos horários de ponta ( $3 \mathrm{~h}$ de operação) e fora de ponta (20h de operação em média), nestes cenários, foram de $810 \mathrm{~kW} . \mathrm{h}$ e 806kW.h, respectivamente. Proporcionalmente o consumo no horário de fora de ponta em relação ao consumo no horário de ponta é aproximadamente 1:1.

Com relação ao cenário 18, que apresenta esquema operacional com maior número de grupos moto-bombas ligados, os percentuais de operação são de $8 \%$ e $60 \%$. Estes percentuais implicam em $2.798 \mathrm{~kW}(12 \%)$ e $20.838 \mathrm{~kW}(88 \%)$ de potência consumida nos horários de ponta e fora de ponta, respectivamente, totalizando $23.636 \mathrm{~kW}(23.6 \mathrm{MW})$. A potência consumida no horário de ponta é da proporção de 1:7 em relação ao horário fora de ponta.

A energia elétrica consumida neste cenário foi de $1.119 \mathrm{~kW} . \mathrm{h}$ no horário de ponta e de $2.033 \mathrm{~kW}$.h no horário fora de ponta, considerando um tempo médio de operação nestes horários de $2.5 \mathrm{~h}$ e $10.25 \mathrm{~h}$, respectivamente. A proporção de consumo neste cenário é de 1:1.8 entre os horários de ponta e fora de ponta.

$\mathrm{Na}$ regra praticada pelo $\mathrm{CCO}$, estes valores percentuais de equipamentos em operação são de $10 \%$ e $58 \%$. As potências consumidas pelos equipamentos são de $4.419 \mathrm{~kW}$ $(17 \%)$ e $21.800 \mathrm{~kW}(83 \%)$, nos horários de ponta e fora de ponta respectivamente, totalizando 
26.219kW (26.2MW). A potência consumida no horário de ponta é da proporção de 1:5 em relação ao horário fora de ponta.

Os consumos de energia elétrica na regra do CCO nos horários de ponta e fora de ponta foram de $1.473 \mathrm{~kW}$.h e $1.246 \mathrm{~kW} . \mathrm{h}$, respectivamente. A proporção entre os consumos do horário fora de ponta em relação ao de ponta é de 1:1.18.

Tanto na operação dos cenários 11 e 30, que têm menores acionamentos, quanto no cenário 18, que é o mais dispendioso, os esquemas operacionais fornecidos pelo modelo otimizador são mais econômicos, principalmente no horário de tarifa mais elevada.

Comparando a regra do $\mathrm{CCO}$, com a operação de maior potência consumida proposta pelos AG's, que é de $23.6 \mathrm{MW}$ do cenário 18 , obtém-se uma redução de $10 \%$ na potência consumida, sendo a regra dos AG's uma proporção de 1:1.1 da regra do CCO. Em valores monetários são R \$ 20.531,00/dia.

Comparando o consumo de energia elétrica da regra dos AG's com a do CCO, a redução é de 24\% (1.119kW.h dos AG's versus 1.473kW.h do CCO) no horário de ponta, que é o de tarifa mais elevada, resultando em $\mathrm{R} \$ 209,23 /$ dia.

O valor da potência consumida é reduzido mais ainda nos cenários 11 e 30 (18.6MW), para $29 \%$, em relação aos $26.216 \mathrm{~kW}$ consumidos na operação do CCO, representando $\mathrm{R} \$ 30.390,00 /$ dia.

Em termos de consumos de energia elétrica nos horários de ponta e fora de ponta, os cenários 11 e 30 apresentam redução de 45\% (R\$151,00/dia) e 35\% (R\$72,57/dia), respectivamente, em relação à regra do CCO. A proporção fica em torno de 1: 1.6 da regra dos AG's em relação à do CCO.

Já comparando-se o cenário 11 , o de menor consumo, com o cenário 18 , que é o de maior consumo de energia elétrica proposto pelos AG's, essa redução nos horários de ponta e fora de ponta são de $28 \%$ e $60 \%$, respectivamente. 


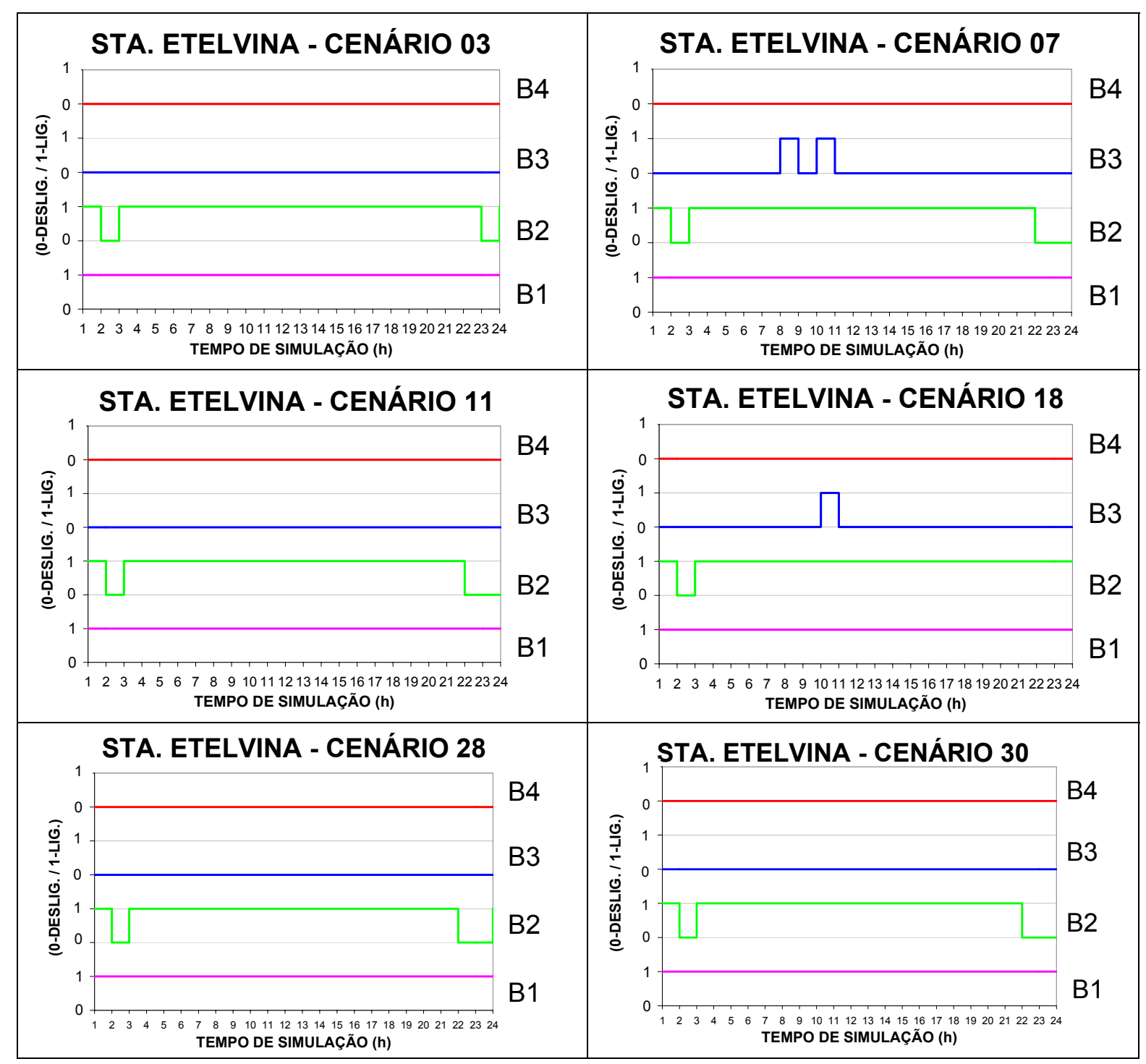

Figura 5.18 - Esquema de operação da Estação Elevatória Santa Etelvina dos cenários otimizados

Observa-se na Figura 5.18, que na operação da Estação Elevatória Santa Etelvina dentre os cenários em análise, a bomba B1 está ligada nas 24h. A bomba B2 tem operação idêntica nos cenários $07,11,28$ e 30, tendo mais um acionamento no cenário 03 e mais três no cenário 18. A bomba B3 só é ligada nos cenários 07 e 18. A potência consumida pela Estação Elevatória Santa Etelvina representa em termos de percentual, um valor de $52 \%$ da potência 
total consumida para os cenários de menor custo, que são o 11 e o 30, e 45\% para o cenário 18 , o de maior custo.

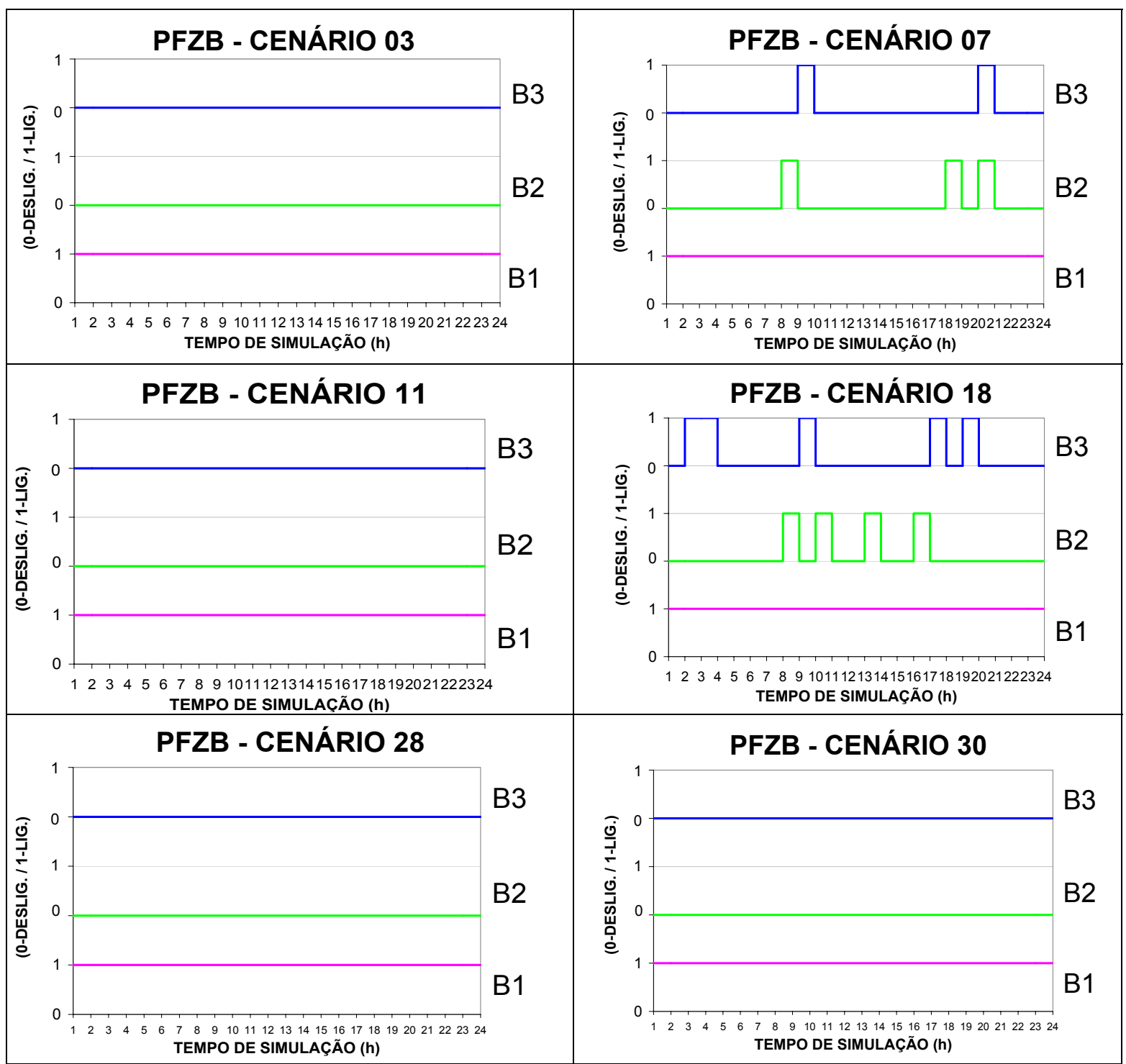

Figura 5.19 - Esquema de operação do Booster Passagem Funda Zona Baixa dos cenários otimizados

No Booster Passagem Funda Zona Baixa, apenas os cenários 07 e 18 apresentam esquema operacional diferenciado dos demais cenários em análise, de acordo com a Figura 5.19. No funcionamento do Booster Passagem Funda Zona Baixa, é necessário o 
funcionamento de apenas uma bomba para atender às demandas do reservatório abastecido pelo booster, ou seja, o acionamento da B2 e B3 nos cenários 07 e 18 se deve pela atuação da mutação, que tem PMUT de 10\%, e não por haver necessidade real de acionamento não sendo, portanto, bons esquemas operacionais. O Booster Passagem Funda Zona Baixa representa $51 \%$ da potência consumida no cenário 18 que é o mais dispendioso, e $48 \%$ nos cenários 11 e 30 , que são os de menor custo.

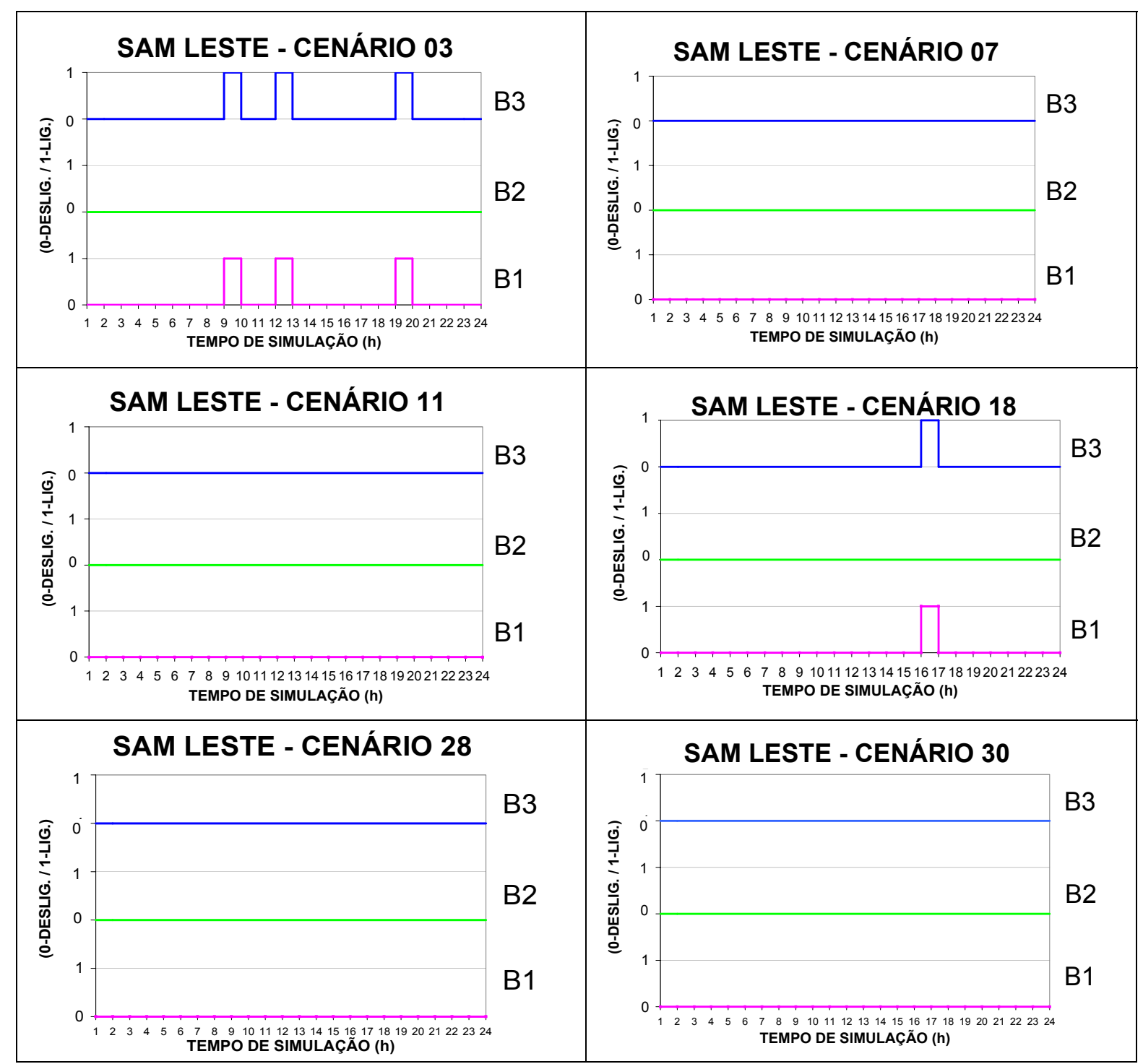

Figura 5.20 - Esquema de operação do Booster SAM Leste dos cenários otimizados. 
A Figura 5.20 mostra que somente nos cenários 03 e 18, o Booster SAM Leste opera. No cenário 03, a potência consumida do Booster SAM Leste é da ordem de $12 \%$, isto é, $2.652 \mathrm{~kW}$. No cenário 18 , sua operação representa apenas $4 \%$ da potência total consumida no sistema, sendo provavelmente influenciado pela PMUT de $10 \%$, já que ocorre somente um acionamento ao longo do período simulado.

$\mathrm{Na}$ regra do $\mathrm{CCO}$, a operação do Booster SAM Leste representa $40 \%$ de toda a energia consumida em termos de potência pelo Sistema SAM Leste, ou seja, 10.608kW.

Os Reservatórios Itaim e Itaquaquecetuba são abastecidos pelo Booster SAM Leste, como pode ser observado nas operações representadas pelas Figuras 5.13 e 5.14. A estratégia proposta pelos AG's é da adução por gravidade e os reservatórios conseguem atender às suas demandas locais, mesmo que com uma operação mais difícil, como é a do Reservatório Itaquaquecetuba.

Nas simulações feitas no Epanet 2.0, em período estendido, com as regras propostas pelos AG's, pode-se observar que a pressão no nó imediatamente a jusante do Booster SAM Leste (ver Figura 4.1), é de 39m em média. Neste nó, as vazões de adução para os Reservatórios Itaim e Itaquaquecetuba se dividem segundo as demandas médias de cada um. Com o Booster SAM Leste fora de operação nas $24 \mathrm{~h}$, o desnível geométrico a ser vencido do recalque deste nó, até a entrada do Reservatório Itaquaquecetuba, que é a condição mais desfavorável, é de $24 \mathrm{~m}$. Considerando as perdas de carga localizadas e distribuídas num total de $8 \mathrm{~m}$, sobram ainda $7 \mathrm{~m}$ de pressão para aduzir a água.

Apesar de as condições serem diferentes da operação deste booster praticada pelo CCO, o modelo Epanet 2.0 (ROSSMAN, 2000), garante que o abastecimento dos Reservatórios Itaim e Itaquaquecetuba, com o Booster SAM Leste fora de operação é viável, a menos de considerações mais precisas de modelagem, que poderiam ser medidas com mais 
confiabilidade, como os coeficientes de rugosidade, cotas levantadas em campo dos medidores de pressão, adutoras e nós de conexão entre as linhas de adução, diâmetros, etc., pois estes dados foram obtidos da base de dados cadastrais operacionais da Sabesp, e os coeficientes de rugosidades foram estimados por tentativa e erro na fase de calibração, de forma a reproduzir as pressões do SCOA nos nós a montante das válvulas de controle de vazão.

O CCO opera pelo menos duas bombas durante $12 \mathrm{~h}$ ao longo das $24 \mathrm{~h}$ no dia considerado para simulação, e manobra a adução aos reservatórios por gravidade somente entre as 6:00h e 14:00h do dia 05/05/2002 e da 01:00h às 6:00h do dia 06/05/2002.

Por mais próxima que tenha sido a calibração do modelo hidráulico do SAM Leste, a operação real da rede é diferente, e considerações acerca de coeficientes de rugosidade, cotas dos medidores de pressão ou dados cadastrais não atualizados, favorecem disparidades entre as soluções propostas e a operação real, registrada no dia típico de simulação.

Apenas os dados de coeficientes de rugosidade aparecem como sendo o diferencial entre as duas operações, pois na tentativa de reproduzir a operação do SCOA no dia escolhido, os referidos coeficientes podem ter sido mais favoráveis que a situação real deste trecho, entre o Booster SAM Leste e os Reservatórios Itaim e Itaquaquecetuba.

Os demais dados de cotas, diâmetros das adutoras e acessórios estão compatíveis com os dados cadastrais e informações da operação da rede. 


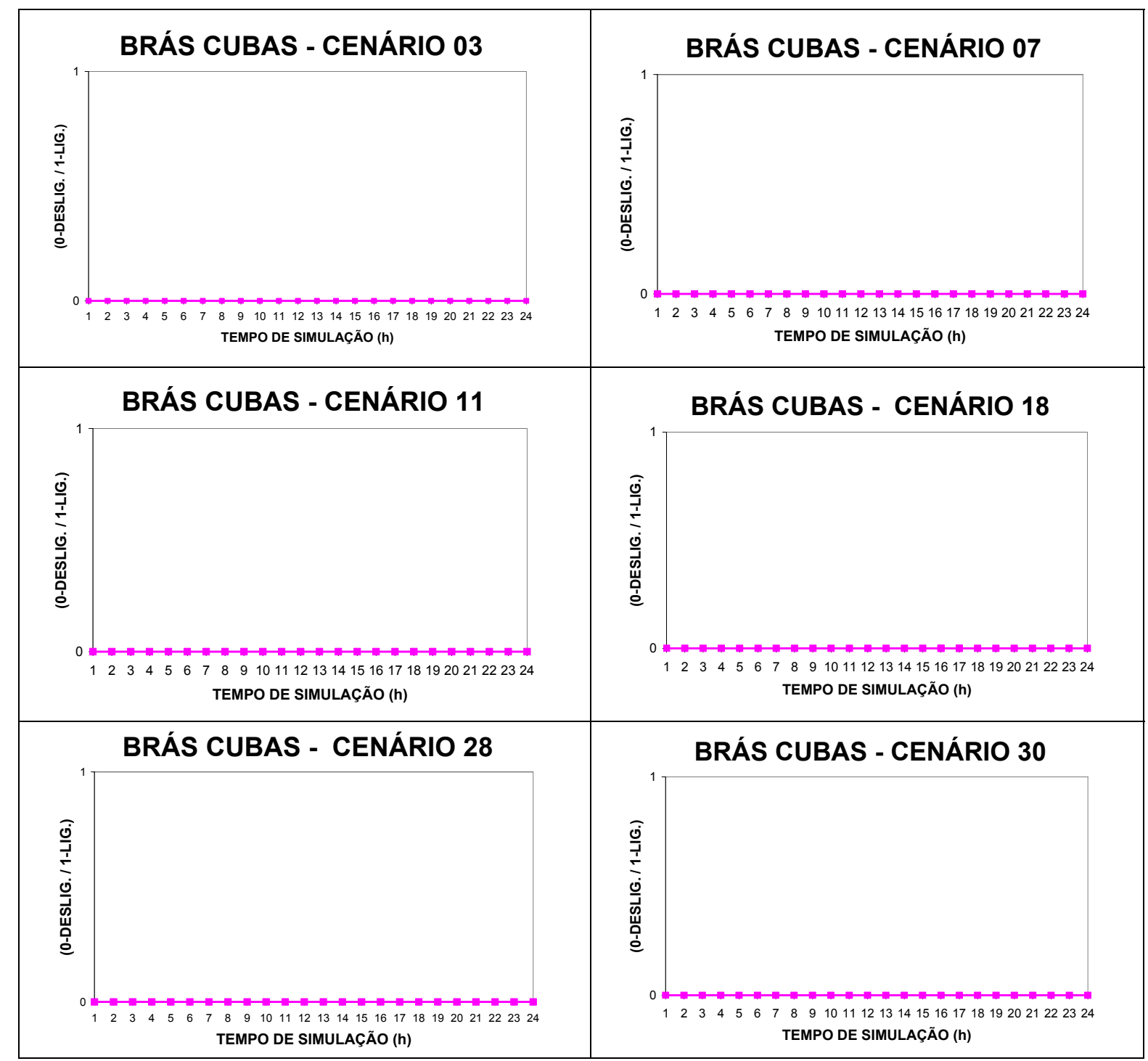

Figura 5.21 - Esquema de operação do Booster Brás Cubas dos cenários otimizados

A Figura 5.21 mostra que o Booster Brás Cubas fica fora e operação todo o período em todos os cenários. Na regra do $\mathrm{CCO}$ a situação operacional é idêntica. Este fato ocorreu porque este booster só opera em dias quentes e de alto consumo de água, ou quando eventualmente o reservatório apresenta redução de nível mais acentuado. O Reservatório Brás Cubas é abastecido por gravidade quando o booster está fora de operação e atendeu as demandas do setor conforme apresentado nas estratégias operacionais da Figura 5.8. 
Como o Booster Brás Cubas tem uma potência elevada (600cv ou $442 \mathrm{~kW})$, seu acionamento implica em um consumo de energia elevado, sendo somente acionado quando o Reservatório Brás Cubas é mais solicitado.

A Tabela 5.5 resume, sinteticamente, a otimização proposta pelos AG's, descrita neste capítulo para os cenários analisados.

Tabela 5.5 - Resumo final da otimização via AG's do SAM Leste

\begin{tabular}{|c|c|c|c|c|c|c|c|c|c|c|c|}
\hline \multicolumn{12}{|c|}{ CENÁRIOS OTIMIZADOS DA OPERAÇÃO DO SAM LESTE VIA AG'S } \\
\hline cenário & PESO & $\begin{array}{c}\text { Nível } \\
\text { inicial de } \\
\text { operação } \\
\text { (\%) }\end{array}$ & $\begin{array}{c}\text { PCRUZ } \\
\text { (\%) }\end{array}$ & $\begin{array}{l}P M U T \\
\text { (\%) }\end{array}$ & PopSize & Iger & $\begin{array}{c}\text { CustoEE } \\
\text { (adim.) }\end{array}$ & $\begin{array}{c}\text { IndicePot } \\
\text { AG/CCO } \\
\text { (\%) }\end{array}$ & $\begin{array}{l}\text { Indice de } \\
\text { Amplitude } \\
\text { de vazão } \\
\text { (\%) }\end{array}$ & $\begin{array}{c}\text { Indice } \\
\text { Manobra } \\
\text { AG/CCO } \\
(\%)\end{array}$ & $\begin{array}{c}\text { I.O.N_OR } \\
\text { MÉDIO } \\
\text { (\%) }\end{array}$ \\
\hline 3 & TIPO 2 & 90 & 30 & 0,2 & 10 & 20 & 0,17 & 83 & 54 & 195 & 102 \\
\hline 7 & TIPO 3 & 90 & 30 & 10 & 10 & 400 & 0,24 & 79 & 63 & 202 & 88 \\
\hline 11 & TIPO 3 & 90 & 30 & 0,5 & 200 & 40 & 0,21 & 71 & 41 & 59 & 89 \\
\hline 18 & TIPO 1 & 90 & 50 & 10 & 10 & 20 & 0,047 & 90 & 57 & 172 & 103 \\
\hline 28 & TIPO 2 & 70 & 80 & 1 & 200 & 40 & 0,14 & 72 & 45 & 65 & 100 \\
\hline 30 & NÃO & 100 & 80 & 0,2 & 200 & 400 & 0,35 & 71 & 41 & 61 & 89 \\
\hline \multicolumn{7}{|c|}{ MÉDIA } & 0,19 & 78 & 50 & 126 & 95 \\
\hline
\end{tabular}

Na Tabela 5.5, são apresentados os valores médios dos custos adimensionais, índices ION_OR, INDICEPOT, INDICEMANOBRA e de amplitude máxima de vazões, considerando os seis cenários analisados neste capítulo.

O CustoEE, custo adimensional de energia elétrica é de 0.19 em média, significando que a operação proposta pelos AG's para o SAM Leste está em um patamar próximo da realidade operacional da área de estudo, pela quantidade de bombas acionadas na estratégia dos AG’s em relação ao praticado pelo CCO.

Quanto mais bombas acionadas, o custo real é mais próximo do custo máximo, obtendo-se então da equação 4.5 , valores mais próximos de zero ( 1 menos este percentual) e quanto menos acionamentos, menor o custo real. Assim, o CustoEE distancia-se de zero mostrando que, se o modelo fornecesse uma operação de maior custo, este valor estaria 
próximo de zero, mas como está em 0.19 , a otimização proposta pelos AG's contempla uma operação otimizada e viável, para o SAM Leste.

O consumo de energia em termos de potência é em média, de $78 \%$ daquela consumida na operação feita pelo $\mathrm{CCO}$, isto é uma redução média de $22 \%$ na potência consumida proposta na regra dos AG's, indicando que as estratégias operacionais praticadas pelo CCO devem ser revistas, de forma a melhorar o desempenho do SAM Leste, em termos de economia de energia elétrica consumida pelos boosters e estações elevatórias.

Em termos monetários, esta redução implica em uma economia diária média de $\mathrm{R} \$ 25.750,00$ na potência consumida no SAM Leste.

As estratégias propostas nos seis cenários levaram a um índice de manobra médio de $126 \%$, isto é $26 \%$ a mais em média, em relação às regras de manobras praticadas pelo CCO. Isto ocorreu pelo fato de que nos cenários com PMUT de 10\%, ocorreram muitos acionamentos das válvulas, decorrentes da variabilidade das vazões de entrada dos reservatórios. É uma desvantagem das altas probabilidades de mutação, que introduz muita perturbação aleatória nas soluções, levando o AG a ter maior dificuldade de buscar por boas soluções.

As vazões de entrada nos reservatórios, fornecidas pelos AG's como variáveis de decisão real, têm seu índice médio de amplitude da ordem de 50\%. Este valor é considerado aceitável, visto toda a dinâmica envolvida na operação dos reservatórios e os efeitos que, obviamente, a decisão do modelo acerca destas variáveis impacta, na sustentabilidade da rede no atendimento às suas demandas.

De todo SAM Leste, observa-se que, na média, os reservatórios oscilam os níveis $95 \%$, valor este considerado bom, já que é um valor médio entre nove reservatórios, das mais diversas características e limitações, físicas e operacionais, que não violam seus limites operacionais e atendem às suas demandas setoriais. 
Dentre os cenários analisados, o modelo otimizador propõe o cenário 11 , como o de melhor cenário de otimização pelos AG's, dentre os cenários analisados. Os parâmetros de AG's de 30\% de PCRUZ, 0.5\% de PMUT, 90\% de nível inicial de operação e utilização de pesos tipo 3, em uma população de 200 indivíduos para 40 gerações, corroboraram para seu desempenho.

Vale ressaltar que o cenário 30 também tem bom desempenho. Não utiliza nenhuma combinação de pesos, tem uma PMUT de $0.2 \%$, a mesma população, mas com 400 gerações desenvolvidas, PCRUZ de $80 \%$ e $100 \%$ de reservação inicialmente.

Observa-se que, para uma otimização com mais tempo para simulação, em termos de operação no dia-dia, a configuração do cenário 30 é uma boa opção.

Para uma otimização com pouco tempo para verificações e simulações, o cenário 11 retrata bem as condições operacionais mais próximas do dia-dia e em tempo real.

\subsection{TEMPO DE PROCESSAMENTO COMPUTACIONAL DOS CENÁRIOS DE OTIMIZAÇÃO}

Com relação ao tempo de processamento gasto nos diversos cenários de otimização, os tempos que competem à simulação do Epanet 2.0 (ROSSMAN, 2000), interface e à otimização dos AG's foram variados. Foi utilizado nas simulações, um computador pessoal com microprocessador tipo Pentium 4 com $2.2 \mathrm{GHz}$ de velocidade de processamento e $352 \mathrm{MB}$ de memória RAM. Dentre as diversas configurações, foram obtidos valores médios de tempo de processamento para o modelo simulador Epanet 2.0 (ROSSMAN, 2000), as interfaces e o otimizador. 
O Epanet 2.0 (ROSSMAN, 2000), e sua interface para as configurações com 10 indivíduos e 20 gerações demoram em média cerca de 8 minutos, em 9 minutos totais de otimização sem aplicação de pesos, sendo 1 minuto gasto com os AG's. Aplicando pesos, a otimização total dura cerca de 12 minutos, sendo 10 minutos gastos pelo Epanet 2.0 (ROSSMAN, 2000) e os 2 minutos restantes utilizados pelos AG's. Vale ressaltar que estes tempos são uma média entre os tempos gastos nas otimizações, dentre os diferentes níveis iniciais de operação, PMUT e PCRUZ utilizados.

Na configuração com 10 indivíduos em 400 gerações, o tempo total gasto em média na otimização foi de aproximadamente 2 horas, sendo cerca de 1 h e 40 minutos gastos no simulador hidráulico e os 20 minutos restantes, gastos nos AG's.

Para a otimização com 200 indivíduos e 40 gerações, o tempo médio é de 3 horas e 20 minutos de otimização completa (simulador+otimizador). O Epanet 2.0 (ROSSMAN, 2000) gasta deste total, cerca de 2 horas e o tempo restante de 1 hora e 20 minutos é gasto pelo AG.

De todas estas as configurações de processamento, tanto a interface do simulador hidráulico quanto a interface com o banco de dados e os arquivos de resultados não dura mais que décimos de segundos cada, e por isso sua medida não é de comentário significativo.

A natureza complexa do SAM Leste também corrobora para que o modelo simulador tenha seu desempenho de velocidade de simulação comprometido, implicando também na demora da definição da solução ótima e no desempenho total do modelo de otimização. Quanto mais restritiva a configuração de simulação quanto à carga inicial, maior a demora na simulação hidráulica. Os resultados de todas as simulações estão em formato digital no Anexo 4. 


\section{CONCLUSÕES}

A proposta desta tese foi verificar a utilização dos AG's para otimizar em tempo real, a operação dos reservatórios e minimizar os custos de consumo de energia elétrica pelos boosters do SAM Leste.

Assim, com base nos resultados das simulações apresentados no capítulo anterior e o acima exposto, além de toda a experiência adquirida durante o desenvolvimento da tese, podese concluir o seguinte:

Nos seis cenários escolhidos, o cenário 11 foi o que teve melhor desempenho em termos de qualidade dos resultados obtidos, e o pior foi o cenário 07. As diferenças entre eles foram o tamanho da população, PMUT e o número de gerações, pois a probabilidade de cruzamento de $30 \%$, a combinação de pesos tipo 3 e o nível inicial de operação em $90 \%$ foram iguais para os dois cenários.

Com relação aos valores médios apresentados na Tabela 5.5, considerando os seis cenários analisados, a operação otimizada do SAM Leste, pelos AG's, tem, em termos de custos adimensionais, o valor médio de 0.19 . Conclui-se que é um valor aceitável, e próximo à realidade operacional do SAM Leste, pois se fosse próximo de zero, estaria indicando uma estratégia com muitos equipamentos em operação e consequentemente, grande consumo de energia elétrica.

Em termos de potência utilizada pelas bombas dos boosters e estações elevatórias, o (INDICEPOT), o AG apresenta o valor médio de $78 \%$, em relação à potência consumida na operação do CCO. Significa uma redução de $22 \%$ de potência $(\mathrm{kW})$ consumida pelas bombas no período simulado da Sabesp, ou $\mathrm{R} \$ 25.750,00 /$ dia, indicando que o esquema operacional praticado pode ser mais eficiente e de menor custo. 
O índice médio de amplitude de vazões entre os seis cenários é de $50 \%$, também considerado bom se observadas as particularidades e a dinâmica de operação de cada setor do SAM Leste.

O índice de oscilação de nível apresentado na Tabela 5.5 é, em média, 95\% para os reservatórios locais, indicando que, na média, os reservatórios do SAM Leste são controláveis, operam dentro de seus limites operacionais no atendimento às demandas e também, garantindo a capacidade de armazenamento dos reservatórios.

O modelo de otimização mostra melhora em seu desempenho, se forem mantidas mais soluções fora do processo de cruzamento com probabilidade de cruzamento de $30 \%$, isto é, boas soluções permanecerem intocadas na população, contribuindo no processo evolutivo ao longo das gerações.

\subsection{CONSIDERAÇÕES FINAIS}

Alguns dados cadastrais necessários para a modelagem não estavam disponíveis na Sabesp, levando a simplificações no modelo hidráulico. Outros dados são pouco confiáveis, prejudicando o desenvolvimento dos modelos simulador e otimizador.

A escolha dos dados e a sua qualidade devem ser rigorosas, fornecendo subsídios para atender aos objetivos do trabalho e contribuir com o êxito dos resultados.

A fase de calibração e validação do modelo hidráulico foi muito importante, pois através dela foi possível ter uma visão mais crítica do SAM Leste em termos de suas limitações de topologia, dimensionamento e capacidade de atendimento às demandas e constatar que este sistema era controlável e que a utilização de um modelo otimizador, contribuiria para melhorar a eficiência da operação e reduzir os custos de energia elétrica. 
O modelo Epanet 2.0 (ROSSMAN, 2000), utilizado na simulação hidráulica e a toolkit utilizada na interface com o otimizador são bons, mas confusos na sua implementação, principalmente para quem tem pouca experiência com simuladores e programação computacional.

As maiores dificuldades encontradas foram quanto ao entendimento do procedimento de simulação do modelo Epanet e a formatação em termos de programação computacional da toolkit na interface com o modelo de otimização. Tarefas mais complexas que surgiram com o decorrer do desenvolvimento do modelo otimizador, como operação do by-pass em conjunto com boosters, por exemplo, não foi possível implementar.

Verificou-se que, na definição dos níveis iniciais de operação dos reservatórios era necessária uma sensibilidade que só foi adquirida com muitos erros e acertos.

Depois de definidos os níveis iniciais de operação dos reservatórios, verificou-se já com o modelo otimizador sendo testado, que estes níveis têm forte impacto no desempenho do modelo de otimização quanto à geração soluções viáveis, e os melhores resultados foram obtidos com $90 \%$ de carga inicial de operação.

No caso da continuidade da otimização para um segundo dia ou mais dias (48h ou mais em vez de apenas 24h), a expectativa seria que, partindo da solução ótima definida para as primeiras $24 \mathrm{~h}$, o modelo teria melhor desempenho tanto na busca pela nova solução operacional do segundo dia, quanto na velocidade de convergência, auxiliando na tomada de decisão da operação futura, no caso de manutenção na rede ou manobras alternativas na rede.

Estes últimos temas valem como sugestões para outros trabalhos, pois estas situações de operação e alteração na topologia da rede devem ser previstas, tanto no modelo de simulação hidráulica quanto no modelo otimizador.

A definição do tamanho da população a ser utilizada no modelo de otimização foi um processo de amadurecimento. Verificou-se que além de influenciar na velocidade de 
processamento dos AG's, o tamanho mais adequado deve ser aquele que dê aos AG's diversidade de opções na busca qualitativa por boas soluções, mas também velocidade para evitar perda de tempo na obtenção da solução ótima.

Recomenda-se avaliar cuidadosamente o problema a ser investigado e os objetivos a serem alcançados. O tamanho ideal depende da dimensão do problema, da quantidade de variáveis de decisão, complexidade da rede e do tempo disponível para se obter a solução ótima.

Como operador de seleção, foram utilizados a roleta que é o mais amplamente utilizado e o torneio, sendo este o escolhido por ser mais eficiente que a roleta na escolha das melhores soluções (DEB, 2000; REIS; AKUTSU, 2002; AHMED; SARMA, 2004), pois entre duas soluções escolhidas aleatoriamente da população, é sempre escolhida a melhor. Foi utilizada a seleção por elitismo também, impondo-se ao AG que fossem mantidas na população, sempre as duas melhores soluções, sem que estas sofressem qualquer modificação, ainda que participem e contribuam nos processos de cruzamento e mutação.

Em uma população de 10 indivíduos, esta imposição elitista é bastante influente, mas em populações maiores, foi um artifício bastante útil, prevenindo que boas soluções não se perdessem no processo evolutivo. Por isso a escolha do tamanho da população requer cuidado, tendo-se sempre em mente o objetivo a ser alcançado e a qualidade das soluções e a velocidade em que elas devem ser produzidas.

Os operadores genéticos de cruzamento e mutação também tiveram sua contribuição fundamental na qualidade dos resultados aqui apresentados.

Observou-se que neste problema, probabilidades baixas de cruzamento (30\%) produziram melhores resultados na otimização da operação que as probabilidades mais altas (80\%). 
O operador mutação é uma ferramenta poderosa que pode ajudar e também atrapalhar. Observou-se que probabilidades de mutação muito baixas $(0.2 \%)$ não dão chance ao AG de pesquisar outros pontos do espaço de soluções. Em compensação, probabilidades mais altas $(10 \%)$ acabam por perturbar a busca e ser danosa a soluções que poderiam ter melhor desempenho a menos da mutação de um gene.

A política de pesos aplicada aqui em diversas combinações, no sentido de direcionar a busca no espaço de soluções viáveis, teve papel auxiliar aos AG's. As simulações mostraram que o AG é mais sensível ao tamanho da população e aos operadores genéticos de cruzamento e mutação, do que aos pesos.

A escolha da combinação mais apropriada a aplicar é uma tarefa longe do trivial, pois são infinitas as combinações e os resultados decorrentes dela.

Segundo Deb (2000) e Ahmed e Sarma (2004), a maior dificuldade na utilização de funções de penalidades é encontrar os parâmetros de penalidade mais adequados para guiar a busca dos AG's até a combinação ótima.

O número de gerações a desenvolver mostrou se não menos importante no processo de otimização. O AG fundamentalmente necessita de um período de evolução para definir e convergir para boas soluções. Neste trabalho, observou-se que muitas gerações desenvolvidas, sem uma boa estratégia de otimização não ajudam muito. Em várias situações, observou-se convergência prematura tanto em poucas gerações, quanto em 2.000 gerações, produzindo soluções viáveis, mas nem sempre retratando boa opção operacional.

Para utilização dos AG's em tempo real, há que se levar em consideração os parâmetros a aplicar relativos ao tamanho da população, probabilidades de cruzamento, de mutação e gerações a desenvolver. 
Os AG's são lentos em seu processo de escolha da solução ótima, assim se combinados com heurísticas de busca local serão mais eficientes que o AG puro aqui aplicado, sendo mais eficiente, portanto, na aplicação em tempo real.

Apesar de ser lento na obtenção da solução ótima, os AG's mais uma vez se mostram robustos e confiáveis, fornecendo não somente uma solução ótima, mas conforme a necessidade de sua aplicação, com boas escolhas em seus parâmetros de otimização e com poucas gerações, podem fornecer boas soluções que indiquem a conduta a seguir.

Atendendo ao objetivo principal proposto, os AG's apresentaram bom desempenho com relação à qualidade das soluções e às regras operacionais propostas, para um string extenso de 480 variáveis, e considerando que o SAM Leste é um sistema grande, complexo e com muitas limitações e restrições operacionais.

Como recomendações e sugestões de pesquisas futuras, coloca-se mais uma vez que a definição do problema a ser tratado, as variáveis e condições de contorno envolvidas, devem ser analisadas e escolhidas com cuidado e rigor, de forma a evitar problemas futuros.

A utilização de políticas de penalização com pesos deve ser verificada e aplicada conforme as características de cada problema e não aplicar uma técnica ou formulação desenvolvida para um problema em outro de características diferentes. A literatura apresenta muitas pesquisas com estes problemas e só definir a melhor política de pesos e se utilizá-los já são outros trabalhos a desenvolver. Criar um modelo genérico de otimização com AG's para operação em tempo real, mostra-se como um tema interessante a ser investigado mais profundamente.

O aperfeiçoamento de eficiência dos AG's, com a utilização de métodos híbridos de heurísticas ou meta-heurísticas deve ser investigado, mas sem que se torne uma combinação difícil de entender, pois a maior vantagem dos AG's é sua simplicidade. 
Os grandes sistemas fazem parte do dia-dia dos engenheiros e gestores de sistemas de abastecimento de água, e a complexidade é inerente a estes sistemas. Modelos de simulação e de otimização devem ser mais simplistas, na interface com os operadores, que são céticos quanto à eficiência destes modelos e sua confiabilidade, e sendo mais uma ferramenta que um problema, para os engenheiros e gestores destes sistemas.

Há muito ainda que se fazer, para estabelecer a ligação entre o mundo real e sua dinâmica, na busca de ferramentas que ajudem a solucionar os problemas quantitativos e qualitativos, do gerenciamento dos recursos hídricos e naturais de forma geral

Não se pretendeu aqui, solucionar todos os problemas inerentes à operação dos sistemas adutores e de distribuição de água, mas sim fornecer uma ferramenta, que associada a um sistema de monitoramento SCADA e a simuladores hidráulicos, otimizasse com os Algoritmos Genéticos a operação de um sistema real, grande, complexo e limitado, auxiliando os operadores e gestores na tomada de decisão, face aos cenários de operação diários e aos problemas que se apresentam diante do corpo técnico, desta área da Engenharia Hidráulica. 


\section{REFERÊNCIAS BIBLIOGRÁFICAS}

AHMED, J.A.; SARMA, A.K. Genetic algorithms for optimal operating policy of a multipurpose reservoir. Water Resources Management, p. 1-17, 2004.

BANDEIRANTE 10 JAN. 2003 Tarifas para o fornecimento de energia elétrica. Disponível em: <http://www.dim.com.br/bandeirante/site/desenvolvimento/default.asp?Sec=16\& SubSec $=21>$. Acesso em: 10 jan. 2003.

BARR, R. S.; GOLDEN, B.L.; KELLY, J.P.; RESENDE, M.G.C.; STEWART, W.R. Design and reporting on computational experiments with heuristic methods. Postscript, Dallas, TX, June, 1995.

BISCOS, C. et al. Optimal operation of a potable water distribution network. Water Science \& Technology. v. 46, n.9, 2002.

BORGES, V. M. N. A. Acoplamento de um modelo de previsão de demanda de água a um modelo simulador em tempo real, um estudo de caso: sistema adutor metropolitano de São Paulo. 2003, 205p. Dissertação (Mestrado em Engenharia Hidráulica) - Escola Politécnica da Universidade de São Paulo. São Paulo, 2003.

BRION, L.M.; MAYS, L.W. Methodology for optimal operation of pumping stations in water distribution systems. Journal of Hidraulic Engineering. v. 117, n.11, p. 1551 - 1569, 1991. 
CARRIJO, I. B. Extração de regras operacionais ótimas de sistemas de distribuição de água através de algoritmos genéticos multiobjetivo e aprendizado de máquina. 2004. 217p. Tese (Doutorado em Hidráulica e Saneamento) - Escola de Engenharia de São Carlos, Universidade de São Paulo. São Carlos, 2004.

CASTILlO, L.; GONZÁLEZ, A. Distribution network optimization: finding the most economic solution by using genetic algorithms. European Journal of Operational Research. v.108, p. 527-537, 1998.

CHANG, Ni-Bin; WEI, Y.L. Siting recycling drop-off stations in urban area by genetic algorithm-based fuzzy multiobjective nonlinear integer programming modeling. Fuzzy Sets and Systems. v. 114, p. 133-149, 2000.

CIPPARRONE, F.A.M. Otimização do controle operacional de sistemas hidráulicos complexos. 1995. 106f. Tese (Doutorado em Engenharia Elétrica) - Escola Politécnica, Universidade de São Paulo, São Paulo, 1995.

Companhia de Saneamento Básico do Estado de São Paulo (SABESP). Departamento de Desenvolvimento Operacional da Produção. Divisão de Processos de Água. Estudo de Otimização da Reservação do SAM . Revisão 1. São Paulo. 1999. 40f.

Companhia de Saneamento Básico do Estado de São Paulo (SABESP). CADOP. Cadastro de Dados Operacionais. 2003. 
Companhia de Saneamento Básico do Estado de São Paulo (SABESP). SCOA. Banco de dados. Disponível em :<gracione@hotmail.com> . Acesso em 03 jun. 2003.

CUI, Li-Jie; KUCZERA, G. Optimizing urban water supply headworks using probabilistic search methods. Journal of Water Resources Planning and Management. v. 129, n.5, p. 380-387, september, 2003.

DEB, K. An efficient constraint handling method for genetic algorithms. Computer Methods in Applied Mechanics and Engineering. v.186, p.311-338, 2000.

DEB, K. Multi-objective optimization using evolutionary algorithms. Chichester, England, John Wiley \& Sons, Ltda. 2001. 491f.

De SHAETZEN, W.B.F.; SAVIC, D.A.; WALTERS, G.A. A genetic algorithm approach to pump scheduling in water supply systems. Postscript, United Kingdom, 1998.

DIBA, A. et al. Planned operation of large-scale water distribution system. Journal of Water Resources Planning and Management. v. 121, n.3, p. 260-269, may-june, 1995.

DRAPER, A. J. et al. Economic-engineering optimization for California water management. Journal of Water Resources Planning and Management. v. 129, n.3, p. 155-164, may, 2003.

FRANCATO, A. L. Operação multiobjetivo de sistemas urbanos de abastecimento de água. 2002. 179f. Tese (Doutorado em Engenharia Civil) - Faculdade de Engenharia Civil, Universidade de Campinas. Campinas, 2002. 
FUJIWARA, O.; TUNG, H.D. Reliability improvement for water distribution networks through increasing pipe size. Water Resources Research. v.27, n.7, p-1395-1402, july, 1991.

GAMBALE, S.R. Aplicação de algoritmo genético na calibração de redes de água. 2000. 266f. Dissertação (Mestrado) - Escola Politécnica, Universidade de São Paulo. São Paulo, 2000.

GEN, M.; CHENG, R. Genetic algorithms and engineering design. Wiley series in engineering design and automation. New York. John Wiley \& Sons, Inc. 1997. 411f.

GOLDBARG, M.C.; LUNA, H.P.L. Otimização Combinatória e programação Linear: modelos e algoritmos. Rio de Janeiro. Editora Campus. 2000.

GOLDBERG, D.E. Genetic algorithms in search, optimization and machine learning. Massachussets Addison-Wesley Publishing Co. Reading.1987.

GOLDBERG, D.E.; KUO, C. Genetic algorithms in pipeline optimization. Journal of Computing in Civil Engineering. v.1, n. 2, p. 128-141, may, 1987.

GOULTER, I.C.; COALS, A. V. Quantitative approaches to reliability assessment in pipe networks. Journal of Transportation Engineering. v.112, n.3, p. 287-301, may, 1986.

GOULTER, I.C.; BOUCHART, F. Reliability-constrained pipe network model. Journal of Hidraulic Engineering. v.116, n.2, p. 211-229, february, 1990. 
GUPTA, I.; KHANNA, G. P. Genetic algorithm for optimization of water distribution systems. Environmental Modelling \& Software. v.14, p. 437-446, 1999.

HAGUIUDA, C. Publicação eletrônica [mensagem pessoal]. Mensagem recebida por gracione@hotmail.com em 09 abr. 2003.

HAUPT, R.L.; HAUPT, S.E. Practical genetic algorithms. New York. Wiley-Intercience. 1998.

HOLLAND, J. H. Adaptation in natural and artificial systems. MIT Press. 1975. Cambridge, Massachussets.

HALHAL, D.; WALTERS, G.A.; OUAZAR, D.; SAVIC, D.A. Water Network rehabilitation with structured messy genetic algorithms. Journal of Water Resources Planning and Management. v. 123, n.3, p. 137-146, may-june, 1997.

JAMES, R. J. W. Using tabu search to solve the common due date early/tardy machine scheduling problem. Computer Operational Research. v. 24, n.3, p.199-208. Great Britain, 1997.

LABADIE, J. W. Optimal operation of multi-reservoir systems: state-of-art review. Journal of Water Resources Planning and Management. v. 130, n.2, p. 93-111, march-april, 2004.

LAGUNA, M. Tabu search tutorial. In: II ESCUELA DE VERANO LATINO-AMERICANA DE INVESTIGACIÓN OPERATIVA. 1995. 
LEÓN, C.; MANTÍN, S.; ELENA, J. M.; LUQUE, J. EXPLORE - Hybrid expert system for water networks management. Journal of Water Resources Planning and Management. v. 126, n.2, p. 65-74, march-april, 2000.

LI, F.; AGGARWAL, R.K. Fast and accurate power dispatch using a relaxed genetic algorithm and a local gradient technique. Expert Systems with Applications. v.19, p. 159$165,2000$.

LUVIZZOTO JÚNIOR, E. Controle operacional de redes de abastecimento de água auxiliado por computador. 1995. Tese (Doutorado em Engenharia Hidráulica) - Escola Politécnica, Universidade de São Paulo. São Paulo, 1995.

MCCORMICK, G.; POWELL, R.S. Optimal pump scheduling in water supply systems with maximum demand charges. Journal of Water Resources Planning and Management. v. 129, n., p. 372-379, september, 2003.

MEIER, R.W.; BARKDOLL, B.D. Sampling design for network model calibrating using genetic algorithm. Journal of Water Resources Planning and Management. v.126, n.4, p. 245-250, july-august, 2000.

MICHALEWICZ, Z. Genetic algorithms + data structures = evolution programs. New York. Spring-Verlag. 1992. 
MINER JR. W.H.; VALANJUA P.M.; HIRSHMANB S.P.; BROOKSC, A.; POMPHREYC, N. Use of a genetic algorithm for compact stellarator coil design. Nuclear Fusion.v.41, p.1185-1195. September, 2001.

MIRANDA, V.; SRINIVASAN, D.; PROENÇA, L.M. Evolutionary computation in power systems. Eletrical Power \& Energy Systems. v. 20, n.2, p. 89-98, 1998.

MURTAGH, B.A.; SAUNDERS, M.A. Minos 5.1 User's Guide. Technical Report. 1987.

OLIVEIRA, R.; LOUCKS, D.P. Operating rules for multireservoir systems. Water Resources Research, v. 33, n.4, p.839-852. april, 1997.

ORMSBEE, L.E.; LANSEY, K.E. Optimal control of water supply pumping systems. Journal of Water Resources Planning and Management. v.120, n.2, p. 237-252, marchapril,1994.

PEZESHK, S.; HELWEG, O.J.; OLIVER, K.E. Optimal operation of groundwater supply distribution systems. Journal of Water Resources Planning and Management. v.120, n.5, p. 573-585, september-october, 1994.

PORTO, R.L.L. et al. (2003). "Sistema de suporte a decisão para análise de sistemas de recursos hídricos", in Métodos Numéricos em Recursos Hídricos, editado por Silva, R.C.V., Porto Alegre, Brasil, ABRH, pp. 93-240. 
PRASAD, T.D.; PARK, N-S. Multiobjective genetic algorithms for design of water distribution networks. Journal of Water Resources Planning and Management. v.120, n.5, p. 573-585, september-october, 1994.

REIS, L.F.R.; PORTO, R. M. \& CHAUDHRY, F.H. Optimal location of control valves in pipe networks by genetic algorithms. Journal of Water Resources Planning and Management. v.123, n.6, p. 317-326, november-december,1997.

REIS, L.F.R; AKUTSU, J. Estratégias operacionais para sistemas de reservatórios via algoritmos genéticos (AGs). Revista Brasileira de Recursos Hídricos. v.7, n.3, JulhoSetembro, p. 5-17, 2002.

RIBEIRO, C. E. Controle de escoamentos em instalações de condutos forçados. 1985. Tese (Doutorado em Engenharia Hidráulica) - Escola Politécnica, Universidade de São Paulo. Paulo, 1985.

RIBEIRO, G.P. Custos de produção de águas subterrâneas com operação otimizada via algoritmos genéticos para o abastecimento urbano de araraquara/SP. 2000. Dissertação (Mestrado em Engenharia Civil) - Escola de Engenharia de São Carlos, Universidade de São Paulo. São Carlos, 2000.

ROSSMAN, L.A. Epanet 2.0 Users Manual. U.S. Environmental Protection Agency. Cincinnati, Ohio. 2000. 
SAKARYA, B.A.; MAYS, L.W. Optimal operation of water distribution pumps considering water quality. Journal of Water Resources Planning and Management. v.126, n.4, p. 210220, july-august, 1998.

SANTANA,G.C. Otimização da operação de sistemas de água abastecidos por bombeamento e reservatórios de regularização.1992. Tese (Doutorado em Engenharia Civil) - FEEC, Universidade de Campinas. Campinas, 1992.

SAVIC, D.A.; WALTERS, G.A.; SCHWAB, M. Multiobjective genetic algorithm for pumping scheduling in water supply. In: AISB'97. Evolutionary Workshops. Manchester, UK. 1997.

SIMONOVIC, S.P. Last resort algorithms for optimization of water resources systems, Canadian Operational Research Society Bulletin, v.34, n.1, p. 9-19, 2000.

SIMPSON, A. R.; DANDY, G.C.; MURPHY, L.J. Genetic algorithms compared to other technics for pipes optimization. Journal of Water Resources Planning and Management. v.120, n.4, p. 423-443, july-august, 1994.

SMITH, D.K.; WALTERS, G.A. An evolutionary approach for finding optimal trees in undirected networks. European Journal of Operational Research. v.120, p.593-602, 2000.

TARQUIN, A.J.; DOWDY, J. Optimal pump operation in water distribution. Journal of Hidraulic Engineering. v.115, n.2, p. 158-168, 1989. 
TOLSON, B.; MAIER, H.R.; SIMPSON, A.; LENCE, B.J. Genetic algotithms for reliabilitybased optimization of water distribution systems. Journal of Water Resources Planning and Management. v.130, n.1, p. 63-72, january, 2004.

VAN ZYL, J. E.; SAVIC, D. A.; WALTERS, G. A. Operation optimization of water distribution systems using a hybrid genetic algorithm. Journal of Water Resources Planning and Management. v.130, n.2, p. 160-170, march, 2004.

WAGNER, J.M.; SHAMIR, U.; MARKS, D.H. Water distribution reliability: simulation methods. Journal of Water Resources Planning and Management. v.114, n.3, p. 276-294, may, 1988.

WALSKI, T.M. et al. Battle of network models: epilogue. Journal of Water Resources Planning and Management. v.113, n.2, p. 191-203, march, 1987.

WALTERS, G.A; SAVIC, D.A; MORLEY, M.S.; DeSCHAETZEN, W.; ATKINSON, R.M. Calibration of water distribution networks models using genetic algorithms. Poscript. United Kingdom, 1988.

WARDLAW, R; SHARIF, M. Evaluation of genetic algorithms for optimal reservoir system operation. Journal of Water Resources Planning and Management. v.125, n.1, p. 25-33, january-february, 1999.

WATKINS, D.W.; McKINNEY, D.C. Decomposition methods for water resources optimization models with fixed costs. Advances in Water Resources. v.21, p.283-295, 1998. 
WOOD, D.J. User's manual - computer analysis of flow in pipe networks including extended period simulations. University of Kentucky, Lexington. 1981.

WURBS, R.A. Reservoir-system simulation and optimization models. Journal of Water Resources Planning and Management. v.119(4), p.455-472, july-august, 1993.

WU, Z. Y.; SIMPSON, A.R. Competent genetic-evolutionary optimization of water distribution systems. Journal of Computing in Civil Engineering. v.15, n.2, p.89-101, april, 2001.

YEH, W.W.-G. Reservoir management and operation models: a state-of-the-art review. Water Resources Research, v. 21(12), p.1797-1818, february, 1985.

ZAHED, FILHO. K. Previsão de demanda de consumo em tempo real no desenvolvimento operacional de sistemas de distribuição de água. 1990. Tese (Doutorado em Engenharia Hidráulica) - Escola Politécnica, Universidade de São Paulo. São Paulo, 1990. 
ANEXO A 
ANEXO B 
MSN Hotmail - Messagegracione@hotmail.com MSN Home | My MSN

From :

chaguiuda@sabesp.com.br

To :

"gracione ribeiro" < gracione@hotmail.com>

Subject :

Re: informações para tese

Date :

Wed, 9 Apr 2003 15:15:12 -0300

Attachment : SAMLesteDezeJan.xls (25k), BAND2002-571.pdf (74k)

Reply Reply All Forward Delete Put in

Folder...InboxSent MessagesDraftsTrash Candiversosgenetic

algorithmswater supply Printer Friendly Version

Prezada Gracione,

Encaminho as informações solicitadas, referentes às instalações Booster

Alça Leste, Booster Brás Cubas, EEAT Itaquaquecetuba, Passagem Funda e

Santa Etelvina.

Anexo, ainda, o arquivo de tarifas da Bandeirante.

Todas as instalações estão conectadas à rede de $13,8 \mathrm{kV}$, portanto, com

entrada primária em média tensão (tarifação horosazonal azul, A4).

Coloco-me à disposição para esclarecimentos adicionais.

Atenciosamente,

Celso Haguiuda

5683-3229

(See attached file: SAM Leste Dez e Jan.xls)(See attached file:

BAND2002-571.pdf)

"gracione

ribeiro" Para: http://lw11fd.law11.hotmail.msn.com/cgi-

bin/compose? curmbox=F000000001\&a=ba314a720d716968b405d74f051e5c68\&mailto=1\&to=chaguiuda@sab esp.com.br\&msg $=$ MSG1049919748.54\&start $=1263760 \& l e n=105558 \&$ src $=\&$ type $=\mathrm{x}$

<gracione@hotmail cc:

.com> Assunto: informações para tese

21/03/03 08:55

Prezado Sr.

Meu nome é Gracione e sou orientada de doutorado do Prof. Kamel Zahed

Filho,

da Escola Politécnica da USP, que também é engenheiro do Depto. de

Desenvolvimento do Centro de Controle da Sabesp. Meu trabalho é desenvolver 
um modelo de otimização da operação do SAM Leste da RMSP e estava precisando

de alguns dados referentes às bombas instaladas nesse setor do SAM:

consumo,

demandas e tarifas contratadas junto à Eletropaulo e especificações

técnicas

desses equipamentos. Poderia me ajudar? Qual a melhor forma de contato para

obter essas informações? Espero contar com sua ajuda. Grata pela sua

atenção,

Atenciosamente

Eng.a Gracione Ribeiro 
MSN Hotmail - Mensagemgracione@hotmail.com Início | Meu MSN |

De: <chaguiuda@sabesp.com.br>

Enviado: sexta-feira, 21 de janeiro de 2005 11:30:04

Para: "gracione ribeiro" <gracione@hotmail.com>

Cc: rose@sabesp.com.br

Assunto: Re: booster SAM Leste

||Caixa de Entrada

Gracione,

As informações sobre as bombas são as que possuo.

Esclarecimentos podem ser obtidos junto ao CCO, possivelmente com a Rose (Rosmeiry Vicente) 3388-8404 (rose@sabesp.com.br).

Celso

\author{
"gracione \\ ribeiro" Para: chaguiuda@sabesp.com.br \\ <gracione@hotmail cc: \\ .com> Assunto: booster SAM Leste
}

20/01/2005 16:37

\title{
Oi Celso,
}

desculpe amolar tanto ve mas estou recalibrando meu modelo hidráulico com os

dados que vc me passou e lá no booster SAM Leste tá com vazão máxima $7421 / \mathrm{s}$.

O problema é que preciso mandar mais que as três bombas ligadas de acordo com a operação do SCOA do dia que eu estou simulando....é essa vazão mesmo?

De: $<$ rose@sabesp.com.br $>$

Enviado: quarta-feira, 9 de fevereiro de 2005 20:03:20

Para: "gracione ribeiro" <gracione@hotmail.com>

Assunto: Re: informações

||Caixa de Entrada

Anexo: Vazõesdebombasjan_2005.doc (0.06 MB), Bomba060502.xls (0.68 MB)

Olá Gracione,

os dados estão ok.

hidraulicamente não houve nenhuma mudança no sistema, nos 
boosteres indicados (Santa Etelvina, Brás Cubas, Passagem Funda ZB e Sam Leste).

O que houve foi um processo de automação do sistema com modificações na parte elétrica, dentro de um programa de Eficiência Energética vem sendo implementado desde de março de 2003.

Os dados enviados pelo eng. Celso estão corretos.

At.

Rose

"gracione ribeiro" < gracione@hotmail.com>

09/02/2005 13:54

Para: rose@sabesp.com.br

cc:

Assunto: informações

Prezada Sra.

Sou orientada do prof. Kamel Zahed na Poli e estou desenvolvendo uma tese de doutorado com o objetivo de otimizar a operação da Alça Leste.

Entrei em

contato com o Eng. Celso Haguiuda para obter informaçoes sobre as curvas das

bombas dos boosters Sta. Etelvina, Passagem Funda ZonaBaixa,

SAM Leste e

Brás Cubas. Estou trabalhando com dados do dia 06/05/2002 e

segundo ele, os

dados dos equipamentos do arquivo anexo valem até Outubro/2003

e o outro

arquivo é referente à operação. Será que podia confirmar esses

dados, se

fosse possível? Desde já agradeço sua atenção.

Atenciosamente,

Eng. Gracione Ribeiro 


\section{From :}

vmborges@sabesp.com.br

To :

gracione@hotmail.com

CC :

kamelzf@sabesp.com.br

Subject :

SCOA

Date :

Wed, 30 Apr 2003 11:22:29 -0300

Reply Reply All Forward Delete Put in

Folder...InboxSent MessagesDraftsTrash Candiversosgenetic algorithmswater supply Printer Friendly Version

Gracione,

Só para confirmar, os pontos de controle que você tem no Guaianazes é a pressão do Booster - SCOA 09, P03 - sucção (09P03) e nos reservatórios Passsagem Funda ZA e ZB, você tem que controlar os pontos também nos Boosters (093P01 - sucção e 091P01 - recalque).

Até mais,

Viviana 
Autorizo a reprodução e divulgação total ou parcial deste trabalho, por qualquer meio convencional ou eletrônico, para fins de estudo e pesquisa, desde que citada a fonte.

São Paulo, de novembro de 2005. 